\title{
Characterization of groundwater flow and vulnerability assessment of karstic aquifers - Development of a travel time based approach and application to the Tanour and Rasoun spring catchment (Ajloun, NW-Jordan)
}

\author{
Dissertation \\ zur Erlangung des mathematisch-naturwissenschaftlichen Doktorgrades \\ "Doctor rerum naturalium" \\ der Georg-August-Universität Göttingen \\ im Promotionsprogramm Geowissenschaften \\ der Georg-August University School of Science (GAUSS) \\ vorgelegt von \\ Ibraheem Hamdan \\ aus \\ Jordan
}

Göttingen 2016 


\section{Betreuungsausschuss}

Prof. Dr. Martin Sauter

Prof. Dr-Ing. Thomas Ptak

Dr. Bettina Wiegand
Abteilung Angewandte Geologie, Georg-August-Universität Göttingen

Abteilung Angewandte Geologie, Georg-August-Universität Göttingen

Abteilung Angewandte Geologie, Georg-August-Universität Göttingen

\section{Mitglieder der Prüfungskommission}

$\begin{array}{lll}\text { Referent } & \text { Prof. Dr. Martin Sauter } & \begin{array}{l}\text { Abteilung Angewandte Geologie, } \\ \text { Georg-August-Universität Göttingen }\end{array} \\ \text { Korreferent } 1 & \text { Prof. Dr-Ing. Thomas Ptak } & \begin{array}{l}\text { Abteilung Angewandte Geologie, } \\ \text { Georg-August-Universität Göttingen }\end{array} \\ \text { Korreferentin } 2 & \text { Dr. Bettina Wiegand } & \begin{array}{l}\text { Abteilung Angewandte Geologie, } \\ \text { Georg-August-Universität Göttingen }\end{array}\end{array}$

weitere Mitglieder der Prüfungskommission:

Prof. Dr. Heinz Hötzl

Prof. Dr. Hans Ruppert

PD Dr. Chicgoua Noubactep
Institute für Angewandte Geowissenschaften, Karlsruhe Institute für Technologie

Abteilung Sedimentologie und Umweltgeologie, Georg-August-Universität Göttingen

Abteilung Angewandte Geologie, Georg-August-Universität Göttingen

Tag der mündlichen Prüfung: 12.07.2016 


\section{Table of contents}

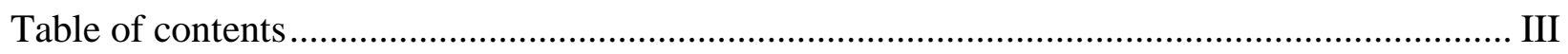

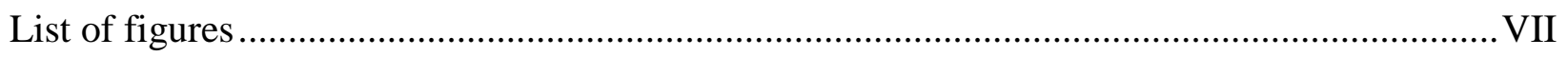

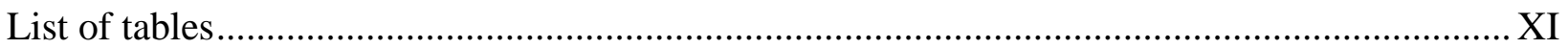

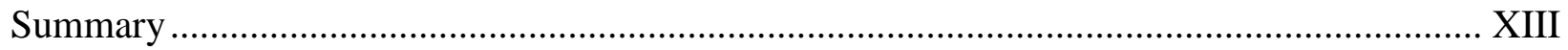

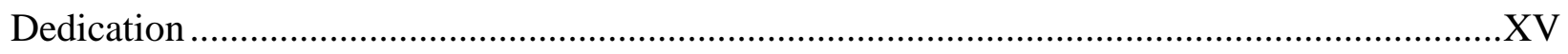

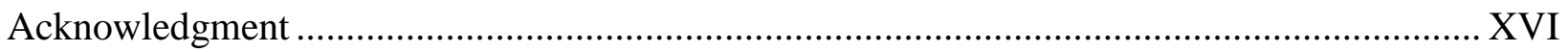

1. Chapter one: Introduction ..................................................................................... 1

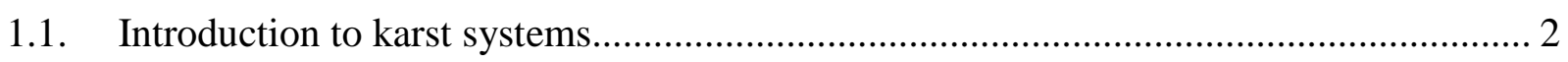

1.1.1. Background and definition of karst systems ............................................................. 2

1.1.2. Characterization of karst aquifers .................................................................... 4

1.2. General overview - water situation in Jordan.......................................................... 7

1.3. Research motivation, challenges, and objectives ......................................................... 10

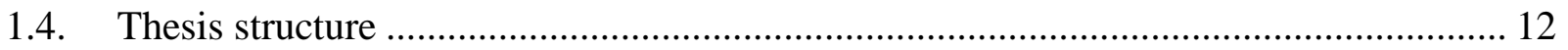

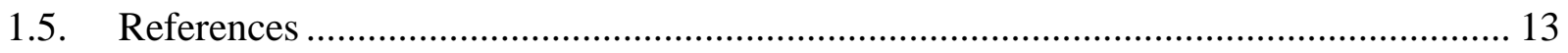

2. Chapter two: Study area description............................................................................... 18

2.1. Geographical location and topography ....................................................................... 19

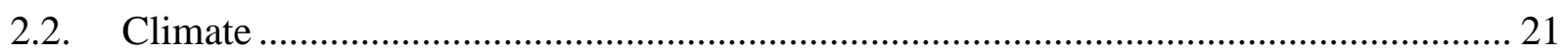

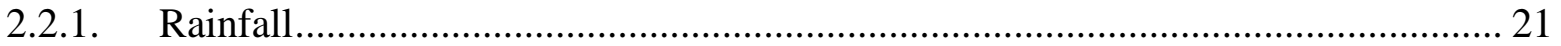

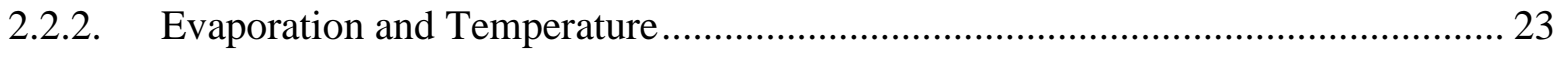

2.3. Land cover classification......................................................................................... 25

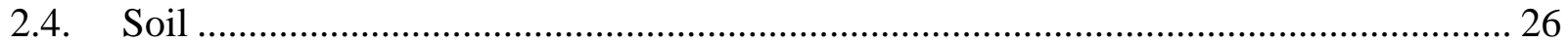

2.5. Tanour and Rasoun spring characteristics..................................................................... 28

2.6. Tanour and Rasoun spring discharge and production ................................................... 31

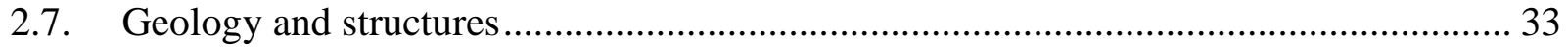

2.7.1. Upper part of the Ajloun Group.............................................................................. 34

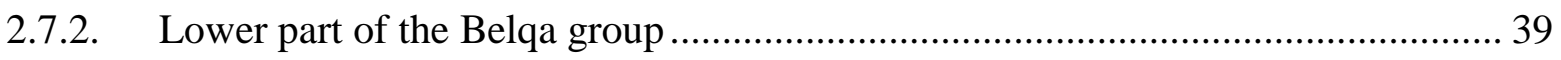

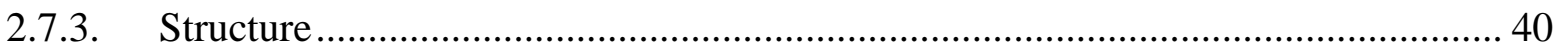

2.7.4. Available karst features within the catchment area .................................................. 41 


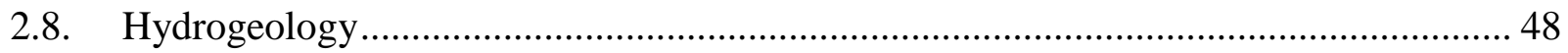

2.8.1. Hydrogeological aquifers within the study area ..................................................... 48

2.8.2. Estimation of hydraulic parameters for saturated zone............................................ 48

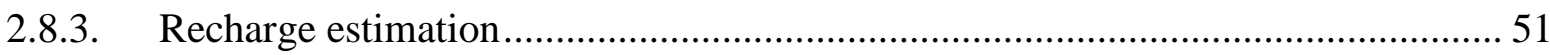

2.9. Developing a 3-D geological model of the study area using ArcGIS and GOCAD

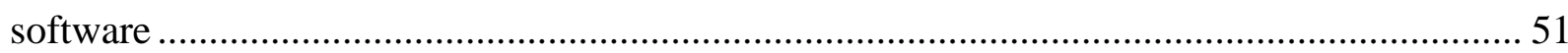

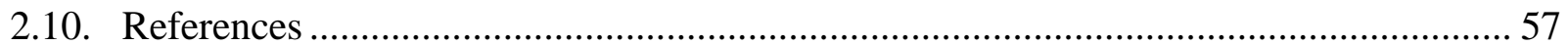

3. Chapter three: Groundwater vulnerability assessment of karst aquifers using a travel time physics-based method, and COP and EPIK intrinsic vulnerability assessment methods .............. 60

3.1. Overview on groundwater vulnerability assessment........................................................ 61

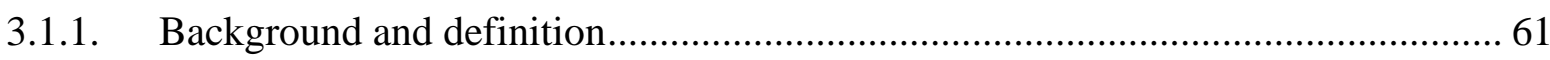

3.1.2. The "European approach" for groundwater vulnerability assessment ...................... 64

3.2. Applying the COP and EPIK intrinsic vulnerability assessment methods for the karstic

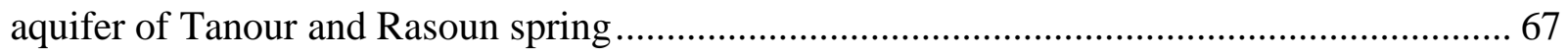

3.2.1. General overview on COP and EPIK vulnerability assessment methods............... 67

3.2.2. Data requirement for COP and EPIC vulnerability assessment methods ................ 68

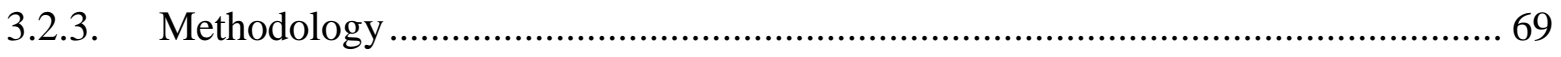

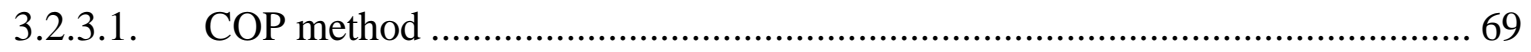

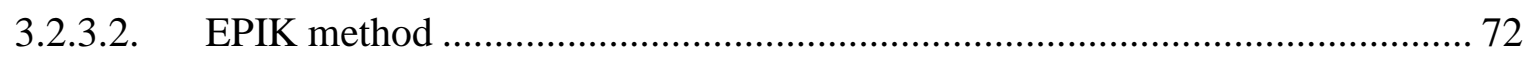

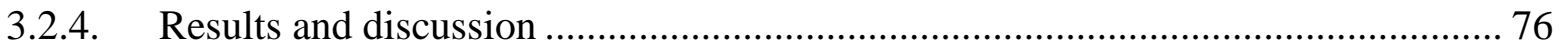

3.2.4.1. COP method factors results .......................................................................... 76

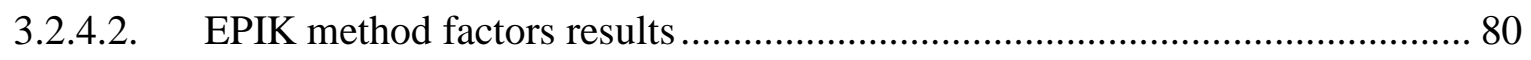

3.2.4.3. Final COP and EPIK vulnerability assessment maps ....................................... 82

3.3. Travel time physics-based groundwater vulnerability assessment for non-point pollution

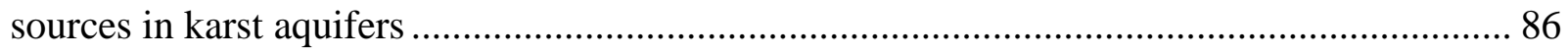

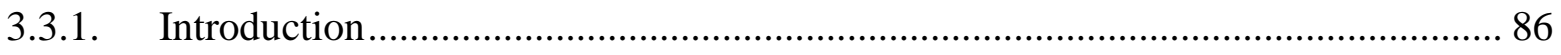

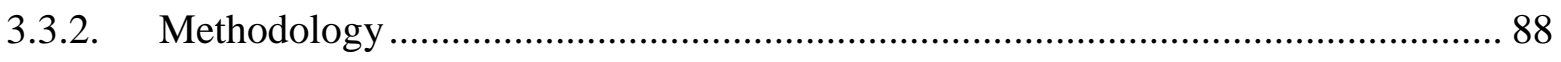

3.3.2.1. Physics-based travel time method .................................................................. 88

3.3.2.2. Hydraulic conductivity estimation of the epikarst zone ................................... 90

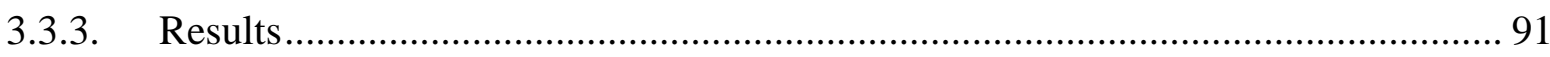

3.3.4. Discussion .......................................................................................................... 94

3.3.4.1. Travel time physics-based method .................................................................... 94 
3.3.4.2. Water travel times and potential sources of pollution within the catchment... 96

3.3.4.3. Travel time physics-based method in comparison with COP and EPK intrinsic vulnerability assessment method ................................................................ 97

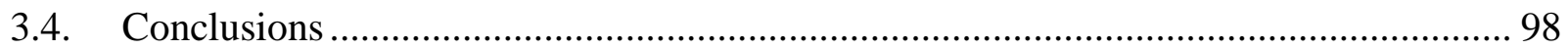

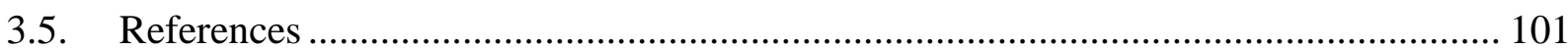

4. Chapter four: Using stable isotopes of oxygen and hydrogen in determining groundwater travel time and springs response to precipitation events in karst aquifers............................. 107

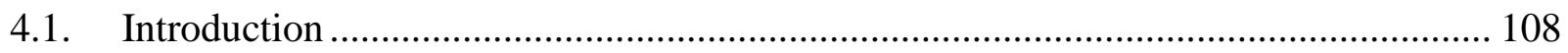

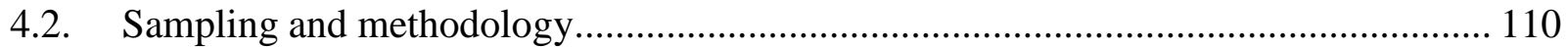

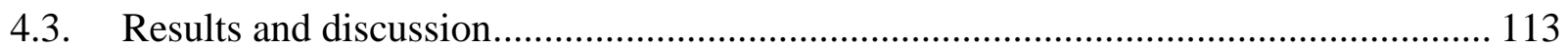

4.3.1. $\quad \delta^{18} \mathrm{O}$ and $\delta^{2} \mathrm{H}$ composition of rain and snow water samples.............................. 113

4.3.2. Tanour spring response to precipitation events using $\delta^{18} \mathrm{O}$ and $\delta^{2} \mathrm{H}$.................. 115

4.3.3. Rasoun spring response to precipitation events using $\delta^{18} \mathrm{O}$ and $\delta^{2} \mathrm{H} \ldots \ldots \ldots \ldots \ldots . . . . . . .120$

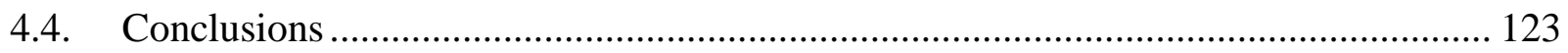

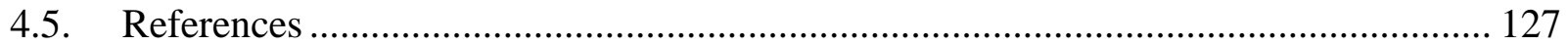

5. Chapter five: Investigating the karst aquifers response to precipitation and pollution events using multi-monitored parameters for groundwater travel time ........................................... 131

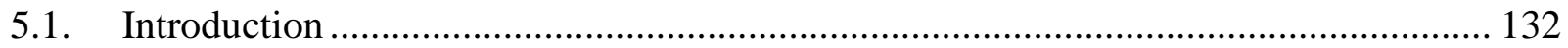

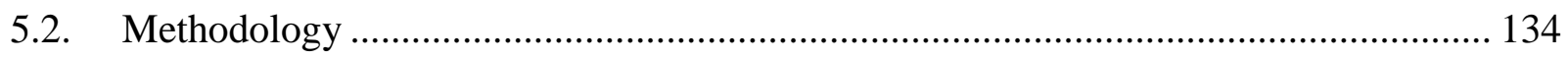

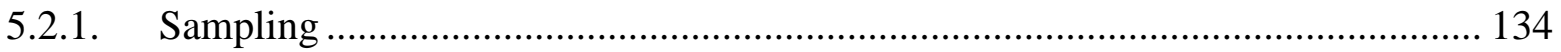

5.2.1.1. Tanour and Rasoun spring water samples ............................................ 134

5.2.1.2. Domestic and olive mills wastewater samples ...................................... 134

5.2.2. Automated telemetry data from Tanour and Rasoun springs ............................ 134

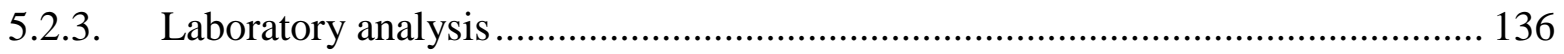

5.2.3.1. Tanour and Rasoun spring water and domestic wastewater samples ............ 136

5.2.3.2. $\quad$ Olive mill wastewater sample.............................................................. 137

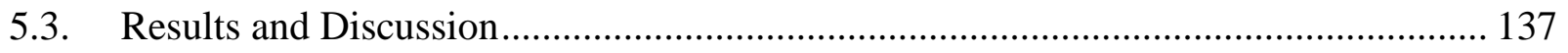

5.3.1. Tanour and Rasoun spring water quality .................................................... 137

5.3.2. $\quad$ Karst aquifer response to pollution events.................................................... 140

5.3.2.1. Pollution events in Tanour spring........................................................... 140

5.3.2.2. Pollution events in Rasoun spring ........................................................ 144 
5.3.3. $\quad$ Using potassium $\left(\mathrm{K}^{+}\right)$concentration to quantify leaked wastewater volume towards

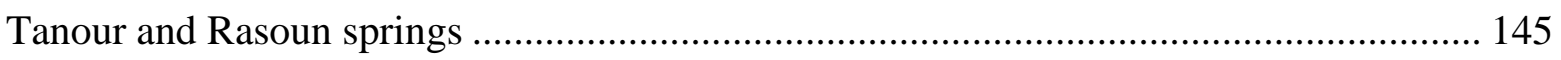

5.3.3.1. Estimation of domestic wastewater load (Rasoun spring)............................. 147

5.3.3.2. Estimation of olive mills wastewater load (Tanour spring) ............................ 150

5.3.4. Determination of water travel time in Tanour spring and investigation of its response to precipitation events................................................................................... 152

5.3.5. Determination of water travel time in Rasoun spring and investigation of its response to precipitation events.................................................................................. 156

5.4. Conclusions ............................................................................................................. 159

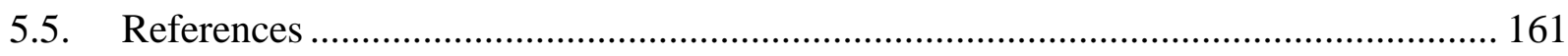

6. Chapter six: Conclusions, future perspectives and recommendations ................................. 165

6.1. Conclusions and future perspectives ........................................................................... 166

6.1.1. Water travel time and vulnerability assessment of the aquifer ............................. 167

6.1.2. Karst aquifer response to pollution events............................................................. 168

6.1.3. Tracer tests (suggested injection locations) ............................................................. 168

6.1.4. Hydrogeological parameters estimation ............................................................. 170

6.2. Recommendations ................................................................................................. 170

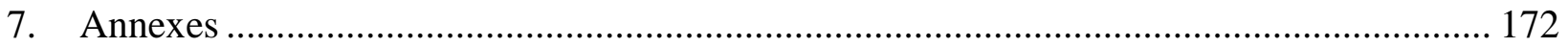

Annex 1: The applied calculations and conversions in the Landsat 8 satellite image to produce a final multi-band Landsat 8 satellite image ………………................................................. 172 Annex 2: The isotopic composition of $\delta^{18} \mathrm{O}$ and $\delta^{2} \mathrm{H}$ in the rainwater samples collected by the IAEA from Ras Munif rain station for the time period between 1984 and 2004 (monthly cumulative rainwater samples)....................................................................................... 176

List of publications within this study...................................................................................... 177

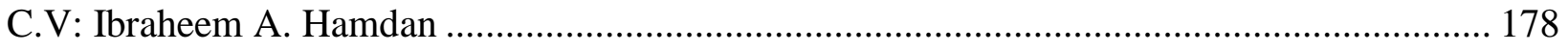




\section{List of figures}

Figure 1-1: Epikarst conceptual diagram (Geyer 2008; modified from Mangin 1975)................. 3

Figure 1-2: Karst system conceptual model (Doerfliger and Zwahlen 1995). ............................ 4

Figure 1-3: (A) Represents the effect of the primary and secondary conduits growth on the hydraulic head and hydraulic gradient, in response of the fast primary conduits growth. (B) represents the fast growth and development of the primary conduits, and increase in size and order downstream (1), and the linking of the secondary conduits together (2-4) (Taylor and Greene 2008; modified after Ford 1999). ....................................................................... 6

Figure 1-4: Duality effect of recharge, storage and flow on the karst aquifer response (Smart and

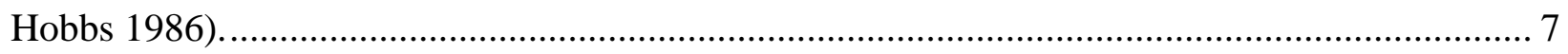

Figure 1-5: Spatial distribution of the long-term average rainfall in Jordan (modified after MWI-

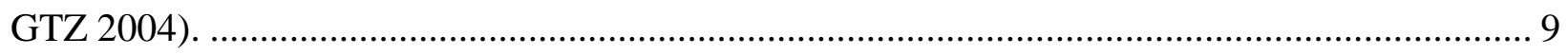

Figure 1-6: Work flow schematic diagram of the study. ........................................................ 12 Figure 2-1: General overview location map for the study area. Background taken from ASTER DEM 30 m resolution (USGS 2014a), "ASTER GDEM is a product of METI and NASA"...... 20 Figure 2-2: 3-D overview map of the catchment area of the Tanour and Rasoun springs.......... 21 Figure 2-3: The calculated long-term average monthly rainfall distribution for the time period 1961/1962 - 2013/2014 (water year)............................................................................... 22 Figure 2-4: Annual pan-A evaporation values measured at AH0003 meteorological station for the

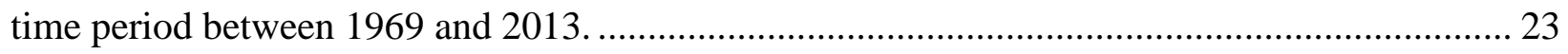
Figure 2-5: Long-term average monthly pan-A evaporation values measured at AH0003 meteorological station for the time period between 1969 and 2013...................................... 24 Figure 2-6: Long-term monthly average minimum and maximum temperature for the station AH0003 for the time period between 1969 and 2013.......................................................... 25

Figure 2-7: Supervised land cover map for the catchment area............................................... 26 Figure 2-8: Soil unit map within the catchment area (level 2) (modified after Ministry of

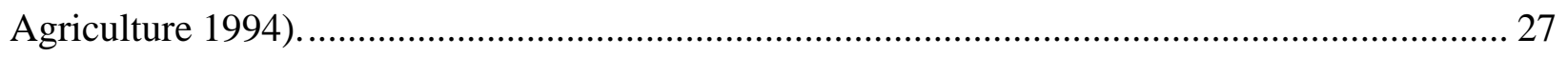

Figure 2-9: Schematic diagram for Tanour spring (photos source: Ibraheem Hamdan)............. 28

Figure 2-10: Schematic diagram for Rasoun spring (photos source: Ibraheem Hamdan)........... 29

Figure 2-11: General overview for Beida spring (photo source: Ibraheem Hamdan). ................ 30

Figure 2-12: Outflow meeting point between Tanour and Beida springs (photo source: Ibraheem

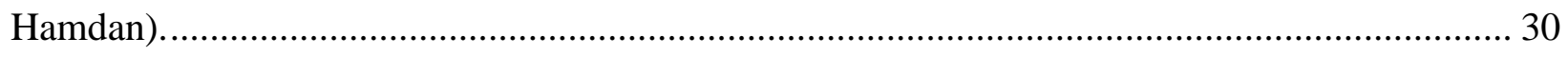

Figure 2-13: Relation between rainfall (Ras Munif station AH0003) and Tanour spring discharge for 1968/1969-2013/2014........................................................................................ 32

Figure 2-14: Relation between rainfall (Ras Munif station AH0003) and Rasoun spring discharge for 1968/1969-2013/2014............................................................................................. 32

Figure 2-15: Geological map of the study area (modified after Abdelhamid 1993 and Abu

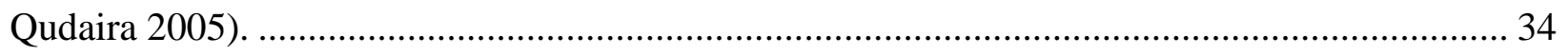


Figure 2-16: Hummar (A4), Shu'ayb (A5/6) and Wadi as Sir geological formation sequence in the study area (photo source: Ibraheem Hamdan). ………............................................................ 35 Figure 2-17: Hummar geological formation (A4) outcrop in the study area (photo source: Ibraheem Hamdan)............................................................................................................. 36

Figure 2-18: Panoramic view of the Tanour spring within the Hummar (A4) geological formation

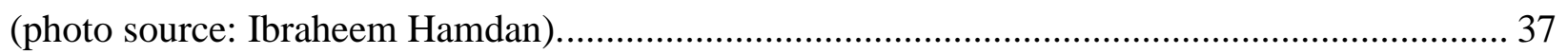
Figure 2-19: Shu'ayb geological formation (A5/6) outcrop in the study area (photo source:

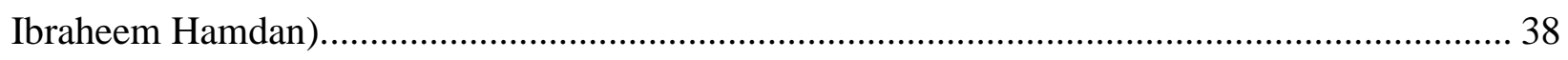
Figure 2-20: Wadi as Sir (A7) geological formation outcrop in the study area (photo source:

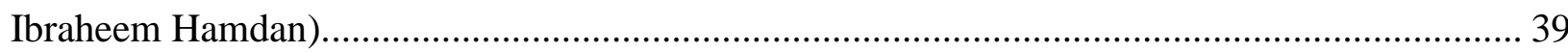
Figure 2-21: Wadi Umm Ghudran (B1) and Amman Silicified limestone (B2) outcrops in the study area (background source:Google Earth image (), March 2016). ...................................... 40 Figure 2-22: Dolines occurring at different scales in the study area: (a) $15 * 15 \mathrm{~m}$, (b) $7 * 5 \mathrm{~m}$, (c) 15*10 m, (d) 3*2 m (photo source: Ibraheem Hamdan).................................................... 43 Figure 2-23: Caves occurring within the study area at different scales (photo source: Ibraheem

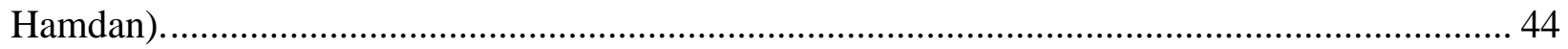
Figure 2-24: Dry valley near the Rasoun spring. (A): outflow from the Rasoun spring during winter, when there is no pumping. (B): the dry valley after the disappearance of water flow into the subsurface drainage system (photo source: Ibraheem Hamdan). 45 Figure 2-25: Fracturing and dissolution of limestone rock formations (photo source: Ibraheem

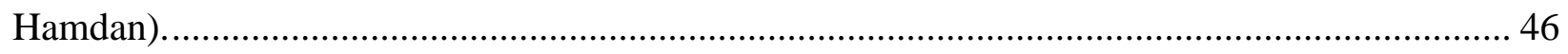
Figure 2-26: Large-scale karst pavement (photo source: Ibraheem Hamdan).............................. 47 Figure 2-27: Base flow recession curve analysis for Tanour spring discharge data corrected using pumping data (based on the daily pumping rate)..................................................................... 50 Figure 2-28: Wadi as Sir (A7) geological formation thickness obtained via the "spline with barrier" ArcGIS interpolation method. …………………....................................................... 53 Figure 2-29: 3-D model view of the geological formations located within the study area: (a) with the geological sheet at the top, and (b) bases of the A1/2, A3, A4, A5/6 and A7 geological

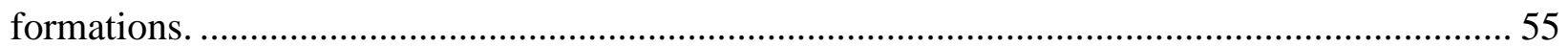
Figure 2-30: Bases of the A1/2, A3, A4, A5/6 and A7 geological formation surfaces (m a.s.l.)

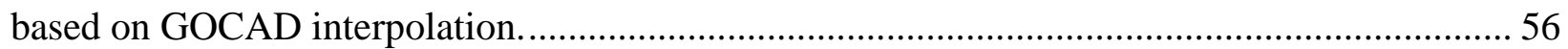
Figure 3-1: Origin-pathway-target model for environmental management (Goldscheider 2003).62 Figure 3-2: Brouyere schematic diagram for the three questions and the related factors, that descriping any pollution event by conservative contaminants.(modified after Brouyere et al. 2001). 63

Figure 3-3: The European approach conceptual model (Goldscheider 2002)............................. 65 Figure 3-4: Relation between the karst network (type and availability) in the carbonate aquifers and the flow concentration (Goldscheider and Popescu 2003)...................................................... 66 Figure 3-5: COP method diagram and the numeric evaluation of Tables I-XVI (Vias et al. 2006). 
Figure 3-6: Standard classification for EPIK parameters (Doerfliger et al. 1999).................... 73

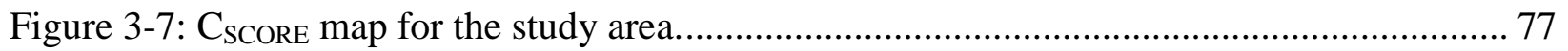

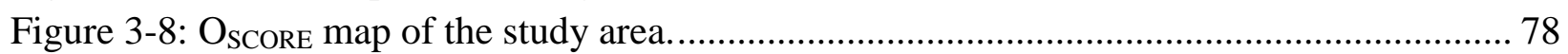

Figure 3-9: Epikarst (E) factor map for the study area.................................................... 80

Figure 3-10: Protective cover (P) factor map for the study area.............................................. 81

Figure 3-11: Karst network development (K) map for the study area....................................... 82

Figure 3-12: COP groundwater vulnerability assessment map for the study area...................... 83

Figure 3-13: EPIK groundwater vulnerability assessment map for the study area..................... 83

Figure 3-14: Vulnerability class percentages; (a) COP vulnerability assessment method, (b) EPIK vulnerability assessment method. .............................................................................. 84

Figure 3-15: Cross-sectional conceptual diagram for water travel time within the epikarst towards a stream as a final recharge point (modified after Brosig et al. 2008).......................... 87 Figure 3-16: Flow diagram for the calculation of groundwater travel time within the catchment.

Figure 3-17: Example of conceptual water flow paths from different model cells within the

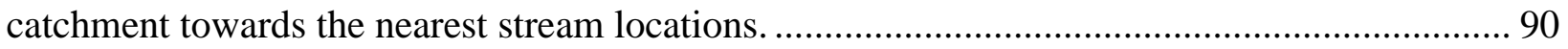
Figure 3-18: Shows: (a): flow length (s) from each pixel (model grid) in the catchment towards the streams, (b): gradient values (dh/dl). ............................................................................ 91 Figure 3-19: Calculated average flow velocity (va) within the epikarst zone based on the three scenarios for the calculated hydraulic conductivity values: (a) with hydraulic conductivity $\mathrm{K}$ of $119 \mathrm{~m} / \mathrm{d}$, (b) hydraulic conductivity K of $71 \mathrm{~m} / \mathrm{d}$, and (c) hydraulic conductivity K of $51 \mathrm{~m} / \mathrm{d}$. . 93 Figure 3-20: Calculated water travel time within the epikarst based on flow path lengths (s) towards the streams, and the three scenarios of the average water flow velocity (va)................ 94 Figure 3-21: Probability density functions (PDF) of the calculated water travel time through the epikarst based on the three assumed scenarios of hydraulic conductivity of the epikarst zone. .. 96 Figure 4-1: Locations of rain and snow samples collection, and Ras Munif meteorological station (AH0003) (modified after Hamdan et al. 2016).

Figure 4-2: Shows (a) samples preparation for analysis, and (b) Liquid Water Isotope Analyzer (LGR, IWA-35-EP) for analyzing $\delta^{18} \mathrm{O}$ and $\delta^{2} \mathrm{H}$ (photo source: Ibraheem Hamdan)................ 112 Figure 4-3: Local Meteoric Water Line (LMWL) for the study area based on rainfall and snow samples collected from catchment in comparison to the Global Meteoric Water Line (GMWL) and the Mediterranean Meteoric Water Line (MMWL) (modified after Hamdan et al. 2016). . 115 Figure 4-4: Variation in $\delta^{18} \mathrm{O}, \delta^{2} \mathrm{H}$ in parallel with the other monitored parameters in Tanour spring water in response to rainfall and snow events (Hamdan et al. 2016). 118 Figure 4-5: Variation in $\delta^{18} \mathrm{O}, \delta^{2} \mathrm{H}$ in parallel with the other monitored parameters in Rasoun spring water in response to rainfall and snow events. 120 Figure 4-6: Difference in response time between Tanour and Rasoun springs (t1, t2) based on the change in $\delta^{18} \mathrm{O}$ values. 125 Figure 4-7: Deviation of Tanour and Rasoun springs isotopic composition from the LMWL during normal base flow conditions (point A), and recharge events (point B). 126 
Figure 5-1: The automated multi-parameter probes that were installed in Tanour and Rasoun springs: (a) SEBA multi-parameter probe and data recorder, (b) HACH-lange multi-parameter probe recorder, and (c) In-situ TROLL multi-parameter probe (photo source: Ibraheem Hamdan). 136

Figure 5-2: (a) Ion Chromatography instrument (IC), and (b) sample preparations for analysis (photo source: Ibraheem Hamdan).. 137

Figure 5-3: Piper diagram representing Tanour and Rasoun spring water types according to Langguth's (1966) classification..... 139

Figure 5-4: Tanour spring water during one of the pollution events from the olive mills wastewater. Water is oily and dark green or black in colour (photo source: Ibraheem Hamdan). 142

Figure 5-5: Variation in indirect TOC, oxygen saturation, turbidity, and EC values in the Tanour spring during the pollution events from the olive mills wastewater...................................... 143

Figure 5-6: Combined chemo-hydrograph for Rasoun spring............................................... 148

Figure 5-7: Calculated leaked domestic wastewater volume towards the Rasoun spring. ......... 149 Figure 5-8: Change in potassium concentration in the Tanour spring during the pollution events from the olive mills wastewater, together with the other monitored parameters....................... 151 Figure 5-9: Calculated leaked olive mills wastewater volume towards the Tanour spring........ 152 Figure 5-10: Tanour spring response to precipitation events based on the changes of water temperature, electrical conductivity, turbidity, spring discharge, and magnesium concentration. 155

Figure 5-11: Rasoun spring response to precipitation events based on changes in turbidity, water temperature, electrical conductivity, and magnesium. 157 Figure 6-1: Compatibility between the applied methods related to the determination of water travel time in karst aquifers. 166 Figure 6-2: Suggested injection locations for tracer tests within the catchment area (photo source: Ibraheem Hamdan) 169 Figure 7-1: Final multi-band Landsat 8 satellite image $15 \mathrm{~m}$ resolution (extended area). 175 


\section{List of tables}

Table 1-1: Comparison between different types of aquifers (granular, fractured and karst aquifers based on different hydrogeological parameters (ASTM 2002). ............................................. 5 Table 1-2: Surface water budget for the year 2013 in comparison with the long-term average rainfall (1990/1991-2012/2013) (MWI 2013a).......................................................................... 9

Table 2-1: Tanour, Rasoun, and Beida springs coordinates. .................................................... 19 Table 2-2: The calculated long-term average yearly rainfall amounts for the time period 1961/1962 - 2013/2014 (water year)................................................................................. 22 Table 2-3: Soil unit description (level 2) within the study area, and soil taxonomy for each subgroup (Ministry of Agriculture 1994)............................................................................. 27

Table 2-4: Long-term minimum, maximum and average discharge for Tanour and Rasoun

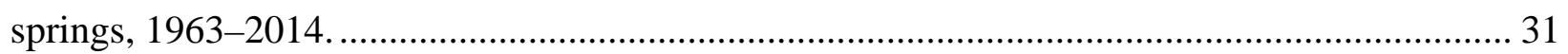

Table 2-5: Yearly production values from the Tanour and Rasoun springs for 1996-2014. ....... 33

Table 2-6: Hydraulic parameter evaluation based on the base flow recession curve analysis for

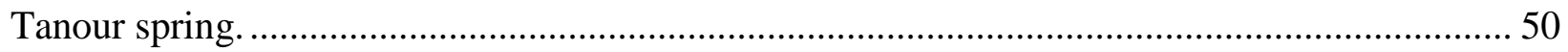

Table 2-7: Geological formation thickness values used in the model. ..................................... 52 Table 3-1: Intrinsic vulnerability assessment methods and the parameters affecting these methods (Doummar 2012). 64

Table 3-2: Data available and required for applying COP and EPIK vulnerability assessment

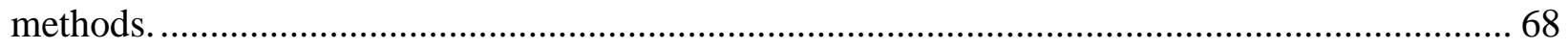

Table 3-3: Standard rates for the EPIK parameters (Doerfliger et al. 1999). ............................ 74

Table 3-4: Standard weighting coefficient for the EPIK parameters (Doerfliger et al. 1999)..... 74

Table 3-5: Vulnerability classes for the EPIK method based on the protection index (F) (Doerfliger and Zwahlen 1998). .................................................................................... 74

Table 3-6: Possible protection index (F) values for the EPIK vulnerability assessment method (Doerfliger and Zwahlen 1998). ....................................................................................... 75

Table 3-7: The long-term average yearly rainfall for the station AH0003 from 1968/1969 and

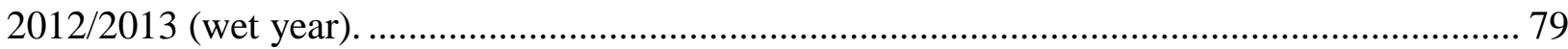

Table 3-8: Intersection percentages between each land cover type within the catchment and vulnerability classes for both, COP and EPIK vulnerability assessment maps......................... 85

Table 3-9: Calculated hydraulic parameters for epikarst zone based on the base flow recession curve analysis for the Tanour spring................................................................................. 92

Table 3-10: Calculated percentage of each water travel time range in each scenario................. 95

Table 3-11: Intersection percentages between urban areas and the water travel time ranges in

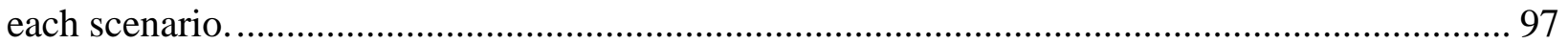

Table 3-12: Intersection percentages between travel time physics-based map (scenario c), and both the COP and EPIK intrinsic vulnerability assessment methods results............................ 98

Table 4-1: Information on rainwater and snow collection sites........................................... 111 
Table 4-2: $\delta^{18} \mathrm{O}$ and $\delta^{2} \mathrm{H}$ composition of rain and snow water samples collected during the winter seasons 2013/2014 and 2014/2015.

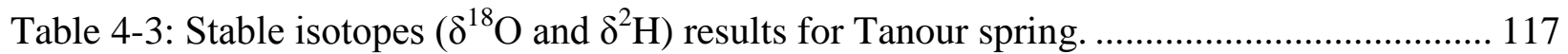

Table 4-4: Stable isotopes $\left(\delta^{18} \mathrm{O}\right.$ and $\left.\delta^{2} \mathrm{H}\right)$ results for Rasoun spring........................................ 121

Table 5-1: Chemical analysis statistics for Tanour and Rasoun springs. .................................... 138

Table 5-2: Classification of water types based on the piper diagram (Langguth 1966)............. 139

Table 5-3: Selected historical analysis for Total Coliforms (MPN/100 ml) and Escherichia Coli (MPN/100 ml) in the Tanour spring water during 2010-2015 (YWC-WAJ 2015a).................. 140

Table 5-4: Chemical analysis of the olive mills wastewater sample. ......................................... 141

Table 5-5: Selected historical analysis for Total Coliforms (MPN/100 ml) and Escherichia Coli (MPN/100 ml) in the Rasoun spring water during 2009-2014 (YWC-WAJ 2015b)................. 145

Table 5-6: Chemical analysis of wastewater samples collected from domestic septic tanks in different locations (September 2015). 149

Table 7-1: Landsat 8 OLI and TIRS Bands ( $\mu$ m) (USGS 2014a), (* OLI Bands, ** TIR Bands).

Table 7-2: Radiance rescaling factors (USGS 2014b (metadata file)). 173 


\section{Summary}

Understanding the karst aquifer response to precipitation and contaminants transport, especially in arid to semi-arid areas, is a very important issue and a challenge due to the unique and heterogeneous characteristics of karst aquifers. Monitoring the water travel time through karst aquifers and the response to precipitation events can provide good information about the characteristics of water and pollutant flow through the aquifer. This can subsequently help provide proper protection for the aquifer against pollution to sustain the water resources for the coming generations.

Within this study, different methods and approaches were developed and applied in order to characterise the karst aquifer system of the Tanour and Rasoun springs and the flow dynamics within the aquifer and to develop a process-oriented method for vulnerability assessment based on the monitoring of different multi-spatially variable parameters of travel time. The karst aquifer of the Tanour and Rasoun springs (about $75 \mathrm{~km}^{2}$ northwest of the capital city of Amman) catchment area $\left(\sim 36 \mathrm{~km}^{2}\right)$ was chosen as a case study due to the pollution events that occur at both of the springs, the high importance of these karst springs as the primary local drinking water supply for the surrounding villages and to fill a gap in the literature regarding the characteristics of the karst aquifer in this area.

To better understand the vulnerability of the karst aquifer of the Tanour and Rasoun springs to pollution events and the capability of the aquifer for the natural attenuation of pollutants based on the natural characteristics of the aquifer itself, COP and EPIK intrinsic vulnerability assessment methods were applied. Based on the applied COP method, spatial distribution of groundwater vulnerability is as follows: (1) high (37\%), (2) moderate (34.8\%), (3) low (20.1\%), and (4) very low (8.1\%). While in the EPIK vulnerability assessment method, only two out of four vulnerability classes characterise the catchment area: very highly vulnerable areas (38.4\%) and moderately vulnerable areas (61.6\%).

The understanding of the groundwater pathways and movement within the epikarst is fundamental to evaluate pollution risks from point and non-point sources in karst aquifer systems. A travel time physics based method was developed and applied by integrating flow path lengths with the sub-surface groundwater transport velocity through the epikarst zone, towards 
the streams as a final recharge point. The base flow recession curve method was used in order to estimate the transmissivity values of the epikarst zone as $3.58 * 10^{2} \mathrm{~m}^{2} / \mathrm{d}$. Final water travel times were applied within three different scenarios of the hydraulic conductivity values of the epikarst zone, which was calculated based on three different assumed thicknesses of the epikarst zone. The applied method showed that around $97 \%$ of the catchment area exhibits a water travel time of up to 5 days.

The analysed stable isotopes of oxygen and hydrogen in both of the Tanour and Rasoun springs water, in combination with other different automated monitored parameters, including turbidity, water temperature and electrical conductivity, in addition to the Tanour spring discharge, showed that the springs response to precipitation events is very rapid. Both springs responded to the rainfall events with an maximum water travel time of two to four days, except during the two intensive snowfall events that occurred in the winter season 2014/2015, where the maximum water travel time was nine to eleven day for the first snowfall event and three to five days for the second snowfall event. The difference in water travel times between the two snow events is related to other different factors that affected the snow melting process. The LMWL for the catchment area was defined as $\delta^{2} \mathrm{H}=7.66 * \delta^{18} \mathrm{O}+24.43 \%$ o $\left(\mathrm{R}^{2}=0.98\right)$.

Pollution events in karst aquifers is a big problem due to the limited natural attenuation of pollutants resulting from fast water travel times and the thin, or absent, protective cover. At Tanour spring, both of the TOC and oxygen saturation showed a high sensitivity to pollution events from the olive mills wastewater. Clear, strong and wide-ranging potassium concentration peaks were recorded in Tanour and Rasoun springs during the pollution and recharge events. The measured potassium concentrations were used in order to develop a method for the quantification of the leaked wastewater towards Tanour spring (from the olive mills wastewater) and Rasoun spring (from domestic wastewater), based on the springs discharge volumes and the measured potassium concentration in the springs water and in the undiluted wastewater. 


\section{Dedication}

To the soul of my mother who dedicated her life for us.

To my father; my idol and supporter

To my brothers, sisters'

To my lovely family: "my wife and my children" 


\section{Acknowledgment}

This thesis would not exist without the support and assistance of many individuals, institutes and ministries. First, I would like to thank Prof. Dr. Martin Sauter, Prof. Dr-Ing. Thomas Ptak and Dr. Bettina Wiegand for their supervision of this work and their continuous support and valuable suggestions, which enabled me to complete this $\mathrm{PhD}$ thesis within the frame of the scholarship.

I would like to thank the Federal Ministry of Education and Research (BMBF) and the German Academic Exchange Service (DAAD), special program "Sustainable Water Management (NaWaM)", study scholarships and research grants 14 (56322373), for providing me this opportunity to pursue my doctoral studies by financing the entire period of research.

I would like to express my gratitude to Eng. Ali Subah from the Ministry of Water and Irrigation (MWI) for his great support related to providing the necessary data and the use of the automated online data from the Tanour spring telemetry station.

I would like to thank Dr. Mathias Toll, from the Federal German Institute for Geosciences and Natural Resources (BGR), within the framework of the Jordanian-German technical cooperation project "Water Aspects in Land-use Planning", Jordan, for providing the automated online data from the Tanour spring telemetry station for use in this study. I would like to thank the staff of the BGR project in Jordan, especially Mr. Mohammad Al-Hiary, Omed Al-Kurdi and Mr. Florian Brückner for their support and help in collecting the water samples and other related data.

Many thanks to Dr. Armin Margane from the BGR for his support, valuable advice and for his help in the monitoring of the Rasoun spring water.

I'm very grateful to Eng. Kifah Mrayan from the Yarmouk Water Company (YWC) and Water Authority of Jordan (WAJ) for logistic support and providing me with the necessary data and the personnel at Tanour spring for their help in collecting water samples.

I would like to thank Mr. Hussein Hamdan, Mr. Mohammad Al-Atrash, Mr. Thair Al-Momany and Mr. Refat Bani Khalaf for their help providing various necessary data. Many thanks to Dr. Tobias Licha, Dr. Bianca Wagner, Dr. Tobias Geyer, Dr. Sebastian Schmidt, Mr. Ethan Inlander, and Mr. Calvin Wolters for their advice. 
Many thanks to Mr. Muhannad Masad from Al-Albayt University, Jordan for his help in the analysis of the olive mill wastewater sample and to Mrs. Mechthild Rittmeier in the department of applied geology in Georg-August-University Göttingen, for her help in the analysis of the spring water samples.

My deepest thanks to all doctors, colleagues and friends at the department of applied geology in Georg-August-University Göttingen, for the nice times we shared together during the whole study period, especially Dr. Chicgoua Noubactep and Dr. Shyamal Karmakar.

My big thank to my father, brothers and sisters for their help, support and encouragement. Last, but not the least, my deepest gratitude to my lovely wife, Sally for her support and patience during my studies and for my lovely children, Shadi and Tala: they bring a big smile to my face. 


\section{Chapter one: Introduction}




\subsection{Introduction to karst systems}

\subsubsection{Background and definition of karst systems}

According to Ford and Williams (2007) and Hartmann et al. (2014), the term karst is used to express a special type of landscape forms which is developed typically from carbonate rocks, such as calcite $\left(\mathrm{CaCO}_{3}\right)$ and dolomite $\left(\mathrm{CaMg}\left(\mathrm{CO}_{3}\right)_{2}\right)$. According to Bakalowicz (2005), Karstification can also take place in evaporite formations, gypsum, anhydrite.

Karst aquifers represent a very important source of water throughout the world. Around one quarter of the population around the world depending mainly on groundwater obtained from karst aquifers which is covered in total $7-12 \%$ of the earth continental area (Ford and Williams 2007, Hartmann et al. 2014). However, karst aquifers are highly vulnerable to contamination, exhibiting a strong hydraulic and hydrochemical response during and after rainfall events because of the high water flow velocity within the karst features and karst networks. According to Hartmann et al. (2014), the dissolution of carbonate rocks can be described by the following equation:

$$
\mathrm{CaCO}_{3}+\mathrm{H}_{2} \mathrm{O}+\mathrm{CO}_{2} \leftrightarrow \mathrm{Ca}^{2+}+2 \mathrm{HCO}_{3}^{2-}
$$

Aquilina et al. (2006) divided karst aquifers into three main parts as follow:

1. The "non-karst recharge area". This part of the aquifer overlying the karstic layers and consists of low permeable layers (bedrock or soil).

2. The epikarst zone. This zone comprises the highly weathered upper part of the karst aquifer, with a typical thickness range from few of centimetres to reach around 30 metre or more (Jones 2013, Williams 2008, Goldscheider and Andreo 2007, Treek 2007). Figure 1-1 represents a conceptual model of the epikarst.

3. The saturated karst zone, which is normally connected to a spring as an outlet.

Karst systems contain a number of distinguishing features, including thin soils, dolines, swallow holes, dry valleys, in addition to the highly concentrated flow within the epikarst zone (Zwahlen et al. 2003). Figure 1-2 represents a conceptual model for karst systems. The absence of the karst features on the surface doesn't mean that the system is not a karst system, where karst systems can develop underground even if the karst features are not apparent on the surface (Ford and Williams 2007). 
According to the conceptual model suggested by Geyer et al. (2007), the flow in karst aquifer conduits is often turbulent, and the flow velocity within the karst conduits increasing along the centreline of the conduit, while it decreases toward the wall of the conduit itself.

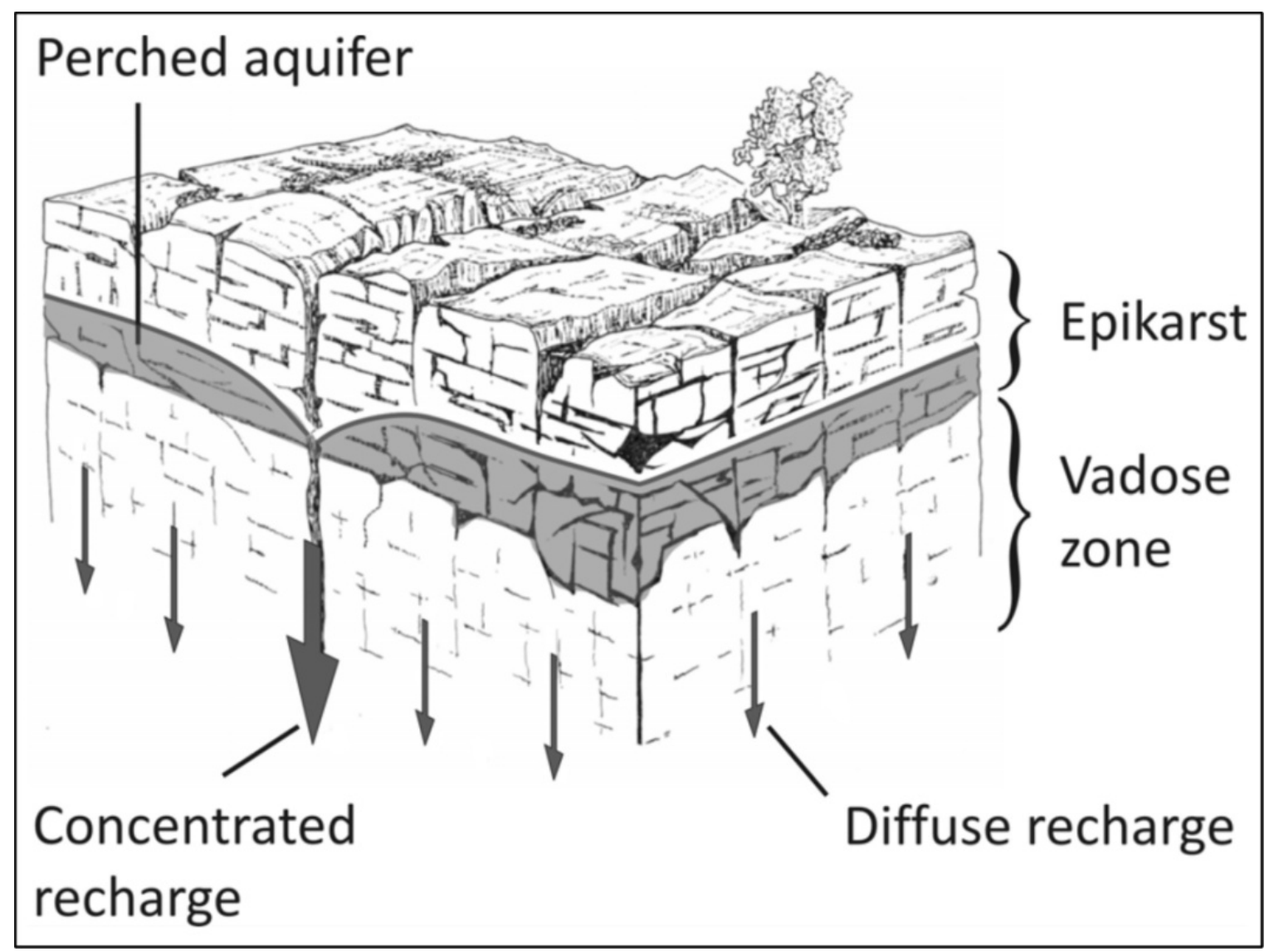

Figure 1-1: Epikarst conceptual diagram (Geyer 2008; modified from Mangin 1975). 


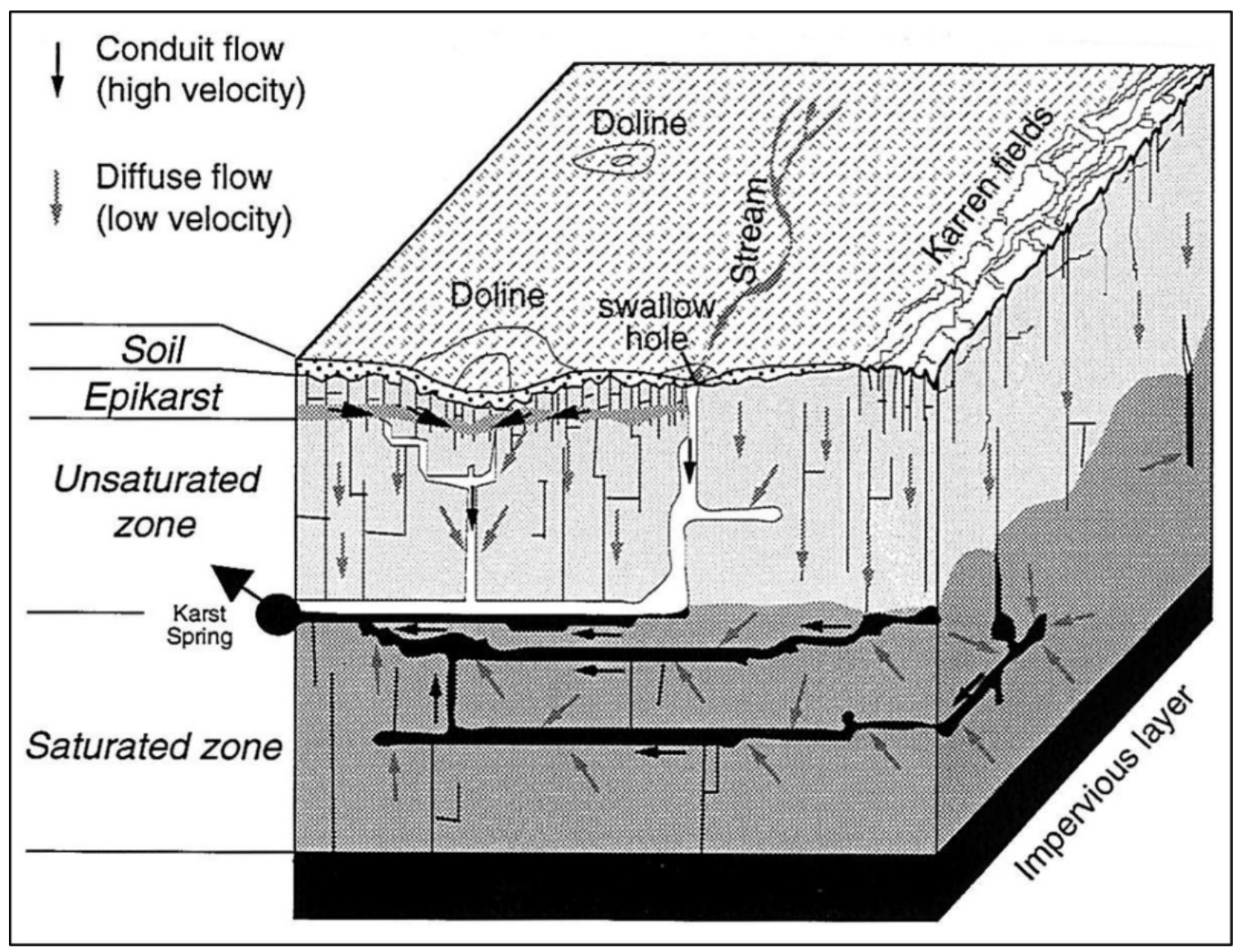

Figure 1-2: Karst system conceptual model (Doerfliger and Zwahlen 1995).

\subsubsection{Characterization of karst aquifers}

Karst aquifers are highly susceptible to short-lived contaminants due to their unique structure (strongly heterogeneous), and the fast water travel times and low storage capacity in the conduit system compared with other aquifer types. This unique structure of the karst aquifers leads to the infectiveness of many processes of contaminant attenuation such as filtration, adsorption and chemical and microbiological decay (Doerfliger et al. 1999, Zwahlen et al. 2003, Goldscheider et al. 2007, Butscher and Huggenberger 2009). Table 1-1 represents a comparison between different hydrogeological properties for granular, fractured and karst aquifers. 
Table 1-1: Comparison between different types of aquifers (granular, fractured and karst aquifers based on different hydrogeological parameters (ASTM 2002).

\begin{tabular}{|c|c|c|c|}
\hline \multirow{2}{*}{$\begin{array}{c}\text { Aquifer } \\
\text { characteristics }\end{array}$} & \multicolumn{3}{|c|}{ Aquifer type } \\
\hline & Granular & Fractured rock & Karst \\
\hline $\begin{array}{l}\text { Effective } \\
\text { Porosity }\end{array}$ & $\begin{array}{l}\text { Mostly primary, } \\
\text { through } \\
\text { intergranular } \\
\text { pores }\end{array}$ & $\begin{array}{l}\text { Mostly secondary, } \\
\text { through joints, } \\
\text { fractures and bedding } \\
\text { plane partings }\end{array}$ & $\begin{array}{c}\text { Mostly tertiary (secondary } \\
\text { porosity modified by } \\
\text { dissolution; through pores, } \\
\text { bedding planes, fractures, } \\
\text { conduits and caves }\end{array}$ \\
\hline Isotropy & More isotropic & Probably anisotropic & Highly anisotropic \\
\hline Homogeneity & $\begin{array}{c}\text { More } \\
\text { homogeneous }\end{array}$ & Less homogeneous & Heterogeneous \\
\hline Flow & Slow, laminar & $\begin{array}{l}\text { Possibly rapid and } \\
\text { possibly turbulent }\end{array}$ & $\begin{array}{c}\text { Likely rapid and likely } \\
\text { turbulent }\end{array}$ \\
\hline $\begin{array}{c}\text { Flow } \\
\text { predictions }\end{array}$ & $\begin{array}{c}\text { Darcy's law } \\
\text { usually applies }\end{array}$ & $\begin{array}{l}\text { Darcy's law may not } \\
\text { apply }\end{array}$ & Darcy's law rarely applies \\
\hline $\begin{array}{l}\text { Storage } \\
\end{array}$ & $\begin{array}{l}\text { Within saturated } \\
\text { zone }\end{array}$ & Within saturated zone & $\begin{array}{c}\begin{array}{c}\text { Within both saturated zone } \\
\text { and epikarst }\end{array} \\
\end{array}$ \\
\hline Recharge & Dispersed & $\begin{array}{l}\text { Primarily dispersed, } \\
\text { with some point } \\
\text { recharge }\end{array}$ & $\begin{array}{c}\text { Ranges from almost } \\
\text { completely dispersed to } \\
\text { almost completely point- } \\
\text { recharge }\end{array}$ \\
\hline
\end{tabular}

The conduit network represents the most distinctive feature of the karst aquifer. During the water flow in the carbonate rocks, different processes may occur: fractures enlarging and grow into conduits, increasing the hydraulic capacity of the aquifer, conduits join together as "tributaries", and then start increase in both of the size and order towards downstream (Palmer 1991, Goldscheider et al. 2007, Taylor and Greene 2008). Figure 1-3 illustrates the process of conduit growth and its effect on hydraulic flow. 

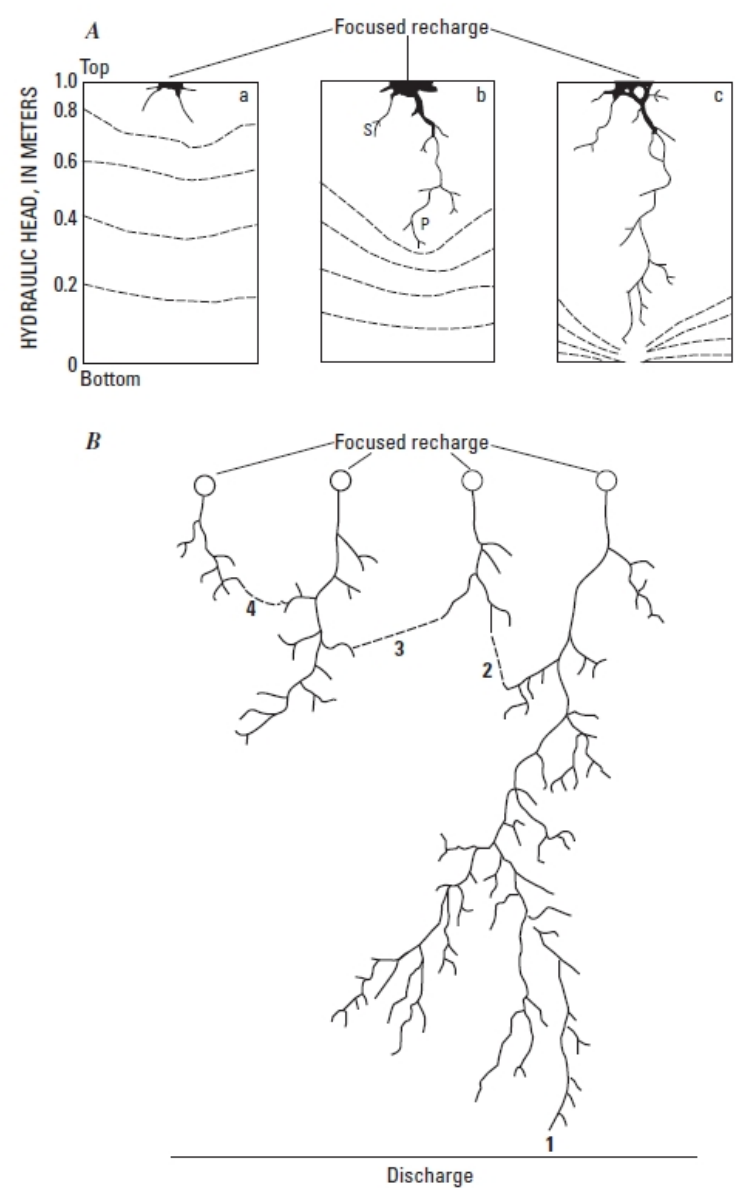

Figure 1-3: (A) Represents the effect of the primary and secondary conduits growth on the hydraulic head and hydraulic gradient, in response of the fast primary conduits growth. (B) represents the fast growth and development of the primary conduits, and increase in size and order downstream (1), and the linking of the secondary conduits together (2-4) (Taylor and Greene 2008; modified after Ford 1999).

Karstic aquifers are characterized by dual or sometimes by triple porosity. Dual porosity is a result of fractures and conduits, while triple porosity occurs due to the presence of the intergranular pores in the karst aquifer as an aquifer matrix. Due to that, the groundwater storage in karst aquifers occur in pores and fractures, comparing with the conduits which is behaving as a drains (Goldscheider 2003, Goldscheider et al. 2007). According to Kiraly (2003), karst aquifers has duality of: infiltration (diffuse or concentrated), groundwater flow (diffuse flow in the fractured or concentrated flow within the conduits), and discharge conditions 
(diffuse discharge due the water flow within low permeable volume, or concentrated discharge due to the availability of channel or conduits network connected directly with a spring). Figure 1-4 representing a schematic diagram proposed by Smart and Hobbs (1986) for the duality of karst systems by proposing a relationship between input and output, based on the duality of recharge, storage and groundwater flow.

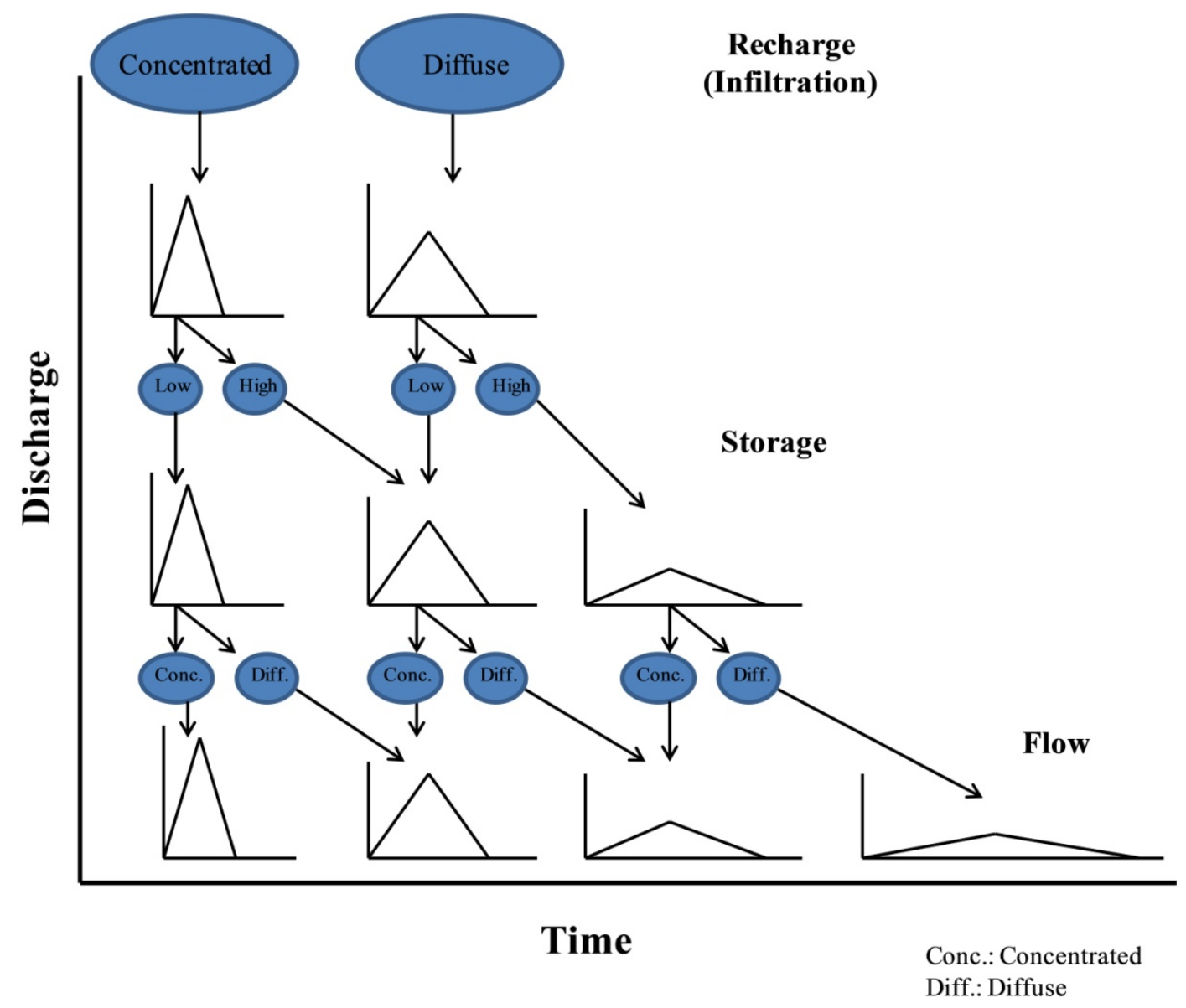

Figure 1-4: Duality effect of recharge, storage and flow on the karst aquifer response (Smart and Hobbs 1986).

\subsection{General overview - water situation in Jordan}

Water resources in Jordan are extremely scarce. Jordan is considered as one of the poorest countries in the world with respect to water resources (UNDP 2014). The available water resources are only approximately $150 \mathrm{~m}^{3} /$ capita and year compared to the international standards 
of $500 \mathrm{~m}^{3} /$ capita and year (MWI 2011). For example, the water supply ranged between 129-154 liter/capita and day during the time period of 2000 to 2013 (MWI 2013a), compared to the normal consumption rate of 170 liters/capita and day according to the WHO standards (Denny et al. 2008).

Groundwater is the main available water resource in Jordan. From the twelve major groundwater basins in Jordan, six are over extracted, four are at capacity (safe yield), and two are underexploited (Denny et al. 2008). The groundwater balance for the year 2012/2013 (based on an assumed safe yield) was (-178) million $\mathrm{m}^{3}$ (MWI 2013b).

The climate of Jordan ranges from Mediterranean in the western part to semi-arid and arid in the eastern part of the country. Summers are hot and dry, while winters are cold and humid. The average maximum temperatures in the capital Amman is $14.1{ }^{\circ} \mathrm{C}$ during the winter and $32{ }^{\circ} \mathrm{C}$ during summer. The average minimum temperatures are $4.5^{\circ} \mathrm{C}$ during the winter and $18.4{ }^{\circ} \mathrm{C}$ during the summer (Nortcliff et al. 2011, JMD 2014).

Water resources in Jordan are influenced by different parameters. The prevailing climatic conditions (low rainfall and high evaporation rates) in conjunction with over-exploitation of groundwater aquifers are regarded to be the main natural causes for declining groundwater tables throughout the past decades. High growth rates of the population (2.4\%) since 2004 (DOS 2013) and the sudden influx of refugees especially within the last years has led to an increasing demand of water.

Around 90\% of the country's area receives less than $200 \mathrm{~mm}$ rainfall per year (Al Kharadsheh et al. 2012). Based on the long-term average annual rainfall in Jordan for the time period between 1963 and 2002 (MWI-GTZ 2004; 2006); the average annual precipitation ranges in Jordan from less than $100 \mathrm{~mm} / \mathrm{yr}$ in the eastern and southeastern part (Badia and southern desert), to around $650 \mathrm{~mm} / \mathrm{yr}$ in the northwestern highlands (near to the Ajloun area) (Figure 1-5). 


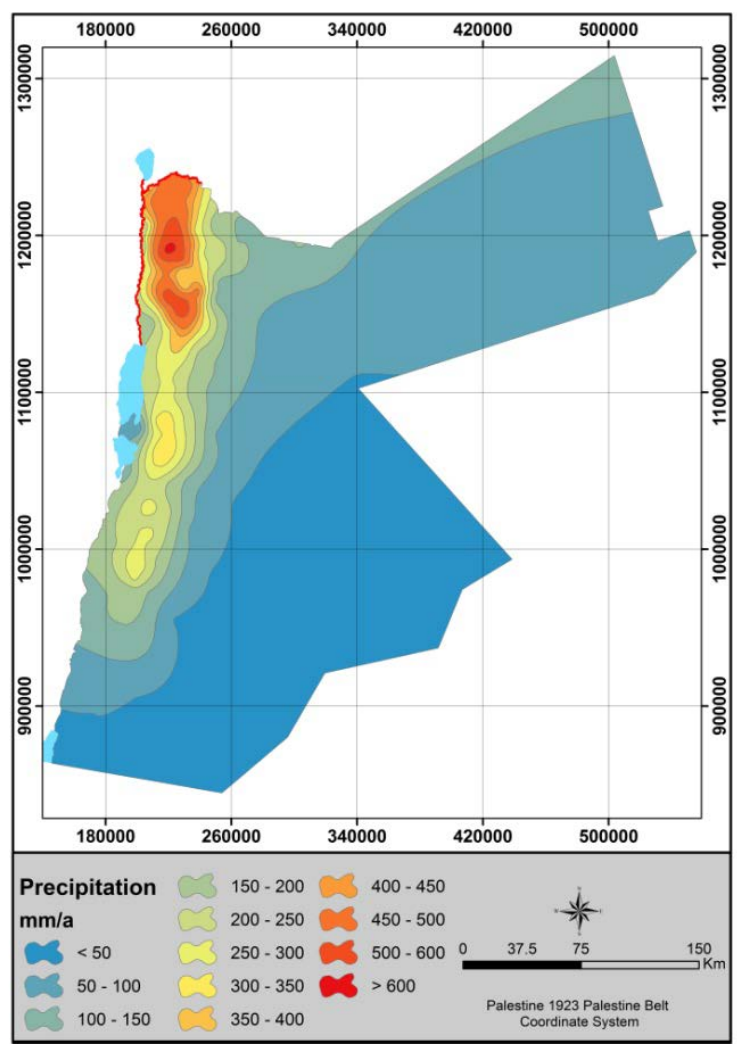

Figure 1-5: Spatial distribution of the long-term average rainfall in Jordan (modified after MWI-GTZ 2004).

Based on long-term average rainfall data for the period 1990/1991 to 2012/2013 (Table 1-2), evaporation losses were calculated to $92.5 \%$ in addition to $2.4 \%$ accounting for runoff. $5.1 \%$ of the rainfall is recharged.

Table 1-2: Surface water budget for the year 2013 in comparison with the long-term average rainfall (1990/1991-2012/2013) (MWI 2013a).

\begin{tabular}{|l|c|c|c|}
\hline & $\begin{array}{c}\text { Rainfall 2013 } \\
\text { (MCM*) }\end{array}$ & $\begin{array}{c}\text { Percentage from } \\
\text { rainfall (\%) }\end{array}$ & $\begin{array}{c}\text { Long-term rainfall (1990/1991- } \\
\text { 2012/2013) (MCM*) }\end{array}$ \\
\hline Rainfall & 8120 & & 8194 \\
\hline Evaporation & 7689 & 94.7 & 7582 \\
\hline Runoff & 187 & 2.3 & 194 \\
\hline Recharge & 244 & 3.0 & 418 \\
\hline * MCM: Million Cubic Meter & \multicolumn{3}{|l}{} \\
\hline
\end{tabular}




\subsection{Research motivation, challenges, and objectives}

The geology of Jordan comprises large areas composed of limestone, and groundwater, which is the primary source of drinking water, is mainly stored in karst aquifers. In spite of the great importance of the karst aquifer for drinking purposes, karst aquifer systems are generally susceptible to pollution, and groundwater quality is a complex issue because of the heterogeneous hydrogeological characteristics and pathways in the karst system and the fast travel time of water and pollutants through the karst features. Understanding of groundwater travel time through the karst aquifers and its response to precipitation and pollution events is a fundamental for evaluating pollution risks from point and non-point pollution sources especially in the context of the abstraction of groundwater for drinking water purposes.

Tanour and Rasoun karst springs (about $75 \mathrm{~km}$ northwest of the capital city of Amman) are considered as the main drinking water supply source for the surrounding villages, where most of the drilled wells have failed due to the complexity of the geological and geomorphological setting of the karst area. During the past years and continuing until the present, the water supply from these two springs has had to be disconnected due to high contamination of the springs water by either (1) microbiological contaminants from wastewater leakage from septic tanks or (2) wastewater from the local olive oil presses, which is called "Zeebar" locally. Normally, Tanour spring is contaminated by both olive mills wastewater and microbiological contaminants, while Rasoun only experiences pollution events caused by microbiological contaminants, as all of the villages surrounding the springs are still not connected to the sewage system.

Due to different factors such as the high importance of Tanour and Rasoun karst springs as main local water resources for drinking purposes, the high sensitivity of the karst aquifers to pollution events that occur in both of the springs, especially during the winter season, the shortage or absence of the previous studies on the catchment area and the need for a better understanding of the response of the karst aquifer of Tanour and Rasoun springs to precipitation events, the vision of this study was developed by integrating different approaches and methods in order to investigate and characterize the groundwater flow dynamics of the water travel time within the karst aquifer of Tanour and Rasoun springs and carrying out an assessment of its vulnerability to pollution events. 
The scarcity of data and studies poses a challenge within the study area. Therefore, all necessary data for this study were collected and prepared directly by analysing and monitoring the spring water, carrying out a detailed geological survey of the karst features and karst network, and applying different techniques, models, and calculations using the collected and analysed data. In addition to that, the Ministry of Water and Irrigation (MWI), Jordan, in cooperation with the Federal Institute for Geosciences and Natural Resources (BGR), Germany, within the frame of the Jordanian-German technical cooperation, have started to monitor Tanour and Rasoun springs by using online automated multi-probes and data loggers. An agreement between the Georg August University Göttingen and MWI-BGR was approved in order to receive the raw measured data, process it, analyse it, and use it in some parts of this study.

In general, this study aims to achieve two main objectives:

$>$ Characterization of the karst aquifer system and flow dynamics.

Development of a process-oriented method for vulnerability assessment based on spatially variable parameters of travel time.

Different procedures and methods were applied in order to achieve these aims starting from the understanding of the geological and hydrogeological characteristics of the karst aquifer and its vulnerability against pollutants, to using different methods, procedures and monitored parameters in order to determine the water travel time within the aquifer and investigate its response to precipitation event and, finally, with the study of the aquifer response to pollution events and estimation of the amount of the leaked wastewater moving in the aquifer towards the springs. Figure 1-6 represents the work flow diagram of the applied methods and procedures in this study. 


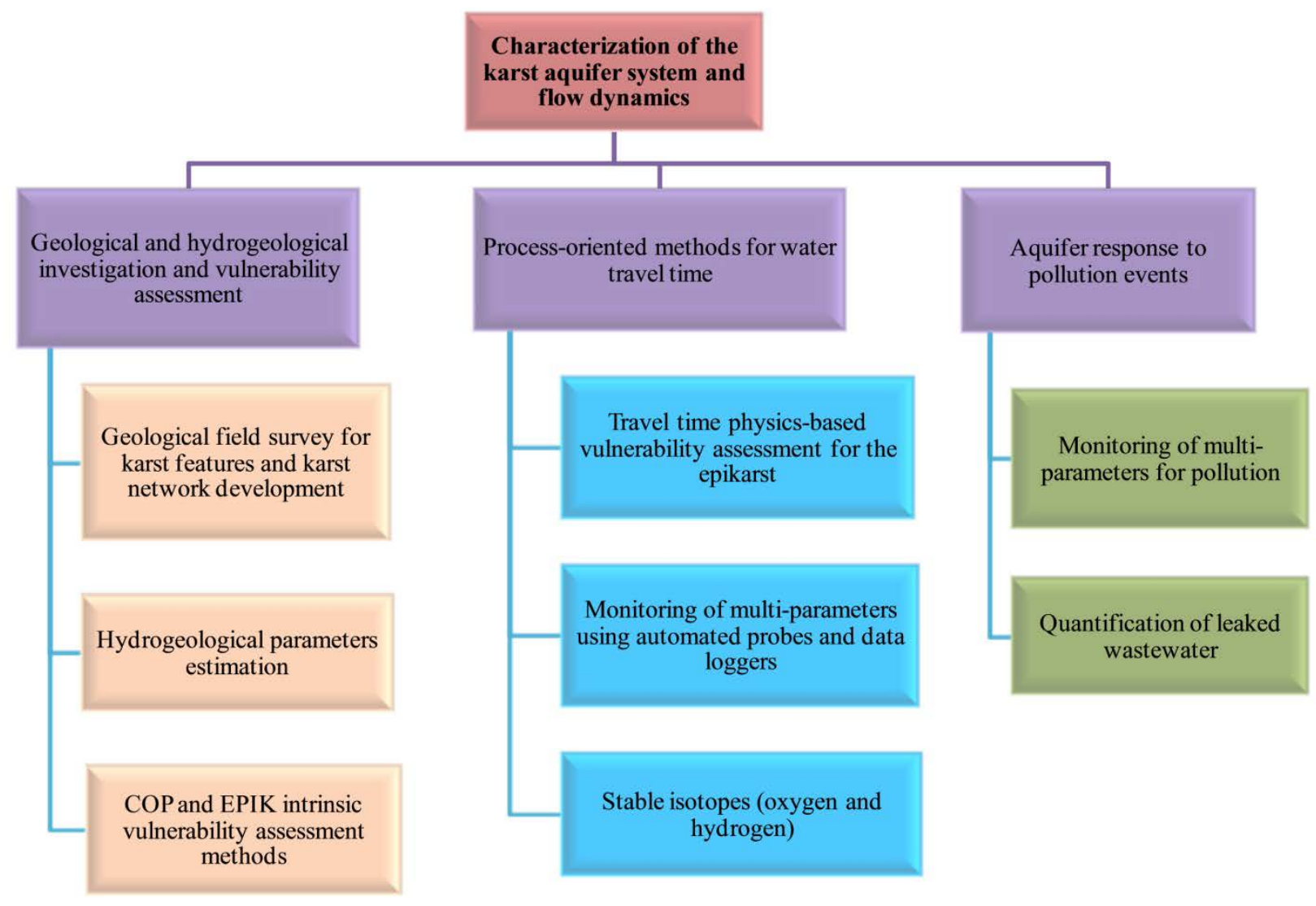

Figure 1-6: Work flow schematic diagram of the study.

\subsection{Thesis structure}

This thesis represents different procedures and methods were applied and developed in order to the development of a process-oriented methods for vulnerability assessment in the karst aquifers based on a spatially variable parameters for water travel time. For that purpose, the thesis was divided into six main chapters. The current chapter (Chapter One) presents a general introduction to karst aquifers and their characteristics, general overview of the water problem and scarcity in Jordan, the research motivation, challenges, and objectives, and the structure of the thesis. By choosing the Tanour and Rasoun karst springs as a case study, Chapter Two describes the geographical location and topography of the study area, climate, soil, land cover, and Tanour and Rasoun springs discharge in addition to providing a descriptive explanation of Tanour and Rasoun springs infrastructure. In addition, this chapter provides a detailed geological 
and hydrogeological description of the study area, a detailed description of the available karst features within the area, and an estimation of the hydrogeological parameters of the karst aquifer of Tanour and Rasoun springs.

Chapter Three is divided into three parts. The first part describes the groundwater vulnerability assessment mapping concepts for karst aquifers. Part Two provides a detailed description of two intrinsic groundwater vulnerability assessment methods for the karst aquifers (COP and EPIK) and applies these two methods within the karst aquifer of Tanour and Rasoun springs. Part Three focuses on developing and applying a groundwater travel time physics-based vulnerability assessment for the non-point pollution sources in the karst aquifers based on the water flow in the epikarst towards the streams as the final recharge points.

Chapter Four and Five were divided into two main parts. The first part focuses on the using of the stable isotopes of oxygen and hydrogen in the water discharge of both Tanour and Rasoun springs, in addition to the data from the automated monitoring telemetry stations that have been installed in Tanour and Rasoun springs in order to determine the water travel time and the karst aquifer response to precipitation events. In contrast, the second part focuses on the hydrochemistry of Tanour and Rasoun spring waters and the pollution events that occurred in both springs, and quantifies the volume of wastewater leaked towards Tanour and Rasoun springs during the recharge and pollution events.

Chapter Six provides a general combined conclusion regarding the results obtained from all of the applied methods and procedures within this study and also presents the future perspectives and recommendations.

\subsection{References}

Al Kharadsheh E., Akroush S., Mazahreh S. (2012) Land degradation in Jordan- review of knowledge resources. International Center for Agricultural Research in the Dry Areas (ICARDA). OASIS country report 1, Aleppo, Syria. 
Aquilina L., Ladouche B., Dörfliger, N. (2006) Water storage and transfer in the epikarst of karstic systems during high flow periods. Journal of Hydrology. 327:472-485; doi 10.1016/j.jhydrol.2005.11.054.

ASTM Subcommittee D-18-21 (2002) Standard guide for design of ground-water monitoring systems in karst and fractured-rock aquifers. West Conshohocken, Pa., American Society of Testing and Materials. Annual book of ASTM standards, v. 04.08, ASTM D5717-95. p. 1421-1438 (cited in Taylor and Greene 2008).

Bakalowicz M. (2005) Karst groundwater: a challenge for new resources. Hydrogeology Journal. 13:148-160.

Butscher C., Huggenberger P. (2009) Modeling the temporal variability of karst groundwater vulnerability, with implication for climate change. Environmental Science and Technology. 43(6):1665-1669.

Denny E., Donnelly K., McKay R., Ponte G., Uetake T. (2008) Sustainable water strategies for Jordan. International economic development program, University of Michigan, Ann Arbor.

Doerfliger N., Jeannin P.-Y., Zwahlen F. (1999) Water vulnerability assessment in karst environments: a new method of defining protection areas using a multi-attribute approach and GIS tools (EPIK method). Environmental Geology Journal. 39(2):165176.

Doerfliger N., Zwahlen F. (1995) EPIK: a new method for outlining of protection areas in karst environment. In: Günay G., Johnson I. (eds): Proceedings 5th international symposium and field seminar on karst waters and environmental impacts. Antalya, September 1995. Balkema, Rotterdam. p. 117-123 (cited in Doerfliger et al. 1999).

DOS (Department of statistics) (2013) Jordan Statistical Yearbook 2013. Issue 64. Amman, Jordan.

Ford D.C. (1999) Perspectives in karst hydrogeology and cavern genesis. In: Palmer A.N., Palmer, M.V., Sasowsky I.D. (eds): Karst modeling: Leesburg, Va. Karst Waters Institute Special Publication 5, p 17-29 (cited in Taylor and Greene 2008). 
Ford D., Williams P. (2007) Karst hydrogeology and geomorphology. Second edn. John Wiley and Sons, Ltd. England.

Geyer T., Brike S., Licha T., Liedel R., Sauter M. (2007) Multitracer test approach to characterize reactive transport in karst aquifers. Ground Water Journal. 45(1):36-45.

Geyer T. (2008) Process-based characterisation of flow and transport in karst aquifers at catchment scale. PhD dissertation, University of Göttingen. Göttingen, Germany.

Goldscheider N. (2003) Groundwater vulnerability (the concept of groundwater vulnerability). In: Zwahlen F. (eds): COST action 620-vulnerability and risk mapping for the protection of carbonate (karst) aquifers. Final Report, p. 5-9.

Goldscheider N., Drew D., Worthington S. (2007) Methods in karst hydrogeology (introduction). In: Goldscheider N., Drew D. (eds): Methods in karst hydrogeology. International association of hydrogeologists, IAH book series No. 26. Taylor and Francis group. London, UK. p. 1-8.

Goldscheider N., Andreo B. (2007) The geological and geomorphological framework. In: Goldscheider N., Drew D. (eds): Methods in karst hydrogeology. International association of hydrogeologists, IAH book series No. 26. Taylor and Francis group. London, UK. P. 9-27.

Hartmann A., Goldscheider N., Wagener T., Lange J., Weiler M. (2014) Karst water resources in a changing world: review of hydrological modeling approaches. Review Article. Geophys. 52:1-25; doi 10.1002/2013RG000443.

JMD (Jordan Meteorological Department) (2014) Jordan Climate. Open source internet file. Accessed: May 2015. Available from: http://www.jometeo.gov.jo/WeatherReports.aspx.

Jones W. (2013) Physical structure of the epikarst. Acta Carsologica 42/2-3: 311-314.

Kiraly L. (2003) Karstification and groundwater flow. Speleogenesis and evolution of karst aquifers. 1(3):1-26.

Mangin A. (1975) Contribution a l'etude hydrodynamique des aquiferes karstiques. Ph.D thesis. Universite de Dijon (Annales de Speleologie 29(3):283-332; 29(4):495-601; 30(1):21-124) (Cited in Geyer 2008). 
MWI (Ministry of Water and Irrigation)-GTZ (German Technical Cooperation (2004) National Water Master Plan, Volume 4: Surface Water Resources, Amman, Jordan.

MWI (Ministry of Water and Irrigation)-GTZ (German Technical Cooperation (2006) Planning Jordan's water future- lesson learnt from the water sector planning support project. Amman, Jordan.

MWI (Ministry of Water and Irrigation) (2011) Water sector country profile-Jordan. Amman, Jordan (unpublished).

MWI (Ministry of Water and Irrigation) (2013a) Jordan water sector facts and figures 2013. First edition. Amman, Jordan.

MWI (Ministry of Water and Irrigation) (2013b) Water budget 2012/2013. National master plan directorate. Amman, Jordan.

Nortcliff S., Black E., Potter R. (2011) Part VI: Society, economy and water today; section 24: Current water demand and future strategies under changing climate condition. In: Mithen S. and Black E. (eds): Water, life and civilisation: climate, environment and society in Jordan valley. Cambridge university press. p. 403-415.

Palmer A. N (1991) Origin and morphology of Limestone caves, Geological Society of American Bulletin.103:1-25.

Smart P.L. and Hobbs S.L. (1986) Characterisation of carbonate aquifers: a conceptual base. Proc. 9th Int. Congr. of Speleology. Barcelona.

Taylor C.J., Greene E.A. (2008) Hydrogeologic characterization and methods used in the investigation of karst hydrology. In: Rosenberry D., LaBaugh J. (eds): Field techniques for estimating water fluxes between surface water and ground water, techniques and methods 4-D2. United States Geological Survey (USGS). Reston, Virginia. p. 75-114.

Treek B. (2007) How can the epikarst zone influence the karst aquifer hydraulic behaviour?. Environ Geol Journal. 51:761-765; doi: 10.1007/s00254-006-0387-x.

UNDP (United Nations Development Programme). Overview about Jordan, Accessed: September 2014. Available from: http://www.jo.undp.org/content/jordan/en/home/countryinfo/. 
Williams P. (2008) The role of the epikarst in karst and cave hydrogeology: a review. International Journal of Speleology. 37(1):1-10.

Zwahlen F., Goldscheider N., Neale S. (2003) Introduction to vulnerability and risk mapping for the protection of carbonate (karst) aquifers. In: Zwahlen F. (eds) COST action 620vulnerability and risk mapping for the protection of carbonate (karst) aquifers. Final report, p. 1-5. 
2. Chapter two: Study area description 


\subsection{Geographical location and topography}

The study area is located in the north eastern part of the Ajloun governorate, about 75 kilometers northwest of the capital city of Amman. The area encompasses the districts Sakhra, Arjan and Qasabet Ajloun. The coordinates of the study area in the World Geographic System (WGS84, decimal degree) are: 35.7390 to 35.8390 east, and 32.3390 to 32.4350 north. Because of the small size of the study area, the Palestine 1923 Palestine Belt coordinate system (in meters) were used as a local coordinate system. The coordinates of the study area in the Palestine 1923 Palestine Belt coordinate system are: 219810 to 229190 east, and 1194120 to 1204680 north. All the maps in this study were prepared using this coordinate system.

Within the study area; three main springs are available and discharging from the same aquifer. The outflow water from the these springs are flowing in Wadi Al-Yabis. These springs are: Tanour, Rasoun, and Beida spring. Table 2-1 representing the coordinates and elevation of these springs. This study will focus mainly on Tanour and Rasoun springs, where they considered as the main drinking water supply source for the surrounding villages, while Beida spring is used just for the agricultural purposes.

Table 2-1: Tanour, Rasoun, and Beida springs coordinates.

\begin{tabular}{|l|c|c|c|}
\hline \multirow{2}{*}{ Spring Name } & \multicolumn{2}{|c|}{ Coordinates (Palestine 1923 Palestine) } & \multirow{2}{*}{ Altitude (m) } \\
\cline { 2 - 3 } & East & North & \\
\hline Tanour Spring & 220420 & 1201618 & 620 \\
\hline Rasoun Spring & 222338 & 1200099 & 749 \\
\hline Beida Spring & 220579 & 1201815 & 626 \\
\hline
\end{tabular}

The study area is topographically characterized as a complex area with steep relief. The elevation within the area ranges between 600-700 m above sea level in the west part and 1100-1200 m above sea level in the southeastern parts. A Digital Elevation Model (DEM) using the ASTER 30 m resolution dataset (USGS 2014a) was embedded in ArcGIS v.10.3 (ESRI @, 1999-2014) in order to calculate flow directions, flow accumulations, and the stream network by using a stream initiation area of 600 acres. The surface water catchment area for both the Tanour and Rasoun springs was determined by assuming the spring heads as outlet points. The Rasoun spring catchment area is considered as a sub-catchment from the Tanour spring catchment area. The 
total size of the catchment area is around $36 \mathrm{~km}^{2}$. Figure 2-1 represents the location map of the study area, and the location of Tanour, Rasoun and Beida springs, and Figure 2-2 shows a 3-D overview of the catchment area of Tanour and Rasoun springs based on the ASTER DEM and by using Surfer software (Golden software (C) 2015).

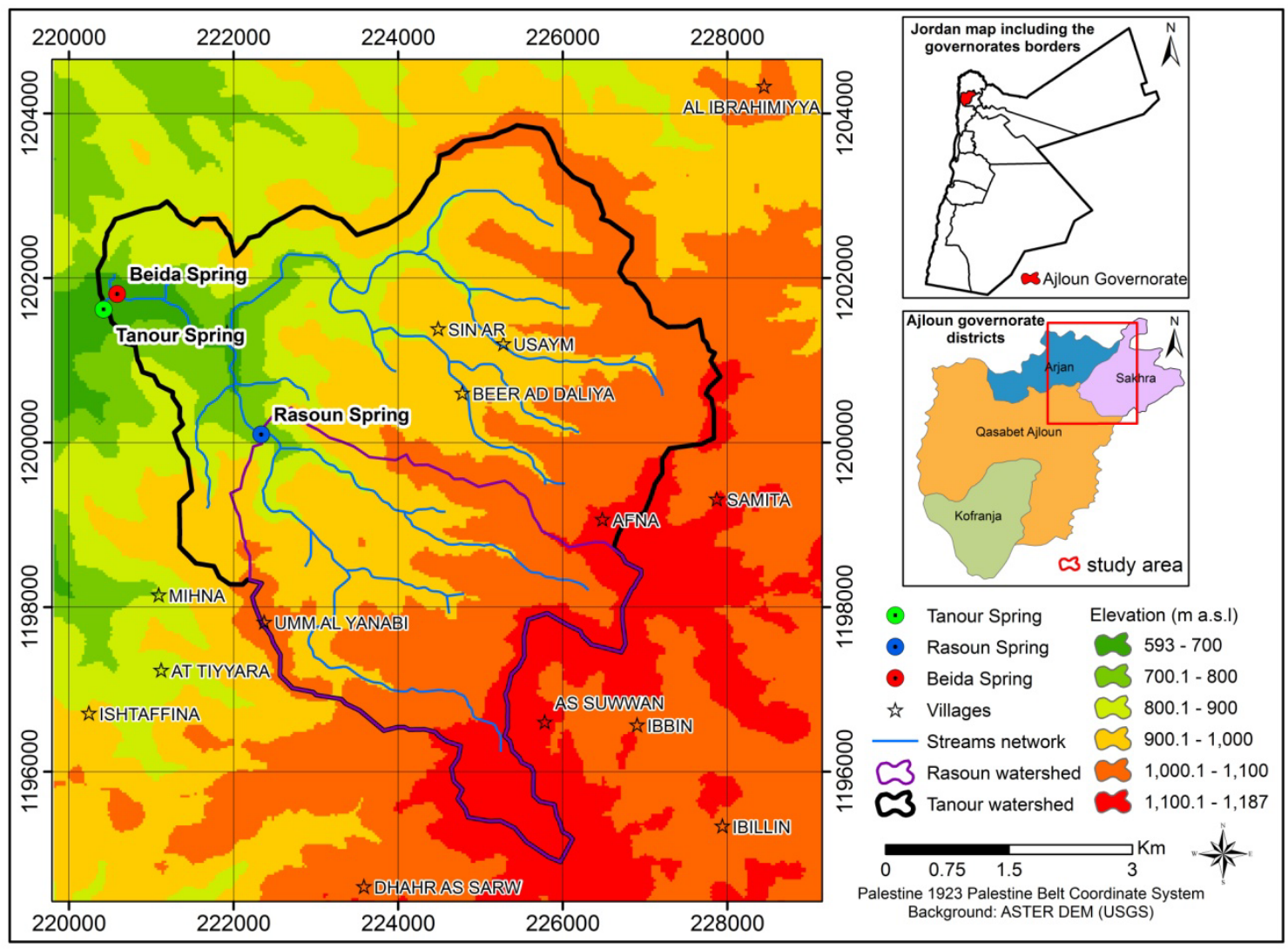

Figure 2-1: General overview location map for the study area. Background taken from ASTER DEM 30 m resolution (USGS 2014a), "ASTER GDEM is a product of METI and NASA". 


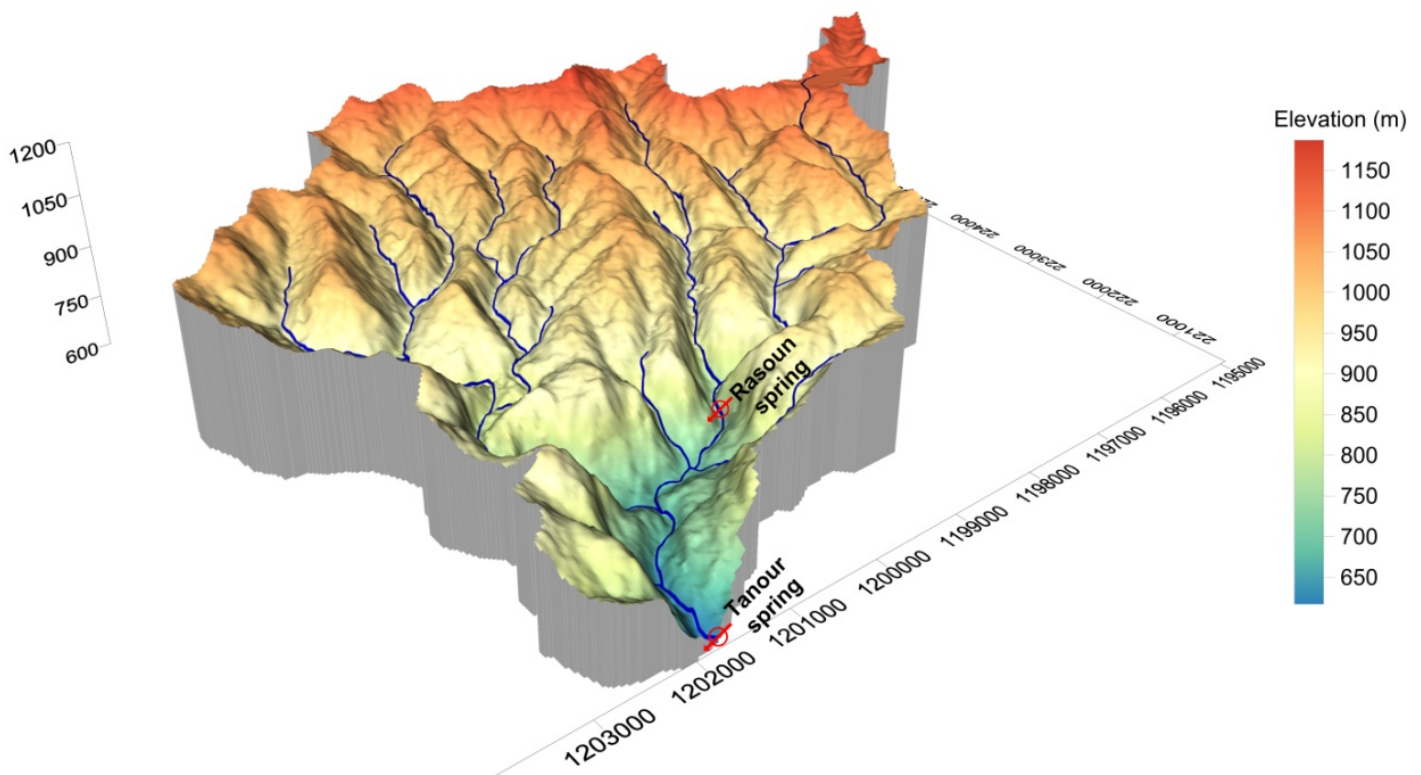

Figure 2-2: 3-D overview map of the catchment area of the Tanour and Rasoun springs.

\subsection{Climate}

\subsubsection{Rainfall}

The climate of the study area is considered as Mediterranean with frequent rain and snowfall events during the winter months. There are four rainfall stations owned and operated by the Ministry of Water and Irrigation (MWI) located within and in the surroundings of the study area. These stations are:

1. AD0018: Ibbin Station

2. AF0002: Rihaba Station

3. AH0001: Ishtafeina Station

4. AH0003: Ras Munif Station (this station located in the southeastern borders of the catchment area) 
Based on daily rainfall data of those rainfall stations (MWI 2014a) for the time period 1961/1962-2013/2014 (water years), Figure 2-3 represents the calculated long-term average monthly values, while Table 2-2 lists the calculated long-term average yearly rainfall amounts.

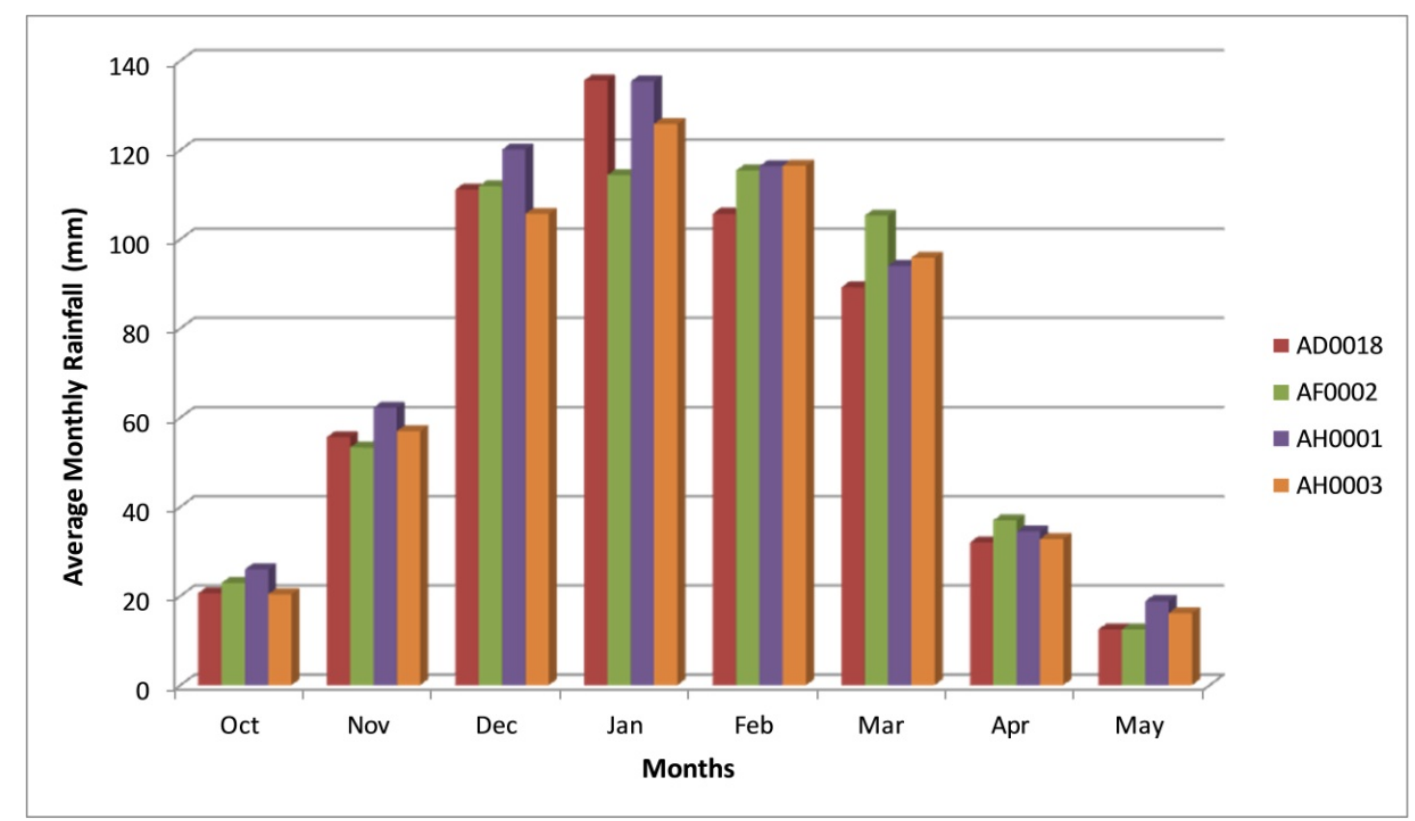

Figure 2-3: The calculated long-term average monthly rainfall distribution for the time period 1961/1962 - 2013/2014 (water year).

Table 2-2: The calculated long-term average yearly rainfall amounts for the time period 1961/1962 - 2013/2014 (water year).

\begin{tabular}{|c|c|}
\hline Station ID & $\begin{array}{c}\text { Long-term yearly average data for the period } \\
\mathbf{1 9 6 1 / 1 9 6 2} \mathbf{- 2 0 1 3 / 2 0 1 4}\end{array}$ \\
\hline AD0018 & 521.4 \\
\hline AF0002 & 537.0 \\
\hline AH0001 & 562.5 \\
\hline AH0003 & 545.7 \\
\hline
\end{tabular}

Based on the calculated long-term average monthly rainfall, the average long-term annual rainfall of the study area ranges between 520 and $560 \mathrm{~mm} / \mathrm{yr}$. 


\subsubsection{Evaporation and Temperature}

Long-term historical data from Ras Munif meteorological station (AH0003) between 1969 and 2013 (MWI 2014b, JMD 2014) for daily pan-A evaporation, minimum and maximum temperature were used. Based on that, the average annual pan-A evaporation is $2058 \mathrm{~mm} / \mathrm{yr}$. Figure 2-4 illustrates the calculated annual pan-A evaporation values for the time period between 1969 and 2013. The average long-term monthly pan-A evaporation (Figure 2-5) for the same time period (1969-2013) shows that the lowest monthly evaporation occurred in the study area between the months of December and January and was around 65-75mm, compared with 280$300 \mathrm{~mm}$ during the months of June and July.

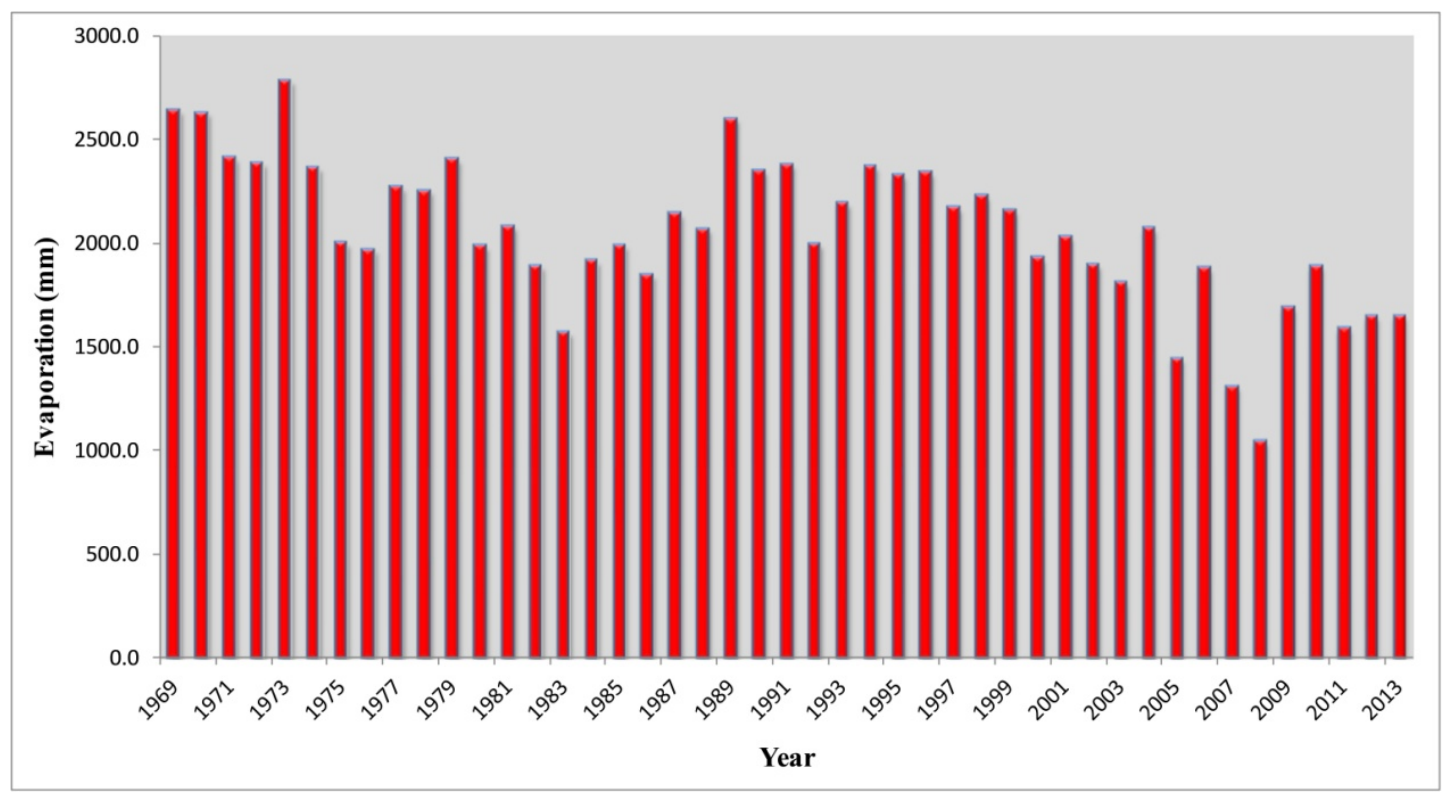

Figure 2-4: Annual pan-A evaporation values measured at AH0003 meteorological station for the time period between 1969 and 2013. 


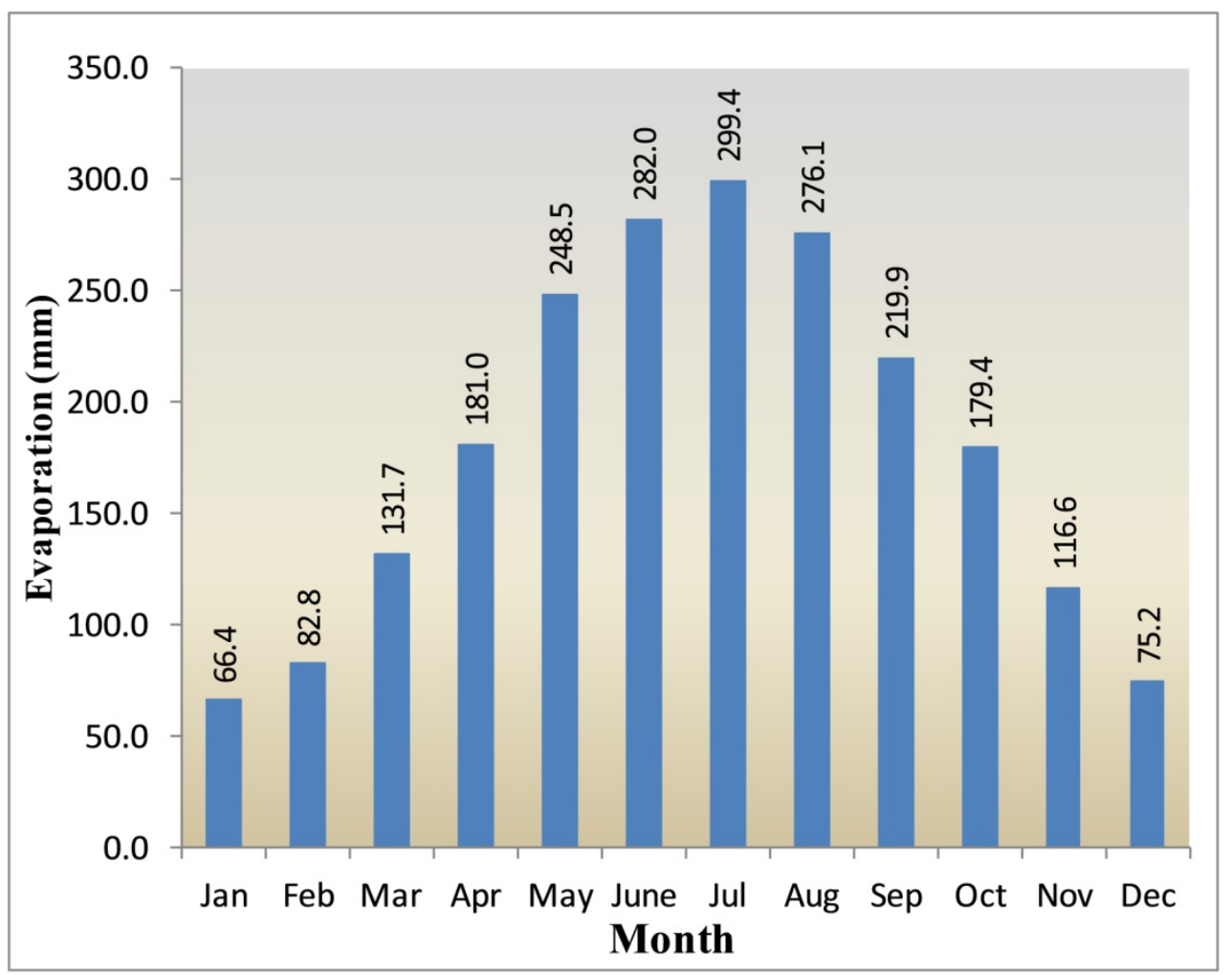

Figure 2-5: Long-term average monthly pan-A evaporation values measured at AH0003 meteorological station for the time period between 1969 and 2013.

Based on the historical minimum and maximum temperature data from the meteorological station AH0003 for the time period between 1969 and 2013 (MWI 2014b, JMD 2014), the monthly average minimum temperatures in the study area vary between 2.5 and $4.5{ }^{\circ} \mathrm{C}$ in the winter season (December and January) and reach around $16{ }^{\circ} \mathrm{C}$ during the summer season (July and August). On the other hand, the long-term average maximum monthly temperature is around $8-10^{\circ} \mathrm{C}$ between December and February and reaches around $27^{\circ} \mathrm{C}$ in July and August. Figure 2-6 represents the long-term monthly average minimum and maximum temperatures measured from the station AH0003. 


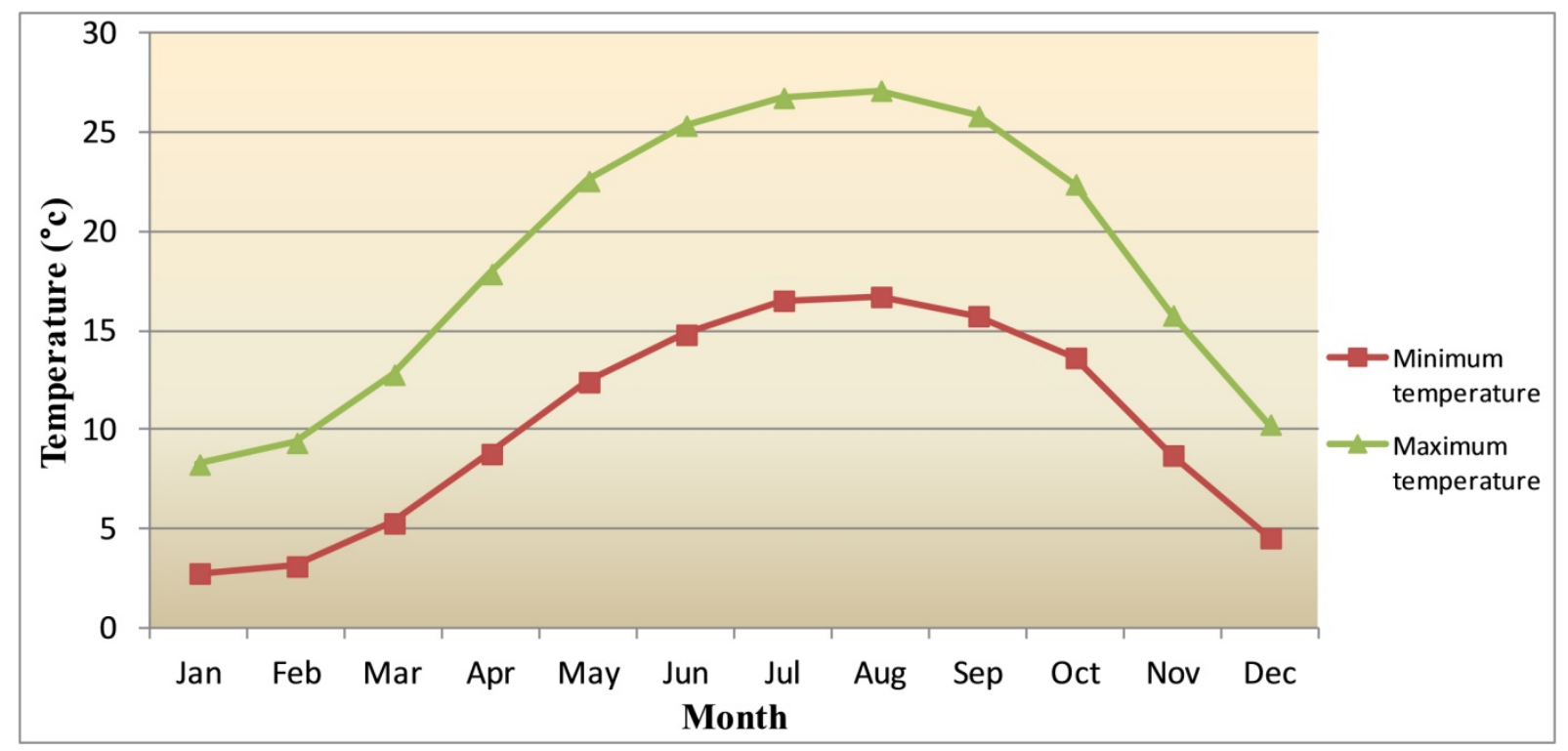

Figure 2-6: Long-term monthly average minimum and maximum temperature for the station AH0003 for the time period between 1969 and 2013.

\subsection{Land cover classification}

A land cover map for the study area was produced using a Landsat 8 OLI/TIRS satellite image. Landsat 8 image No: LC81740382014124LGN00 (USGS 2014b) for the area launched in 04.05.2014 was downloaded (the cloud cover was chosen to be less than 10\%). Different types of calculations and conversions were applied on the Landsat 8 image bands using ArcGIS in order to have a final multi-band Landsat 8 satellite image. All the applied calculations and conversions are presented in Annex 1.

Supervised classification has been applied on the Landsat 8 satellite image using ArcGIS 10.3 image analysis and image classification tools in order to produce a classified land cover map for the study area. Interactive supervised classification was used for producing the land cover map. For this purpose, more than 50 training polygons were determined for each land cover type with the help of Google earth satellite imagery (@ 2015 Google Inc.) of the study area to cross-check the land cover types where the Google earth image resolution is higher than Landsat 8. For the study purposes, three different types of land cover were classified (Figure 2-7): (1) Forests and dense tree areas, (2) Urban areas, and (3) Bare, low and very low dense tree areas. The third land 
cover type includes these types together because it was very difficult to distinguish the spread trees from the bare areas, especially given that the resolution of the satellite image is rather low (15 m), which is insufficient to distinguish the spread trees.

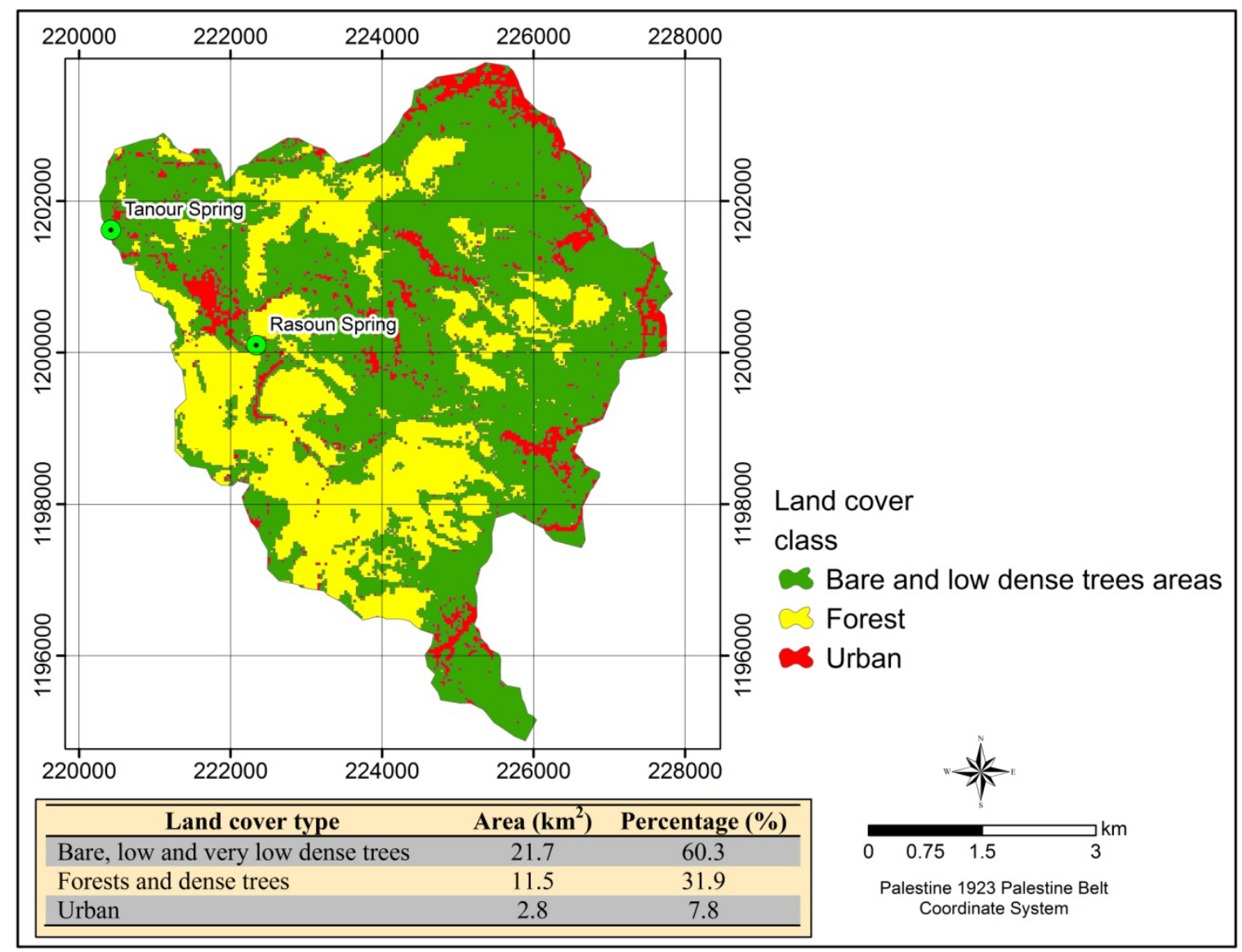

Figure 2-7: Supervised land cover map for the catchment area.

\subsection{Soil}

Based on the national soil map and land use project (the soils of Jordan (level 2)) which has been created by the Ministry of Agriculture (1994), there are four soil units in the study area (Figure 2-8), which are: NW07, NW10, NW17 and NW23, besides the urban areas. Table 2-3 provides a description for these soil units. 


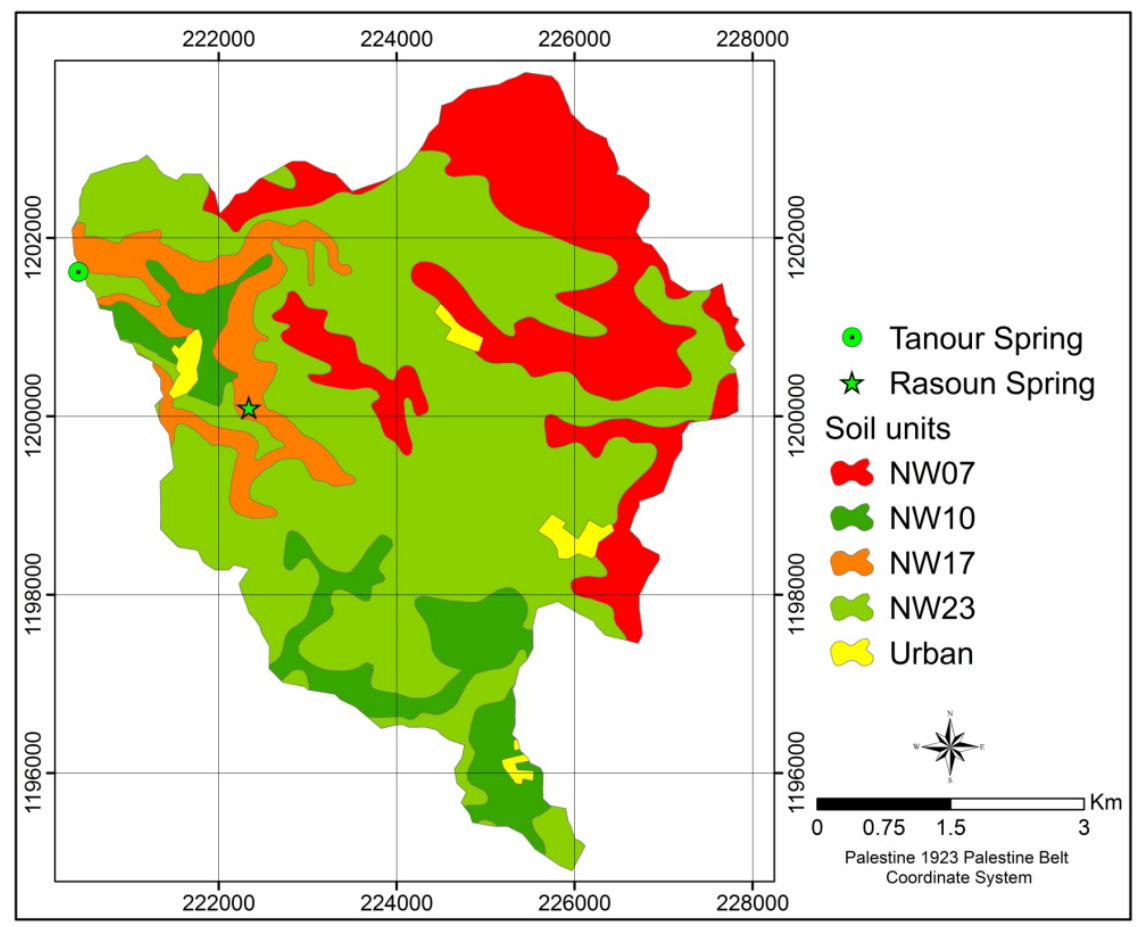

Figure 2-8: Soil unit map within the catchment area (level 2) (modified after Ministry of Agriculture 1994).

Table 2-3: Soil unit description (level 2) within the study area, and soil taxonomy for each subgroup (Ministry of Agriculture 1994).

\begin{tabular}{|c|c|c|c|c|c|}
\hline $\begin{array}{l}\text { Soil } \\
\text { unit }\end{array}$ & $\begin{array}{l}\text { USDA soil } \\
\text { moisture } \\
\text { regime }\end{array}$ & $\begin{array}{l}\text { USDA sub-group/(\%) } \\
\text { series dominant }\end{array}$ & $\begin{array}{c}\text { Clay (\%) } \\
\text { overall }\end{array}$ & $\begin{array}{c}\text { CEC/clay } \\
\text { ratio } \\
\text { overall }\end{array}$ & $\begin{array}{l}\text { Unit average } \\
\text { thickness }\end{array}$ \\
\hline \multirow[t]{3}{*}{ NW07 } & \multirow[t]{3}{*}{ Xeric (wet) } & Typic Xerochrepts/25\% & 37.5 & 0.6 & \multirow[t]{3}{*}{$75 \mathrm{~cm}$} \\
\hline & & Vertic Xerochrepts/15\% & 43 & 0.7 & \\
\hline & & Lithic Xerochrepts/10\% & 38 & 0.7 & \\
\hline \multirow[t]{4}{*}{ NW10 } & \multirow[t]{4}{*}{ Xeric (wet) } & Typic Xerochrepts/60\% & 37.5 & 0.6 & \multirow[t]{4}{*}{$71 \mathrm{~cm}$} \\
\hline & & Vertic Xerochrepts/10\% & 43 & 0.7 & \\
\hline & & Lithic Xerorthents/10\% & 29.5 & 0.7 & \\
\hline & & Lithic Xerochrepts/10\% & 38 & 0.7 & \\
\hline \multirow[t]{4}{*}{ NW17 } & \multirow[t]{4}{*}{ Xeric (wet) } & Typic Xerochrepts/30\% & 37.5 & 0.6 & \multirow[t]{4}{*}{$61 \mathrm{~cm}$} \\
\hline & & Lithic Haploxerolls/15\% & 44.4 & 0.8 & \\
\hline & & Lithic Xerochrepts/15\% & 38 & 0.7 & \\
\hline & & Lithic Xerorthents/10\% & 29.5 & 0.7 & \\
\hline \multirow[t]{4}{*}{ NW23 } & \multirow[t]{4}{*}{ Xeric (wet) } & Lithic Xerochrepts/15\% & 38 & 0.7 & \multirow[t]{4}{*}{$49 \mathrm{~cm}$} \\
\hline & & Typic Xerochrepts/20\% & 37.5 & 0.6 & \\
\hline & & Lithic Xerorthents/20\% & 29.5 & 0.7 & \\
\hline & & Lithic Haploxerolls/10\% & 44.4 & 0.8 & \\
\hline
\end{tabular}




\subsection{Tanour and Rasoun spring characteristics}

Both Tanour and Rasoun springs are considered as the main local domestic water supply for the surrounding villages. Within each spring there is a pumping station with a chlorination unit. The springs are fenced and it is not allowed to enter without permission, except for the operator and related personnel from the ministry of water and irrigation. Figure 2-9 and Figure 2-10 represent schematic diagrams for both the Tanour and Rasoun springs, respectively.

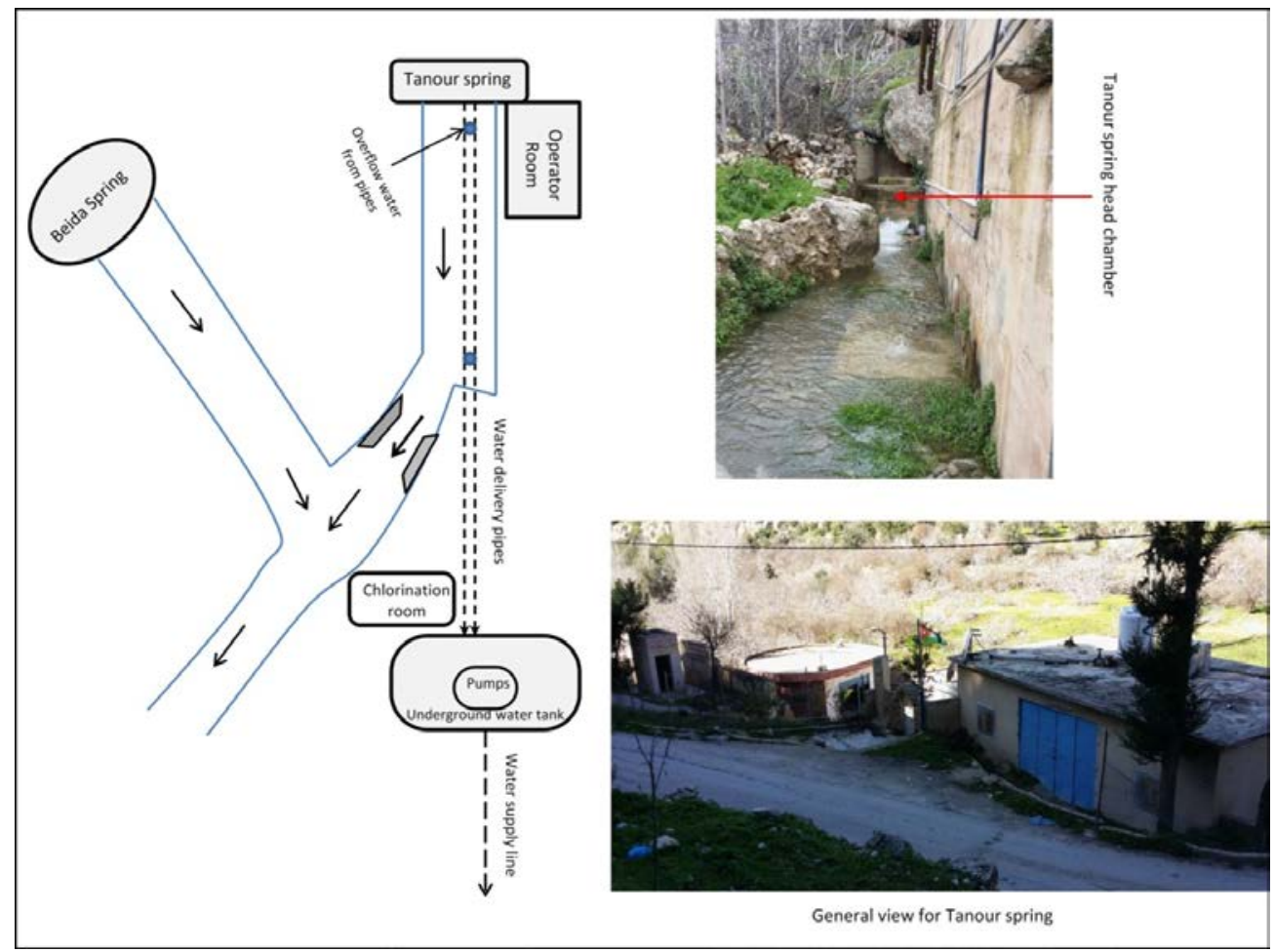

Figure 2-9: Schematic diagram for Tanour spring (photos source: Ibraheem Hamdan). 


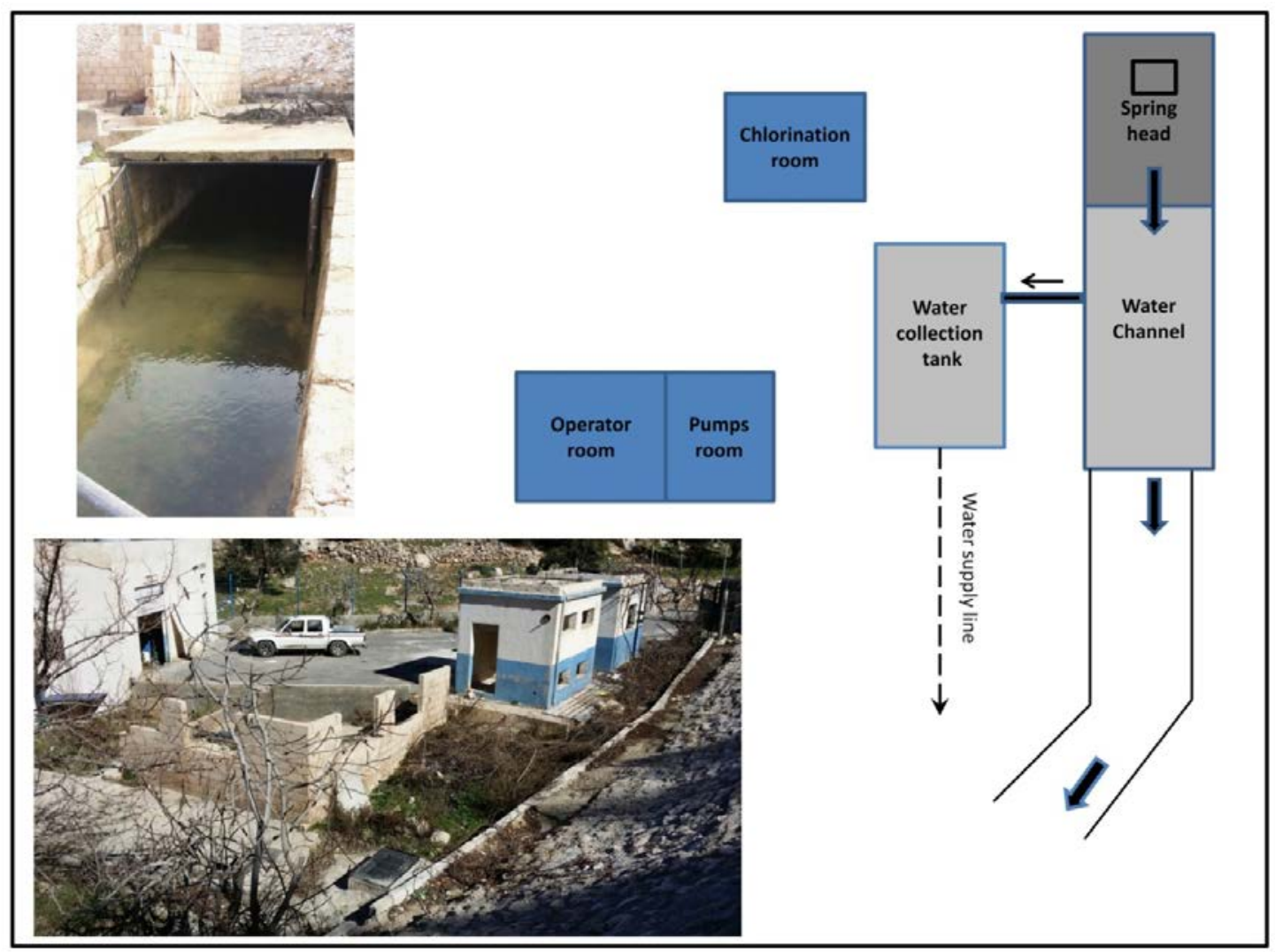

Figure 2-10: Schematic diagram for Rasoun spring (photos source: Ibraheem Hamdan).

On the other hand, a third spring in the catchment area called "Beida spring" is used just for agricultural purposes either by pumping the water from the spring in tanks and moving it to another place, or by using the outflow water in the stream. The access to Beida spring is allowed for everyone (Figure 2-11). After around 200-250 m from Beida spring, the outflow from both the Tanour and Beida springs meets at one point and flows in the same wadi branch (directly after the Tanour spring) (Figure 2-12). 


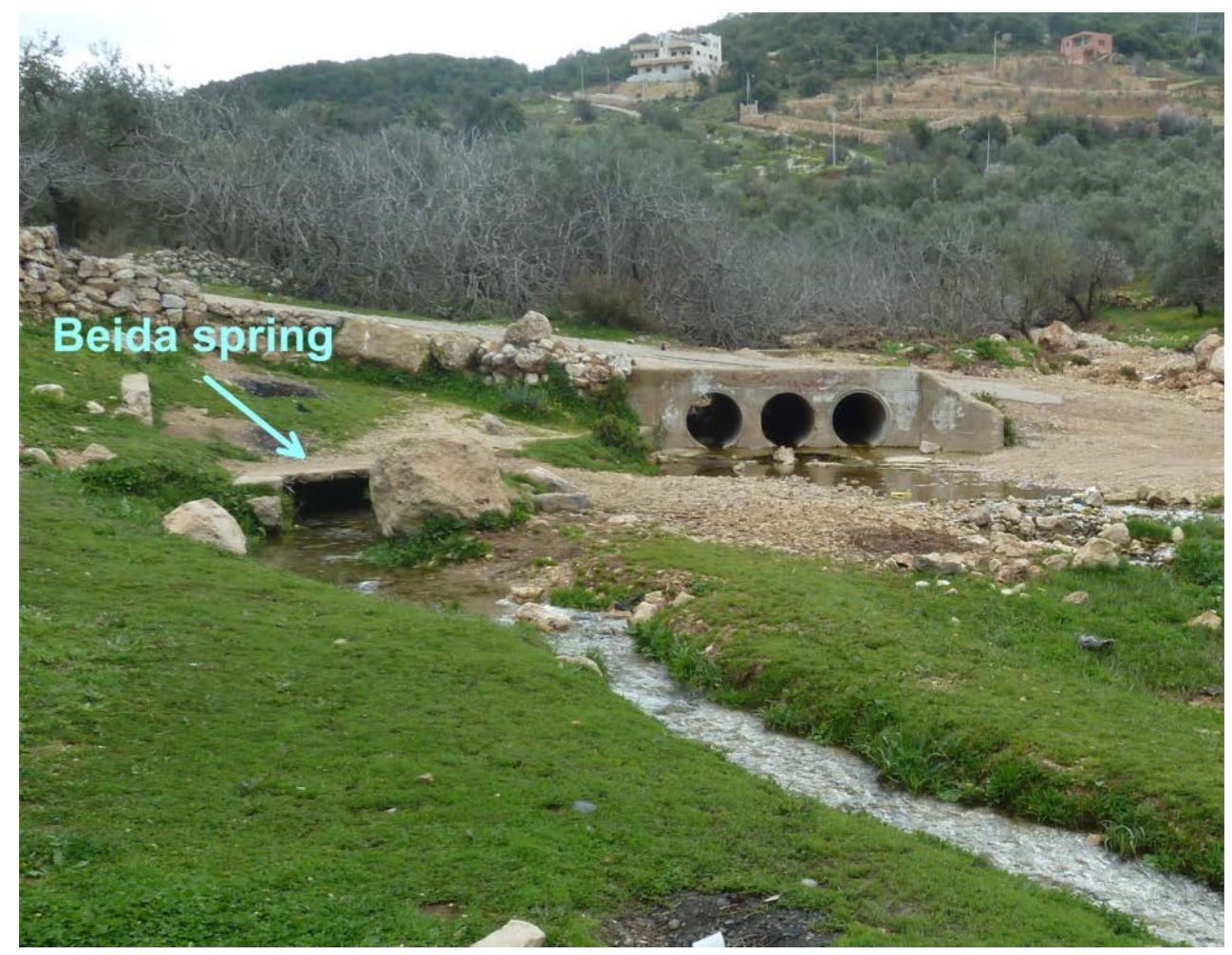

Figure 2-11: General overview for Beida spring (photo source: Ibraheem Hamdan).

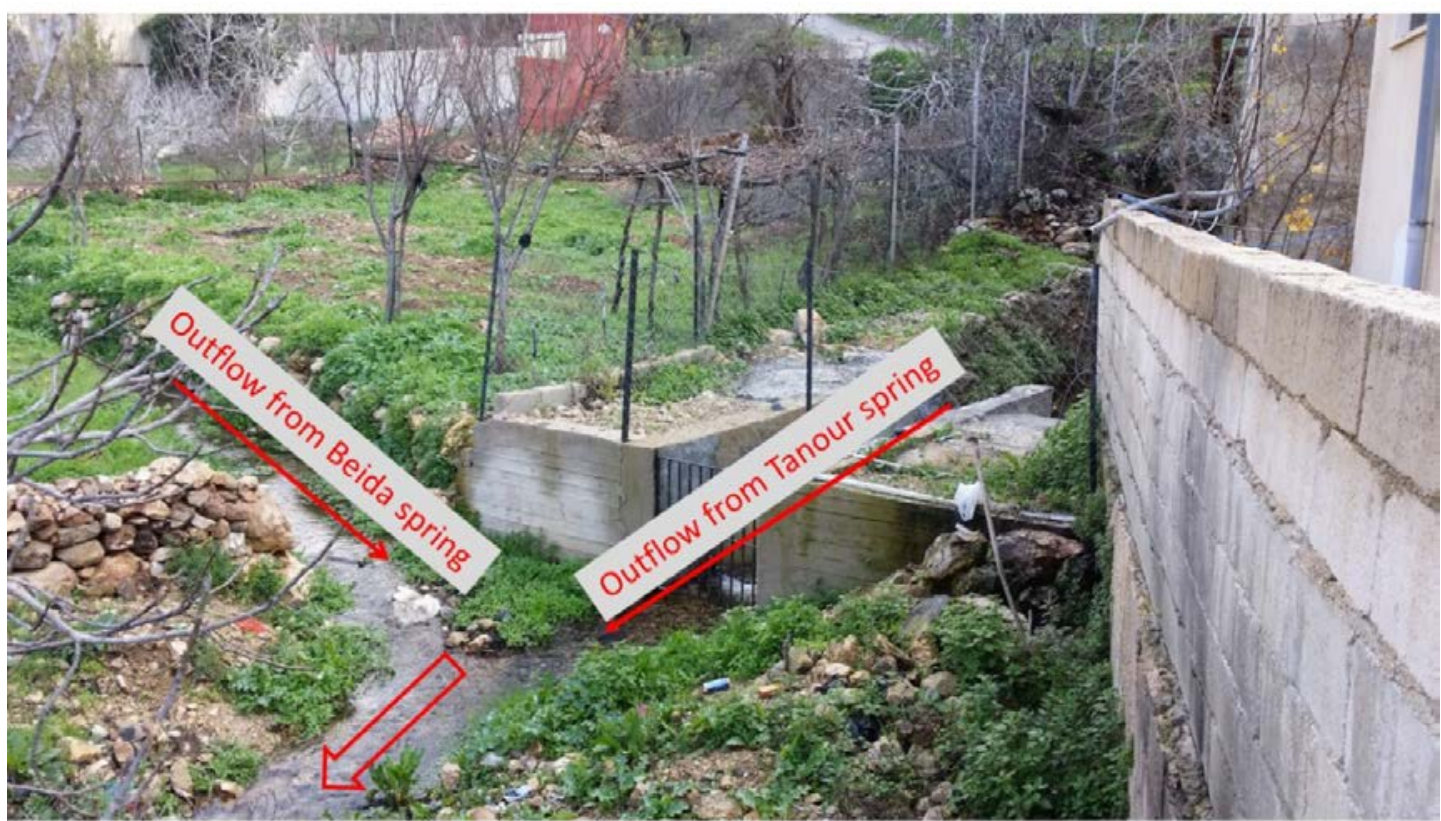

Figure 2-12: Outflow meeting point between Tanour and Beida springs (photo source: Ibraheem Hamdan). 


\subsection{Tanour and Rasoun spring discharge and production}

The spring discharge for the Tanour and Rasoun springs increases dramatically during the winter season after intensive rainfall events, which reflects the behaviour of karst springs. Based on the monthly discharge measurements for the springs (MWI 2015a), Table 2-4 represents the longterm minimum, maximum and average discharge values for the Tanour and Rasoun springs for 1963-2014 (monthly measurements).

Table 2-4: Long-term minimum, maximum and average discharge for Tanour and Rasoun springs, 1963-2014.

\begin{tabular}{|c|c|c|c|c|}
\hline \multirow{2}{*}{ Spring name } & \multirow{2}{*}{ Spring ID } & \multicolumn{3}{|c|}{ Discharge $\left(\mathbf{m}^{\mathbf{3}} / \mathbf{h}\right)$} \\
\cline { 3 - 5 } & & Minimum & Maximum & Long-term average \\
\hline Tanour & AH0510 & 71.6 & 1490 & 259.4 \\
\hline Rasoun & AH0506 & 11.3 & 831 & 89.5 \\
\hline
\end{tabular}

Based on the monthly spring discharge values (MWI 2015a), and daily rainfall data for the meteorological station (AH0003) (MWI 2014a) for the time period 1968/1969-2013/2014 (water year); Figure 2-13 and Figure 2-14 shows the relation between rainfall and spring discharge for the Tanour and Rasoun springs. 


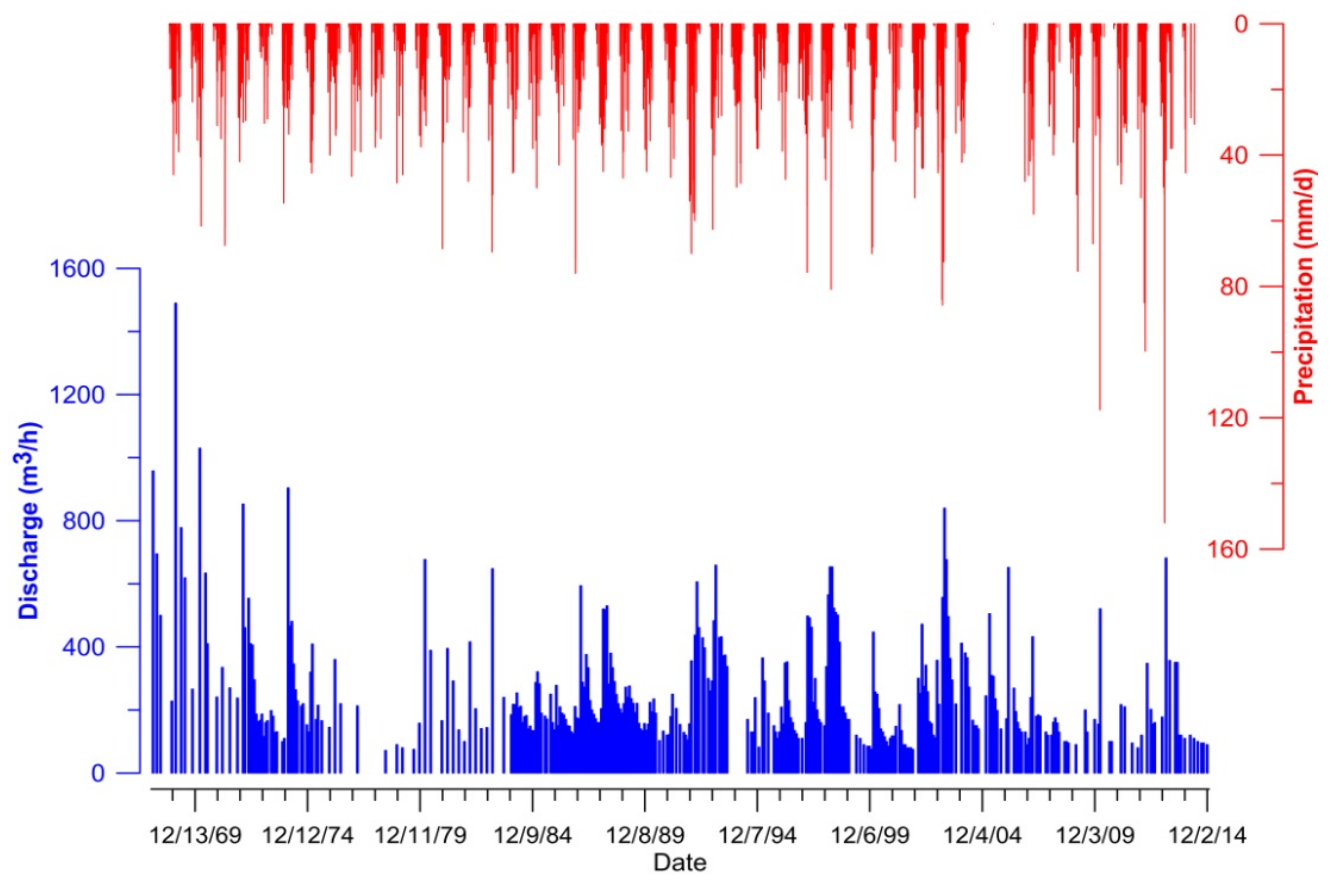

Figure 2-13: Relation between rainfall (Ras Munif station AH0003) and Tanour spring discharge for 1968/1969-2013/2014.

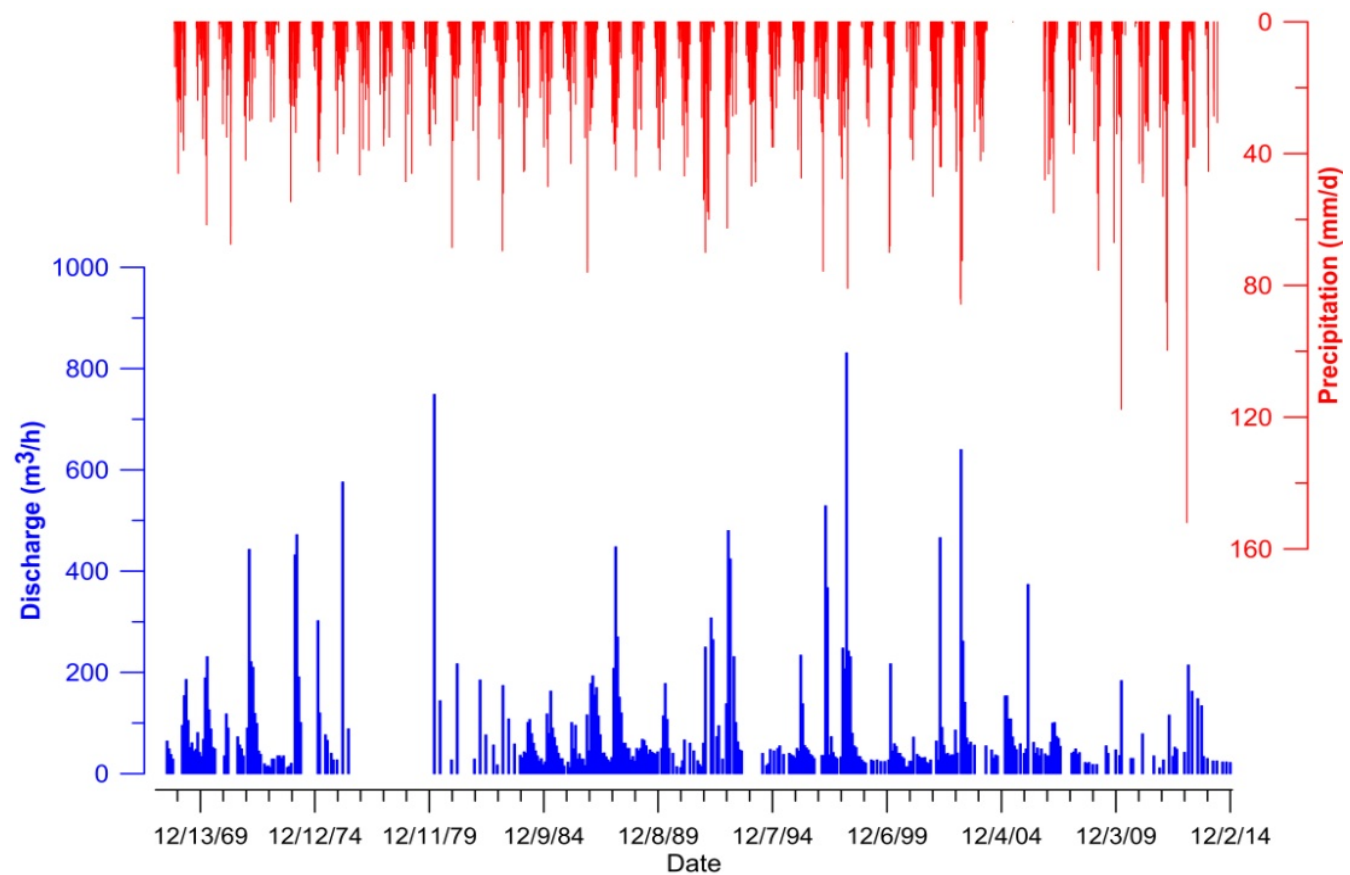

Figure 2-14: Relation between rainfall (Ras Munif station AH0003) and Rasoun spring discharge for 1968/1969-2013/2014. 
Due to the pollution events occurring at the Tanour and Rasoun springs, the water supply from these springs has been interrupted many times within the year from several days to several weeks. Table 2-5 represents the calculated yearly production values from the Tanour and Rasoun springs for 1996-2014 (MWI 2015b: based on the monthly production values).

Table 2-5: Yearly production values from the Tanour and Rasoun springs for 1996-2014.

\begin{tabular}{|c|c|c|c|c|c|}
\hline \multirow{2}{*}{ Year } & \multicolumn{2}{|c|}{ Production Value (m³/yr) } & \multirow{2}{*}{ Year } & \multicolumn{2}{|c|}{ Production Value ( $\left.\mathrm{m}^{3} / \mathrm{yr}\right)$} \\
\hline & Tanour spring & Rasoun spring & & Tanour spring & Rasoun spring \\
\hline 1996 & 1055509 & 132300 & 2006 & 1101930 & 152897 \\
\hline 1997 & 1540645 & 176818 & 2007 & 1270659 & 104789 \\
\hline 1998 & 1737324 & 90480 & 2008 & 1058374 & 101657 \\
\hline 1999 & 988050 & 195027 & 2009 & 1141365 & 80142 \\
\hline 2000 & 1173050 & 150564 & 2010 & 1067456 & 129498 \\
\hline 2001 & 867830 & 155961 & 2011 & 849861 & 86786 \\
\hline 2002 & 1335650 & 100710 & 2012 & 1000185 & 100491 \\
\hline 2003 & 1290570 & 51790 & 2013 & 1204160 & 159478 \\
\hline 2004 & 777525 & 97565 & 2014 & 760841 & 220497 \\
\hline 2005 & 1337698 & 94414 & Average & 1134667 & 125361 \\
\hline
\end{tabular}

\subsection{Geology and structures}

Geological outcropping in the study area is characterized by the upper part of the Ajloun group and the lower part of the Belqa group (both are of Upper Cretaceous age). The main rock types within the study area are limestone, dolomitic limestone, marl and siltstone.

An overview of the study area can be made based on two geological sheets drawn at a scale of 1:50,000 (Natural Resources Authority (NRA), Jordan). The first of these is Jarash geological map sheet No. 3154-I (Abdelhamid 1993) (the majority of the study area is located within this sheet) and the second is Dayr Abu Sa'id geological map sheet No. 3154 IV (Abu Qudaira 2005). Figure 2-15 displays the outcropping geological formations and faults found in the study area. 


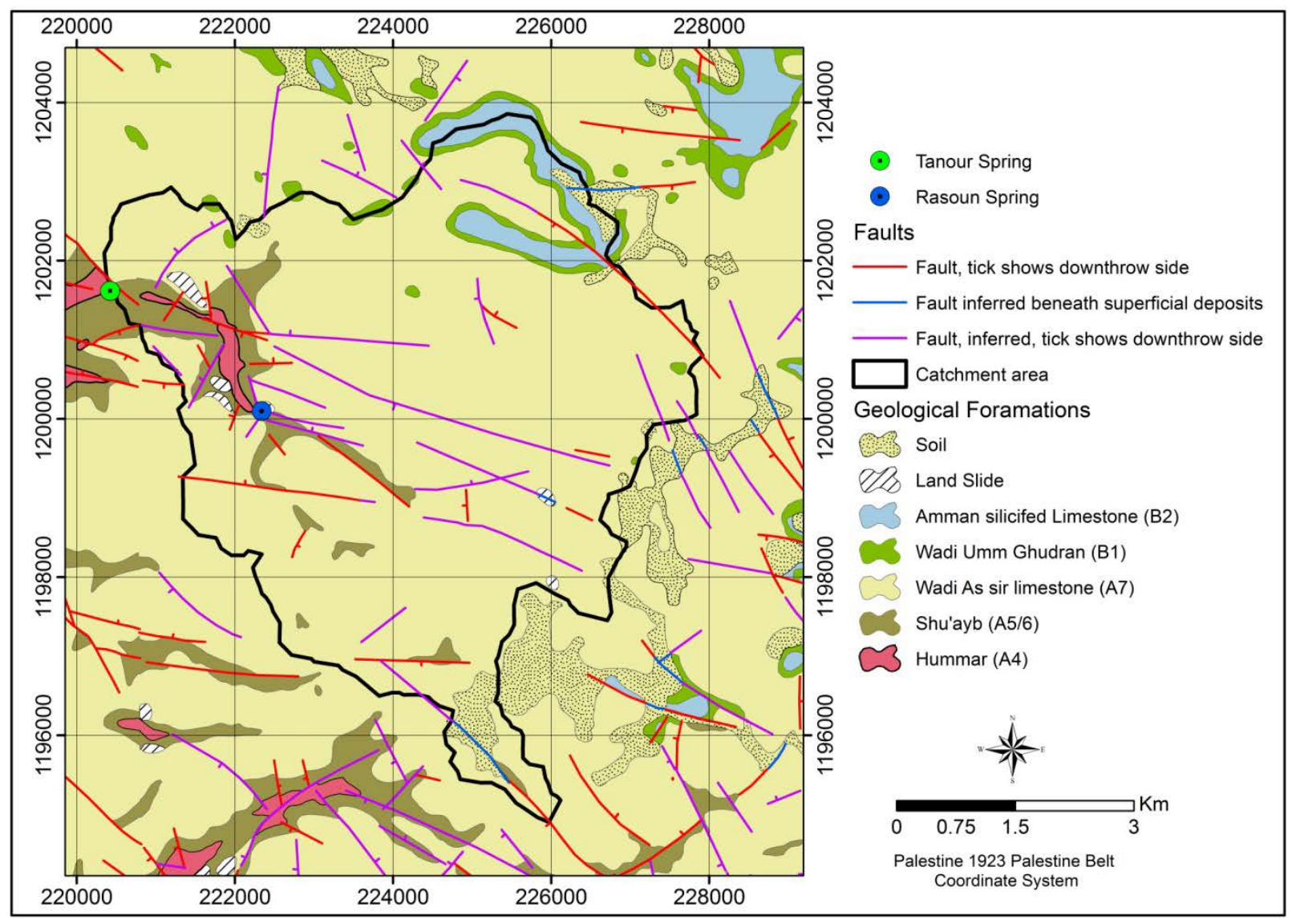

Figure 2-15: Geological map of the study area (modified after Abdelhamid 1993 and Abu Qudaira 2005).

The following geological description is based mainly on data contained in the Jarash geological map sheet (Abdelhamid 1993) and the geology of the Jarash area map sheet bulletin presented by Abdelhamid (1995), as well as other different references will be mentioned within the text. The entire catchment area of the Tanour and Rasoun springs are located within the Jarash sheet.

\subsubsection{Upper part of the Ajloun Group}

The Ajloun group consists of five geological sequences introduced for the first time by Masri (1963). In the study area, only the upper part of the Ajloun group formations were available, in upwards sequence from older to younger: Hummar (A4), Shu'ayb (A5/6) and Wadi as Sir (A7). Figure 2-16 presents a general view of these formations as encountered in the field in the study area. 


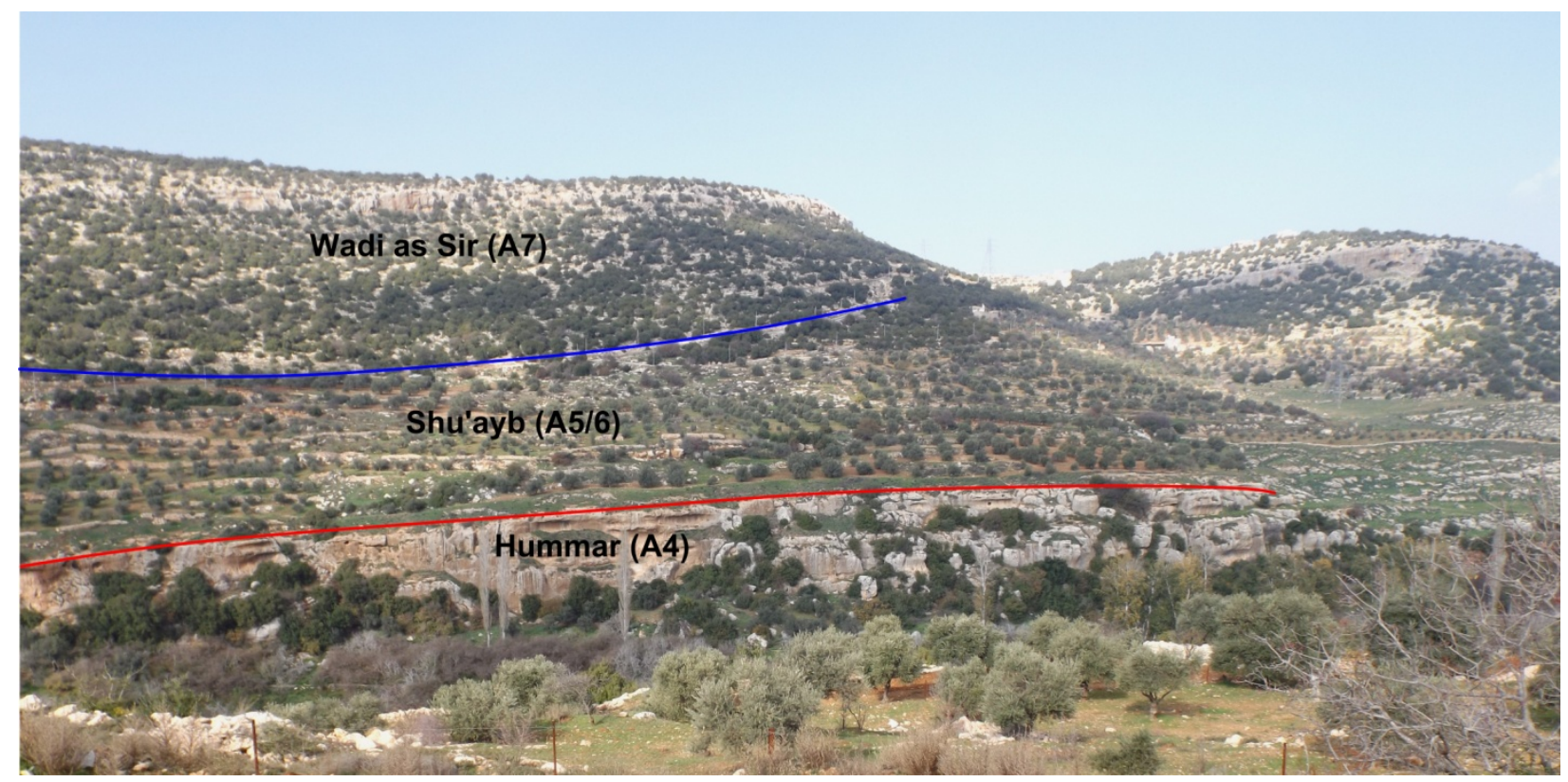

Figure 2-16: Hummar (A4), Shu'ayb (A5/6) and Wadi as Sir geological formation sequence in the study area (photo source: Ibraheem Hamdan).

\section{- Hummar formation (A4)}

According to Abdelhamid (1993; 1995), the Hummar formation consists mainly of pink to yellow-grey limestone, partly crystallized and locally fossiliferous, and partly of dolomitic limestone (Figure 2-17). The average thickness of the Hummar formation in the study area is 40-50 m. Figure 2-18 presents a panoramic view of the site of the Tanour spring within the Hummar (A4) geological formation. 

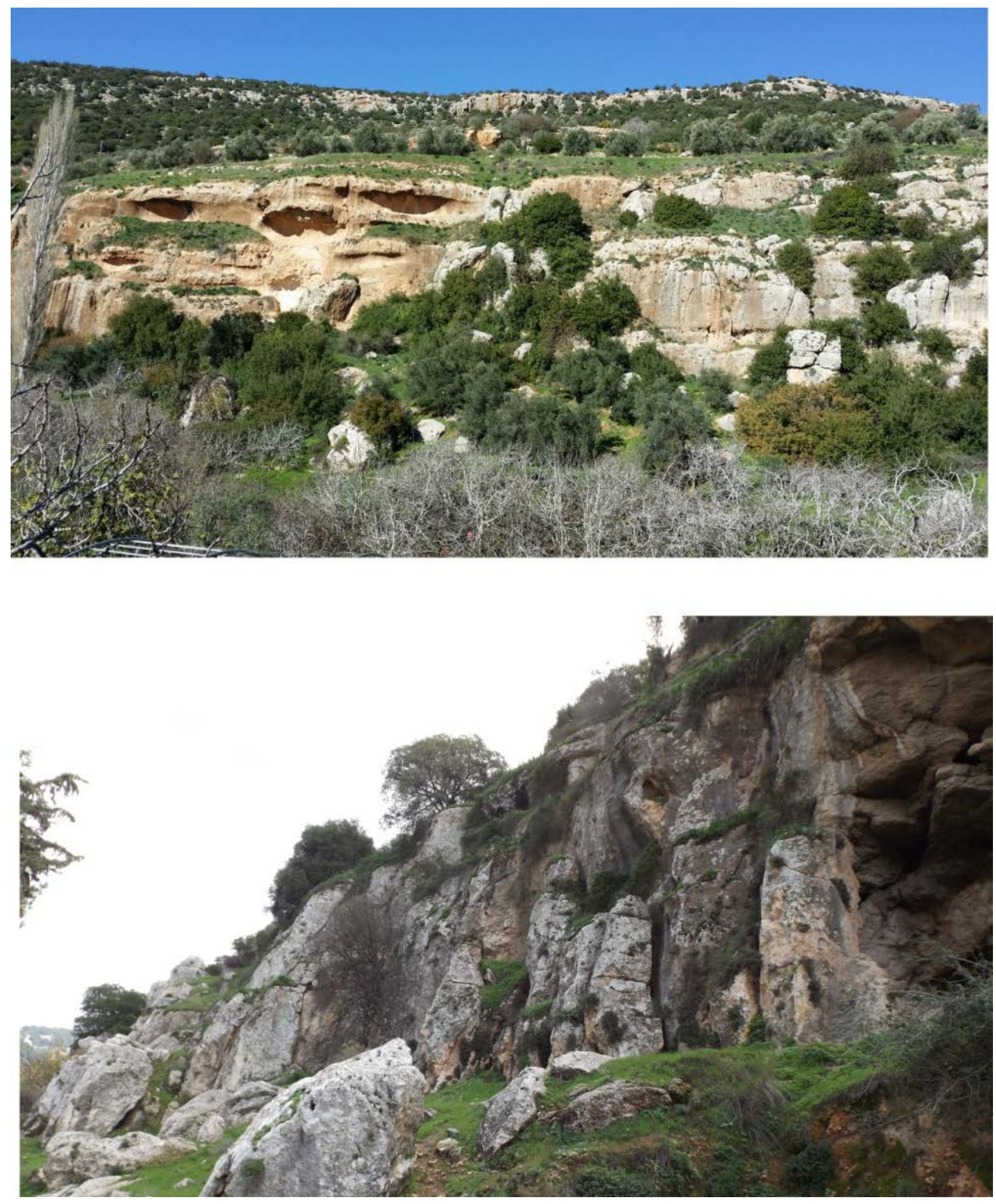

Figure 2-17: Hummar geological formation (A4) outcrop in the study area (photo source: Ibraheem Hamdan). 


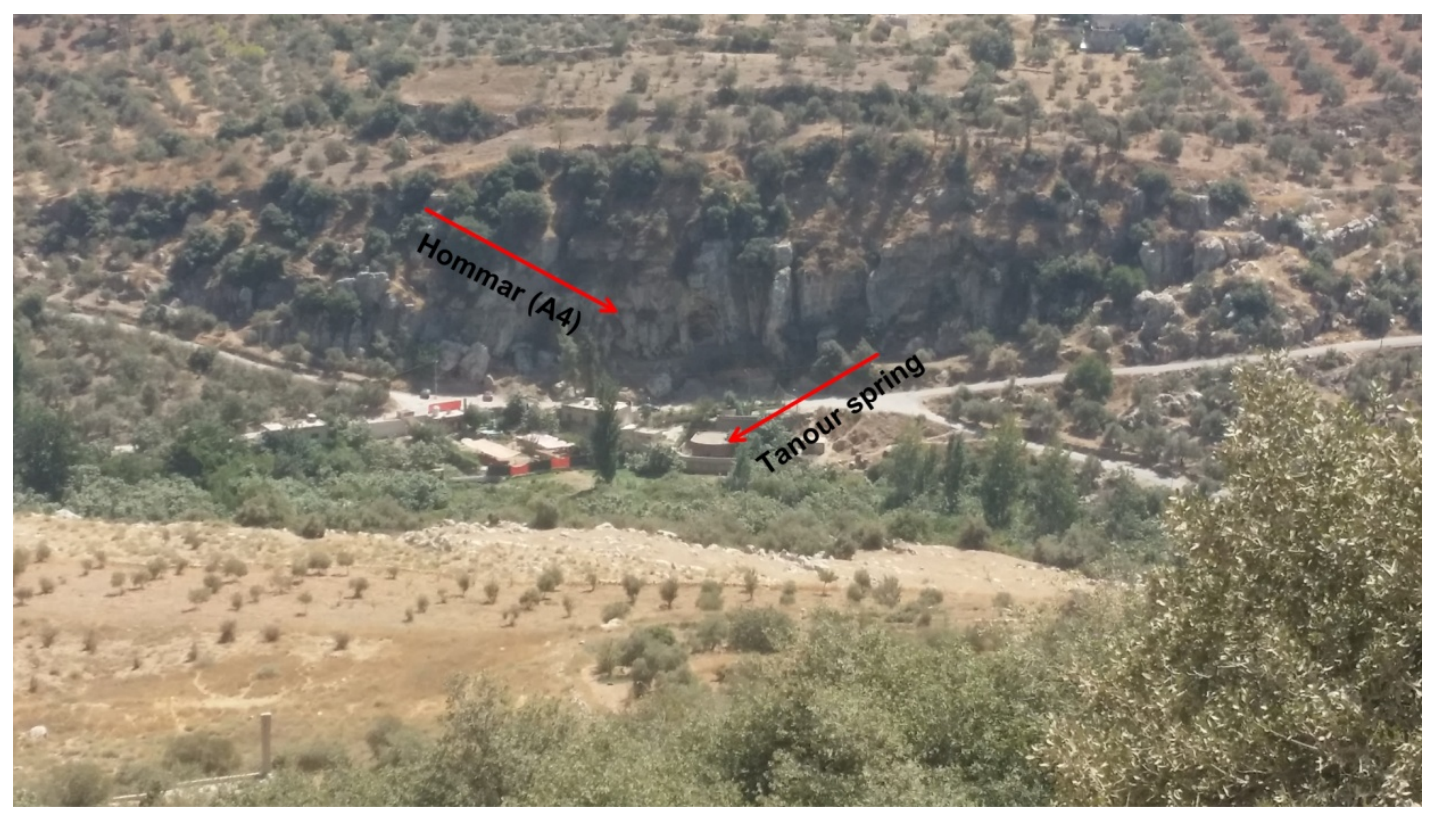

Figure 2-18: Panoramic view of the Tanour spring within the Hummar (A4) geological formation (photo source: Ibraheem Hamdan).

\section{- Shu'ayb Formation (A5/6)}

The Shu'ayb formation within the study area consists of massively crystalline fossiliferous limestone, together with yellow to yellow-grey thin to medium beds of marly limestone and marl (Figure 2-19), with a total thickness varies from 55 to 70 m (Abdelhamid 1993; 1995). 


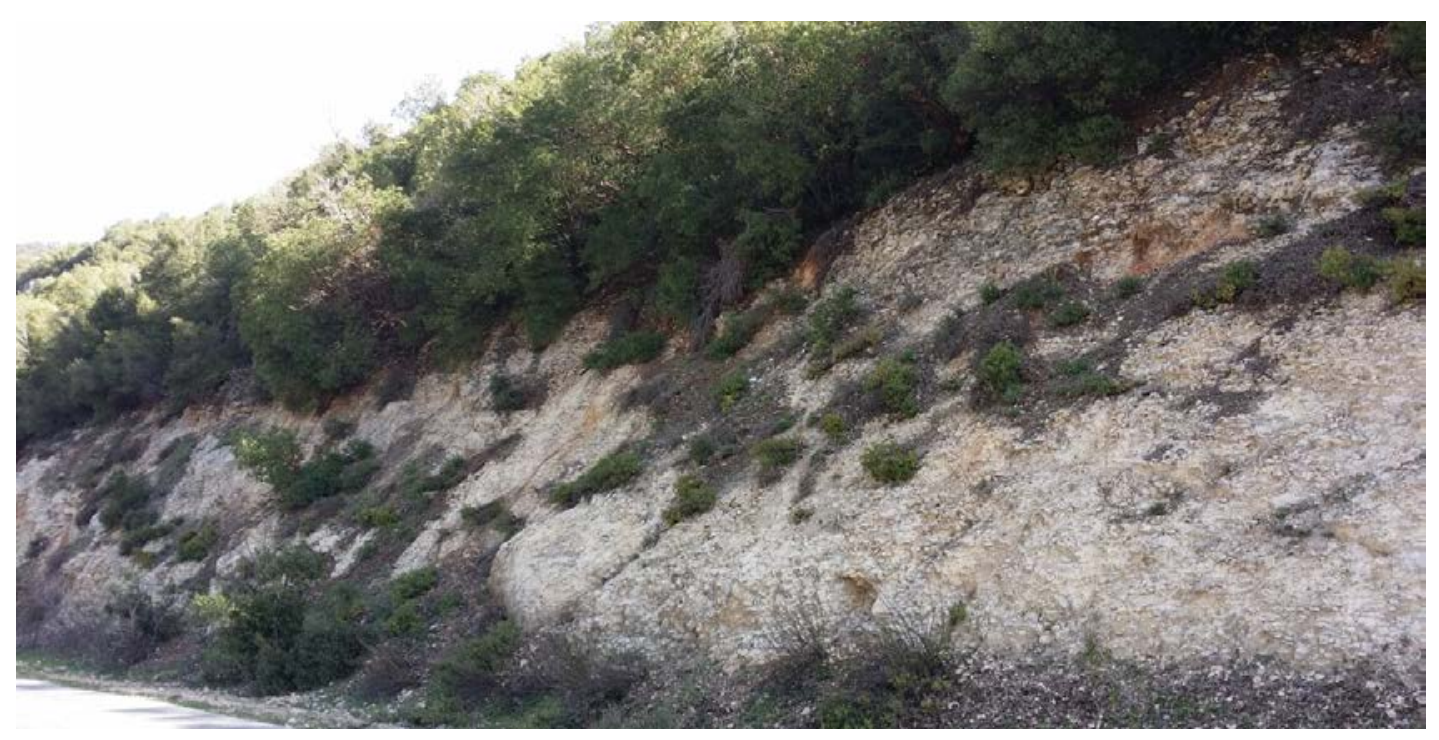

Figure 2-19: Shu'ayb geological formation (A5/6) outcrop in the study area (photo source: Ibraheem Hamdan).

\section{- Wadi as Sir Formation (A7)}

Exposed in wide areas across the study area (Figure 2-20), the Wadi as Sir formation consists of three units: a lower unit consists of dolomite and dolomitic limestone, a middle unit comprising of soft marly limestone and limestone, and an upper unit consisting entirely of thick-bedded to massive limestone (Abdelhamid 1993; 1995). According to Abdelhamid (1995), the thickness of the Wadi as Sir formation varies across the Jerash survey sheet from $70 \mathrm{~m}$ (north of Asfur in the southeast) to $220 \mathrm{~m}$ (just south of Inba in the northwest). Within the study area, lithologies obtained from two wells - well number AD1228 and well number AH3004 (MWI 2014c) - have been used to estimate the thickness of formation A7 within the catchment area at around 120-140 m. Further details regarding estimates of the thickness of the Wadi as Sir (A7) formation in the study area will be discussed later in Section 2.9. 

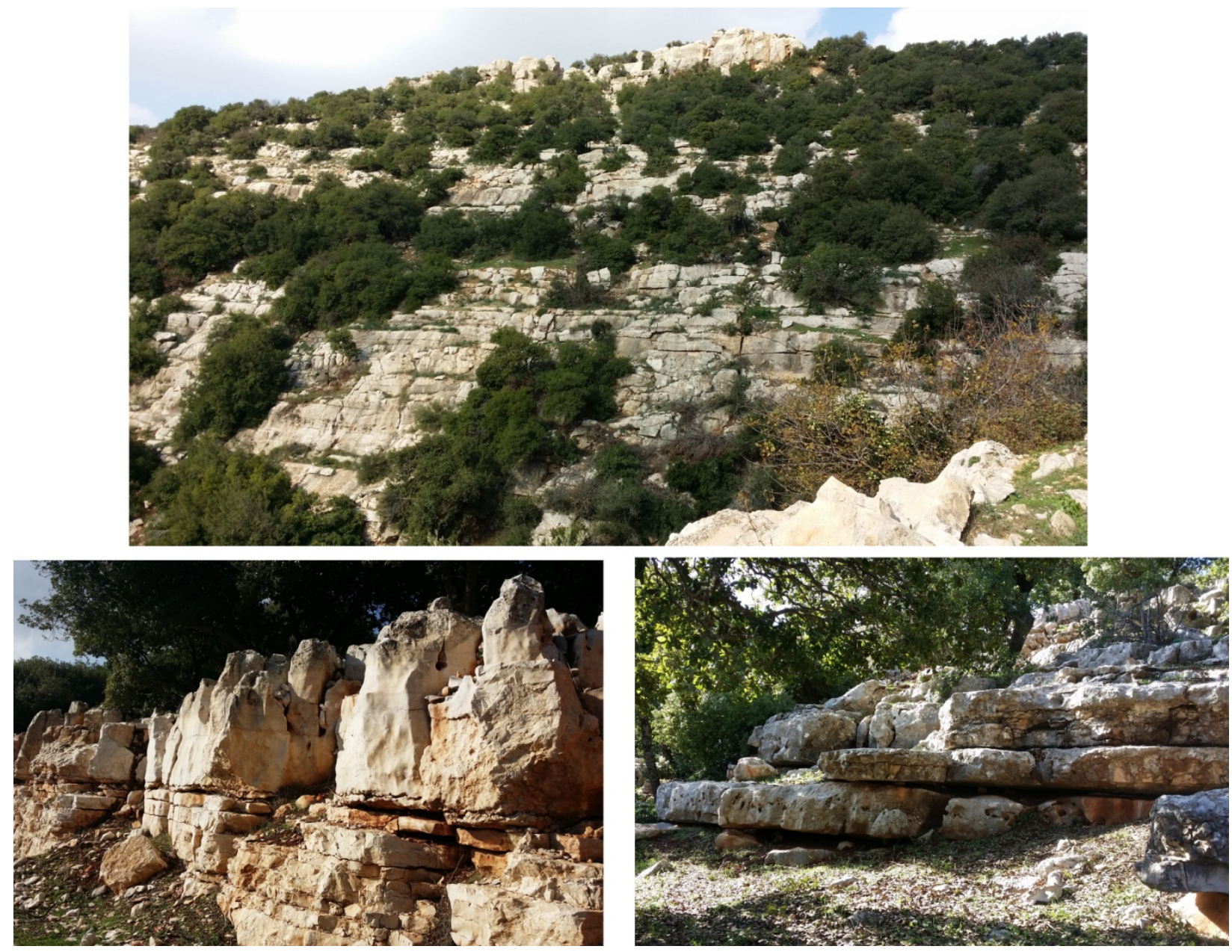

Figure 2-20: Wadi as Sir (A7) geological formation outcrop in the study area (photo source: Ibraheem Hamdan).

\subsubsection{Lower part of the Belqa group}

The Belqa Group overlays the Ajloun Group and consists of five formations, two of them are available in the study area: (1) the Wadi Umm Ghudran (B1) formation and (2) the Amman Silicified Limestone (ASL) formation (B2). Figure 2-21 presents a general example of the B1 and B2 geological formations as they outcrop within the study area.

\section{- Wadi Umm Ghudran (B1)}

Representing the boundary between the Ajloun group and Belqa group, the Wadi Umm Ghudran formation consists of two distinctive parts (lower and upper): a lower part comprising around 15 
m of yellow to white-grey, fragmented and fossiliferous chalky limestone, which marks the unconformity with the underlying Ajloun group. The upper part comprising from around $15 \mathrm{~m}$ of pink to yellow-grey, hard, medium to thin-bedded limestone and chalky limestone (Abdelhamid 1995). The thickness of the Wadi Umm Ghudran formation is around 30-35 m (Abdelhamid 1993).

\section{- Amman Silicified Limestone (B2)}

This formation consists of medium to thin beds of chert, silicified limestone, limestone and phosphatic chert with a total thickness of 60 - 70 m (Abdelhamid 1993; 1995).

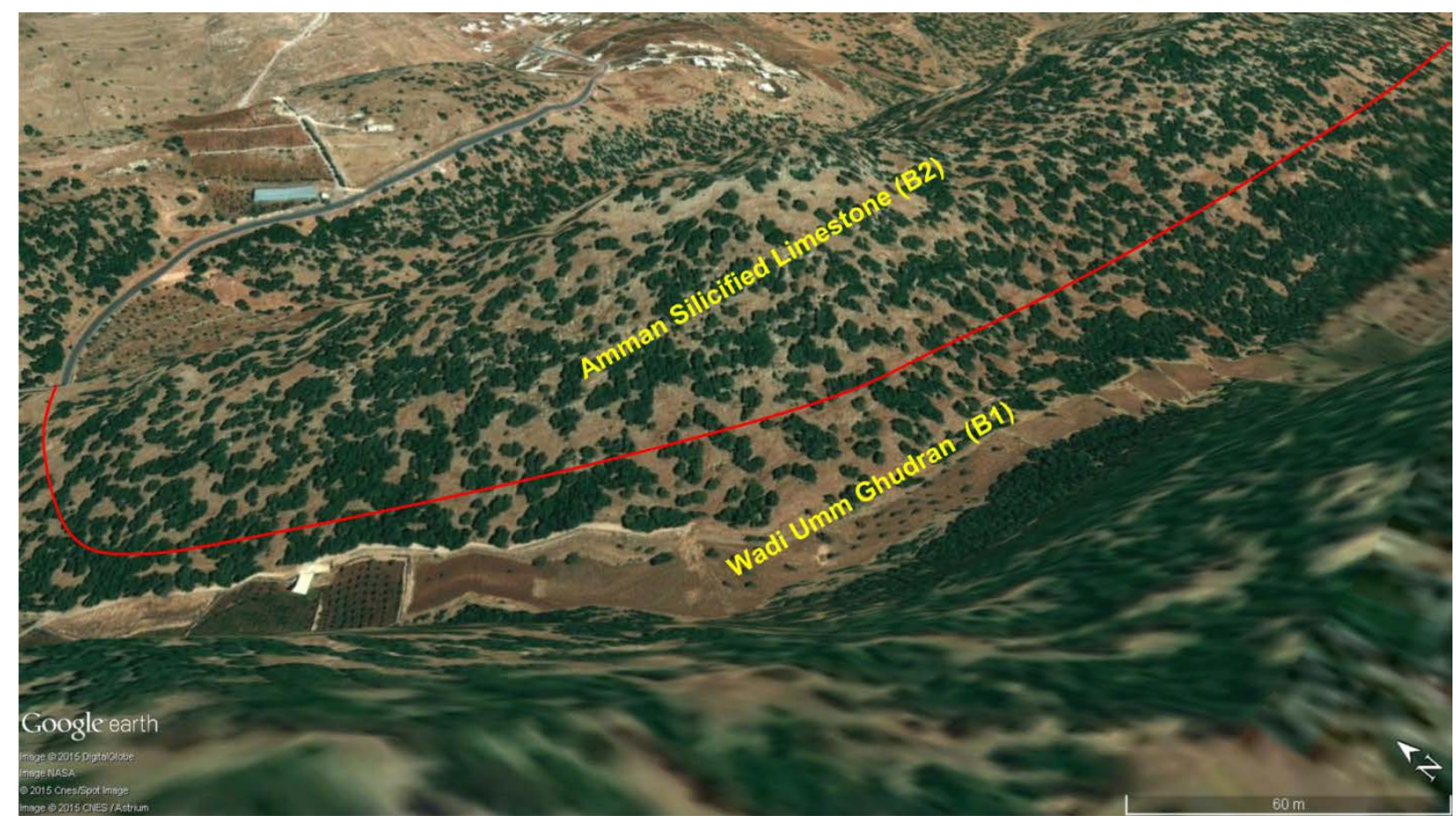

Figure 2-21: Wadi Umm Ghudran (B1) and Amman Silicified limestone (B2) outcrops in the study area (background source:Google Earth image (C), March 2016).

\subsubsection{Structure}

Based on Abdelhamid (1993; 1995), the faults within the area are dominated by a major eastwest fault system, together with less important north-northeast to northeast and northwest faults 
(Figure 2-15). Within the area, most of the folds are gentle with a trend range from ENE and NE to WNW, and folds amplitude ranges from $100 \mathrm{~m}$ to hundreds of metres.

\subsubsection{Available karst features within the catchment area}

The degree of karstification within the limestone rocks in the study area is moderate to high. According to geological survey which have been conducted within the study area, different surface karst features are apparent at various scales, including dolines, caves, a dry valley, highly fractured rocks and karst pavement.

\section{- Dolines}

Often considered diagnostic karst landforms. Based on Goldscheider and Andreo (2007), dolines are defined as "closed, sub-circular depressions, ranging in size from metres to hundreds of metres". Generally, dolines may be formed via the dissolution of carbonate rocks are close to the surface, or by the collapsing of a cave roof (Goldscheider and Andreo 2007, Abi Rizk and Margane 2011). Within the study area, a number of dolines are found at different scales (Figure 2-22).

\section{- Caves}

The term karst caves is defined by Ford and Williams (2007) as "an opening enlarged by dissolution to a diameter sufficient for breakthrough kinetic rates to apply, if the hydrodynamic setting will permit them". Within the study area, many caves of various sizes and shapes are found (Figure 2-23).

\section{- Dry valley}

In karst areas, most drainage takes place below ground, with water percolating into the underground and flowing through conduits. In dry valleys, surface streams flow only after heavy rainfall, when the underground drainage system is unable to cope with the high flow levels (Stokes et al. 2010). Within the study area, a distinctive dry valley is located at around 100-150 
$\mathrm{m}$ from the Rasoun spring. Most of the outflow from this spring disappears within 10-20 m (Figure 2-24).

\section{- Other karst features}

Other types of karst feature are also present in the study area, including kamenitza (pools in the stone surface), highly fractured bedding planes, karst pavement and grikes (vertical joints in the karst). Figure 2-25 depicts some of these features, while Figure 2-26 shows a large-scale karst pavement. 

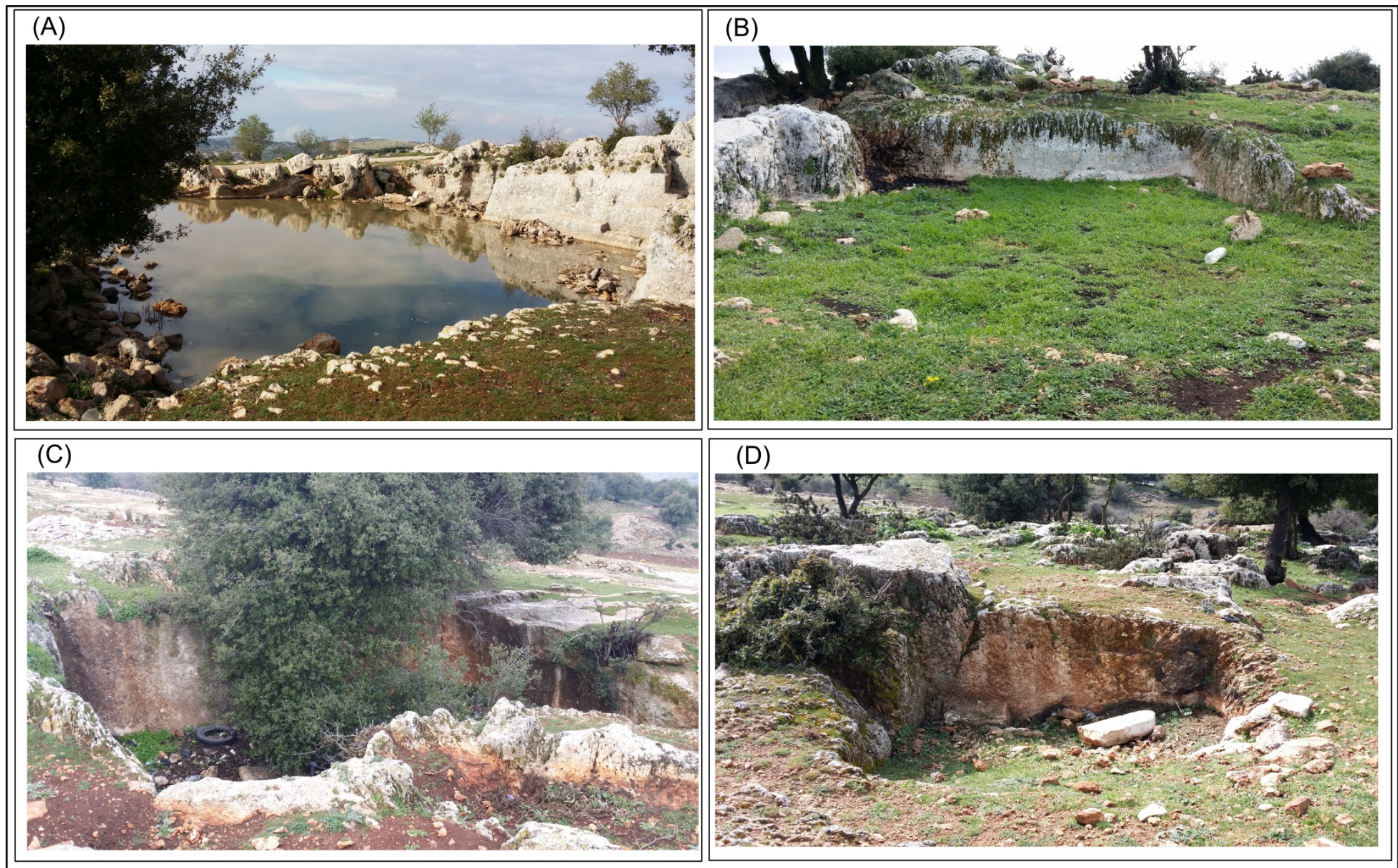

Figure 2-22: Dolines occurring at different scales in the study area: (a) 15*15 m, (b) 7*5 m, (c) 15*10 m, (d) 3*2 m (photo source: Ibraheem Hamdan). 


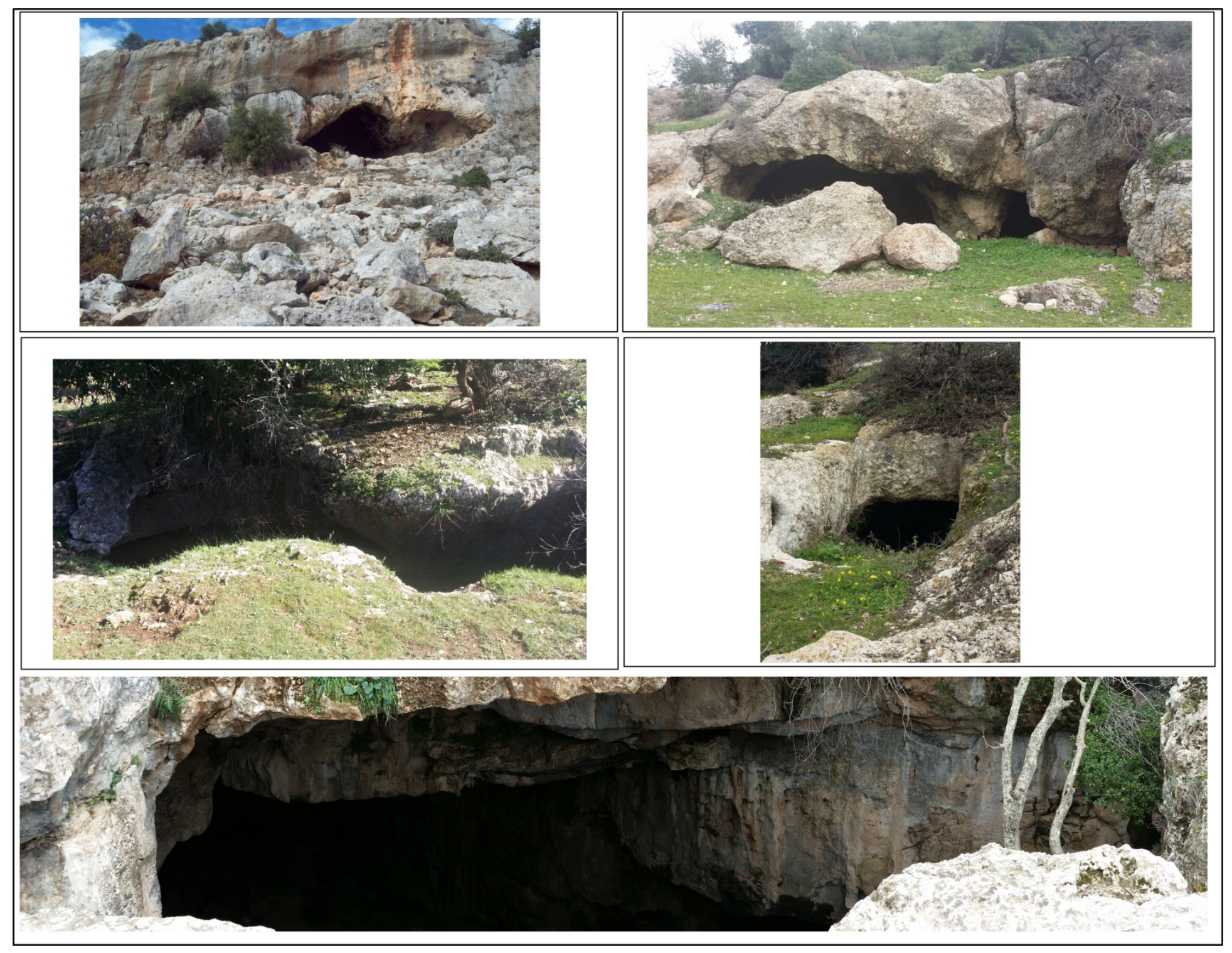

Figure 2-23: Caves occurring within the study area at different scales (photo source: Ibraheem Hamdan). 


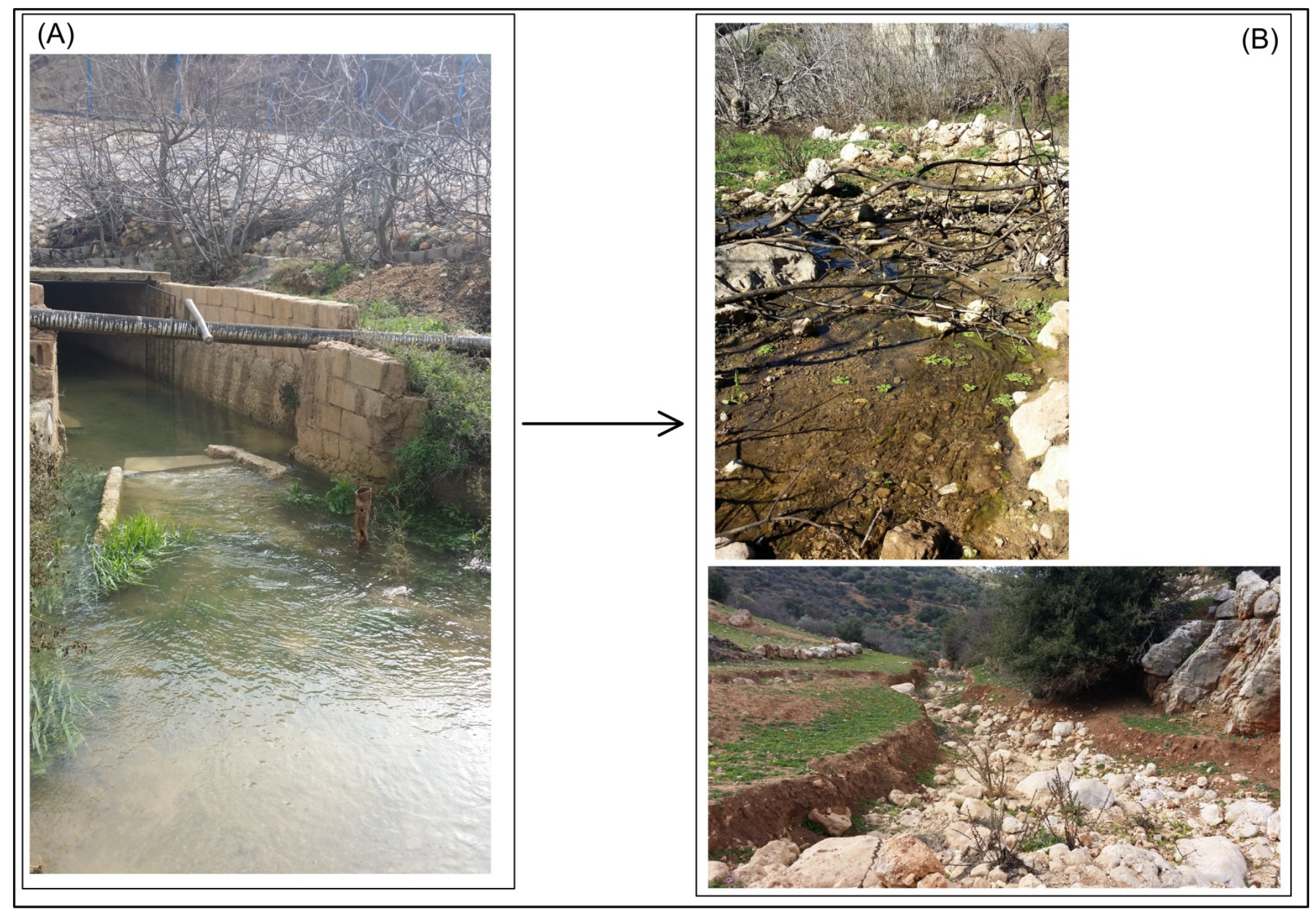

Figure 2-24: Dry valley near the Rasoun spring. (A): outflow from the Rasoun spring during winter, when there is no pumping. (B): the dry valley after the disappearance of water flow into the subsurface drainage system (photo source: Ibraheem Hamdan). 


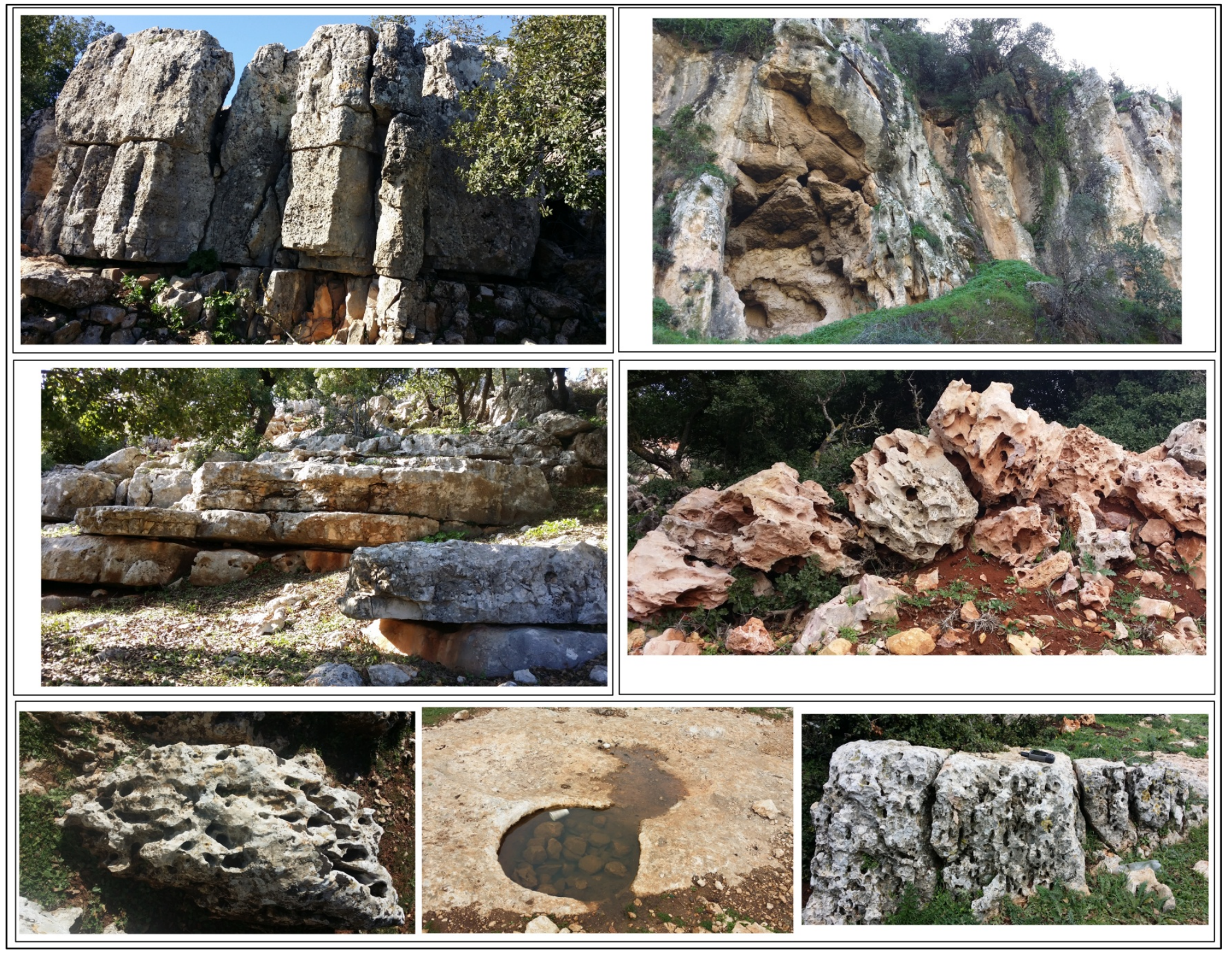

Figure 2-25: Fracturing and dissolution of limestone rock formations (photo source: Ibraheem Hamdan). 


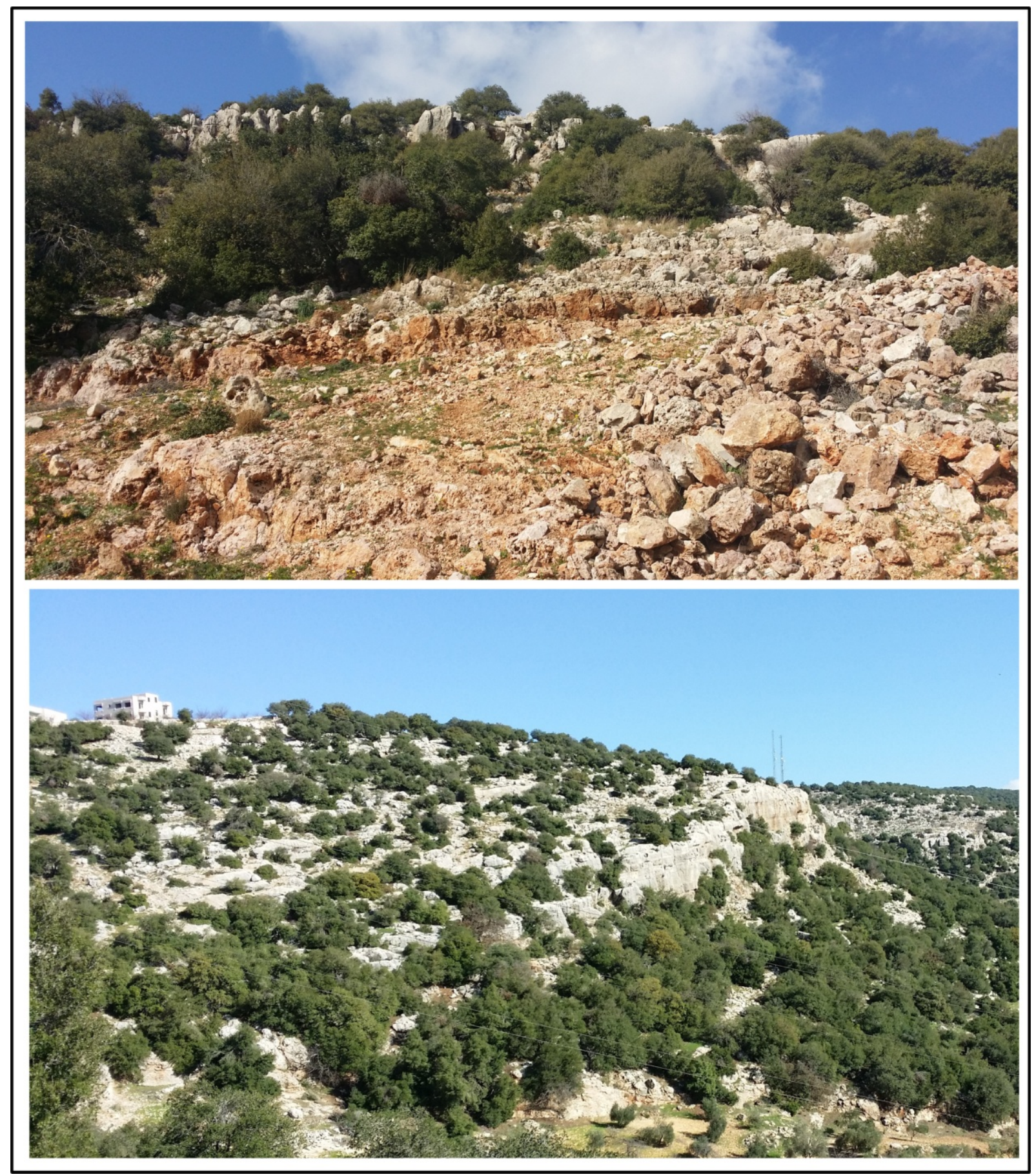

Figure 2-26: Large-scale karst pavement (photo source: Ibraheem Hamdan). 


\subsection{Hydrogeology}

\subsubsection{Hydrogeological aquifers within the study area}

Within the catchment area, water is potentially present in two aquifers, the A4 and A7/B2. According to Hobler et al. (2001), limestone is the predominant rock type in the entire lower Ajloun Group in the Yarmouk region (north of the study area), where it consists mainly of limestone, marly limestone and dolomitic limestone, and hence there is interconnections between the A1/6 aquifer and the A7/B2 aquifer. The catchment area is characterized by the extensive influence of widespread tectonic and karstic features on the aquifer system, with the Hummar (A4) aquifer believed to be hydraulically interconnected with the overlying Amman-Wadi as Sir (A7/B2) aquifer. Whereas there is very little water in the A7/B2 aquifer, despite its vast outcropping area, most springs in the study area discharge from the Hummar Formation (A4), which in contrast has a very limited outcropping area. As a result, A7/B2 represents a recharge area for A4, which is almost fully saturated while the A7/B2 aquifer carries water only seasonally.

\subsubsection{Estimation of hydraulic parameters for saturated zone}

Pumping test data obtained in karst landscapes are always questionable, depending almost entirely on whether the well is located in a karstic channel or not. No wells and their associated pumping test data are available within the study area, with most previous calculations carried out based on approximation or on large-scale estimation.

Hobler et al. (2001) assumed a hydraulic conductivity $K$ value of $2 * 10^{-5} \mathrm{~m} / \mathrm{s}$ for both the A4 and A7/B2 aquifers in the northern part of Jordan based on a statistical evaluation of available pumping test data, as well as an effective porosity $n_{e}$ value of $5 \%$ for the A7/B2 aquifer. ElNaser (1991) assumed a hydraulic conductivity value $K$ of $5^{*} 10^{-5} \mathrm{~m} / \mathrm{s}$ for the A7/B2 aquifer in the Amman-Zarqa Basin, together with an effective porosity range of between $1 \%$ and $3 \%$. MWI (2000) assumed a transmissivity value for the A4 aquifer in the Amman Zarqa basin ranging from $230-2800 \mathrm{~m}^{2} / \mathrm{d}$ and an effective porosity ranging between $1 \%$ and $10 \%$.

Due to the lack of specific information regarding both transmissivity and hydraulic conductivity within the study area, as well as the wide range of estimated values published in previous studies for a variety of different areas, the base flow recession method (Rorabaugh 1964, Sauter 1992) 
was here applied by using the hydrograph of Tanour spring discharge data (hourly discharge data) for the period between April 2014 and September 2015 (MWI-BGR 2015). This procedure enabled the acquisition of specific and precise estimated values of transmissivity and hydraulic conductivity for the catchment area under study. According to Sauter (1992), "the slope of the base flow recession curve for water released from bank storage after flood events plotted on a log-lin diagram (discharge-log $\left(\mathrm{m}^{3} / \mathrm{s}\right)$ ) is proportional to aquifer diffusivity".

According to Sauter (1992), transmissivity was calculated based on the following equation:

$$
T=\frac{\alpha 4 S L^{2}}{\pi^{2}}
$$

where $T\left[\mathrm{~m}^{2} / \mathrm{d}\right]$ is the transmissivity, $S[-]$ is the storage coefficient, $L[\mathrm{~m}]$ is the average distance between the spring and the groundwater divide in the case of the saturated zone, and for epikarst zone it represent the average flow length path towards the streams as a final recharge point (will be discussed later in Section 3.3), and $\alpha\left[\mathrm{d}^{-1}\right]$ is the base flow recession coefficient determined by Maillet (1905) as:

$$
\alpha=\frac{\log Q_{1}-\log Q_{2}}{0.4343\left(t_{2}-t_{1}\right)}
$$

where $Q_{1}, Q_{2}\left[\mathrm{~m}^{3} / \mathrm{s}\right]$ is the spring discharge at the beginning and end points of the recession curve (logarithmic scale), and $t_{2}-t_{1}[\mathrm{~d}]$ is the difference in time between the beginning and end points of the recession curve.

Within the catchment area, $L$ was assumed to equal $7000 \mathrm{~m}$, and $S$ equal to 0.02 . From Figure 2-27 it can be observed that the recession coefficient $\alpha$ ranged from $0.0023 \mathrm{~d}^{-1}$ to $0.0029 \mathrm{~d}^{-1}$ for aquifer matrix, up to $0.0611 \mathrm{~d}^{-1}$ for epikarst. Table 2-6 presents the calculated hydraulic parameters based on the above-described recession analysis. The estimation of the transmissivity and hydraulic conductivity values of the epikarst zone will be discussed later during the travel time physics-based method in Section 3.3). 


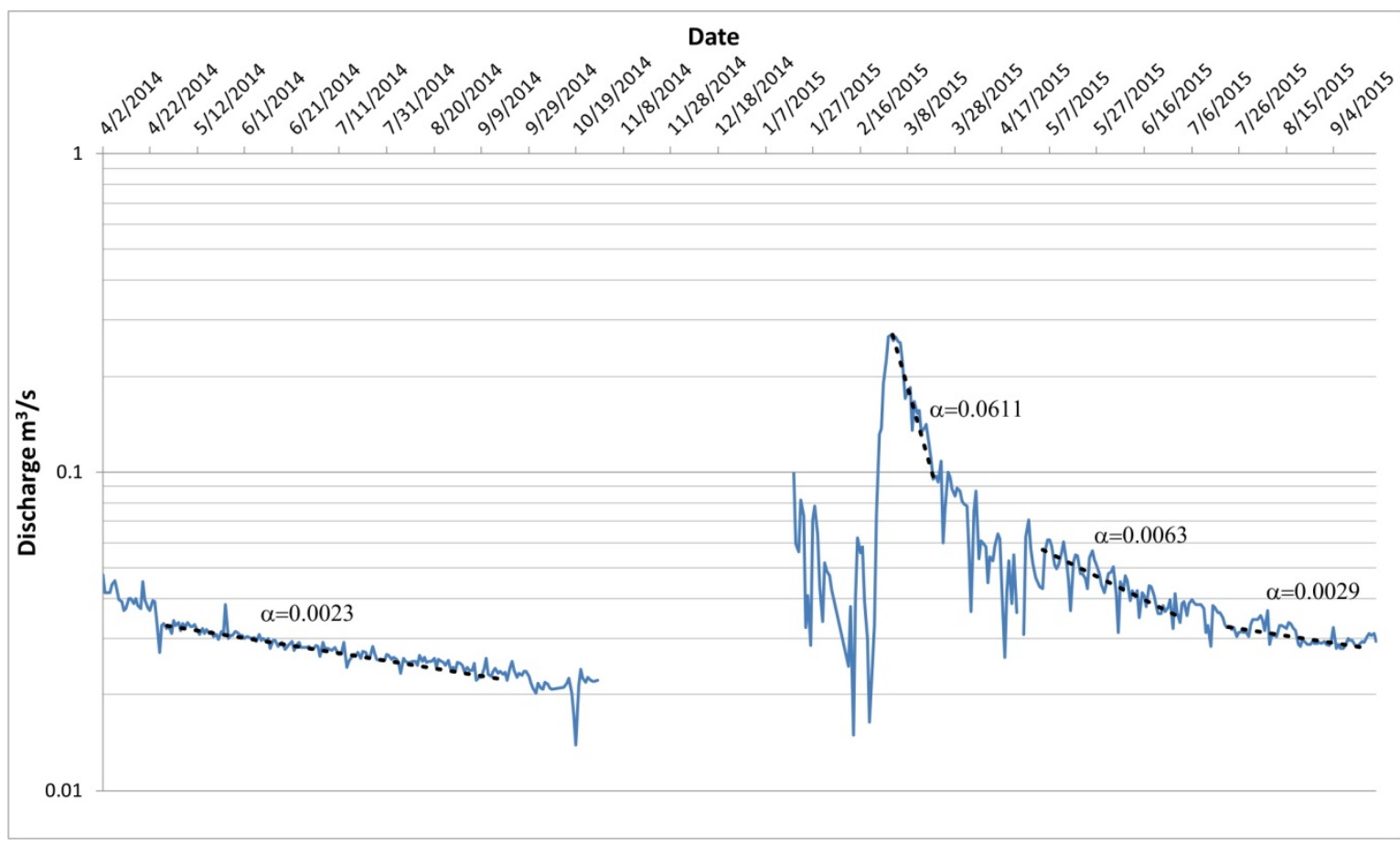

Figure 2-27: Base flow recession curve analysis for Tanour spring discharge data corrected using pumping data (based on the daily pumping rate).

Table 2-6: Hydraulic parameter evaluation based on the base flow recession curve analysis for Tanour spring.

\begin{tabular}{|c|c|c|c|c|c|c|}
\hline Flow type & $\begin{array}{c}\text { Recession } \\
\text { coefficient } \\
\qquad \alpha\left[\mathbf{d}^{-1}\right]\end{array}$ & $\begin{array}{c}\text { Storage } \\
\text { coefficient } \\
S[-]\end{array}$ & $\begin{array}{c}\text { Average } \\
\text { distance } \\
\text { to water } \\
\text { divide } L \\
\text { [m] }\end{array}$ & $\begin{array}{c}\text { Calculated } \\
\text { transmissivity } \\
T\left[\mathrm{~m}^{2} / \mathrm{d}\right]\end{array}$ & $\begin{array}{c}\text { Saturate } \\
\text { d } \\
\text { thicknes } \\
\text { s [m] }\end{array}$ & $\begin{array}{c}\text { Calculated } \\
\text { hydraulic } \\
\text { conductivity } \\
K[\mathbf{m} / \mathbf{d}]\end{array}$ \\
\hline $\begin{array}{l}\text { aquifer } \\
\text { matrix }\end{array}$ & 0.00230 & 0.02 & 7000 & $9.14 * 10^{2}$ & 90 & 10.15 \\
\hline $\begin{array}{l}\text { aquifer } \\
\text { matrix }\end{array}$ & 0.00289 & 0.02 & 7000 & $1.15^{*} 10^{3}$ & 90 & 12.76 \\
\hline mixed & 0.00634 & 0.02 & 7000 & $2.52 * 10^{3}$ & - & - \\
\hline epikarst & 0.06113 & \multicolumn{5}{|c|}{ will be discussed later in section 3.3.3; Table 3-9 } \\
\hline
\end{tabular}


As mentioned in Section 2.8, water within the catchment area is potentially present in two hydraulically interconnected aquifers (the A4 and A7/B2 aquifers). Considering this fact, $90 \mathrm{~m}$ was set as the saturated thickness value for the entire catchment area. Based on the calculated hydraulic conductivity $K$ (transmissivity divided by saturated thickness); average hydraulic conductivity value $\mathrm{K}$ for the aquifer matrix is $11.46 \mathrm{~m} / \mathrm{d}$.

\subsubsection{Recharge estimation}

Due to the limitations encountered regarding available data for the catchment area under study, the total rain water volume (MCM) and discharge water volume from springs (Tanour, Rasoun and Beida) were used in order to calculate the recharge percentage.

For this purpose, the following parameters were determined:

- Spring discharge: 2.734 MCM (total yearly average discharge for the Tanour, Rasoun and Beida springs for the time period from 1984 to 2013; water year: October to May).

- Catchment area: $36 \mathrm{~km}^{2}$

- Average rainfall amount within the catchment: $545 \mathrm{~mm} / \mathrm{yr}$ (water year) (based on longterm yearly average rainfall for the rainfall station AH0003; see Table 2-2).

- The catchment area (in square metres) was then multiplied by the average annual rainfall amount (in millimetres) in order to obtain the total volume of water falling on the catchment (in litres), here equal to 19.6 MCM. Based on the ratio of the spring discharge value (2.734 MCM) to the catchment rainfall volume (19.6 MCM), the calculated recharge percentage is $14 \%$. Aquifer storage can be considered negligible (constant) due to the use of long-term averages for spring discharge and rainfall in the calculations.

\subsection{Developing a 3-D geological model of the study area using ArcGIS and GOCAD software}

In order to obtain a clearer overview regarding the geological characteristics of the study area, a 3-D geological model was constructed of the surface-outcropping geological formations present within the study area using the ArcGIS and GOCAD software programs. For this purpose, the study area was expanded a little and two additional formations included (from older to younger): (1) The Na'ur formation (A1/2-Aquifer/Aquitard), consisting predominantly of a sequence of 
grey limestone and dolomitic limestone with intercalation of medium to thick bedded marl (Hobler et al. 1994). This formation represents the lower part of the Ajloun group (Upper Cretaceous). The lowest part of the formation consisting mainly of marls that form the confining layer separating the Na'ur limestone aquifer from the underlying Kurnub aquifer (Lower Cretaceous) (Margane et al. 2002); (2) The Fuheis Formation (A3-Aquitard), which is dominated by grey to greenish grey marl with intercalations of calcareous siltstone, and mostly thin-bedded grey to light brown limestone (Hobler et al. 1994).

A description of the other available geological formations used within the model can be found in Section 2.7 .

The model borders are located across two separate geological sheets (Jarash and Deri Abu Sa'id). Based on data published by Abdelhamid (1993; 1995) and Abu Qudaira (2005), Table 2-7 displays the formation thicknesses according to both the Jarash and Deir Abu Sa'id geological sheets, together with the average thicknesses used in the developed model.

Table 2-7: Geological formation thickness values used in the model.

\begin{tabular}{|c|c|c|c|}
\hline \multirow{2}{*}{ Formation } & \multicolumn{2}{|l|}{ Thickness (m) } & \multirow{2}{*}{$\begin{array}{l}\text { Average thickness } \\
\text { used in the model }\end{array}$} \\
\hline & Jarash $^{1}$ & Deir Abu Sa'id ${ }^{2}$ & \\
\hline Na'ur (A1/2) & $160-180$ & $50-100$ & $135 \mathrm{~m}$ \\
\hline Fuheis (A3) & $\sim 70$ & $55-80$ & 70 \\
\hline Hummar (A4) & $40-50$ & $45-60$ & 45 \\
\hline Shu'ayb (A5/6) & $55-70$ & $57-80$ & 65 \\
\hline Wadi as Sir (A7) & $\begin{array}{l}70 \mathrm{~m} \text { in the southeastern part to } \\
220 \mathrm{~m} \text { in the northwestern part } \\
\text { of the study area. }\end{array}$ & $57-80$ & $\begin{array}{l}\text { Interpolation via GIS } \\
\text { (as described below) }\end{array}$ \\
\hline $\begin{array}{l}\text { Wadi Umm Ghudran } \\
\text { (B1) }\end{array}$ & $30-35$ & $25-40$ & 35 \\
\hline $\begin{array}{l}\text { Amman Silicified } \\
\text { Limestone (ASL) / } \\
\text { Al Hisa Phosphorite } \\
\text { (AHP) (B2) }\end{array}$ & $60-70$ & $\begin{array}{l}\sim 70 \\
\end{array}$ & 65 \\
\hline \multicolumn{4}{|c|}{$\begin{array}{l}\text { 1: Abdelhamid (1993; 1995). } \\
\text { : Abu Qudaira (2005). } \\
\text { : Available well lithologies (MWI 2014c) in the area were used in order to estimate A1/2 } \\
\text { thickness due to the large variation between the descriptions provided in the Jarash and Deir } \\
\text { Abu Sa'id geological sheets. }\end{array}$} \\
\hline
\end{tabular}


Considering the large variation in Wadi as Sir (A7) thickness found within the model area, the "spline with barrier" interpolation method was employed in ArcGIS in order to obtain an optimal thickness value for the A7 formation (Figure 2-28), based on (1) thicknesses derived from available well lithologies (MWI 2014c) and (2) the A7 thickness value mentioned in both of the geological sheet maps.

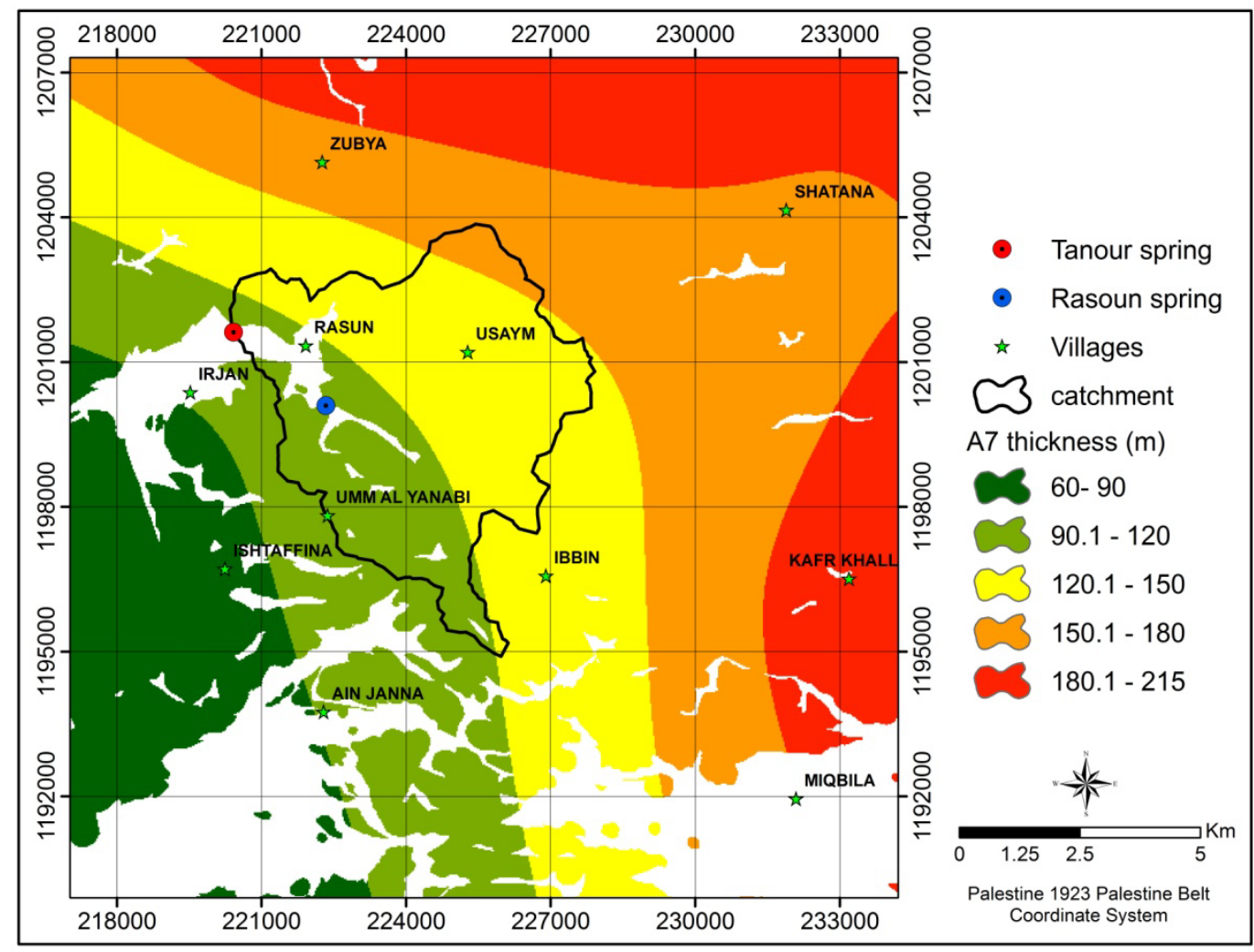

Figure 2-28: Wadi as Sir (A7) geological formation thickness obtained via the "spline with barrier" ArcGIS interpolation method.

After data preparation and processing, base elevations were calculated separately for each geological layer in ArcGIS. Resulted shape files then converted into text file format (*.txt) in order to process them in the GOCAD software program. Finally, the data point set prepared in ArcGIS was imported in GOCAD in XYZ format and surfaces created.

During model construction, a number of limitations were encountered related to data availability, such as dip angles being unavailable in the original geological maps. Furthermore, the thickness of A7 was estimated based on interpolation in ArcGIS (according to available information, as 
mentioned above) and thus values for some areas lie within a certain error limit. Considering these inadequacies, the model remains open for further development, especially that related to dip angle, dip direction and surface enhancement.

Figure 2-29 presents a 3-D overview of the modelled area, while Figure 2-30 shows the bases of the geological formation surfaces (m a.s.l.) for A1/2, A3, A4, A5/6 and A7 based on the obtained GOCAD interpolation results. It should be noted that the bases of the B1 and B2 geological formations are not included in Figure 2-30 as these two formations are available in the northeast of the study area as dispersed spots. 



Figure 2-29: 3-D model view of the geological formations located within the study area: (a) with the geological sheet at the top, and (b) bases of the A1/2, A3, A4, A5/6 and A7 geological formations. 

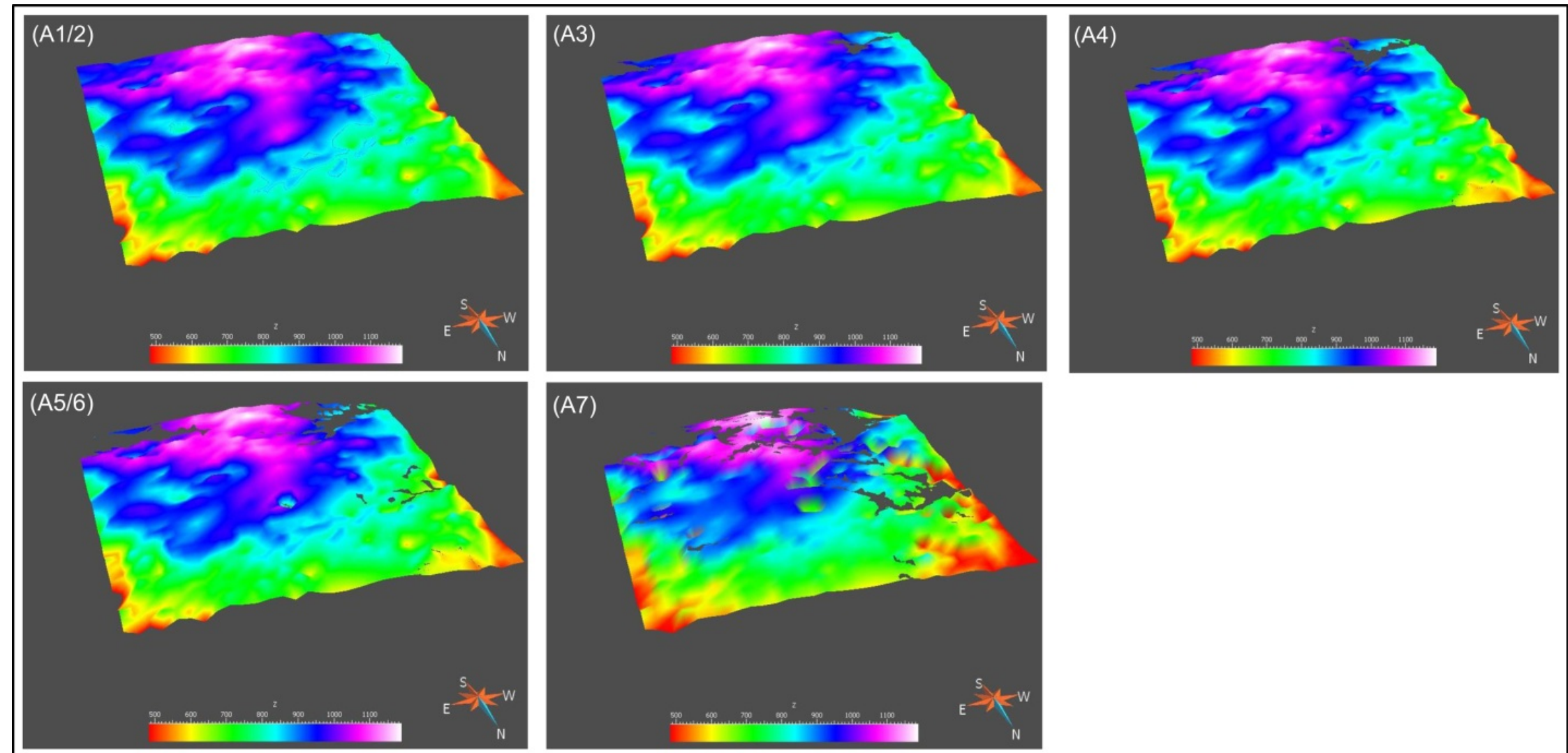

Figure 2-30: Bases of the A1/2, A3, A4, A5/6 and A7 geological formation surfaces (m a.s.l.) based on GOCAD interpolation. 


\subsection{References}

Abdelhamid G. (1993) Geological map of Jarash [map]. Ministry of Energy and Mineral Resources - Natural Resources Authority (NRA) (Geology directorate). National mapping project. Map sheet No. (3154-I); 1 sheet: 1:50.000. Amman, Jordan.

Abdelhamid G. (1995) The Geology of Jarash Area - Map sheet No. (3154-I), Bulletin 30. Ministry of Energy and Mineral Resources - Natural Resources Authority (NRA) (Geology directorate). Amman, Jordan.

Abi Rizk J., Margane A. (2011) Mapping of surface karst features in the Jeita spring catchment. Republic of Lebanon Council for Development and Reconstruction (CDR) and Federal Institute for Geosciences and Natural Resources (BGR). Special report No.7. Project No.: 2008.2162.9.

Abu Qudaira M. (2005) Geological map of Dayr Abu Sa'id [map]. Ministry of Energy and Mineral Resources - Natural Resources Authority (NRA) (Geology Directorate). National mapping project. Map sheet No. (3154-IV); 1 sheet: 1:50.000. Amman, Jordan.

El-Naser, H. (1991) Groundwater resources of the deep aquifer systems in NW - Jordan: hydrogeological and hydrochemical quasi 3-dimensional Modelling. Hydrogeologie und Umwelt. Heft 3. Wuerzburg, Germany.

Hobler M., Margane A., Saffarini I., Almomani M., Hammoudeh A., Ouran S., Rayyan M., Hijazi H., Kalbouneh A., Subah A. (1994) Groundwater resources of northern Jordan. Vol.3 Structural features of the main hydrogeological units in northern Jordan. Federal Institute for Geosciences and Natural Resources (BGR) and Ministry of Water and Irrigation (MWI). Amman, Jordan.

Hobler M., Margane A., Almomani M., Subah A. (2001) Groundwater resources of northern Jordan. Vol.4 Contributions to the hydrogeology of northern Jordan. Federal Institute for Geosciences and Natural Resources (BGR) and Ministry of Water and Irrigation (MWI). Amman, Jordan.

JMD (Jordan Meteorological Department) (2014) Daily pan-A evaporation, minimum and maximum temperature data for the time period between 1980-2013 (soft copy). Amman, Jordan (unpublished). 
Maillet E. (1905) Essais d'Hydraulique souterraine et fluviale, Hermann, Paris (cited in Ford and Williams, 2007).

Margane A., Qunqar E., Taha S., Almomani M., Subah A., Khalifa N., Rayyan M., Naber L., Jaber A., Zuhdi Z., Atrash M., Hijazi H. (2002) National water master plan. Volume IVGroundwater resources. Technical report No. 3. Federal Institute for Geosciences and Natural Resources (BGR) and Ministry of Water and Irrigation (MWI). Amman, Jordan.

Masri M. (1963) Report on the geology of the Amman-Zarqa area. Central water authority 174 (unpublished report). Amman, Jordan (cited in Abdelhamid, 1995).

Ministry of Agriculture (1994) National soil map and land use project- the soil of Jordan. Level 2: semi detailed studies. Volume 2: main report. Hunting technical services in association with soil survey and land research centre. Amman, Jordan.

MWI (Ministry of Water and Irrigation) (2000) Online hydrogeology of the Amman-Zarqa basin. Water resources policy support. Groundwater management component. Amman, Jordan.

MWI (Ministry of Water and Irrigation) (2014a) Historical daily rainfall data for the time period between 1961/1962-2013/2014 (water years) (soft copy). Water information system, national master plan directorate. Amman, Jordan (unpublished).

MWI (Ministry of Water and Irrigation) (2014b) Daily pan-A evaporation, minimum and maximum temperature data for the time period between 1969-1979 (soft copy). Water information system, national master plan directorate. Amman, Jordan (unpublished).

MWI (Ministry of Water and Irrigation) (2014c) Wells lithology description (soft copy). Water information system, national master plan directorate. Amman, Jordan (unpublished).

MWI (Ministry of Water and Irrigation) (2015a) Monthly averages springs discharge for Tanour and Rasoun springs for the time period between 1968 and 2014 (soft copy). Water information system, national master plan directorate. Amman, Jordan (unpublished). 
MWI (Ministry of Water and Irrigation) (2015b) Monthly production values for Tanour and Rasoun springs for the time period between 1996 and 2014 (soft copy). Water information system, national master plan directorate. Amman, Jordan (unpublished).

MWI (Ministry of Water and Irrigation) - BGR (Federal Institute for Geosciences and Natural Resources). (2015) Automated online regular and continuous data measurement for spring discharge values for the winter season 2014/2015 (soft copy). Jordan (unpublished).

Rorabaugh M.I. (1964) Estimating changes in bank storage and ground-water contribution to streamflow. International association of scientific hydrology. Publication 63, p. 432441.

Sauter M. (1992) Quantification and forecasting of regional groundwater flow and transport in a karstic aquifer (Gallusquelle, Malm, SW. Germany). Tübinger Geowissenschaftliche Arbeiten (TGA), PhD dissertation. Germany.

Stokes T., Griffiths P., Ramsey C. (2010) Karst geomorphology, hydrology, and management (Chapter 11). The British Columbia groundwater association, Accessed: June 2015. Available from: https://www.for.gov.bc.ca/hfd/pubs/docs/lmh/lmh66/lmh66_ch11.pdf.

USGS Earth Explorer (2014a) ASTER Digital Elevation Model (DEM) 30 m resolution. Accessed: June 2014. Available from: http://earthexplorer.usgs.gov.

USGS Earth Explorer (2014b) Landsat 8 satellite image, Landsat scene identifier No. LC81740382014124LGN00. Accessed: June 2014. Available from: http://earthexplorer.usgs.gov. 


\section{Chapter three: Groundwater vulnerability}

assessment of karst aquifers using a travel time

physics-based method, and COP and EPIK

intrinsic vulnerability assessment methods

Related articles to this chapter:

> Hamdan I, Margane A, Ptak T, Wiegand B, Sauter M. Groundwater vulnerability assessment for the karst aquifer of Tanour and Rasoun springs catchment area (NWJordan) using COP and EPIK intrinsic methods. Under review (March 2016). Environmental Earth Sciences Journal.

> Hamdan I, Ptak T, Sauter M, Wiegand B. Travel time physics-based groundwater vulnerability assessment for non-point pollution sources in karst aquifers - An example from the Tanour and Rasoun spring catchment, NW-Jordan. Under review (June 2016). Journal of Hydrology. 


\subsection{Overview on groundwater vulnerability assessment}

\subsubsection{Background and definition}

Foster and Hirata (1988) defined "aquifer pollution vulnerability" as the "intrinsic characteristics which determine the sensitivity of various parts of an aquifer to being adversely affected by an imposed contaminant load". The groundwater vulnerability assessment concept depends mainly on the fact that the physical environment itself provides natural attenuation, protection and purification capability to groundwater against pollutants during its passage through the unsaturated zone, especially against the contaminants that entering the subsurface environment due to the human impacts (Vrba and Zaporozec 1994, Tripet et al. 2000, Goldscheider 2003, Sililo et al. 2001).

During the COST Action 620 (2003), two types of vulnerability assessments and mapping in karstic environments have been distinguished by Goldscheider (2003). The first one is the intrinsic vulnerability, which is taking into consideration the natural characteristics of the aquifer itself (geological, hydrological and hydrogeological characteristics) without taking into account the nature of the contaminant itself. The second type is the specific vulnerability, which is taking into consideration the intrinsic vulnerability in combination with the properties of the contaminant itself and the contamination scenarios.

According to Daly et al. (2002), three basic aspects have to be considered in order to quantify the intrinsic vulnerability assessment:

1. Advective transport time from the origin to the target.

2. Final contaminants quantity that can reach the target.

3. Natural attenuation of pollutants concentration from the origin to the target, e.g. by dispersion, dilution, etc.

Groundwater vulnerability assessment maps can be considered an important and valuable tool for protecting the groundwater resources from pollution, where it allows for better understanding of the risks and vulnerabilities, allowing the decision-makers to decide where resources are needed for protection. In all groundwater vulnerability assessment methods, the vulnerability of an aquifer is classified according to the water travel time from the land surface to the aquifer (percolation time within the unsaturated zone) (Margane 2003). In addition to that, Godscheider 
(2003) determined the groundwater vulnerability assessment concept based on a model called "origin-pathway-target model for environmental management" (Figure 3-1), where the origin representing the location of the potential contaminant, pathway is the flow path from the (origin) towards the water as the final target.

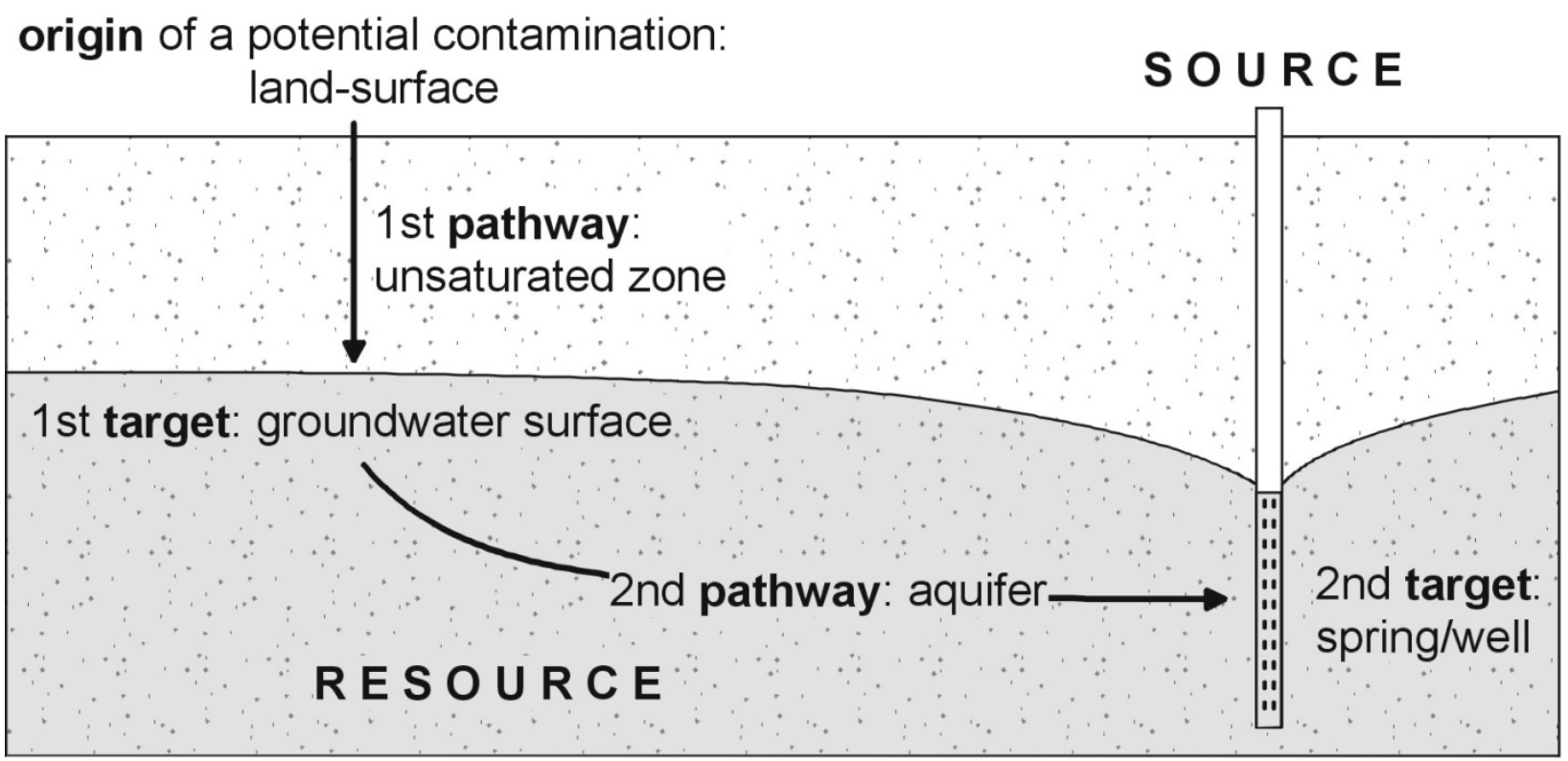

Figure 3-1: Origin-pathway-target model for environmental management (Goldscheider 2003).

On the other hand, Popescu et al. (2008) determined two types of contamination that impact the target: (1) direct (vertical) impact of contamination and (2) lateral (horizontal) impact of contamination based on the surface hydrological conditions (e.g. slope gradient). In order to apply a vulnerability assessment, Brouyere et al. (2001) showed that there are three practical questions that must be answered based on three factors describing the pollution event by a "conservative contaminants" (Figure 3-2) as follow:

1. "When should the pollution start"?; the contaminant transfer time.

2. "For how long"?; the contamination duration.

3. "To which level"?; the level of concentration reached by the contaminant. 


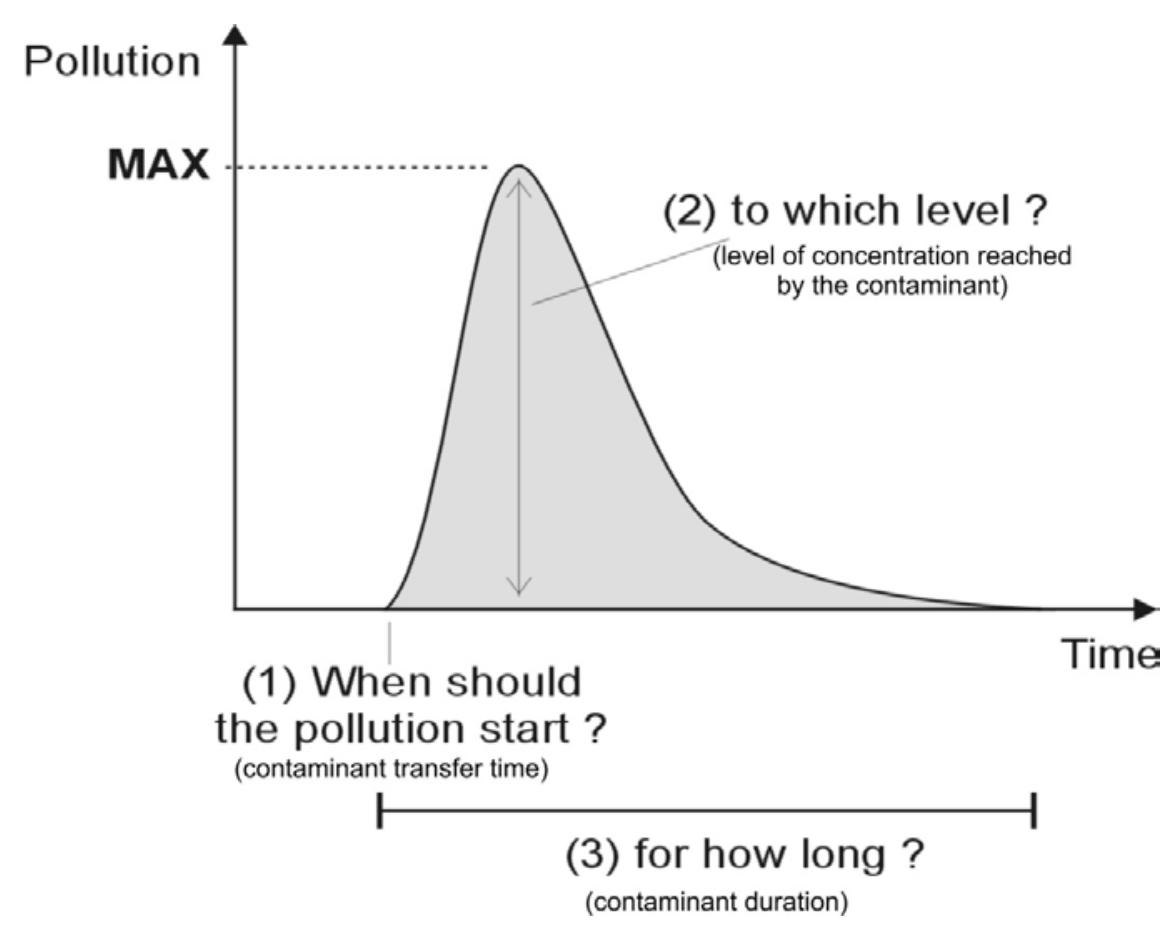

Figure 3-2: Brouyere schematic diagram for the three questions and the related factors, that descriping any pollution event by conservative contaminants.(modified after Brouyere et al. 2001).

Over time, many different vulnerability assessment methods has been developed (DRASTIC (Aller et al. 1987); GOD (Foster 1987); PI (Goldscheider et al. 2000); EPIK (Doerfliger et al. 1999); SINTACS (Civita and De Maio 1997); COP (Vias et al. 2002, 2006); GLA (Hoelting et al. 1995); AVI (Van Stempvoort et al. 1993); VULK (Jeannin et al. 2001); PaPRIKa (Kavouri et al. 2011), etc. Not all vulnerability assessment methods are applicable to karst aquifers; some of these methods do not take into consideration the karst features and the infiltration and recharge regime in the karst aquifers. Table 3-1 represents the most common intrinsic vulnerability assessment methods that have been developed, and the parameters used in each method. 
Table 3-1: Intrinsic vulnerability assessment methods and the parameters affecting these methods (Doummar 2012).

\begin{tabular}{|l|l|}
\hline \multicolumn{1}{|c|}{$\begin{array}{c}\text { Vulnerability } \\
\text { assessment method }\end{array}$} & \multicolumn{1}{|c|}{ Parameters affecting vulnerability } \\
\hline DRASTIC & $\begin{array}{l}\text { Depth to water (D), net Recharge (R), Aquifer media (A), Soil } \\
\text { media (S), Topography (T), Impact of vadose zone (I), hydraulic } \\
\text { Conductivity (C). }\end{array}$ \\
\hline SINTACS & $\begin{array}{l}\text { Groundwater table depth from surface (S), actual infiltration (I), } \\
\text { self-depuration effect unsaturated zone (N), overburden type (T), } \\
\text { hydrogeological characteristics of the aquifer (A), hydraulic } \\
\text { conductivity (C), topographical surface slope (S). } \\
*: \text { the letters come from the Italian words. }\end{array}$ \\
\hline GOD & $\begin{array}{l}\text { Groundwater occurrence (G), Overall lithology (O), Depth to } \\
\text { Groundwater table (D) }\end{array}$ \\
\hline COP & $\begin{array}{l}\text { The Concentration of flow (C), Overlying layers (O), Precipitation } \\
\text { (quantity and temporal distribution) (P). }\end{array}$ \\
\hline PI & $\begin{array}{l}\text { Protective function of the layers between the ground surface and } \\
\text { groundwater (P), Infiltration conditions (I). }\end{array}$ \\
\hline EPIK & $\begin{array}{l}\text { Epikarst (E), Protective cover (P), Infiltration Condition (I), Karst } \\
\text { Network (K) }\end{array}$ \\
\hline
\end{tabular}

\subsubsection{The "European approach" for groundwater vulnerability assessment}

This approach was developed during the COST Action 620 (2003) as a conceptual framework for mapping the intrinsic vulnerability assessment of karstic aquifers. The European approach is based on four factors presented in a conceptual model (Figure 3-3): (1) Overlying layer (O factor), (2) Concentration of flow (C factor), (3) Precipitation regime (P) and (4) Karst network development (K) (Goldscheider and Popescu 2003). This four factors represents the base for different groundwater vulnerability assessment methods such as the PI method (Goldscheider et al. 2000), and the COP method (Vias et al. 2002), and it can be used also for developing a new further methods.

According to Goldscheider and Popescu (2003), for the resource vulnerability, the C, O and P factors should be considered, where the saturated zone is the target, and only the vertical flow in the aquifer is considered. By contrast, for source vulnerability where the spring or well is the target, both of the vertical and the horizontal flow in the aquifer have to be considered, and all the $\mathrm{O}, \mathrm{C}, \mathrm{P}$ and $\mathrm{K}$ factors should be taken into consideration. 


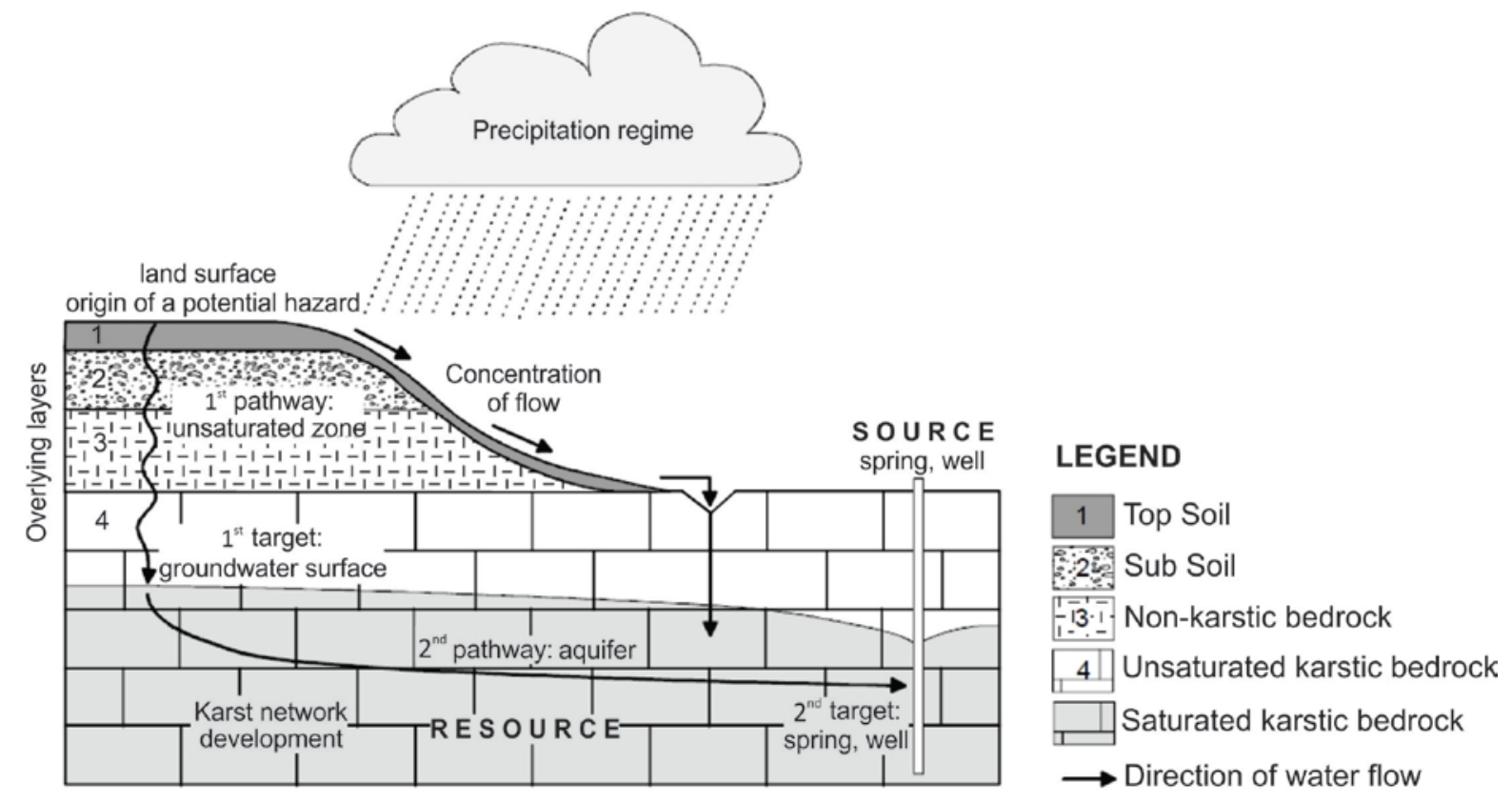

Figure 3-3: The European approach conceptual model (Goldscheider 2002).

\section{- The $\mathbf{O}$ factor}

According to Goldscheider and Popescu (2003) and Daly et al. (2002), the overlying layers represent the whole layers that are located between the land surface and water table (groundwater surfaces), and it consist of up to four types of layers: (1) topsoil, (2) subsoil, (3) non-karstic bedrock and non-karstic rocks, and (4) unsaturated karstic bedrock (the vadose zone) including the epikarst zone.

\section{- $\quad$ The $C$ factor}

Based on Goldscheider and Popescu (2003), "the C factor represents the degree to which precipitation is concentrated towards places where fast infiltration can occur" like sinkholes and large conduits. Daly et al. (2002) reported that the C factor represents the flow concentration based on the availability of different karst features that concentrated the flow, in addition to the presence of the parameters that control the runoff such as the slope, vegetation cover, etc. 


\section{- The $\mathbf{P}$ factor}

The precipitation duration and intensity, quantity, and frequency playing an important role on the groundwater vulnerability assessment of the karst aquifers. According to Goldscheider and Popescu (2003), intensive precipitation events lead to generate a surface runoff, and then wash out all the surface and subsurface pollutants which may reach the groundwater at the end via dry valley or swallow hole.

\section{- The $\mathrm{K}$ factor}

The $\mathrm{K}$ factor represents the degree of karst network development in the aquifer. It is considered an important factor for assessing the intrinsic groundwater vulnerability assessment for karstic aquifers. Figure 3-4 shows the relation between the developing of the karst network and the increase in the flow concentration degree within the karst aquifer which has been suggested by Goldscheider and Popescu (2003).

\begin{tabular}{|c|c|c|}
\hline network & $\begin{array}{c}\text { intergranular } \\
\text { porosity }\end{array}$ & $\begin{array}{c}\text { type of } \\
\text { carbonate aquifer }\end{array}$ \\
\hline absent & no & (no aquifer) \\
\hline absent & low-high & intergranular aquifer \\
\hline fractures & high & fractured aquifer \\
& low & \\
no & high & \\
enlarged & low & \\
fractures & no & \\
slow active & high & \\
conduit & low & \\
network & no & \\
\hline fast active & high & \\
conduit & low & \\
network & no & \\
\hline \multicolumn{2}{|c|}{} \\
\hline
\end{tabular}

Figure 3-4: Relation between the karst network (type and availability) in the carbonate aquifers and the flow concentration (Goldscheider and Popescu 2003). 


\subsection{Applying the COP and EPIK intrinsic vulnerability assessment methods for the karstic aquifer of Tanour and Rasoun spring}

\subsubsection{General overview on COP and EPIK vulnerability assessment methods}

The COP groundwater vulnerability assessment method was developed during the COST Action 620 (2003) for the assessment of intrinsic vulnerability of karstic aquifers, and it was tested by developers in southern Spain (Vias et al. 2002; 2006). The COP method is based on the European Approach for intrinsic vulnerability mapping and is based on three factors proposed in the following formula (Vias et al. 2006):

$$
\operatorname{COP}_{\text {index }}=C_{\text {score }} \cdot O_{\text {score }} \cdot P_{\text {score }}
$$

where:

- C: flow Concentration.

- O: Overlying layers above the water table.

- P: Precipitation over the aquifer.

The whole COP process is summarised in Figure 3-5.

Vias et al. (2003) determined two necessary conditions to assess the intrinsic vulnerability by the COP: (1) contaminants depends mainly on the water as a transporter medium to move through the aquifer, and (2) "the contaminant infiltrates from the surface by means of rainfall".

On the other hand, the EPIK method (Doerfliger et al. 1999) is one of the intrinsic vulnerability assessment methods that has been developed especially for karst areas based on four parameters: epikarst (E), protective cover (P), Infiltration (I), and karst network development (k).

Within this study, two different intrinsic vulnerability assessment methods were chosen for use in the study area based on the data availability of the area: COP and EPIK vulnerability assessment methods. ArcGIS software was used to generate all the required thematic maps and to conduct all the raster calculations in order to get the final COP and EPIK groundwater vulnerability map. 


\subsubsection{Data requirement for COP and EPIC vulnerability assessment methods}

In order to apply the COP and EPIK vulnerability assessment methods, different parameters and data sources were collected in different formats. Table 3-2 shows the data and information required for the COP and EPIK vulnerability assessment methods.

Table 3-2: Data available and required for applying COP and EPIK vulnerability assessment methods.

\begin{tabular}{|l|l|}
\hline \multicolumn{1}{|c|}{ Factor } & \multicolumn{1}{c|}{ Data needed and its source } \\
\hline $\begin{array}{l}\text { Karst features } \\
\text { (epikarst) and network } \\
\text { development }\end{array}$ & $\begin{array}{l}\text { Field work within the study area to obtain: } \\
\text { A detailed description of the karst features within the } \\
\text { study area. }\end{array}$ \\
$\begin{array}{l}\text { Waypoints for the karst feature locations and their } \\
\text { extensions using GPS. } \\
\text { Photos from the field for the karst features. }\end{array}$ \\
\hline Slope and vegetation & $\begin{array}{l}\text { - Classified land-cover map for the area. Landsat 8 image } \\
\text { (USGS 2014a) has been used in order to generate this layer by } \\
\text { using ArcGIS software. } \\
\text { - Digital Elevation Model 30m resolution type ASTER (USGS } \\
\text { 2014b). }\end{array}$ \\
\hline Protective cover (Soil) & $\begin{array}{l}\text { - Soil units map with texture description and estimated } \\
\text { thickness of each unit (Ministry of Agriculture 1994). }\end{array}$ \\
\hline Lithology & $\begin{array}{l}\text { - Outcropping geological formations for the area as a shape file } \\
\text { scale 1:50,000 including a lithological description for each } \\
\text { formation (Abdelhamid 1993; 1995). } \\
\text { - Thickness of the unsaturated zone (calculated) }\end{array}$ \\
\hline $\begin{array}{l}\text { Precipitation quantity } \\
\text { and temporal } \\
\text { distribution }\end{array}$ & $\begin{array}{l}\text { - Long term daily rainfall data for a meteorological station } \\
\text { within the study area (MWI 2013). }\end{array}$ \\
\hline
\end{tabular}

These data were processed and analysed using ArcGIS software (ESRI @ , 1999-2014) with a grid size of $30 * 30$ metres. 


\subsubsection{Methodology}

\subsubsection{COP method}

\section{- The $\mathrm{C}$ factor (flow concentration)}

The $\mathrm{C}$ factor is taken as a corrector coefficient of the $\mathrm{O}$ factor. The $\mathrm{C}$ factor is calculated based on two scenarios:

1. 'Swallow hole recharge area' scenario. This scenario can be obtained as follows:

$$
C_{\text {score }}=d h . d s . s \mathrm{~V}
$$

where:

- dh: distance to swallow hole (Figure 3-5, Table VII).

- ds: distance to sinking stream (Figure 3-5, Table VIII).

- sv: slope and vegetation (Figure 3-5, Table IX).

2. 'Rest of the area' scenario: This scenario describes the areas where the recharge occur as "autogenic recharge" (not via a swallow holes) (Vias et al. 2006). This scenario based mainly on two parameters:

- Surface features (sf) (Figure 3-5, Table X).

- Slope and Vegetation (sv) (Figure 3-5, Table XI)

The $\mathrm{C}_{\text {SCORE }}$ for this scenario can be calculated as follows:

$$
C_{\text {score }}=s f . s \mathrm{~V}
$$

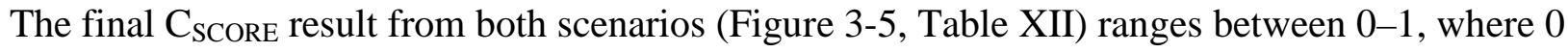
represents the highest reduction of protection and 1 represents the lowest reduction of protection.

\section{- The $\mathbf{O}$ factor (overlying layer)}

According to Vias et al. (2003), the overlying factor represents the protection of the unsaturated zone against pollutants, where it reflect the ability of the unsaturated zone to filter or to attenuate the contaminants concentration, and then reduce its effects on groundwater. Within the COP method, the $\mathrm{O}$ factor is divided into two sub-factors: (1) the soil texture and thickness $\left(\mathrm{O}_{\mathrm{s}}\right)($ sand, 
silt, clay, loam), and (2) the lithology of the unsaturated zone $\left(\mathrm{O}_{\mathrm{L}}\right)$, which is characterised by three parameters: lithology and fracturation (ly), unsaturated thickness of each layer (m), and confining conditions (cn) (Figure 3-5, Tables I-V).

The final $\mathrm{O}_{\text {SCORE }}$ is calculated as follows:

$$
O_{\text {score }}=O_{S}+O_{L}
$$

According to Vias et al. (2006), the lowest values of the $O$ factor represents the areas where the soil cover over the carbonate rocks either absent or not well developed. On the other hand, the high $\mathrm{O}_{\text {SCORE }}$ values (moderate and high protection values) representing the areas with high degree of protection due to the presence of a protective cover such as thick soil cover or lowpermeability materials (Figure 3-5, Table VI).

\section{- The P factor (precipitation)}

Based on Daly et al. (2002), this factor includes the quantity and the temporal distribution of the precipitation together, where both of them can have a huge effect on the final infiltration rate and quantity. The $\mathrm{P}_{\mathrm{SCORE}}$ is based on two parameters:

1. Quantity of the precipitation $\left(\mathrm{P}_{\mathrm{Q}}\right)$ (average rainfall for wet years) (Figure 3-5, Table XIII). In this parameter, only the mean average rainfall of the wet years is considered (wet year $\geq$ $(0.15 \cdot \bar{X})+\bar{X})$.

2. Temporal distribution of the precipitation $\left(\mathrm{P}_{\mathrm{I}}\right.$ ) (Figure 3-5, Table XIV), which is calculated as: Precipitation (mm/yr) / Number of rainy days.

The final $\mathrm{P}_{\mathrm{SCORE}}$ obtained is as follows:

$$
P_{\text {score }}=P_{Q}+P_{I}
$$

The final $\mathrm{P}_{\mathrm{SCORE}}$ result (Figure 3-5, Table XV) ranges from 0.4-1, where 0.4 represents the highest reduction of protection compared with 1 , which represents the lowest reduction of protection. 


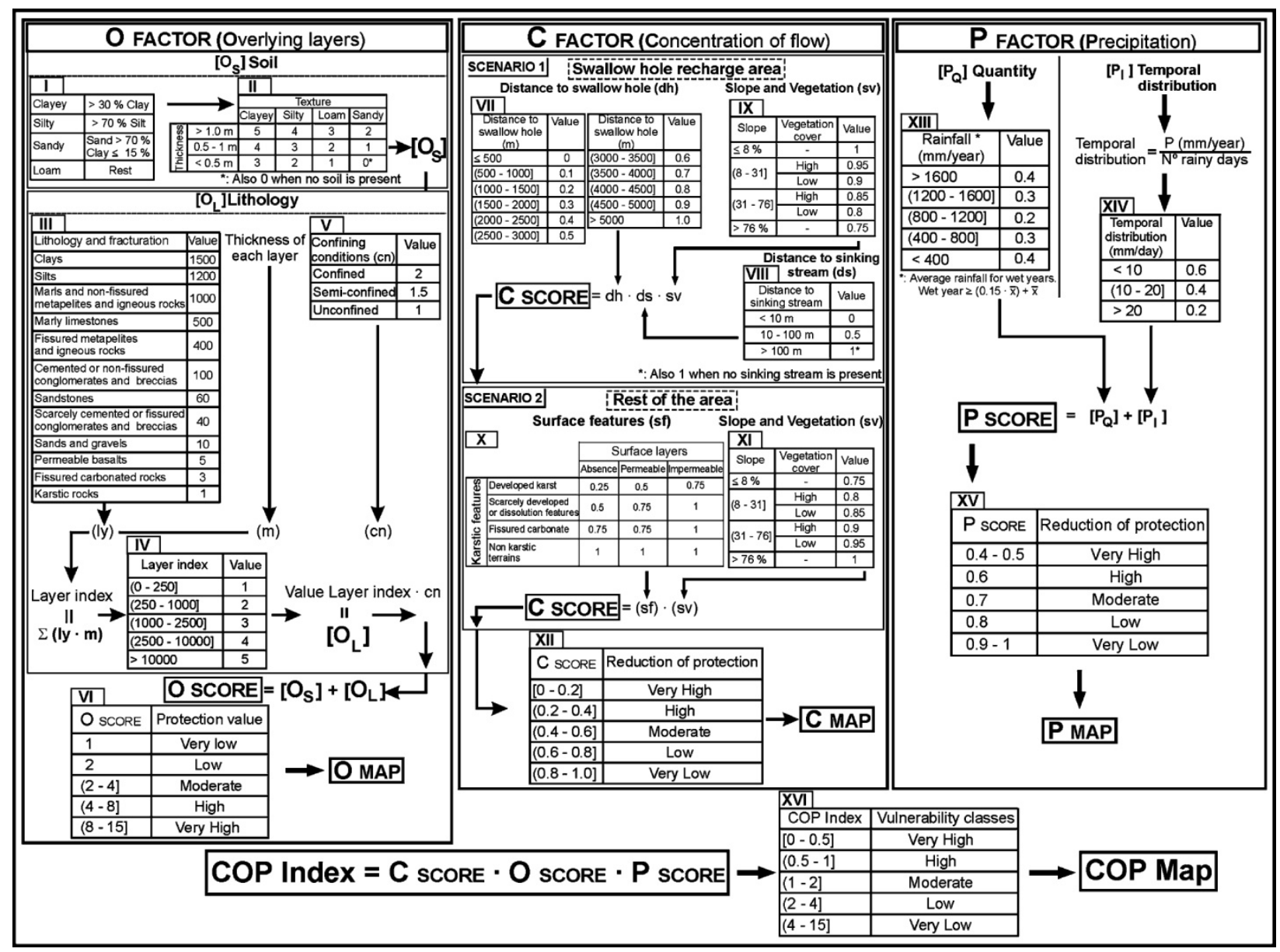

Figure 3-5: COP method diagram and the numeric evaluation of Tables I-XVI (Vias et al. 2006). 


\subsubsection{2. $\quad$ EPIK method}

EPIK is an acronym for four parameters; Epikarst (E), Protective cover (P), Infiltration condition (I) and Karst network development (K) (Figure 3-6).

1. Epikarst (E): The epikarst zone is defined, by Klimchouk (1997), as "the uppermost zone of outcropping karstified rocks, in which permeability due to fissuring and diffuse karstification is substantially higher and more uniformly distributed than in the rock below". The epikarst zone has been divided into three classes based on the karst morphological features: E1, E2 and E3 (see Figure 3-6).

2. Protective cover (P): According to Doerfliger and Zwahlen (1998), the protective cover includes the soil and the other geological formations, that overlie the karstic aquifer. The protective cover has been divided into four categories: P1, P2, P3 and P4 (see Figure 3-6).

3. Infiltration conditions (I): This factor considers the type of recharge to the karst aquifer, and it does not include the recharge in terms of quantity or location. Based on Doerfliger et al. (1999), the I factor has been divided into four categories (from I1 to I4) (see Figure 3-6), according to the infiltration condition (concentrated to diffuse infiltration).

4. Karst network development (K): This factor reflects the presence or absence of a karstic network, as well as the development degree of that network (Doerfliger and Zwahlen 1998). According to Doerfliger et al. (1999), the karst network is "a network of solution openings greater than $10 \mathrm{~mm}$ in diameter or width". The $\mathrm{K}$ factor has been divided into three main categories (see Figure 3-6) based on the development of the karst network within the area as follow: well developed karst network (K1), poorly developed (K2), and mixed or fissured aquifers (K3)). 


\begin{tabular}{|c|c|c|c|c|c|}
\hline \multicolumn{6}{|l|}{ Epikarst (E) } \\
\hline \multicolumn{4}{|c|}{ Epikarst } & \multicolumn{2}{|r|}{ Karst Morphological Features } \\
\hline \multicolumn{2}{|c|}{ Highly developed } & \multicolumn{2}{|c|}{ E1 } & \multicolumn{2}{|c|}{$\begin{array}{l}\text { Sinkholes, dolines, caves, karrenfields or outcrops with high } \\
\text { fracturing. }\end{array}$} \\
\hline \multicolumn{2}{|c|}{ Moderately developed } & \multicolumn{2}{|c|}{ E2 } & \multicolumn{2}{|c|}{$\begin{array}{l}\text { Intermediate zones in the alignment of dolines or dry valleys. } \\
\text { Outcrops with medium fracturing. }\end{array}$} \\
\hline \multicolumn{2}{|c|}{$\begin{array}{l}\text { Small or absent (rest of } \\
\text { the catchment) }\end{array}$} & \multicolumn{2}{|c|}{ E3 } & \multicolumn{2}{|c|}{$\begin{array}{l}\text { No karst morphological phenomena. } \\
\text { Low fracture density. }\end{array}$} \\
\hline \multicolumn{6}{|c|}{ Protective Cover $(\mathrm{P})$} \\
\hline \multirow{2}{*}{\multicolumn{2}{|c|}{ Protective Cover }} & \multicolumn{4}{|r|}{ Characterisations } \\
\hline & & \multicolumn{3}{|c|}{$\begin{array}{l}\text { A. Soil lying directly on } \\
\text { limestone or on some high } \\
\text { permeability coarse detritus } \\
\text { layers, e.g. rock debris, or } \\
\text { lateral glacial tills. }\end{array}$} & $\begin{array}{l}\text { B. Soil lying on low permeability geological } \\
\text { layers, e.g. lake silt or clays. }\end{array}$ \\
\hline \multirow{4}{*}{ Absent } & P1 & \multicolumn{3}{|c|}{$0-20 \mathrm{~cm}$ of soil } & $\begin{array}{l}0-20 \mathrm{~cm} \text { of soil on layers that have a thickness } \\
\text { of less than } 1 \mathrm{~m} .\end{array}$ \\
\hline & P2 & \multicolumn{3}{|c|}{$20-100 \mathrm{~cm}$ of soil } & $\begin{array}{l}20-100 \mathrm{~cm} \text { of soil on layers that have a } \\
\text { thickness of less than } 1 \mathrm{~m} \text {. }\end{array}$ \\
\hline & P3 & \multicolumn{3}{|c|}{$100-200 \mathrm{~cm}$ of soil } & $\begin{array}{l}<100 \mathrm{~cm} \text { of soil or }>100 \mathrm{~cm} \text { of soil and } \\
>100 \mathrm{~cm} \text { of layers of low permeability. }\end{array}$ \\
\hline & P4 & \multicolumn{3}{|c|}{$>200 \mathrm{~cm}$} & $\begin{array}{l}>100 \mathrm{~cm} \text { of soil and thick detritus layers of } \\
\text { very low hydraulic conductivity or }>8 \mathrm{~m} \text { of clay } \\
\text { and clayey silt. }\end{array}$ \\
\hline \multicolumn{6}{|l|}{ Infiltration (I) } \\
\hline \multicolumn{2}{|c|}{ Infiltration Condition } & \multicolumn{4}{|r|}{ Characterisation } \\
\hline \multirow{4}{*}{ 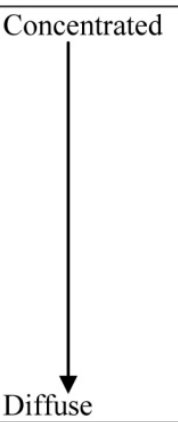 } & I1 & \multicolumn{4}{|c|}{$\begin{array}{l}\text { Perennial or temporarily losing streams - perennial or temporary stream feeding a } \\
\text { swallow hole or a sinkhole (doline) - water catchment areas of these above- } \\
\text { mentioned streams, including artificial drainage systems. }\end{array}$} \\
\hline & $\mathrm{I} 2$ & \multicolumn{4}{|c|}{$\begin{array}{l}\text { Water catchment areas of streams in I1 (without artificial drainage systems) with a } \\
\text { slope greater than } 10 \% \text { for cultivated areas and } 25 \% \text { for meadows and pastures. }\end{array}$} \\
\hline & $\mathrm{I} 3$ & \multicolumn{4}{|c|}{$\begin{array}{l}\text { Water catchment areas of the I1 stream (without artificial drainage systems) } \\
\text { whose slope is less than: } \\
10 \% \text { for cultivated areas and } 25 \% \text { for meadows and pastures. Low relief areas } \\
\text { collecting runoff water and slopes feeding those low areas (slope higher than: } 10 \% \\
\text { for cultivated sectors and } 25 \% \text { for meadows and pastures). }\end{array}$} \\
\hline & I4 & \multicolumn{4}{|c|}{ The rest of the catchment. } \\
\hline \multicolumn{6}{|c|}{ Karst Network Development (K) } \\
\hline \multicolumn{4}{|c|}{\begin{tabular}{|c|} 
Karst Network \\
\end{tabular}} & \multicolumn{2}{|r|}{ Characterisation } \\
\hline \multicolumn{3}{|c|}{ Well-developed karst network } & $\mathrm{K} 1$ & $\begin{array}{l}\text { Presence of a } \\
\text { decimetre to me } \\
\text { well connected). }\end{array}$ & $\begin{array}{l}\text { well-developed karst network (network with } \\
\text { re sized channels that are rarely plugged and are }\end{array}$ \\
\hline \multicolumn{3}{|c|}{$\begin{array}{l}\text { Poorly-developed karst } \\
\text { network }\end{array}$} & $\mathrm{K} 2$ & $\begin{array}{l}\text { Presence of a } 1 \\
\text { network, a poorl } \\
\text { decimetre or sme }\end{array}$ & $\begin{array}{l}\text { oorly-developed karst network (small conduits } \\
\text { y connected or filled network, or a network with } \\
\text { ller sized openings). }\end{array}$ \\
\hline \multicolumn{3}{|c|}{ Mixed or fissured aquifer } & K3 & $\begin{array}{l}\text { Presence of a sp } \\
\text { only fissured aqu }\end{array}$ & $\begin{array}{l}\text { ring emerging through porous terrain. Non-karst, } \\
\text { ifer. }\end{array}$ \\
\hline
\end{tabular}

Figure 3-6: Standard classification for EPIK parameters (Doerfliger et al. 1999).

The overall protection index (F) for EPIK method is calculated using the following formula, where a low $\mathrm{F}$ value corresponds to high vulnerability areas:

$$
F=\alpha E+\beta P+\gamma I+\delta K
$$


Table 3-3 represents the standard rates for the EPIK parameter categories and Table 3-4 represents the standard weighting coefficient for the EPIK parameters.

Table 3-3: Standard rates for the EPIK parameters (Doerfliger et al. 1999).

\begin{tabular}{|c|c|c|c|c|c|c|c|c|c|c|c|c|c|}
\hline \multicolumn{4}{|c|}{ Epikarst } & \multicolumn{4}{|c|}{ Protective Cover } & \multicolumn{3}{c|}{ Infiltration Condition } & \multicolumn{3}{c|}{ Karst Network } \\
\hline E1 & E2 & E3 & P1 & P2 & P3 & P4 & I1 & I2 & I3 & I4 & K1 & K2 & K3 \\
\hline 1 & 3 & 4 & 1 & 2 & 3 & 4 & 1 & 2 & 3 & 4 & 1 & 2 & 3 \\
\hline
\end{tabular}

Table 3-4: Standard weighting coefficient for the EPIK parameters (Doerfliger et al. 1999).

\begin{tabular}{|c|c|c|c|}
\hline Epikarst & Protective Cover & $\begin{array}{c}\text { Infiltration } \\
\text { Condition }\end{array}$ & Karst Network \\
\hline $\boldsymbol{\alpha}$ & $\boldsymbol{\beta}$ & $\boldsymbol{\gamma}$ & $\boldsymbol{\delta}$ \\
\hline 3 & 1 & 3 & 2 \\
\hline
\end{tabular}

Based on the weights and rates for the protection index (F) calculations, the protection index (F) can obtain values ranging from (9-34). Table 3-5 shows the vulnerability classes based on the protection index (F) values, and Table 3-6 represents the various possible combinations for the F factor (protection index values).

Table 3-5: Vulnerability classes for the EPIK method based on the protection index (F) (Doerfliger and Zwahlen 1998).

\begin{tabular}{|c|c|}
\hline Vulnerability Areas & Protection Index (F) \\
\hline Very high & F between 9 and 19 \\
\hline High & F between 20 and 25 \\
\hline Moderate & F higher than 25 \\
\hline Low & F $>25$ with the presence of $\mathrm{P}_{4}+\left(\mathrm{I}_{3,4}\right)$ categories \\
\hline
\end{tabular}


Table 3-6: Possible protection index (F) values for the EPIK vulnerability assessment method (Doerfliger and Zwahlen 1998).

\begin{tabular}{|c|c|c|c|c|c|c|c|c|c|c|c|c|}
\hline$K 1=1$ & \multicolumn{3}{|c|}{$I 1=1$} & \multicolumn{3}{|c|}{$I 2=2$} & \multicolumn{3}{|c|}{$I 3=3$} & \multicolumn{3}{|c|}{$I 4=4$} \\
\hline & E1 $=1$ & $E 2=3$ & E3 $=4$ & E1 $=1$ & $E 2=3$ & $E 3=4$ & E1 $=1$ & $E 2=3$ & $E 3=4$ & E1 $=1$ & $E 2=3$ & $E 3=4$ \\
\hline$P 1=1$ & 9 & 15 & 18 & 12 & 18 & 21 & 15 & 21 & 24 & 18 & 24 & 27 \\
\hline $\mathbf{P 2}=\mathbf{2}$ & 10 & 16 & 19 & 13 & 19 & 22 & 16 & 22 & 25 & 19 & 25 & 28 \\
\hline $\mathbf{P 3}=\mathbf{3}$ & & 17 & 20 & 14 & 20 & 23 & 17 & 23 & 26 & 20 & 26 & 29 \\
\hline$P 4=4$ & & 18 & 21 & 15 & 21 & 24 & 18 & 24 & 27 & 21 & 27 & 30 \\
\hline$K 2=2$ & \multicolumn{3}{|c|}{$I 1=1$} & \multicolumn{3}{|c|}{$I 2=2$} & \multicolumn{3}{|c|}{ I3 $=3$} & \multicolumn{3}{|c|}{ I4 $=4$} \\
\hline & E1 $=1$ & $\mathbf{E} 2=3$ & $\mathrm{E3}=4$ & E1 $=1$ & $E 2=3$ & $E 3=4$ & E1 $=1$ & $E 2=3$ & $\mathrm{E3}=4$ & E1 $=1$ & $E 2=3$ & $E 3=4$ \\
\hline$P 1=1$ & 11 & 17 & 20 & 14 & 20 & 23 & 17 & 23 & 26 & 20 & 26 & 29 \\
\hline $\mathbf{P} 2=\mathbf{2}$ & 12 & 18 & 21 & 15 & 21 & 24 & 18 & 24 & 27 & 21 & 27 & 30 \\
\hline $\mathbf{P 3}=\mathbf{3}$ & & 19 & 22 & 16 & 22 & 25 & 19 & 25 & 28 & 22 & 28 & 31 \\
\hline$P 4=4$ & & 20 & 23 & 17 & 23 & 26 & 20 & 26 & 29 & 23 & 29 & 32 \\
\hline$K 1=3$ & \multicolumn{3}{|c|}{$I 1=1$} & \multicolumn{3}{|c|}{$I 2=2$} & \multicolumn{3}{|c|}{$I 3=3$} & \multicolumn{3}{|c|}{$I 4=4$} \\
\hline & E1 $=1$ & $E 2=3$ & $E 3=4$ & E1 $=1$ & $E 2=3$ & $\mathrm{E3}=4$ & $\mathbf{E} 1=1$ & E2 $=3$ & $\mathrm{E3}=4$ & E1 $=1$ & $\mathbf{E} 2=3$ & $\mathrm{E} 3=4$ \\
\hline$P 1=1$ & 13 & 19 & 22 & 16 & 22 & 25 & 19 & 25 & 28 & 22 & 28 & 31 \\
\hline $\mathbf{P 2}=\mathbf{2}$ & 14 & 20 & 23 & 17 & 23 & 26 & 20 & 26 & 29 & 23 & 29 & 32 \\
\hline $\mathbf{P 3}=\mathbf{3}$ & & 21 & 24 & 18 & 24 & 27 & 21 & 27 & 30 & 24 & 30 & 33 \\
\hline$P 4=4$ & & 22 & 25 & 19 & 25 & 28 & 22 & 28 & 31 & 25 & 31 & 34 \\
\hline
\end{tabular}

Non-existent situation in the field

Protection index values lower or equal to 19 (corresponding to S1 Protection zone (very high vulnerable areas))

Protection index values between 20 and 25 (corresponding to S2 Protection zone (high vulnerable areas))

Protection index values higher than 25 (corresponding to S3 Protection zone (moderate vulnerable areas))

Rest of the catchment $\left(\mathrm{F}>25\right.$ with the presence of $\mathrm{P}_{4}+\left(\mathrm{I}_{3,4}\right)$ category) (low vulnerable areas)) 


\subsubsection{Results and discussion}

\subsubsection{COP method factors results}

- C factor

Based on the study area characteristics and due to the absent of the swallow holes, scenario 2 was used. The slope map as a percentage was derived for the area based on the ASTER Digital Elevation Model 30 metre resolution (USGS 2014b). The land-cover map for the study area was based on the Land-Sat 8 satellite image (USGS 2014a) and classified based on the vegetation cover availability to high and low vegetation cover. The slope map (as a percentage) was intersected with the land-cover map for the study area and classified based on Figure 3-5,Table XI to obtain the sv (slope and vegetation) map.

Based on the karstic features within the study area and the surface features permeability (Figure 3-5, Table X), the following values were assumed for the surface features (sf) layer:

- value 0.25: developed karst with the absence of surface features.

- value 0.75: scarcely developed or dissolution features with permeable surface features

- value 1: non-karstic terrain.

The final $\mathrm{C}_{\mathrm{SCORE}}$ has been calculated as $\mathrm{C}_{\mathrm{SCORE}}=\mathrm{sf} . \mathrm{sv}$, and classified based on Figure 3-5, Table XII. The $\mathrm{C}_{\mathrm{SCORE}}$ map shows that the study area ranges from a very high to a very low reduction of protection areas (Figure 3-7). 


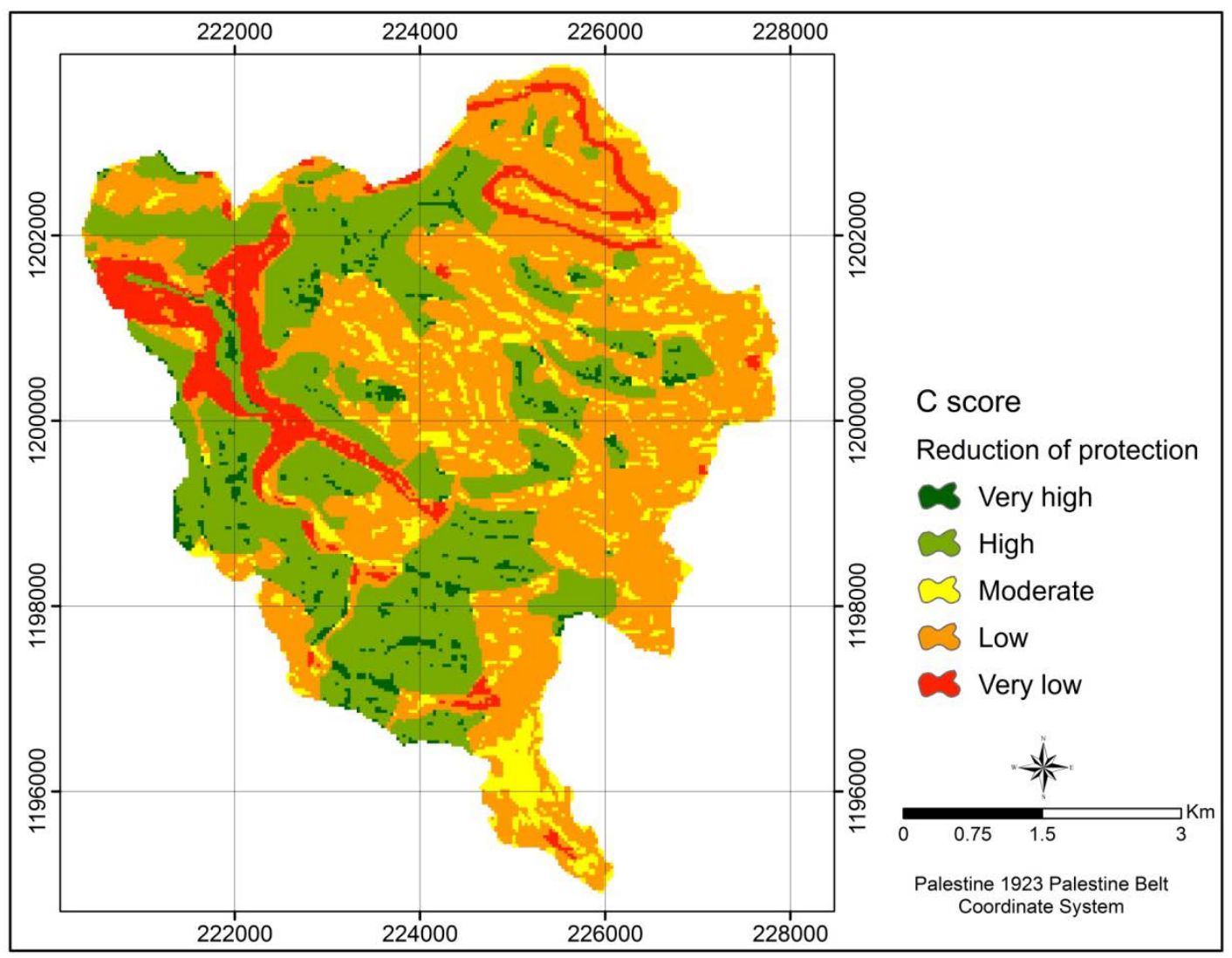

Figure 3-7: $C_{S C O R E}$ map for the study area.

\section{- O factor}

In order to determine the $\mathrm{O}_{\mathrm{S}}$ sub-factor, a soil unit map with the soil texture description and estimated thickness of each unit (Ministry of Agriculture 1994) was used. Os was determined as having a clay soil texture with the thickness ranging between 0.49 and 0.75 metres. Based on Figure 3-5, Table II and the soil information, the $\mathrm{O}_{\mathrm{S}}$ has fixed values of three and four.

The $\mathrm{O}_{\mathrm{L}}$ sub-factor was calculated in two parts based on three parameters (Figure 3-5, Tables IIIV): (1) lithology and fracturation (ly), (2) thickness of the unsaturated zone (m), and (3) confining condition (cn). The first part represents the layer index, which was calculated follows: layer index $=\Sigma$ (ly.m) based on the rock type and the thickness of the unsaturated zone of each 
layer. On the other hand, the second part was calculated as: (the value layer index . cn), which represents the $\mathrm{O}_{\mathrm{L}}$ as a final product. All the layers were assumed to be unconfined layers, and the COP method in this study was applied to the outcropping layers. Figure 3-8 represents the $\mathrm{O}_{\mathrm{SCORE}}$ map, which is a result of the summation of the $\mathrm{O}_{\mathrm{S}}$ and $\mathrm{O}_{\mathrm{L}}$ sub-factors. Based on the $\mathrm{O}_{\text {SCORE }}$ values, the protection values can be considered moderate to very high within the study area.

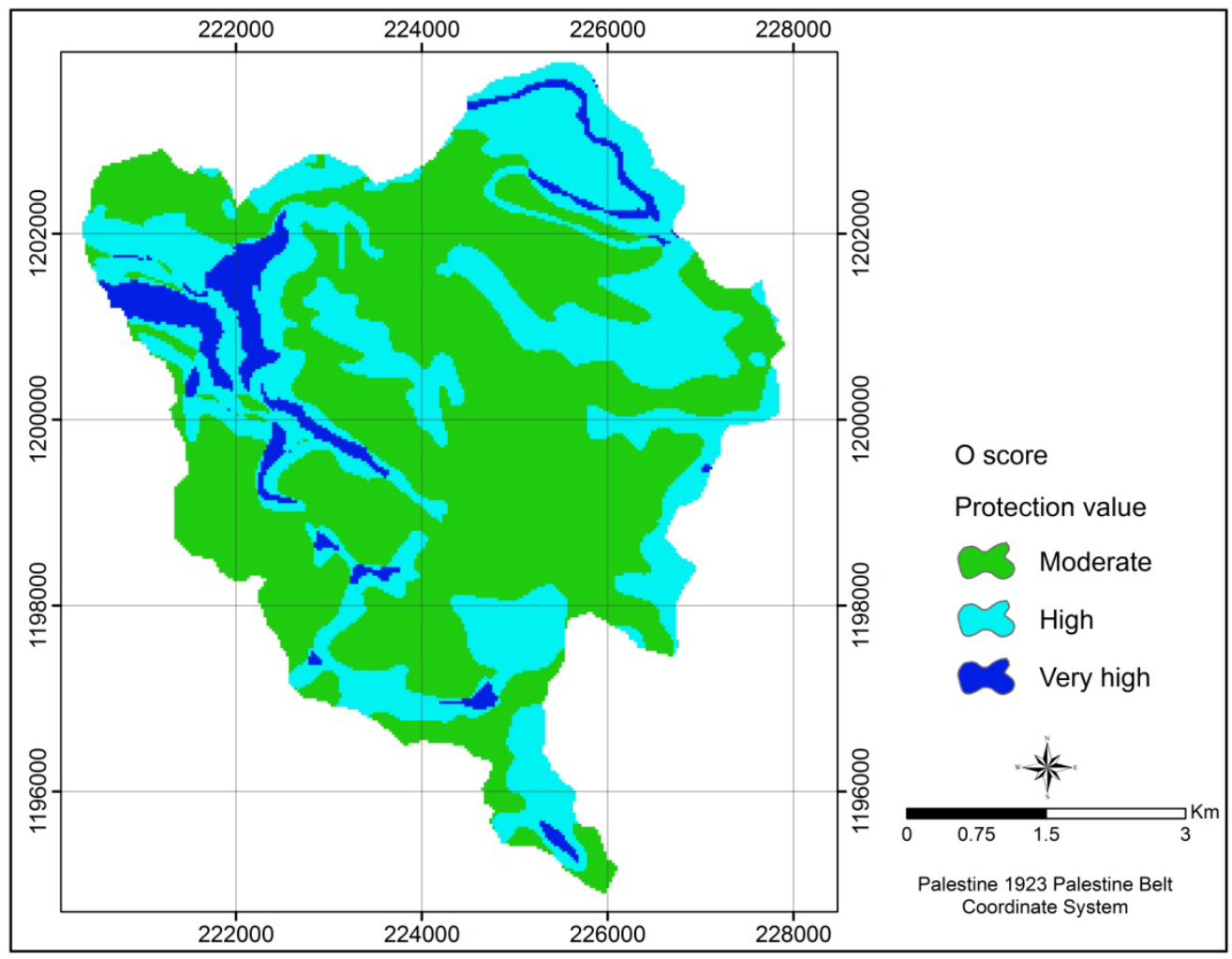

Figure 3-8: $O_{S C O R E}$ map of the study area.

\section{- P factor}

Daily rainfall data from 1968/1969 and 2012/2013 (water years from October until May) from the meteorological station AH0003 (MWI 2013) were used in order to calculate the P factor. The calculated long-term yearly average for the station AH0003 was $552.2 \mathrm{~mm} / \mathrm{yr}$. The wet years were calculated to be equal or greater than $635 \mathrm{~mm} / \mathrm{yr}$. The average rainfall for the wet years was 
around $759 \mathrm{~mm} / \mathrm{yr}$ (Table 3-7). Based on the daily rainfall data for the same station, the average number of rainy days was around 54 day/yr (water years).

Table 3-7: The long-term average yearly rainfall for the station AH0003 from 1968/1969 and 2012/2013 (wet year).

\begin{tabular}{|c|c|c|c|c|c|}
\hline Year & $\begin{array}{l}\text { Yearly rainfall } \\
\text { amount (mm) }\end{array}$ & Year & $\begin{array}{l}\text { Yearly rainfall } \\
\text { amount (mm) }\end{array}$ & Year & $\begin{array}{l}\text { Yearly rainfall } \\
\text { amount (mm) }\end{array}$ \\
\hline $1968 / 1969$ & 693.0 & $1983 / 1984$ & 468.6 & 1998/1999 & 264.7 \\
\hline $1969 / 1970$ & 554.4 & $1984 / 1985$ & 494.3 & 1999/2000 & 550.1 \\
\hline 1970/1971 & 638.2 & 1985/1986 & 444.7 & $2000 / 2001$ & 437.9 \\
\hline 1971/1972 & 572.3 & 1986/1987 & 670.1 & $2001 / 2002$ & 656.3 \\
\hline 1972/1973 & 289.2 & 1987/1988 & 691.4 & $2002 / 2003$ & 933.3 \\
\hline $1973 / 1974$ & 563.6 & $1988 / 1989$ & 449.3 & $2003 / 2004$ & 459.7 \\
\hline $1974 / 1975$ & 439.7 & 1989/1990 & 532.2 & $2004 / 2005$ & N/A \\
\hline $1975 / 1976$ & 474.9 & 1990/1991 & 495.1 & $2005 / 2006$ & N/A \\
\hline $1976 / 1977$ & 494.0 & 1991/1992 & 1151.4 & 2006/2007 & 595.0 \\
\hline $1977 / 1978$ & 439.3 & 1992/1993 & 615.3 & $2007 / 2008$ & 338.6 \\
\hline 1978/1979 & 284.8 & 1993/1994 & 543.6 & $2008 / 2009$ & 535.4 \\
\hline 1979/1980 & 586.0 & 1994/1995 & 607.4 & $2009 / 2010$ & 530.5 \\
\hline 1980/1981 & 478.4 & 1995/1996 & 487.2 & 2010/2011 & 527.6 \\
\hline $1981 / 1982$ & 469.1 & 1996/1997 & 707.1 & 2011/2012 & 598.1 \\
\hline 1982/1983 & 527.1 & 1997/1998 & 744.3 & $2012 / 2013$ & 710.9 \\
\hline \multicolumn{6}{|c|}{$\begin{array}{ll}\text { Average rainfall } & 552 \mathrm{~mm} / \mathrm{yr} \\
\end{array}$} \\
\hline \multicolumn{6}{|c|}{ 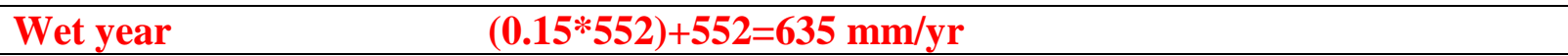 } \\
\hline \multicolumn{6}{|c|}{ Average rainfall for the wet years $\quad 759.6 \mathrm{~mm} / \mathrm{yr}$} \\
\hline \multicolumn{6}{|c|}{ Average number of rainy days $\quad 54$} \\
\hline
\end{tabular}

According to the average rainfall amount for the wet years, and based on Figure 3-5, Tables XIII and XIV, the $\mathrm{P}_{\mathrm{Q}}$ value was 0.3 . The temporal distribution of the rainfall $\left(\mathrm{P}_{\mathrm{I}}\right)$ was calculated by dividing the average yearly rainfall with the average number of rainy days per year as follows: $552 / 54=10.2 \mathrm{~mm} / \mathrm{d}$. Based on the temporal distribution amount $(10.2 \mathrm{~mm} / \mathrm{d})$, the $P_{I}$ value was 0.4. Based on the $\mathrm{P}_{\mathrm{Q}}$ and $\mathrm{P}_{\mathrm{I}}$ values, the study area will have a fixed $\mathrm{P}_{\mathrm{SCORE}}$ as follows: $\mathrm{P}_{\mathrm{SCORE}}=$ $\mathrm{P}_{\mathrm{Q}}+\mathrm{P}_{\mathrm{I}}=0.3+0.4=0.7$. According to the $\mathrm{P}_{\mathrm{SCORE}}$ value of 0.7 , the reduction of protection for the $\mathrm{P}_{\mathrm{SCORE}}$ can be considered moderate (Figure 3-5, Table XV). 


\subsubsection{EPIK method factors results}

The EPIK factor layers for the study area were prepared based on the field survey, which was conducted in the study for the karst features and karst network. Other data layers (soil, geology, land cover, etc.) were prepared and collected for the study area from existing data sources (see Table 3-2). The epikarst layer was divided into three subgroups E1, E2 and E3 based on the development of the epikarst. Figure 3-9 represents the epikarst (E) factor map for the study area.

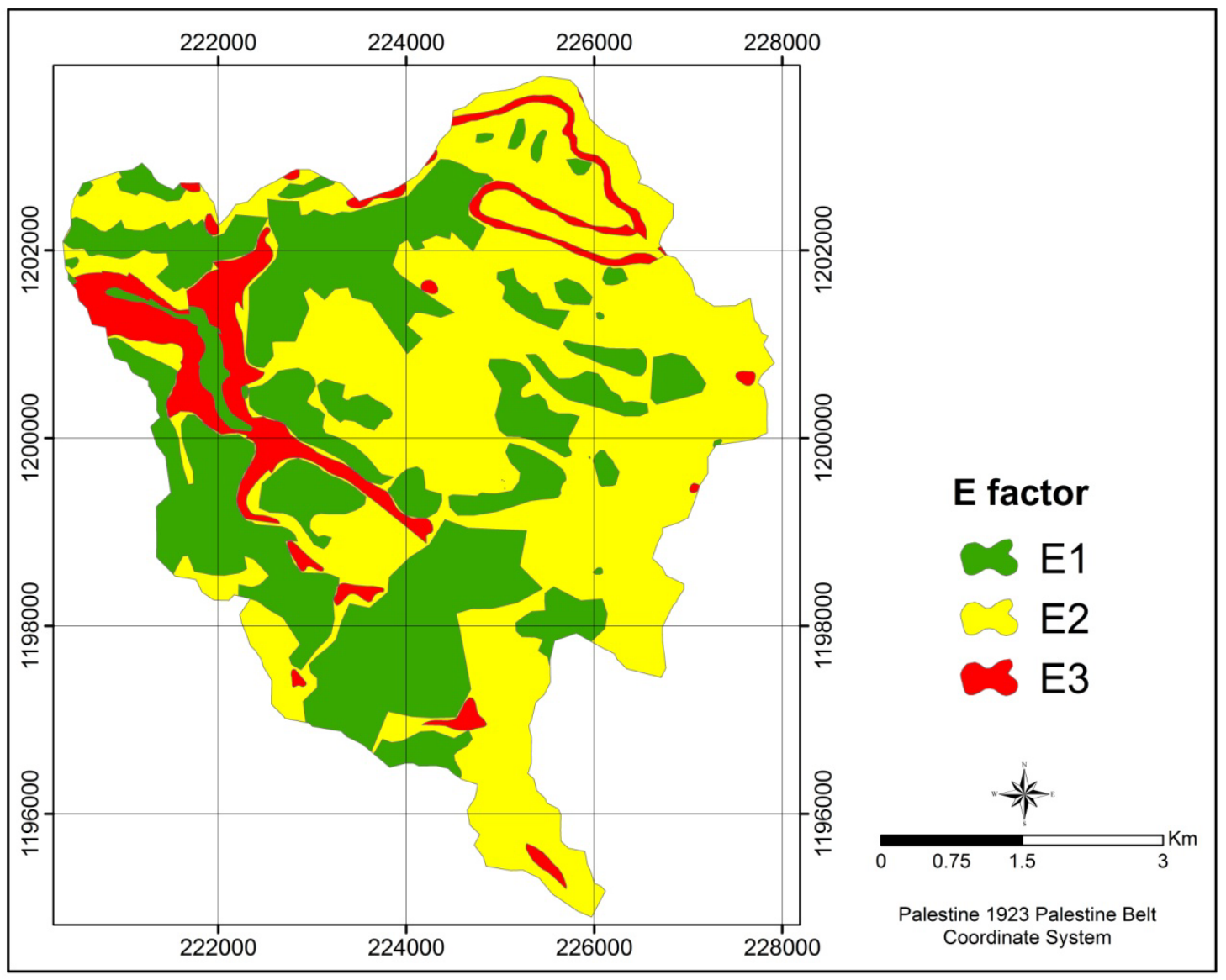

Figure 3-9: Epikarst (E) factor map for the study area.

The P factor for the study area was determined using different types of data, including:

- soil depth information from the study area soil map.

- data and pictures from the field trip done within the study area.

- Google Earth maps. 
All information mentioned above was used, which helped to determine the $\mathrm{P}$ factor, and especially (P1) areas, where the soil thicknesses was very thin $(0-20 \mathrm{~cm})$. Figure 3-10 represents the protective cover (P) factor for the study area, where P1 and P2 sub-factors are available within the study area.

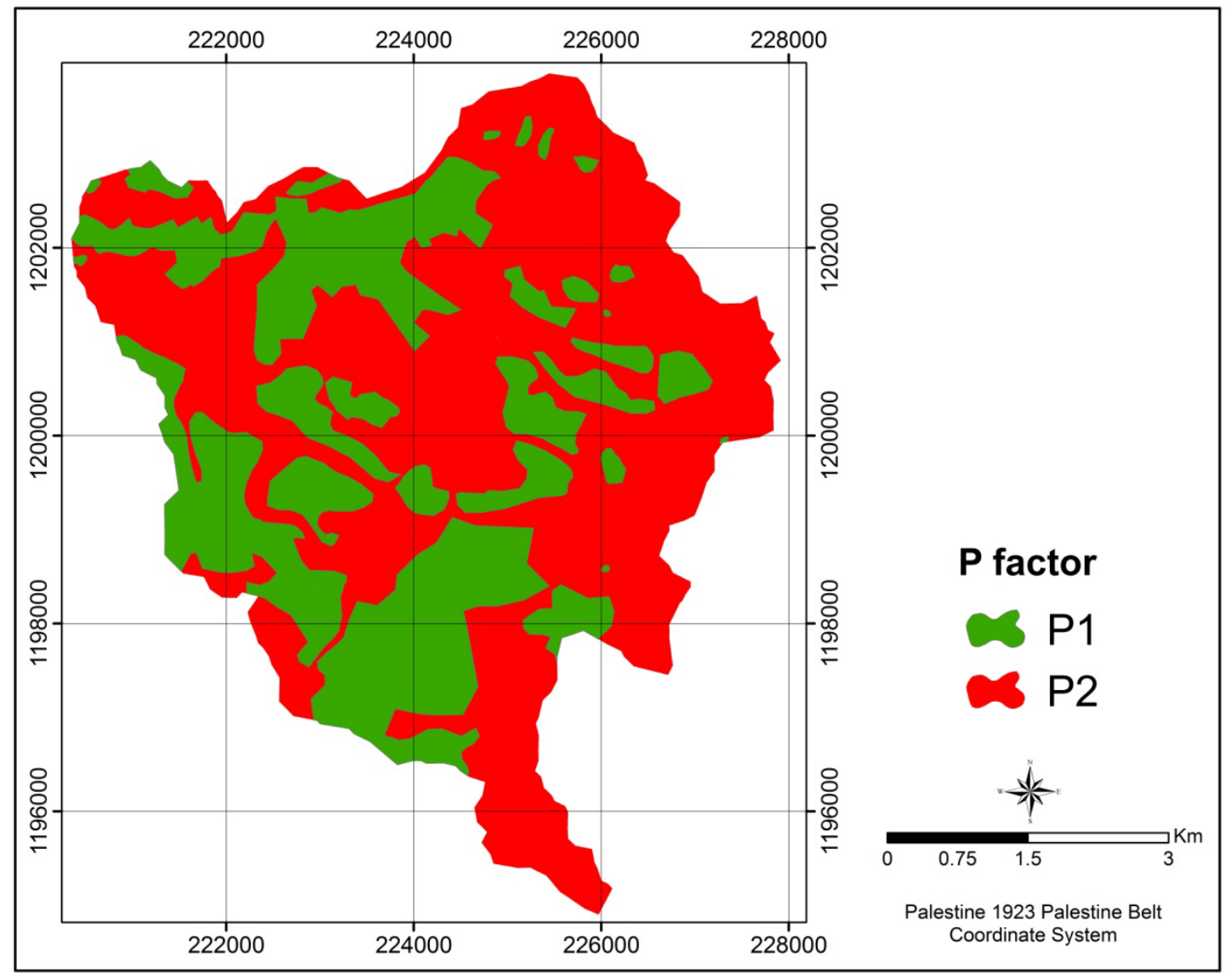

Figure 3-10: Protective cover (P) factor map for the study area.

Related to the infiltration condition, the I4 sub-factor was assumed for the whole catchment. The karst network development sub-factors for the catchment were divided into three sub-factors according to the degree of the karst network development. Figure 3-11 represents the karst network development $(\mathrm{K})$ map, where $\mathrm{K} 1$ represents the areas with highly developed karst networks, and $\mathrm{k} 3$ represents the non-karst areas (only fissured aquifers). 


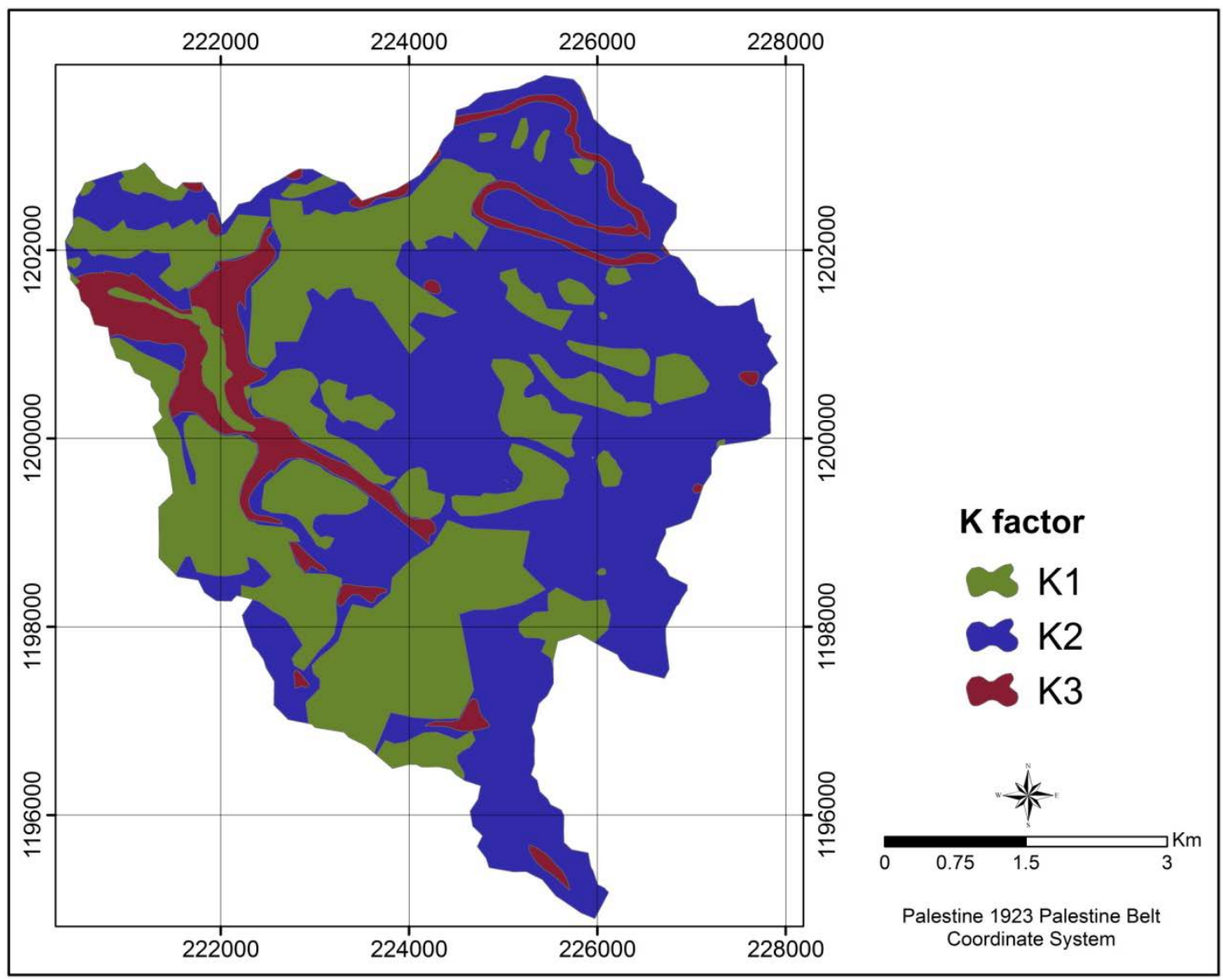

Figure 3-11: Karst network development (K) map for the study area.

\subsubsection{Final COP and EPIK vulnerability assessment maps}

After preparing all required factors for both COP and EPIK vulnerability assessment methods in a digital format using ArcGIS software, the final calculation was done based on the equations for COP (COP index $\left.=\mathrm{C}_{\text {SCORE }} \cdot \mathrm{O}_{\mathrm{SCORE}} \cdot \mathrm{P}_{\mathrm{SCORE}}\right)$ and EPIK $(\mathrm{F}=\alpha \mathrm{E}+\beta \mathrm{P}+\gamma \mathrm{I}+\delta \mathrm{K})$ methods in order to obtain the final vulnerability map from both of these methods.Figure 3-12 and Figure 3-13 represent the final COP and EPIK groundwater vulnerability assessment maps for the study area, respectively. 


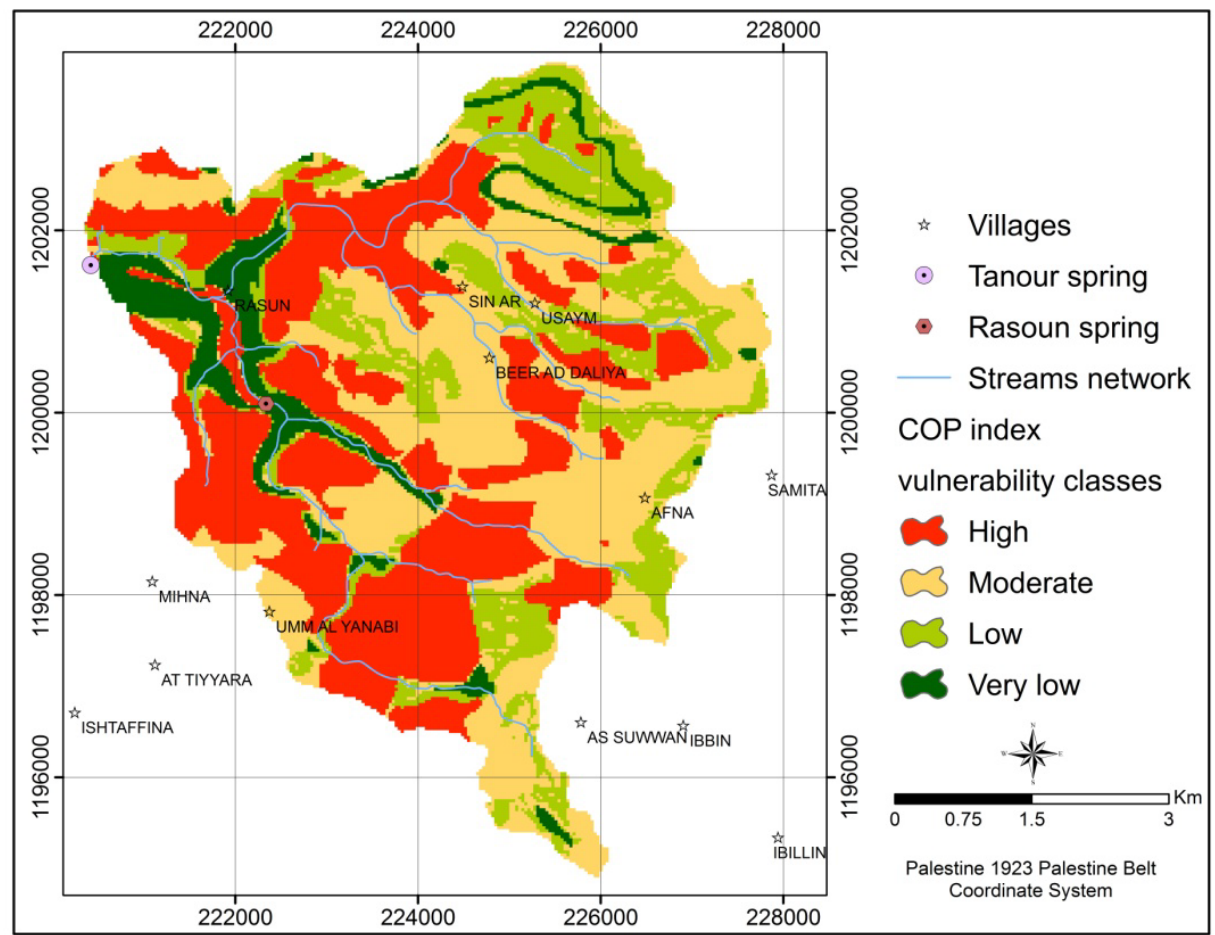

Figure 3-12: COP groundwater vulnerability assessment map for the study area.

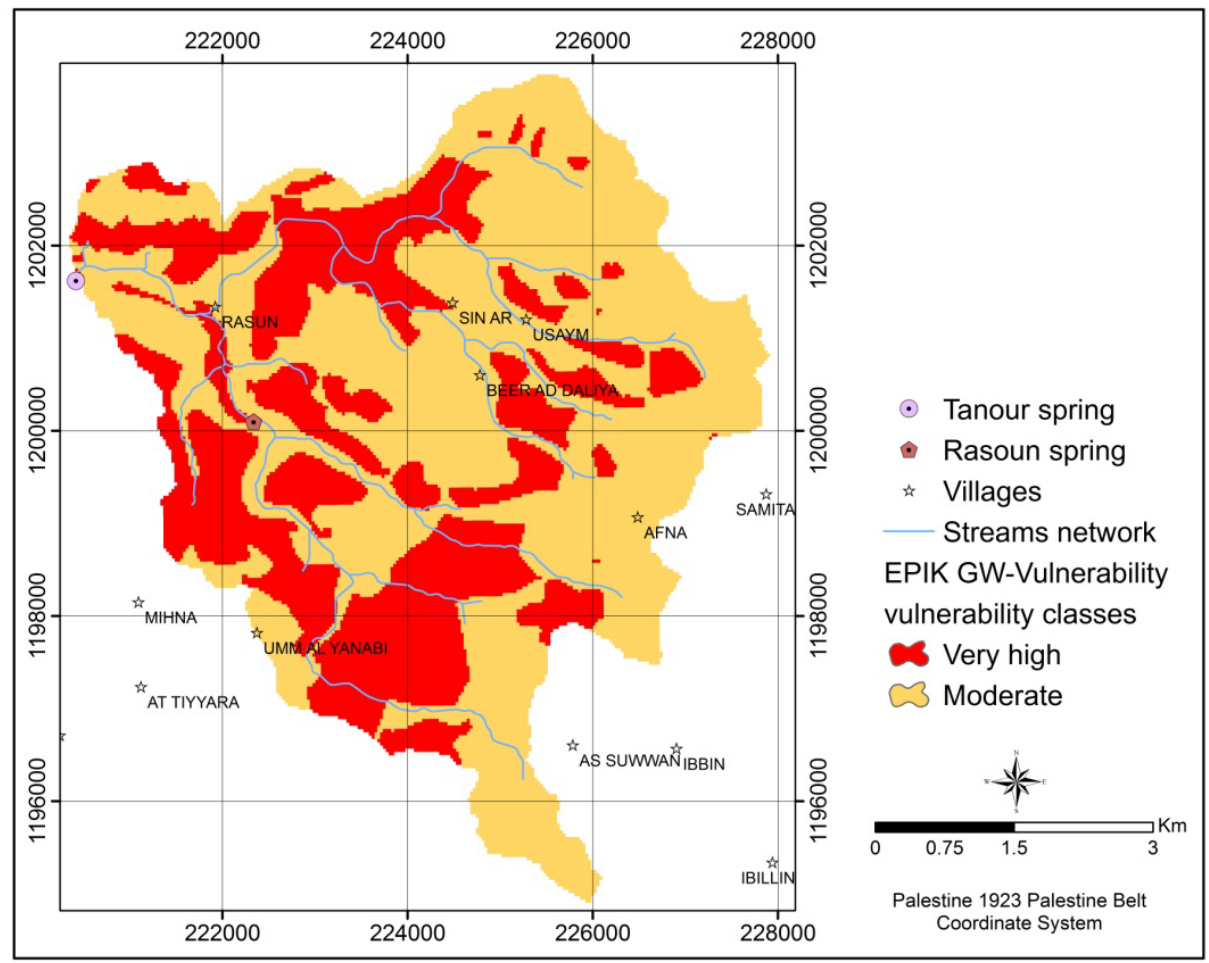

Figure 3-13: EPIK groundwater vulnerability assessment map for the study area. 
Based on the final vulnerability assessment maps for COP and EPIK, the area for each vulnerability class was calculated. For the EPIK method, the area of the very high vulnerability class was $\left(13.8 \mathrm{~km}^{2}\right)$, compared to the moderate vulnerability class, which was $\left(22.1 \mathrm{~km}^{2}\right)$. On the other hand, the area for the COP vulnerability classes was calculated as follows: high vulnerability $\left(13.3 \mathrm{~km}^{2}\right)$, moderate vulnerability $\left(12.5 \mathrm{~km}^{2}\right)$, low vulnerability $\left(7.2 \mathrm{~km}^{2}\right)$, and very low vulnerability $\left(2.9 \mathrm{~km}^{2}\right)$. Figure $3-14$ represent the vulnerability class percentages in both COP and EPIK vulnerability assessment methods.

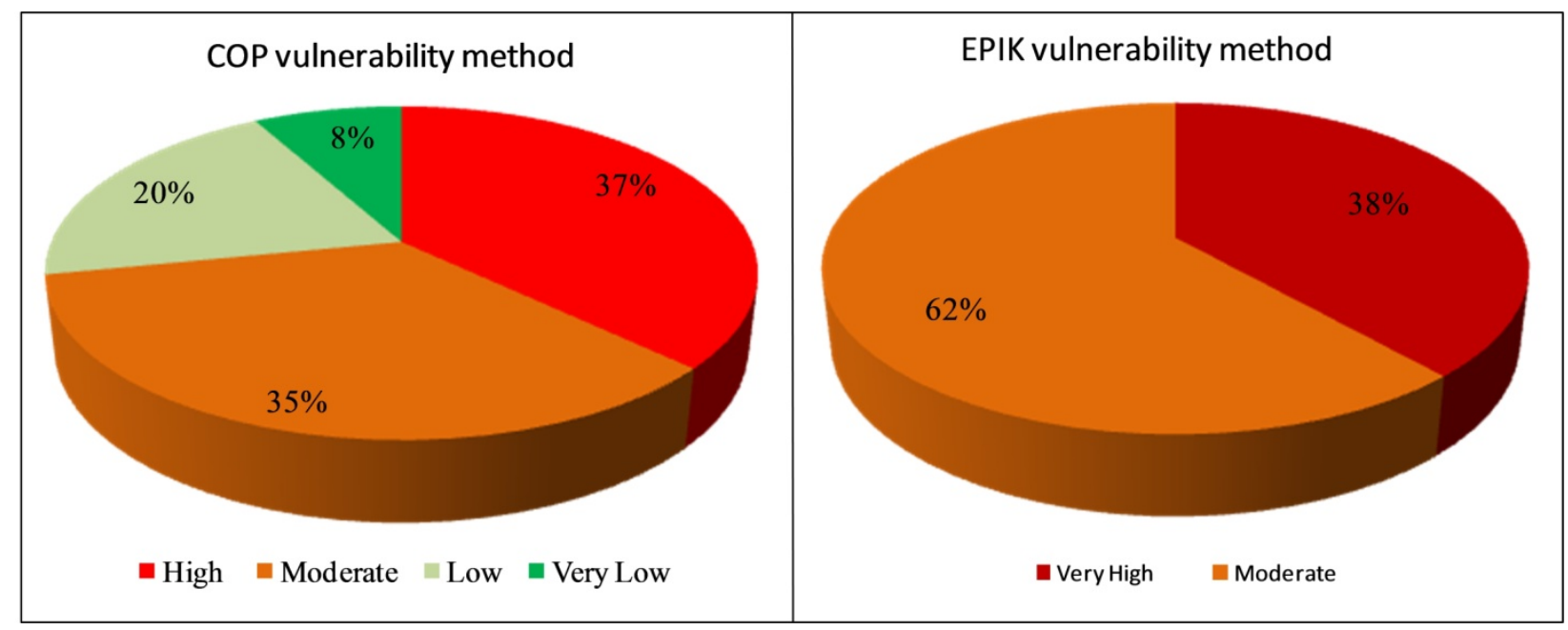

Figure 3-14: Vulnerability class percentages; (a) COP vulnerability assessment method, (b) EPIK vulnerability assessment method.

From the final vulnerability assessment maps, it can be noticed that, in the EPIK method, there are only two vulnerability classes available (very high and moderate), compared to the COP method, where four vulnerability classes are available (high, moderate, low and very low). In the COP method, the $\mathrm{O}$ factor considers the lithology and thickness of the unsaturated zone as well as the confining conditions, which is not considered in the EPIK method. For example, in the COP method, the non-karstic formations (like marl and marly limestone geological formations) are classified as areas of very low vulnerability. However, in the EPIK method, this is not differentiated, so that these areas are considered as moderately vulnerable. In addition, the COP method considers the quantity $\left(\mathrm{P}_{\mathrm{Q}}\right)$ and the temporal distribution $\left(\mathrm{P}_{\mathrm{I}}\right)$ of the precipitation within the catchment area, while in the EPIK method the precipitation quantity and temporal distribution are neglected. 
Both EPIK and COP methods consider karst feature availability and karst network development within the study area by determining the $\mathrm{C}$ factor in the COP method and the $\mathrm{E}$ and $\mathrm{K}$ factors in the EPIK method. Determining these factors requires a highly detailed field work survey for the karst features and karst network within the study area, which is sometimes difficult due to, for example, the size of the study area (very wide), the difficulty of reaching parts of the study area, the high cost, the amount of time, etc.

The COP method allows many factors to be easily obtained (precipitation, soil, geological data, etc.), and is more applicable than EPIK for different hydrogeological settings; EPIK is only suitable for pure karstic environments.

A direct comparison (through the intersection command in ArcGIS) between both, the COP and EPIK vulnerability maps with the land cover map (see Figure 2-7) was applied. Table 3-8 represents the intersection percentages between each land cover type and each vulnerability class in the COP and EPIK vulnerability assessment maps.

Table 3-8: Intersection percentages between each land cover type within the catchment and vulnerability classes for both, COP and EPIK vulnerability assessment maps.

\begin{tabular}{|c||c|c|c|c||c|c|}
\hline \multicolumn{1}{|c||}{ Land cover type } & \multicolumn{4}{c||}{ COP (\%) } & \multicolumn{2}{c|}{ EPIK (\%) } \\
\cline { 2 - 7 } & High & Moderate & Low & Very low & Very high & Moderate \\
\hline Bare and low dense trees & 11.6 & 28.0 & 15.0 & 5.8 & 12.5 & 47.8 \\
\hline Urban & 0.5 & 3.5 & 2.5 & 1.1 & 0.6 & 7.1 \\
\hline Forest & 25.0 & 3.4 & 2.5 & 1.1 & 25.8 & 6.2 \\
\hline
\end{tabular}

From table Table 3-8 it is noticed that high vulnerable areas in the COP method and the very high vulnerable areas in EPIK method are presenting more than one third ( 38\%) of the catchment area. This high percentage, compared to the low share of low and very low vulnerability class areas (especially in the COP method) reflects the high sensitivity of the catchment area against contamination. This sensitivity is reflected by the high number of the pollution events that occurred in the Tanour and Rasoun springs during the past years, especially during the winter season, due to the high flow velocity in the karst system. 


\subsection{Travel time physics-based groundwater vulnerability assessment for non-point pollution sources in karst aquifers}

\subsubsection{Introduction}

Karst aquifers are especially sensitive to contamination because of direct recharge, short subsurface travel times, low storage capacity of the conduit system and often missing protective coverage. Several processes of natural attenuation including filtration, adsorption, and chemical or microbiological decay processes are little effective in karst systems (Zwahlen et al. 2003, Butscher and Huggenberger 2009) due to the short water-rock interaction processes.

Understanding groundwater pathways and movement within the epikarst is fundamental to evaluate pollution risks from point and non-point sources in karst aquifer systems. This is especially important in the context of the abstraction of groundwater for drinking water purposes. To assess the vulnerability of karst aquifers and effects of contaminations on groundwater resources in karst areas, lateral groundwater flow within the epikarst and groundwater travel times from each part of the catchment towards the surface water streams need to be evaluated.

The travel time (transit time) vulnerability assessment method is a physical approach, which is calculated based on the hydraulic properties of the perched epikarst saturated zone (hydraulic conductivity and effective porosity) and the hydraulic (slope) gradient. The required information on the temporal and spatial distribution and movement of groundwater through the epikarst (subsurface) from each point within the catchment towards the surface water stream network as a final receptor is obtained by integrating the flow path lengths with the lateral groundwater transport velocity (McGuire and McDonnell 2006, Brosig et al. 2008). The travel time of vertical infiltration between the surface dry valleys (wadis) and the groundwater table is considered negligible in comparison to the lateral travel time in the epikarst. Figure 3-15 shows a crosssectional conceptual diagram for the water flow within the epikarst, following the topographical gradient (relief) towards a stream (wadi) as a final recharge point, to reach after that the saturated zone directly through shafts and sinkholes as a concentrated flow. 


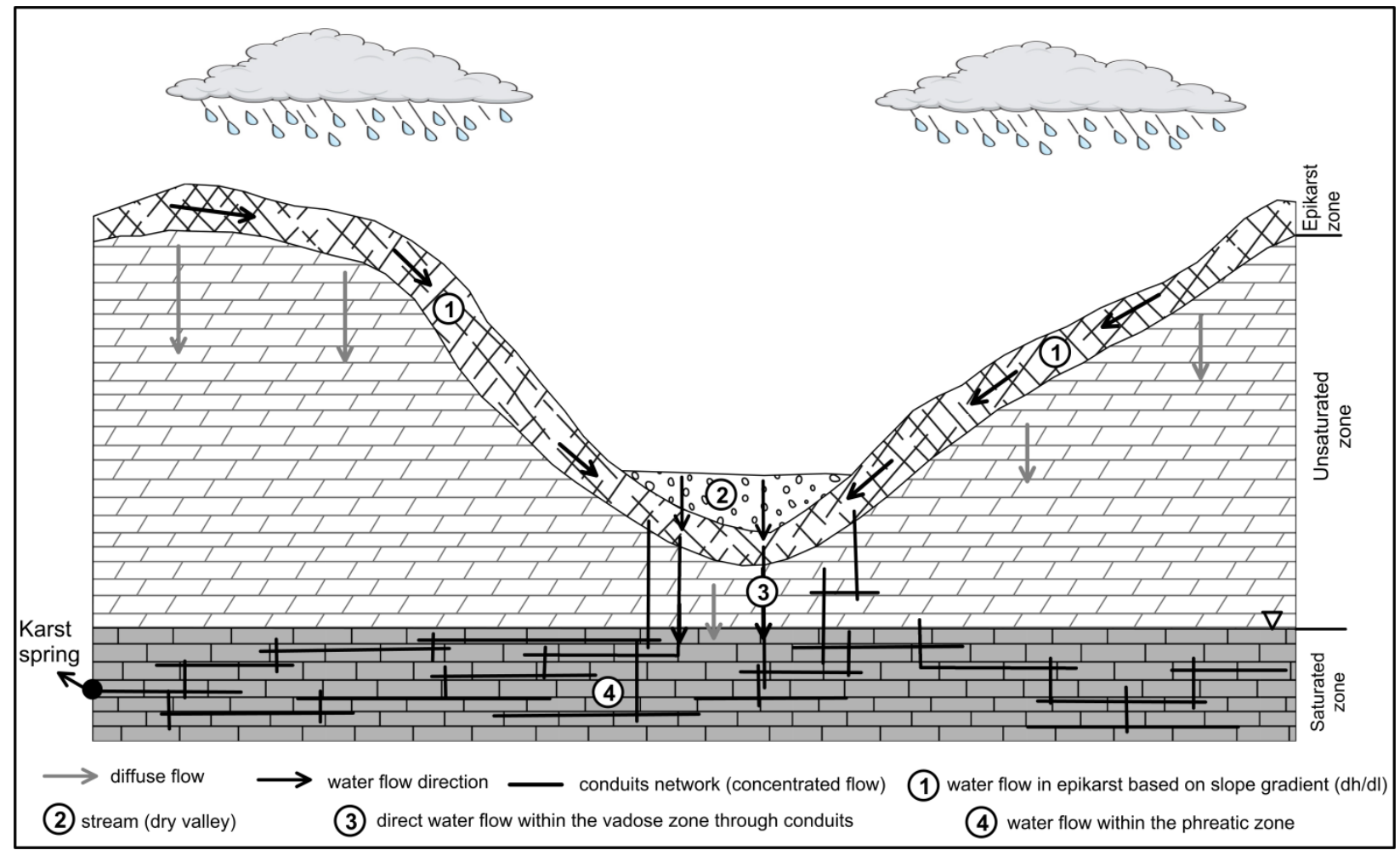

Figure 3-15: Cross-sectional conceptual diagram for water travel time within the epikarst towards a stream as a final recharge point (modified after Brosig et al. 2008).

Different studies used travel time models in order to assess pollutant movement and transport pathways. For example: Schilling and Wolter (2007) used the travel time approach in order to evaluate the stream nitrate concentration reductions to the groundwater travel time distribution in the catchment. In addition, Buchanan et al. (2013) used the travel time approach in order to identify the non-point phosphorous sources areas and transport pathways. Understanding the characteristics of groundwater flow (water flow pathways and transport velocity along these pathways) through the epikarst is essential for a vulnerability assessment when employing the travel time model. According to McGuire and McDonnell (2006) and Dosa et al. (2011), short groundwater travel times are associated with a low potential for biogeochemical reactions and degradation processes in the aquifer, therefore enabling pollutants to pass the subsurface system often at unacceptably high concentration levels.

This chapter aims to develop a spatially distributed travel time based vulnerability mapping methodology for karst aquifers based on travel times from each part of the catchment through the 
epikarst towards surface water streams as final receptors. To describe the underlying lateral groundwater flow within the epikarst, estimated hydraulic conductivity (using the base flow recession method for the spring discharge hydrograph), effective porosity, land surface gradient, and water flow path length were used. ArcGIS was employed to perform all the spatial calculations, using a regular grid cell size of $30 \mathrm{~m}$.

\subsubsection{Methodology}

\subsubsection{1. $\quad$ Physics-based travel time method}

To assess groundwater vulnerability to non-point source pollution, a groundwater travel time map of the Tanour and Rasoun spring catchment area was generated using ArcGIS 10.3 (ESRI 2015). Figure 3-16 shows the flow diagram of the applied approach. As basis for the map, digital elevation model (DEM) ASTER data, with a spatial resolution of 30 x 30 m (USGS 2014b) were used in order to extract the main surface water stream network. The "SetNull" command was used in order to generate a map with null value (no data) for streams, and with one for the rest of the catchment. According to the ASTER data set resolution, all calculations for the maps were performed using a grid cell size of 30 x $30 \mathrm{~m}$.

The calculated groundwater travel time $t[\mathrm{~d}]$ was determined by:

$$
t=\frac{s}{v_{a}}
$$

where, $s[\mathrm{~m}]$ represents the calculated flow respective transport path length from each grid cell within the catchment area toward the surface water streams as final recharge points, and $v_{a}[\mathrm{~m} / \mathrm{d}]$ is the average groundwater advective transport velocity within the epikarst towards the nearest stream location. Figure 3-17 shows examples of conceptual flow paths from different cells within the catchment towards the nearest stream location based on the groundwater flow direction for those cells. Values of $v_{a}$ were calculated as follows. At first, the groundwater transport velocity $v$ [m/d] was calculated independently cell by cell using:

$$
v=\frac{K}{n_{e}} * \frac{d h}{d l}
$$


where $K[\mathrm{~m} / \mathrm{d}]$ is the hydraulic conductivity, $n_{e}[-]$ the effective porosity, and $d h / d l[-]$ the hydraulic gradient, corresponding to the land slope gradient within the catchment area, calculated from the DEM data. The second calculation step was performed based on Schilling and Wolter (2007) by dividing the calculated flow length weighted by velocity $v$ (by using flow length tool in ArcGIS) over the flow length $s$, in order to obtain the average water flow velocity $v_{a}$ as a final result.

The $n_{e}$ value was estimated based on previous studies and literature sources as 2\% (MWI 2000, Hobler et al. 2001).

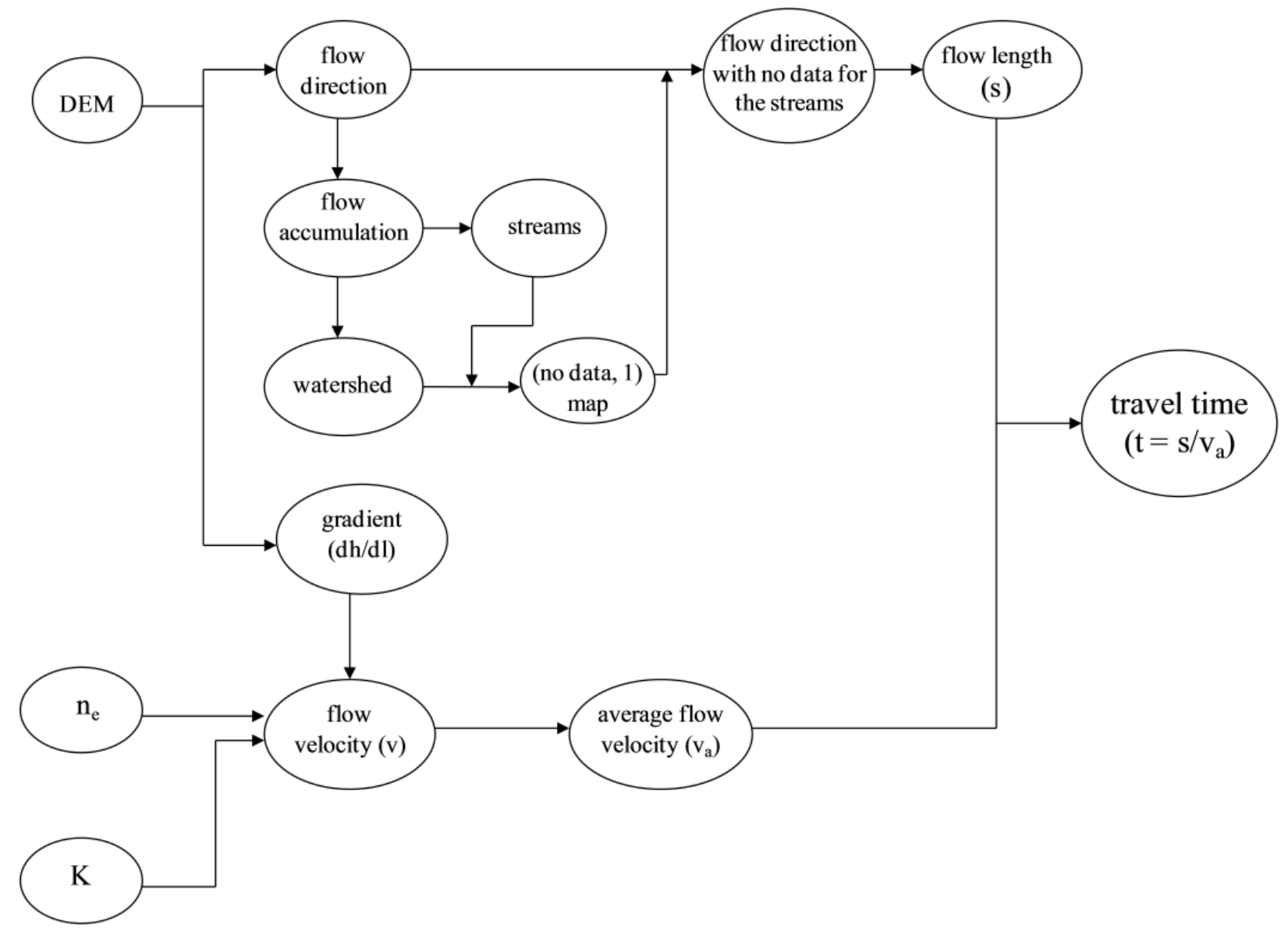

Figure 3-16: Flow diagram for the calculation of groundwater travel time within the catchment. 


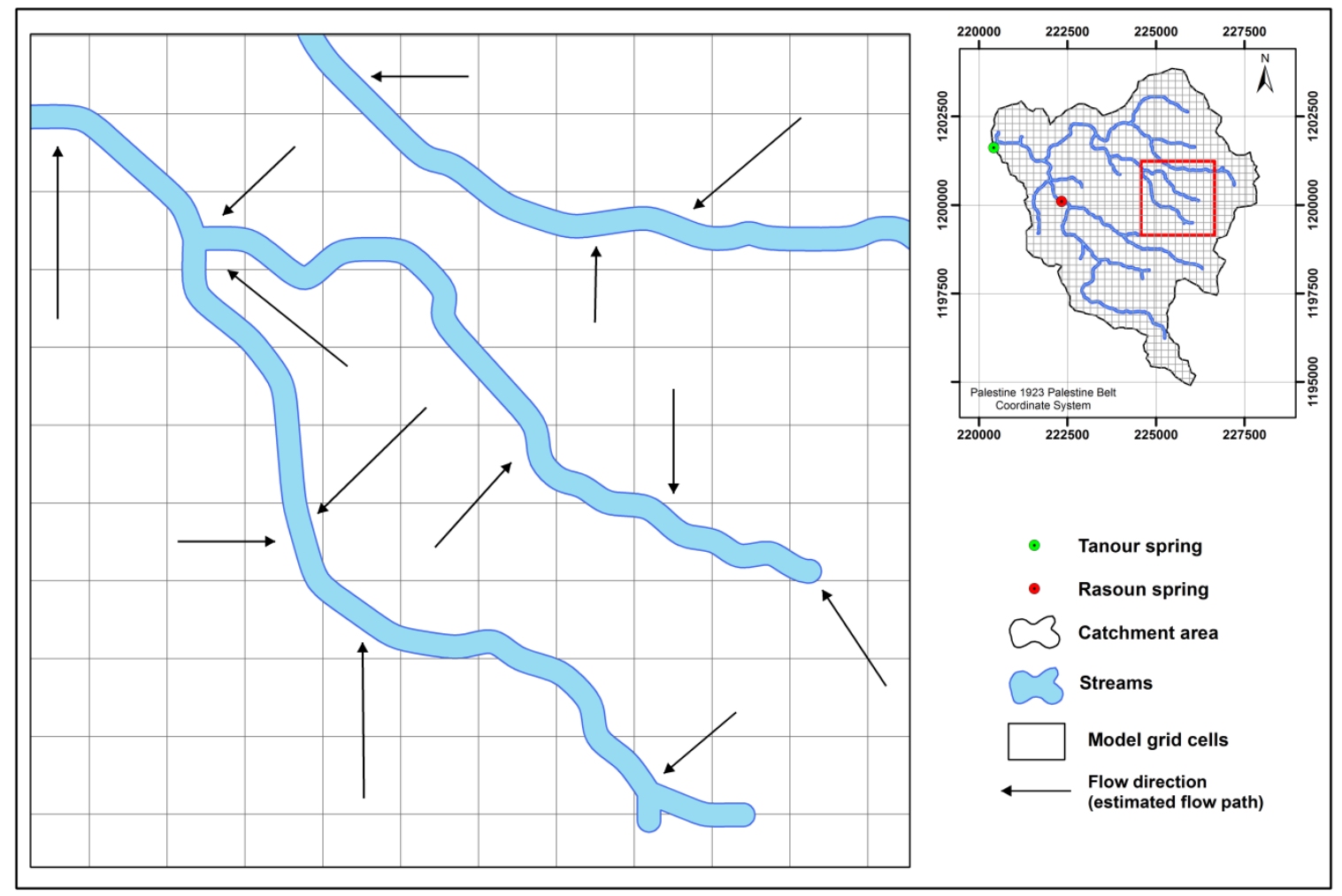

Figure 3-17: Example of conceptual water flow paths from different model cells within the catchment towards the nearest stream locations.

\subsubsection{Hydraulic conductivity estimation of the epikarst zone}

The base flow recession curve method (Rorabaugh 1964, Sauter 1992) which has been applied before in Section 2.8.2 was employed in order to estimate the transmissivity value of the epikarst zone, and then calculating the hydraulic conductivity value of the epikarst zone within the catchment area.

Although the Rorabaugh (1964) method theoretically provides information of the hydraulic characteristics of the phreatic (saturated) zone, it is believed that the late time response of the discharge variation in the spring is mainly controlled by the limiting lower hydraulic conductivity of the epikarst compartment rather than by the high conductivity of the conduit system. Based on the applied base flow recession curve method for the Tanour spring (see Section 2.8.2; Figure 2-27), the recession coefficient $(\alpha)$ for the epikarst zone was calculated at $0.0611 \mathrm{~d}^{-1}$. 


\subsubsection{Results}

Within the catchment area, the flow path length $\mathrm{s}[\mathrm{m}]$ from each grid pixel towards the nearest surface water stream as a final recharge location ranges between approximately 1 and $1700 \mathrm{~m}$ (Figure 3-18, a). The calculated hydraulic gradient $(\mathrm{dh} / \mathrm{dl})$ ranges between 0 and 0.8 (Figure $3-18$, b).

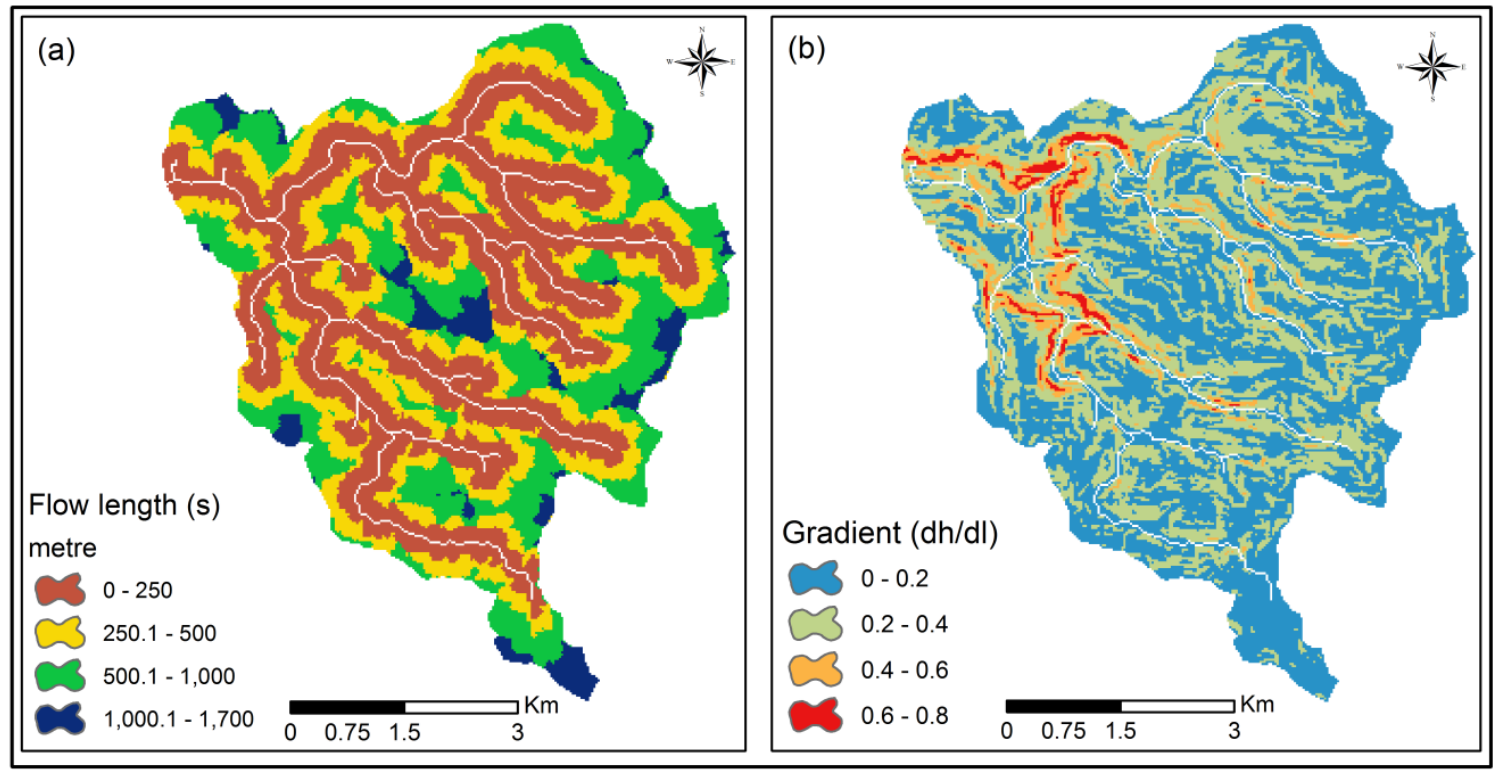

Figure 3-18: Shows: (a): flow length (s) from each pixel (model grid) in the catchment towards the streams, (b): gradient values ( $d h / d l)$.

Within the catchment area, $L$ was assumed to be $850 \mathrm{~m}$ (average flow length path towards the streams based on the flow length map), $S$ was assumed to be 0.02 (MWI 2000, Hobler et al. 2001), and the recession coefficient $\alpha$ for the epikarst zone was calculated to $0.0611 \mathrm{~d}^{-1}$ (see Figure 2-27). Based on the equation (2.1), Table 3-9 represents the calculated transmissivity and hydraulic conductivity values for the epikarst zone.

In order to calculate the hydraulic conductivity value from transmissivity values, an average saturated thickness of the epikarst zone is required. Due to the difficulty of estimating a spatially averaged and sound saturated thickness for the epikarst zone, three scenarios were assumed for the saturated epikarst thickness within the catchment area: (1) three meters, (2) five meters, and (3) seven meters. 
Table 3-9: Calculated hydraulic parameters for epikarst zone based on the base flow recession curve analysis for the Tanour spring.

\begin{tabular}{|c|c|c|c|c|c|}
\hline $\begin{array}{c}\text { Recession } \\
\text { coefficient } \\
\boldsymbol{\alpha}\left[\mathbf{d}^{-1}\right]\end{array}$ & $\begin{array}{c}\text { Storage } \\
\text { coefficient } \\
\boldsymbol{S}[-]\end{array}$ & $\begin{array}{c}\text { Average } \\
\text { distance to } \\
\text { water streams } \\
\boldsymbol{L}[\mathbf{m}]\end{array}$ & $\begin{array}{c}\text { Calculated } \\
\text { transmissivity } \\
\boldsymbol{T}\left[\mathbf{m}^{2} / \mathbf{d}\right]\end{array}$ & $\begin{array}{c}\text { Saturated } \\
\text { thickness } \\
{[\mathbf{m}]}\end{array}$ & $\begin{array}{c}\text { Calculated } \\
\text { hydraulic } \\
\text { conductivity } \boldsymbol{K} \\
{[\mathbf{m} / \mathbf{d}]}\end{array}$ \\
\hline \multirow{2}{*}{0.06113} & 0.02 & 850 & $3.58^{*} 10^{2}$ & 3 & 119 \\
\cline { 5 - 6 } & & & & 7 & 71 \\
\hline
\end{tabular}

Based on the three hydraulic conductivity ( $K$ ) values of the epikarst zone (see Table 3-9), maps were generated by calculating the average water flow velocity within the epikarst (Figure 3-19 a, b, and c). 


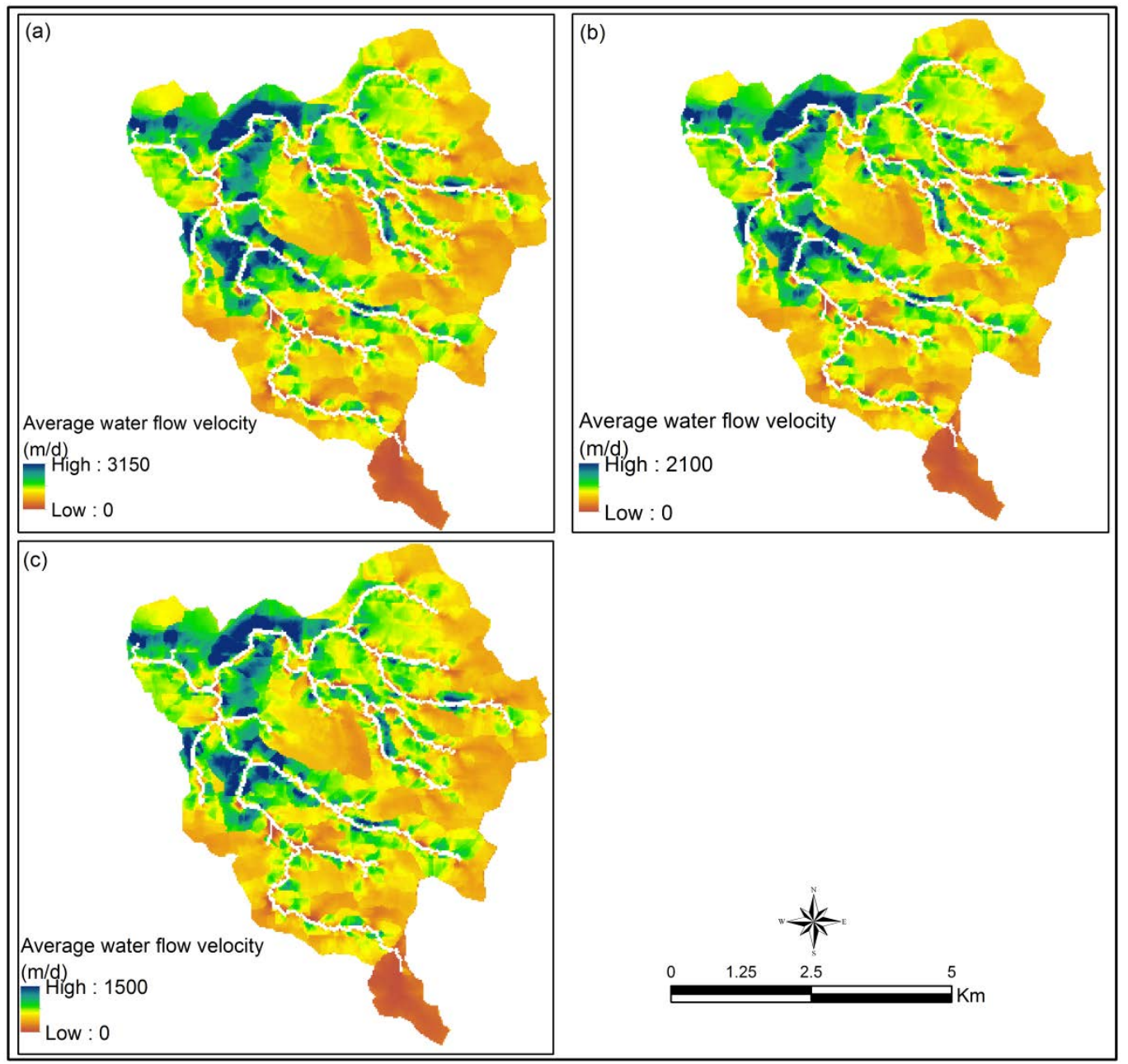

Figure 3-19: Calculated average flow velocity (va) within the epikarst zone based on the three scenarios for the calculated hydraulic conductivity values: (a) with hydraulic conductivity $K$ of $119 \mathrm{~m} / \mathrm{d}$, (b) hydraulic conductivity $K$ of $71 \mathrm{~m} / \mathrm{d}$, and (c) hydraulic conductivity $K$ of $51 \mathrm{~m} / \mathrm{d}$.

By applying Equation 3.7 using the flow path lengths (s) and the three scenarios for the average water flow velocity $\left(v_{a}\right)$, Figure 3-20 displays the calculated three scenarios for the water travel time within the epikarst zone towards the nearest streams. 


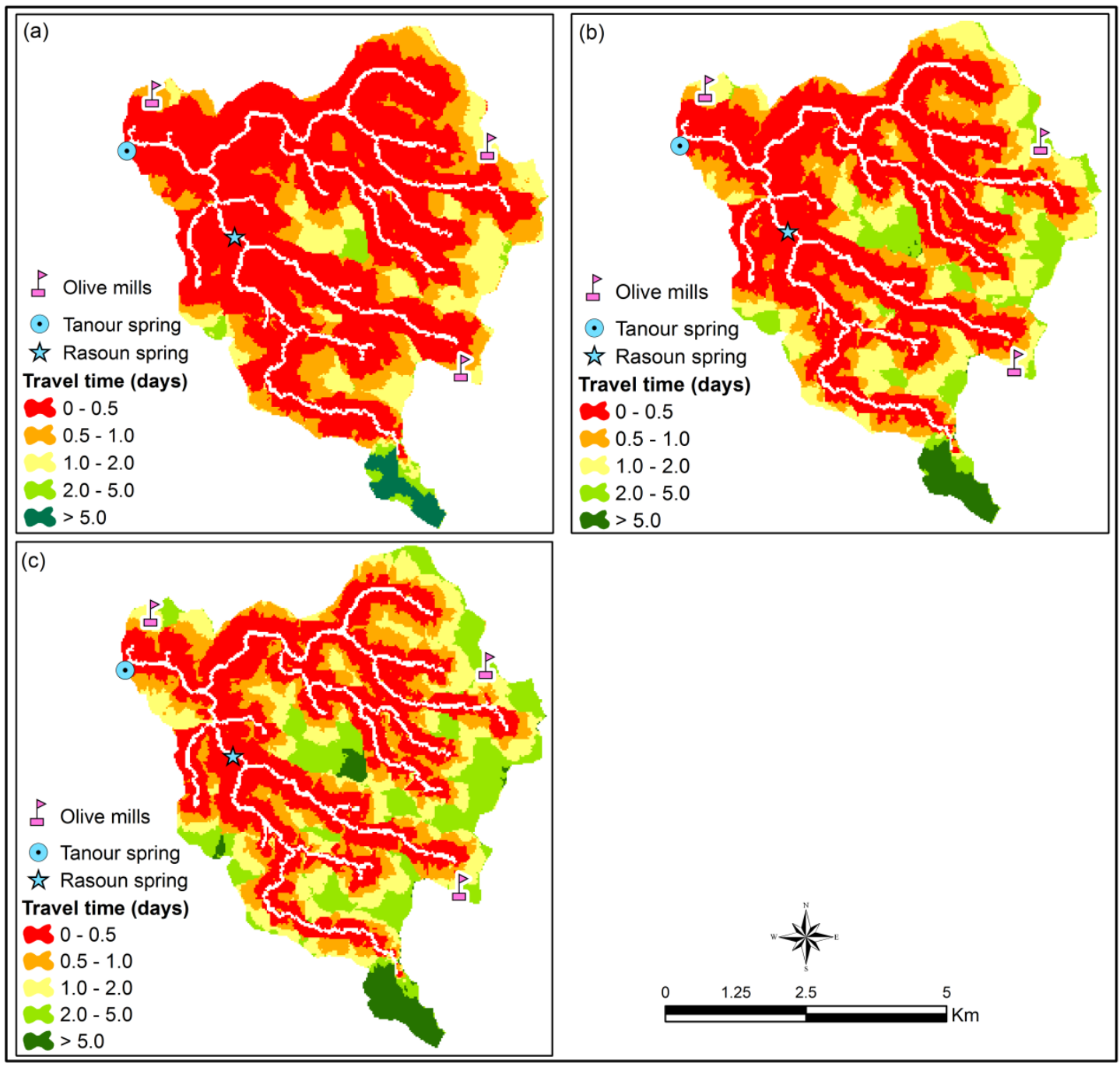

Figure 3-20: Calculated water travel time within the epikarst based on flow path lengths (s) towards the streams, and the three scenarios of the average water flow velocity (va).

\subsubsection{Discussion}

\subsubsection{Travel time physics-based method}

Applying the travel time physics-based model developed for the catchment area of Tanour and Rasoun spring to assess the travel time of the non-point pollution sources through the epikarst, following the land surface gradient, towards the streams as a final recharge point, it should be remembered that the chosen thickness of the epikarst zone is subject to uncertainty. According to (Goldscheider and Andreo 2007, Treek 2007, Williams 2008, Jones 2013), the thickness of the epikarst zone ranges from few centimetres to around $30 \mathrm{~m}$ or more. Based on the geological 
observations and field survey within the considered catchment area, three scenarios were assumed for the saturated thickness of the epikarst, three, five and seven metres.

Based on the three calculated scenarios for the water travel time, Table 3-10 represents the percentage of each water travel time class for each scenario. Based on the calculated percentages in Table 3-10, it can be recognized that most parts of the entire catchment area ( 97\%) show water travel time of up to 5 days.

Table 3-10: Calculated percentage of each water travel time range in each scenario.

\begin{tabular}{|c|c|c|c|}
\hline \multirow{2}{*}{$\begin{array}{c}\text { Water travel time } \\
\text { (in days) }\end{array}$} & \multicolumn{3}{|c|}{ Percentage (\%) } \\
\cline { 2 - 4 } & Scenario a & Scenario b & Scenario c \\
\hline $0-0.5$ & 65.7 & 50.0 & 40.1 \\
\hline $0.5-1$ & 18.2 & 20.9 & 20.9 \\
\hline $1-2$ & 12.0 & 17.7 & 19.2 \\
\hline $2-5$ & 2.1 & 8.7 & 16.1 \\
\hline$>5$ & 2.0 & 2.7 & 3.7 \\
\hline
\end{tabular}

From Table 3-10, it can be noticed that the change in hydraulic conductivity values affected mostly the water travel time range between 0.0 and 0.5 day with around $26 \%$ difference between scenario (a) and (c). In contrast, the percentage of the water travel time greater than 5 days is almost the same in the three scenarios.

By converting the travel time vulnerability map pixel values into a data file, travel time probability density functions (PDFs) based on the three scenarios of the epikarst hydraulic conductivity values can be obtained (Figure 3-21). High values of hydraulic conductivity cause high water flow velocity, and hence shorter water travel times within the epikarst. The very high pixel frequency and the sharp decrease of the PDF curves for short water travel times (between 1 and 5 day) is regarded to reflect the mainly short travel times through the epikarst of the Tanour and Rasoun karst system and therefore their high sensitivity to pollution. 


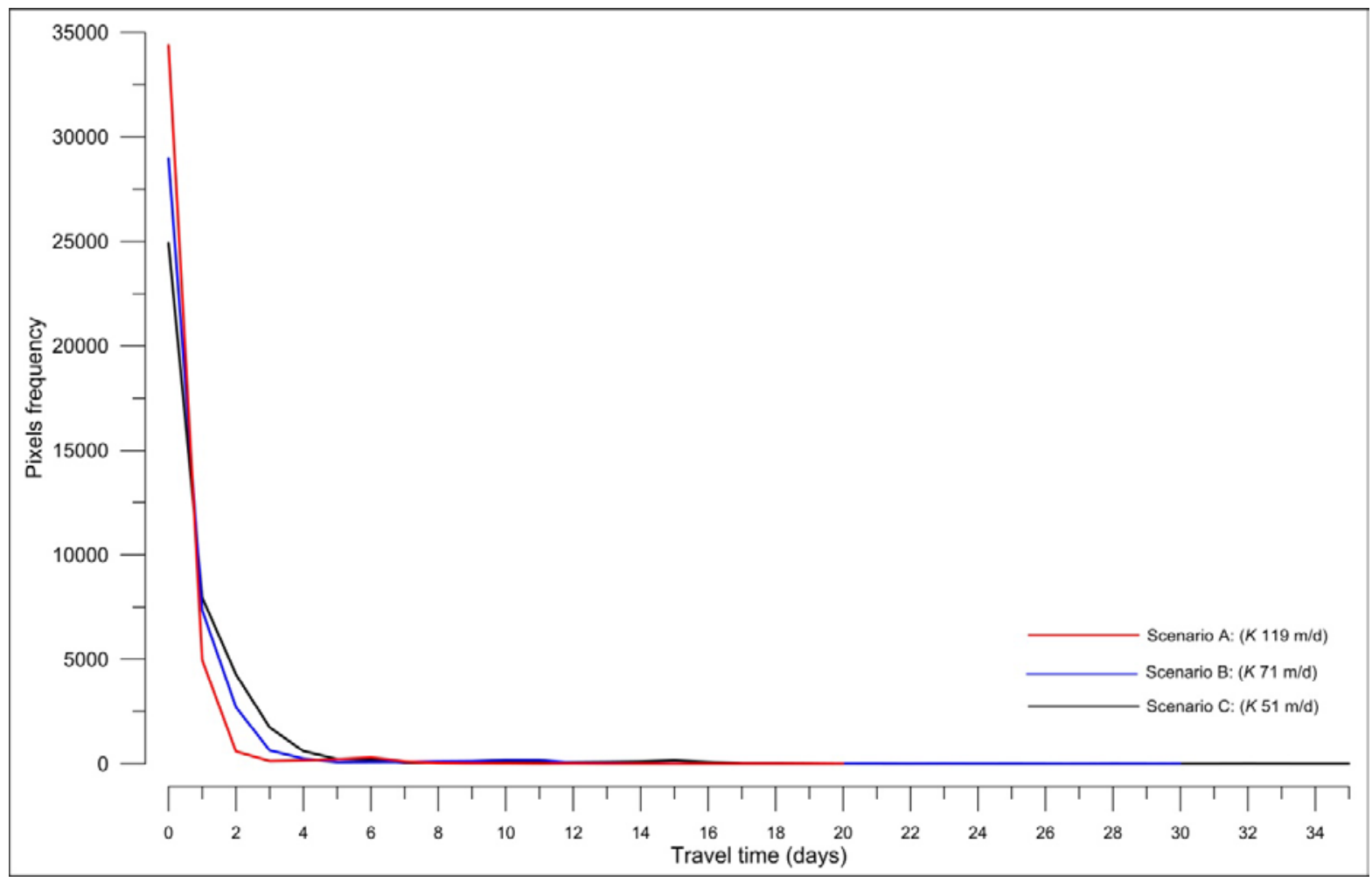

Figure 3-21: Probability density functions (PDF) of the calculated water travel time through the epikarst based on the three assumed scenarios of hydraulic conductivity of the epikarst zone.

According to Soulsby and Tetzlaff (2008), the land surface gradient (slope) was considered as a main parameter controlling the groundwater transport time within the epikarst. Figure 3-20 shows that the water travel time within most parts of the entire catchment area (within the three scenarios) was equal to or less than 5 days, except for a small area in the southeastern part, where water travel times are greater than 5 days. Within this area, the hydraulic gradient is relatively low (between 0 and 0.2; see Figure 3-18, b), and therefore the calculated average groundwater flow velocity is relatively low (see Figure 3-19), implying longer water travel times.

\subsubsection{Water travel times and potential sources of pollution within the catchment}

Pollution events represent the main water quality problem within the catchment area of the Tanour and Rasoun springs, due to the presence of two main pollution sources, the olive mills wastewater and discharge from septic tanks. Determining water travel times within a karst 
aquifer is a very important step providing information about aquifer vulnerability with respect to non-point source pollutants and their transport velocity towards the nearest stream as a final recharge location. Figure 3-20 shows that all of the three olive mills are located within the short travel time areas (less than 2 days). On the other hand, the illegal random dumping of wastewater from olive mills either in wadis, caves, or large conduits makes the prediction of the olive mills wastewater travel times very complicated.

The houses within the catchment area are still not connected to a sewage network. A spatial intersection analysis using ArcGIS was applied between the water travel time based map and the urban areas within the catchment (Table 3-11). Table 3-11 shows that around 94\% of the urban areas in scenario (a), and around 65\% of the urban areas in scenario (c) are located within areas with water travel times ranging between 0 and 2 days, compared to the very low percentage of the urban areas that are located in areas with travel times greater than 5 days (2.5\% to 5.7\%). This high percentage of urban areas located in areas with very fast water travel through the epikarst reflects the large contamination risk for the Tanour and Rasoun springs groundwater to septic tanks leakage.

Table 3-11: Intersection percentages between urban areas and the water travel time ranges in each scenario.

\begin{tabular}{|l|c|c|c|}
\hline \multirow{2}{*}{\multicolumn{1}{|c|}{ Intersection class }} & \multicolumn{3}{|c|}{ Percentage (\%) } \\
\cline { 2 - 4 } & Scenario a & Scenario b & Scenario c \\
\hline Urban - 0.0 to 0.5 day travel time & 44.0 & 26.7 & 19.8 \\
\hline Urban - 0.5 to 1.0 day travel time & 28.3 & 24.4 & 18.0 \\
\hline Urban - 1.0 to 2.0 days travel time & 21.6 & 29.4 & 27.7 \\
\hline Urban - 2.0 to 5.0 days travel time & 3.6 & 15.3 & 28.8 \\
\hline Urban - > 5 days travel time & 2.5 & 4.2 & 5.7 \\
\hline
\end{tabular}

\subsubsection{Travel time physics-based method in comparison with COP and EPK intrinsic vulnerability assessment method}

The travel time physics-based method is based mainly on the hydraulic characteristics of the karst aquifer system, compared to other intrinsic vulnerability assessment methods for karst aquifers which mainly consider other properties and parameters such as e.g. the geological setup, 
thickness of soil as a protective cover, precipitation, and karst features. A spatial intersection of the travel time physics-based method (scenario c) results and the COP and EPIK intrinsic vulnerability assessment methods (see Section 3.2.4.3) outcomes was applied. Table 3-12 represents the calculated percentage for each intersection class. Based on the results of the intersection between the travel time map and the COP vulnerability assessment map, around 58\% of the catchment are highly to moderately vulnerable areas with travel times up to 2 days. In contrast, the intersection between the travel time map and the EPIK vulnerability assessment map showed that around $80 \%$ of the catchment area are very highly and moderately vulnerable areas with water travel time up to 2 days. The high percentage of the very highly to moderately vulnerable areas with short water travel times reflects the high sensitivity of the catchment against pollution.

Table 3-12: Intersection percentages between travel time physics-based map (scenario c), and both the COP and EPIK intrinsic vulnerability assessment methods results.

\begin{tabular}{|l|l|l|l|l|l|l|}
\hline \multirow{2}{*}{$\begin{array}{c}\text { Travel time ranges } \\
\text { (scenario c) }\end{array}$} & \multicolumn{4}{|c|}{ COP } & \multicolumn{2}{c|}{ EPIK } \\
\cline { 2 - 7 } & High & Moderate & Low & Very low & Very High & Moderate \\
\hline 0.0 to 0.5 day & 20.8 & 9.3 & 6.2 & 4.0 & 21.5 & 19.0 \\
\hline 0.5 to 1.0 day & 8.5 & 7.0 & 3.7 & 1.9 & 8.6 & 12.4 \\
\hline 1.0 to 2.0 day & 5.3 & 7.6 & 5.2 & 1.0 & 5.5 & 13.6 \\
\hline 2.0 to 5.0 day & 3.0 & 8.0 & 4.5 & 0.3 & 3.1 & 12.6 \\
\hline$>5$ days & 0.1 & 2.8 & 0.6 & 0.2 & 0.1 & 3.6 \\
\hline
\end{tabular}

\subsection{Conclusions}

The application of the COP and EPIK intrinsic groundwater vulnerability assessment methods for the karst aquifer of the Tanour and Rasoun springs catchment area provide valuable information about the karst aquifer sensitivity to pollution, which can help decision makers for any future land and water use planning activity. All necessary property and parameter maps needed for the application of the COP and EPIK vulnerability assessment methods were obtained using ArcGIS software which is an efficient tool, especially with respect to the required raster calculations. 
The availability of a protective cover layer plays an important role in assessing aquifer vulnerability. Within the investigated catchment area, the protective cover above the highly karstified limestone is either absent or very thin, therefore a large proportion of the area can be classified as highly vulnerable. Based on the COP groundwater vulnerability assessment map, the catchment area was divided into four vulnerability classes (high, moderate, low, and very low), while based on the EPIK groundwater vulnerability assessment map, the catchment area was classified into two groups (very high and moderate). This difference in the vulnerability classes within the same catchment occurred because of using different parameters in each method and a different classification system. For example in the EPIK vulnerability assessment method, the very low vulnerability class is not available at all, and the low vulnerability class can appear only under specific conditions ( $\mathrm{F}>25$ with the presence of $\mathrm{P}_{4}+\left(\mathrm{I}_{3,4}\right)$ categories). The COP method showed a higher level of flexibility with respect to different hydrogeological conditions.

The high percentage of the very high to moderate vulnerable areas (either in COP or EPIK vulnerability assessment methods) reflects the urgent need to effectively protect the catchment area of the Tanour and Rasoun springs, by applying a good land use management and developing a water safety plan in the area. Also, frequent monitoring of water quality and monitoring of activities by the local olive mills and the related illegal dumping of wastewater in the wadis should be performed.

The travel time vulnerability assessment method represents a computerized spatially distributed approach using ArcGIS that calculates travel times of recharging water within the epikarst just below the land surface from each model grid cell within the catchment area towards surface water streams network as the final focused recharge location. This method is based on hydrogeological parameters of the aquifer such as hydraulic conductivity and effective porosity, as well as on the land surface gradient, the main factor affecting the direction of flow and transport velocity.

Using data with a higher degree of spatial resolution (especially with respect to the digital elevation model) may lead to more accurate and precise results related to the travel time as a final result. In comparison with other vulnerability assessment methods for karst aquifers, the travel time vulnerability assessment method is based on the hydraulic properties of the epikarstic 
zone above the karst aquifer rather than on actual karst features, karst networks, and soil thickness. The vulnerability classes of the EPIK and the COP method are not based on quantitative values and the individual classes "very highly, highly to moderately vulnerable areas" are very much subjected to the individual assessment method and not necessarily comparable among each other. Here, the travel time based method provides a new and quantitative approach that can be validated by independent measurements.

Determining water travel times provides relevant information for water resources management, allowing to understand and protect water resources in karst aquifers, especially in arid regions. The karst aquifer of the Tanour and Rasoun catchment area is considered as very sensitive to pollution events, where most parts of the catchment shows water travel times within the epikarst of up to 5 days.

Further intensive hydrogeological characterization of the karst aquifer within the Tanour and Rasoun springs catchment area is suggested. A focus should be directed at the assessment of the spatial variability of the saturated thickness of the epikarst and the hydraulic parameters. Conducting tracer tests could help in determining the karst aquifer properties and parameters relevant for groundwater transport more concisely. 


\subsection{References}

Abdelhamid G. (1993) Geological map of JARASH [map]. Ministry of Energy and Mineral Resources - Natural Resources Authority (geology directorate). National mapping project. Map sheet No. (3154-I); 1 sheet: 1:50.000. Amman, Jordan.

Abdelhamid G. (1995) The Geology of Jarash Area - Map Sheet (3154-I), Bulletin 30. Ministry of Energy and Mineral Resources - Natural Resources Authority (NRA) (Geology directorate). Amman, Jordan.

Aller L., Bennett T., Lehr J., Petty R., Hackett G. (1987) DRASTIC: A standardized system for evaluating ground water pollution potential using hydrogeologic setting. EPA (Environmental Protection Agency), USA. EPA/600/2-87/035.

Alwathaf Y., Mansouri B. (2011) Assessment of aquifer vulnerability based on GIS and ArcGIS methods: a case study of the Sana'a basin (Yemen). Journal of Water Resources and protection. 3:845-855; doi 10.4236/jwarp.2011.312094.

Brosig K., Geyer T., Subah A., Sauter M. (2008) Travel time based approach for the assessment of vulnerability of karst groundwater: the transit time method. Environ Geol. 54:905-911; doi: 10.1007/s00254-007-0898-0.

Brouyere S., Jeannin P.-Y., Dassargues A., Goldscheider N., Popescu I. C., Sauter M., Vadillo I., Zwahlen F. (2001) Evaluation and validation of vulnerability concepts using a physically based approach. Mémoire des Sciences et Techniques de l'Environnement, Volume 13, 7th conf. on Limestone Hydrology and Fissured Media. p 67-72.

Brouyere S. (2001) A quantitative point of view of the concept of vulnerability. In: Zwahlen F. (eds): COST action 620-Vulnerability and risk mapping for the protection of carbonate (karst) aquifers. Final report. p 10-15.

Buchanan B. P., Archibald J. A., Easton Z. M., Shaw S. B., Schneider R. L., Walter M. T. (2013) A phosphorus index that combines critical source areas and transport pathways using a travel time approach. Journal of Hydrology. 486:123-135; http://dx.doi.org/10.1016/j.jhydrol.2013.01.018. 
Butscher C., Huggenberger P. (2009) Modeling the temporal variability of karst groundwater vulnerability, with implication for climate change. Environmental Science and Technology. 43(6):1665-1669; doi 10.1021/es801613g.

Civita M. and De Maio M. (1997) SINTACS: Un systema parametrico per la valutazione e la cartografia della vulnerabilità degli acquiferi all'inquinamento (methodologia e automatizzazione). Pitagora Editrice, Bologna (cited in Kralik and Keimel 2003).

Daly D., Dassargues A., Drew D., Dunne S., Goldscheider N., Neale S., Popescu I. C., Zwahlen F. (2002) Main concepts of the "European approach" to karst-groundwatervulnerability assessment and mapping. Hydrogeology Journal. 10:340-345; doi 10.1007/s10040-001-0185-1.

Doerfliger N. and Zwahlen F. (1998) Practical guide-groundwater vulnerability mapping in karstic region (EPIK)-application to groundwater protection zone. Swiss agency for the environment. Forests and landscape (SAEFL), Bern.

Doerfliger N., Jeannin P.-Y., Zwahlen F. (1999) Water vulnerability assessment in karst environments: a new method of defining protection areas using a multi-attribute approach and GIS tools (EPIK method). Environmental Geology Journal. 39(2):165176.

Dosa M., Holko L., Kostka Z. (2011) Estimation of the mean transit times using isotopes and hydrograph recessions. Die Bodenkultur. 62(1-4):47-52.

Doummar J. (2012) Identification of indicator parameters for the quantitative assessment of vulnerability in karst aquifers. PhD dissertation. Georg-August-University of Göttingen, Germany.

Foster S. (1987) Fundamental concept in aquifer vulnerability, pollution risk and protection strategy, In: W. Van Dui- jvenbooden. and H. G. Van Waegeningh. (eds): Vulnerability of soil and groundwater to pollutions. Committee on hydrogeological research, Hague. p 69-86 (cited in Alwathaf and Mansouri 2011).

Foster S. and Hirata R. (1988) Groundwater pollution risk assessment-a methodology using available data. Pan American Center for Sanitary Engineering and Environmental Sciences (CEPIS). Lima, Peru. 
Goldscheider N., Klute M., Sturm S., Hötzl H. (2000) The PI method-a GIS-based approach to mapping groundwater vulnerability with special consideration of karst aquifers. Zeitschrift für Angewandte Geologie, 46(2000) 3:157-166. Hannover.

Goldscheider N. (2002) Hydrogeology and vulnerability of karst systems - examples from the northern Alps and the Swabian Alb. PhD dissertation. University of Karlsruhe, Germany.

Goldscheider N. (2003) The concept of groundwater vulnerability. In: Zwahlen F. (eds): COST action 620-vulnerability and risk mapping for the protection of carbonate (karst) aquifers. Final report, p 5-9.

Goldscheider N., Popescu I. C. (2003) The European approach. In: Zwahlen F. (eds): COST action 620-vulnerability and risk mapping for the protection of carbonate (karst) aquifers. Final report, p 17-21.

Goldscheider N., Andreo B. (2007) The geological and geomorphological framework. In: Goldscheider N., Drew D. (eds): Methods in karst hydrogeology. International association of hydrogeologists, IAH book series No. 26. Taylor and Francis group. London, UK. P. 9-27.

Hobler M., Margane A., Almomani M., Subah A. (2001) Groundwater Resources of northern Jordan, Vol.4 Contributions to the hydrogeology of northern Jordan. Federal Institute for Geosciences and Natural Resources (BGR) and Ministry of Water and Irrigation (MWI). Amman, Jordan.

Hölting B., Härtle' T., Hohberger K.-H., Nachtigall K. H., Villinger E., Weinzierl W., Wrobel J.-P. (1995) Konzept zur ermittlung der schutzfunktion der Grundwasserüberdeckung.Geol.Jb., C, 63, p. 5-24; Hannover (cited in Margane 2003).

Jeannin P.-Y., Cornaton F., Zwahlen F., Perrochet P. (2001) VULK: a tool for intrinsic vulnerability assessment and validation. 7th conference on limestone hydrology and fissured media, Besanc, on 20-22 September 2001. Sci Tech Environm Mem. 13:185188 (cited in Vias et al., 2006).

Jones W. (2013) Physical structure of the epikarst. Acta Carsologica 42/2-3: 311-314. 
Kavouri K., Plagnes V., Tremoulet J., Dörfliger N., Rejiba F., Marchet P. (2011) PaPRIKa: a method for estimating karst resource and source vulnerability- application to the Ouysse karst system (southwest France). Hydrogeology Journal. 19:339-353; doi 10.1007/s10040-010-0688-8.

Klimchouk A. (1997) The natural and principal characteristics of epikarst. 12th internat. congr. of Speleol. La Chaux-de-Fonds, Switzerlands, 10-17.8.1997, Proceed. Vol. 1 (cited in Golscheider 2000)

Kralik M., Keimel T. (2003) The time-input method. In: Zwahlen F. (eds): COST action 620vulnerability and risk mapping for the protection of carbonate (karst) aquifers. Final report, p 172-180.

Margane A. (2003) Guideline for groundwater vulnerability mapping and risk assessment for the susceptibility of groundwater resources to contamination. Technical cooperation project management. Protection and sustainable use of groundwater and soil resources in the Arab region between BGR and ACSAD. Volume 4. Damascus, Syria.

McGuire K., McDonnell J. (2006) A review and evaluation of catchment transit time modeling. Journal of Hydrology. 330:543-563; doi: 10.1016/j.jhydrol.2006.04.020.

Ministry of Agriculture (1994) National Soil Map and Land Use Project- The Soil of Jordan. Level 2: Semi detailed studies. Volume 2: Main Report. Hunting Technical Services in association with Soil Survey and Land Research Centre. Amman, Jordan.

MWI (Ministry of Water and Irrigation) (2000) Online hydrogeology of the Amman-Zarqa basin. Water resources policy support. Groundwater management component. Amman, Jordan.

MWI (Ministry of Water and Irrigation) (2013) Daily rainfall data for the time period between 1968/1969 and 2012/2013 (soft copy). Water information system, national master plan directorate. Amman, Jordan (unpublished).

MWI (Ministry of Water and Irrigation) - BGR (Federal Institute for Geosciences and Natural Resources) (2015) Automated online regular and continuous data measurement from Tanour spring for discharge values between April 2014 and September 2015 (soft copy). Jordan (unpublished). 
Popescu I. C., Gardin N., Brouyere S., Dassargues A. (2008) Groundwater vulnerability assessment using physically based modeling: from challenges to pragmatic solutions, ModelCARE'2007: Sixth Int. Conf on calibration and reliability in groundwater modeling, IAHS press. p 83-88, http://hdl.handle.net/2268/3595.

Rorabaugh M.I. (1964) Estimating changes in bank storage and ground-water contribution to streamflow. International Association of Scientific Hydrology. Publication 63:432-441.

Sauter M. (1992) Quantification and forecasting of regional groundwater flow and transport in a karstic aquifer (Gallusquelle, Malm, SW. Germany). PhD dissertation. Tübinger Geowissenschaftliche Arbeiten (TGA). 151 p.

Schilling K. E., Wolter C. F. (2007) A GIS-based groundwater travel time model to evaluate stream nitrate concentration reductions from land use change. Environ Geol. 53:433443; doi 10.1007/s00254-007-0659-0.

Sililo O.T.N., Saayman I.C., Fey, M.V. (2001) Groundwater vulnerability to pollution in urban catchments. Report to the Water Research Commission. WRC Project No. 1008/1/01. Water research commission, ISBN 1868457834. University of Cape Town, Pretoria.

Soulsby C., Tetzlaff D. (2008) Towards simple approaches for mean residence time estimation in ungauged basins using tracers and soil distributions. Journal of Hydrology. 363:60-74; doi: 10.1016/j.jhydrol.2008.10.001.

Treek B. (2007) How can the epikarst zone influence the karst aquifer hydraulic behaviour?. Environ Geol journal. 51:761-765; doi: 10.1007/s00254-006-0387-x.

Tripet J.-P., Doerflieger N., Zwahlen F., Delporte C. (2000) Vulnerability mapping in karst areas and its uses in Switzerland. Acta carsologica. 25(1):163-171.

Stempvoort V. D., Ewert L., Wassenaar L. (1993) Aquifer vulnerability index (AVI): A GIS compatible method for groundwater vulnerability mapping. Canadian Water Resources Journal. 18(1):25-37; doi 10.4296/cwrj1801025.

USGS Earth Explorer (2014a) Landsat-8 satellite image, Landsat scene identifier No. LC81740382014124LGN00. Accessed: June 2014. Available from: http://earthexplorer.usgs.gov. 
USGS Earth Explorer (2014b) ASTER digital elevation model 30 m resolution. Accessed: June 2014. Available from: http://earthexplorer.usgs.gov.

Vias J.M., Andreo B., Perles M.J., Carrasco F., Vadillo I., Jiménez P. (2002) Preliminary proposal of a method for vulnerability mapping in carbonate aquifers. In: Carrasco F., Durán J.J., Andreo B. (eds): Karst and Environment. p 75-83 (cited in Vias et al., 2003).

Vias J.M., Andreo B., Perles M.J., Carrasco F., Vadillo I., Jiménez, P. (2003) The COP method. In: Zwahlen F. (eds) COST action 620-vulnerability and risk mapping for the protection of carbonate (karst) aquifers. Final report, p 163-171.

Vias J., Andreo B., Perles M., Carrasco F., Vadillo I, Jimenez P. (2006) Proposed method for groundwater vulnerability mapping in carbonate (karstic) aquifers: The COP methodapplication in two pilot sites in southern Spain. Hydrogeology journal. 14(6):912-925; doi 10.1007/s10040-006-0023-6.

Vrba J., Zoporozec A. (eds) (1994) Guidebook on mapping groundwater vulnerability. International Contributions to Hydrogeology (IAH). 16, Hannover (cited in Goldscheider, 2003).

Williams P. (2008) The role of the epikarst in karst and cave hydrogeology: a review. International Journal of Speleology. 37(1):1-10.

Zwahlen F., Goldscheider N., Neale S. (2003) Introduction to vulnerability and risk mapping for the protection of carbonate (karst) aquifers. In: Zwahlen F., (eds): COST action 620-vulnerability and risk mapping for the protection of carbonate (karst) aquifers. Final report, p 1-5.

Zwahlen F. (eds) (2003) COST action 620-vulnerability and risk mapping for the protection of carbonate (karst) aquifers. Final report, 297 p. 


\section{Chapter four: Using stable isotopes of oxygen and hydrogen in determining groundwater travel time and springs response to precipitation events in karst aquifers.}

Related article to this chapter:

> Hamdan I., Wiegand B., Toll M., Sauter M., 2016. Spring response to precipitation events using $\delta^{18} \mathrm{O}$ and $\delta^{2} \mathrm{H}$ in the Tanour catchment, NW Jordan. Isotopes in Environmental and Health Studies. http://dx.doi.org/10.1080/10256016.2016.1159205. 


\subsection{Introduction}

The isotopes definition is representing the chemical element which have different number of neutrons, and the same number of protons. For example, both of oxygen and hydrogen have 3 different isotopes. Hydrogen isotopes are: ${ }^{1} \mathrm{H}$ (common hydrogen), ${ }^{2} \mathrm{H}$ (deuterium (heavy stable hydrogen)), and ${ }^{3} \mathrm{H}$ (tritium (radioactive isotope)). In contrast, oxygen isotopes are: ${ }^{16} \mathrm{O}$ (common oxygen), ${ }^{17} \mathrm{O}$ (heavy oxygen (very rare)), and ${ }^{18} \mathrm{O}$ (heavy oxygen). The isotopic composition of $\delta^{2} \mathrm{H}$ and $\delta^{18} \mathrm{O}$ is affected by different parameters such as temperature effect, amount effect (rain intensity), continental effect, seasonal effect, and altitude effect (Mazor 2004, Marshall et al. 2007).

According to Mazor (2004), the isotopic composition of water is determined normally in comparison with the ocean water isotopic composition. Craig (1961) defined a standard called "Standard Mean Ocean Water" (SMOW) for both of oxygen and hydrogen as a ratio of the heavy to light isotopes (e.g. ${ }^{2} \mathrm{H} /{ }^{1} \mathrm{H}$ ), and he defined the SMOW concentration as 1.050 for ${ }^{2} \mathrm{H} /{ }^{1} \mathrm{H}$ (SMOW) and 1.008 for ${ }^{18} \mathrm{O} /{ }^{16} \mathrm{O}$ (SMOW). The concentration of ${ }^{2} \mathrm{H} /{ }^{1} \mathrm{H}$ and ${ }^{18} \mathrm{O} /{ }^{16} \mathrm{O}$ in water is usually expressed as a unit in part per mil (\%), and it represent the deviation from the SMOW standard (Craig 1961, Sami 1992, Mazor 2004). This deviation are defined by Craig (1961) as $\delta^{2} \mathrm{H}$ or $\delta \mathrm{D}$ for ${ }^{2} \mathrm{H}$ (or deuterium) and $\delta^{18} \mathrm{O}$ for ${ }^{18} \mathrm{O}$, and calculated as follow (Mazor 2004):

$\delta^{2} \mathrm{H} \%=\left[\left(\left({ }^{2} \mathrm{H} /{ }^{1} \mathrm{H}\right)_{\text {sample }}-\left({ }^{2} \mathrm{H} /{ }^{1} \mathrm{H}\right)_{\text {SMOW }}\right) /\left({ }^{2} \mathrm{H} /{ }^{1} \mathrm{H}\right)_{\text {SMOW }}\right] * 1000$

$\delta^{18} \mathrm{O} \%=\left[\left(\left({ }^{18} \mathrm{O} /{ }^{16} \mathrm{O}\right)_{\text {sample }}-\left({ }^{18} \mathrm{O} /{ }^{16} \mathrm{O}\right)_{\text {SMOW }}\right) /\left({ }^{18} \mathrm{O} /{ }^{16} \mathrm{O}\right)_{\text {SMOW }}\right] * 1000$

Positive values of $\delta^{2} \mathrm{H}$ or $\delta^{18} \mathrm{O}$ means water with more ${ }^{2} \mathrm{H}$ or ${ }^{18} \mathrm{O}$ than SMOW, and thus are called "enriched" or "heavy". In contrast, negative $\delta^{2} \mathrm{H}$ or $\delta^{18} \mathrm{O}$ values means water with less ${ }^{2} \mathrm{H}$ or ${ }^{18} \mathrm{O}$ than SMOW and thus are called "depleted" or "light" (Mazor 2004, Khayat 2005).

The isotopic composition of oxygen and hydrogen in natural water (precipitation and groundwater) provides important information to study the origin of water as a function of geohydrological and meteorological factors such as the source of water vapor and climate change (Dansgaard 1964, Gat and Carmi 1970; 1987, Gat 1996, Bajjali 2012, Al-Ameri et al. 2014), processes involved in groundwater recharge (Salameh 2004, Bajjali 2006), and water residence and travel times in aquifer systems (Morales et al. 2007, Ettayfi et al. 2012). 
For the eastern Mediterranean region including Jordan, several studies were conducted using $\delta^{18} \mathrm{O}$ and $\delta^{2} \mathrm{H}$ to determine the origin of water vapor in precipitation, the source of groundwater recharge, and water travel and residence times (e.g. Gat 1972, Bajjali and Abu-Jaber 2001, Salameh 2004, Khayat 2005, Saad et al. 2005, Bajjali 2006; 2012). Gat and Dansgaard (1972) established the Mediterranean Meteoric Water Line (MMWL) $\left(\delta^{2} \mathrm{H}=8^{*} \delta^{18} \mathrm{O}+22 \%\right.$ as a modification from the Global Meteoric Water Line (GMWL) $\left(\delta^{2} \mathrm{H}=8^{*} \delta^{18} \mathrm{O}+10 \%\right.$; Craig 1961) based on the shift in d-excess values observed in the eastern Mediterranean areas. Saad et al. (2005) analyzed rainwater in coastal and high land areas in Lebanon and calculated a Local Meteoric Water Line (LMWL) to $\delta^{2} \mathrm{H}=7.13 * \delta^{18} \mathrm{O}+15.98$ \%o. For the Jericho area/Palestine, Khayat (2005) determined a LMWL of $\delta^{2} \mathrm{H}=8.10 * \delta^{18} \mathrm{O}+19.50 \%$ \%. In Jordan, Bajjali (2012) studied the chemical and isotopic composition of precipitation in the context of climate change. For this study, rainwater was collected at Ras Munif rain gauge station (AH0003), and an average value for $\delta^{18} \mathrm{O}$ of $-6.86 \%$ and for $\delta^{2} \mathrm{H}$ of $-30.38 \%$ was observed. The LMWL for entire Jordan was calculated by Bajjali (2012) to $\delta^{2} \mathrm{H}=6.27 * \delta^{18} \mathrm{O}+11.40 \%$ osing unpublished sources from the International Atomic Energy Agency- IAEA. Data include four stations for the time period between 1965 and 1969, and 11 stations for 1987 to 1989 (Bajjali 1990; 1994, Bajjali et al. 1997). In addition, data from the monitoring program of the Water Authority of Jordan, collected between 1990 and 2005, were included.

For the Yarmouk catchment area in Jordan (located North of the Tanour catchment area), Salameh (2004) used environmental isotopes to study recharge-discharge mechanisms. The isotopic composition of $\delta^{18} \mathrm{O}$ and $\delta^{2} \mathrm{H}$ was analyzed in precipitation during the year 2002 (WAJ 2002). Deir Alla rain gauge station (Jordan Valley) receives $250 \mathrm{~mm}$ rainfall per year; the highlands (Irbid and Ras Munif rain gauge station) are characterized by rainfall amounts of 470 and $660 \mathrm{~mm} / \mathrm{yr}$, respectively. Average $\delta^{18} \mathrm{O}$ values from Irbid (600 m above sea level) and Ras Munif rain gauge stations (1150 m above sea level) were -7.02 \%o and -7.26 \%o, while $\delta^{2} \mathrm{H}$ values were -33.28 \%o and -33.20 \%o, respectively. For Jordan Valley (Deir Alla rain gauge station; -235 $\mathrm{m}$ below sea level), an average $\delta^{18} \mathrm{O}$ value of $-4.06 \%$ and $\delta^{2} \mathrm{H}$ value of $-14.50 \%$ was reported.

Direct changes in the isotopic composition of $\delta^{18} \mathrm{O}$ and $\delta^{2} \mathrm{H}$ are believed to reflect fast water movement within the karst features like caves and large conduits in the catchment area. Butscher and Huggenberger (2009) and Lakey and Krothe (1996) suggested that rapid changes in the composition of $\delta^{18} \mathrm{O}$ and $\delta^{2} \mathrm{H}$ of karst spring water to rainfall events can be attributed to water 109 
movement through the epikarst, conduits, and diffuse storage, which are generally characterized by fast water travel times, low storage capacity, and short residence time within the karst aquifer. This chapter reports the $\delta^{18} \mathrm{O}$ and $\delta^{2} \mathrm{H}$ values of precipitation and spring discharge from Tanour and Rasoun springs. The study is focused on the characterization of $\delta^{18} \mathrm{O}$ and $\delta^{2} \mathrm{H}$ in rainfall and snow in the Tanour and Rasoun catchment area and the investigation of spring response to rainfall and snowmelt events using stable isotopes of oxygen and hydrogen. In addition, spring water temperature, spring discharge, electrical conductivity and turbidity data were used as additional parameters to obtain further information about the recharge processes in the catchment.

\subsection{Sampling and methodology}

Forty-one rain and snow water samples were collected from five different locations within the catchment area during the winter seasons 2013/2014 and 2014/2015 (Figure 4-1).

Elevations of the sampling locations range from $733 \mathrm{~m}$ to $1115 \mathrm{~m}$ above sea level (Table 4-1). The rainwater and snow samples were collected event by event from each location by filling the

bottle directly from the falling rain. Snow samples were filled directly in a bottle. Then the bottle was closed tight and the snow was left to melt inside the bottle. 


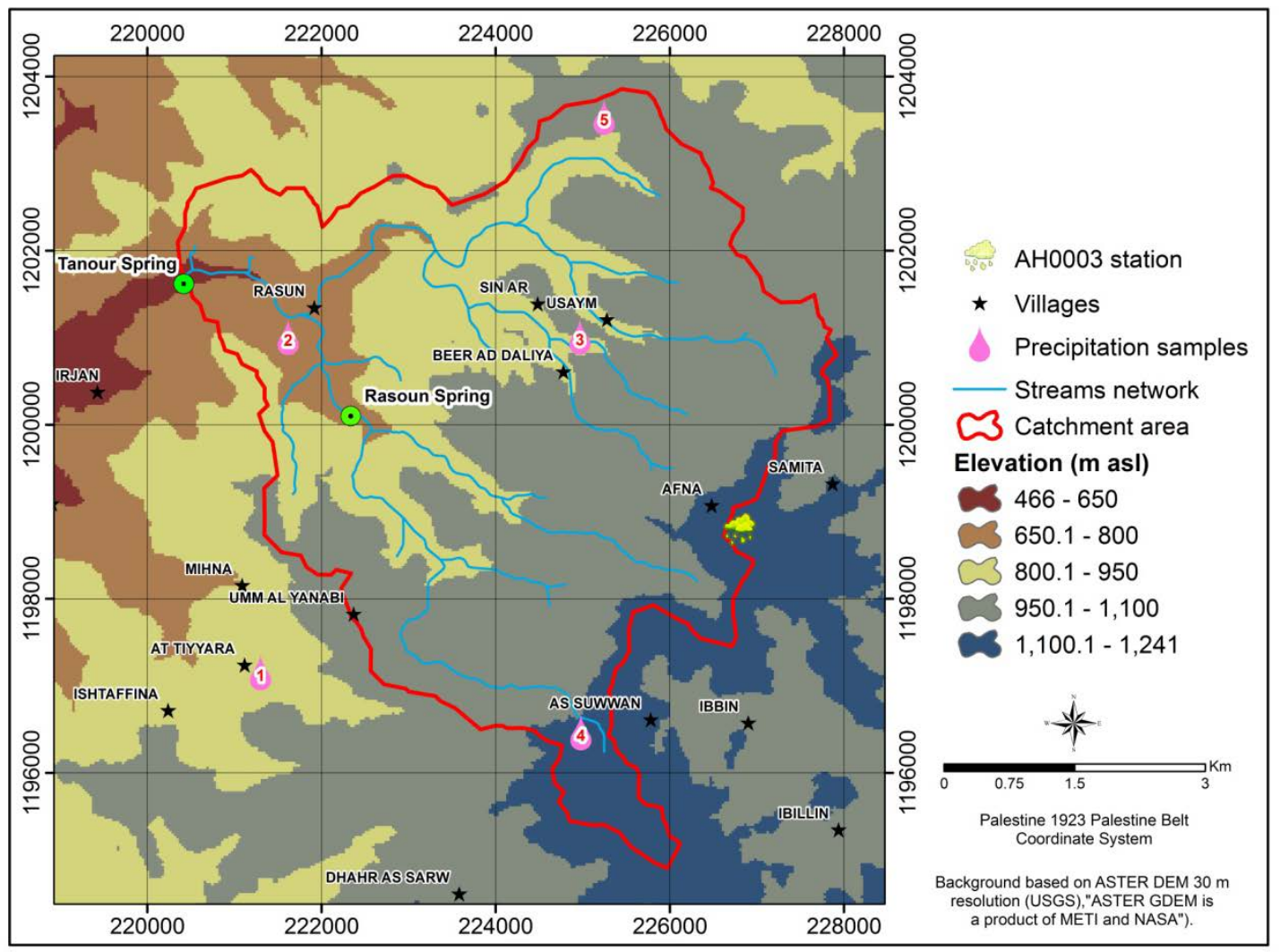

Figure 4-1: Locations of rain and snow samples collection, and Ras Munif meteorological station (AH0003) (modified after Hamdan et al. 2016).

Table 4-1: Information on rainwater and snow collection sites.

\begin{tabular}{|c|c|c|c|c|}
\hline \multirow{2}{*}{ Location number } & \multicolumn{4}{|c|}{ Coordinates (Palestine 1923 Palestine Belt) } \\
\cline { 2 - 5 } & East & North & Altitude (m) & Number of samples \\
\hline 1 & 221303 & 1197162 & 867 & 10 \\
\hline 2 & 221613 & 1201003 & 733 & 6 \\
\hline 3 & 224979 & 1200995 & 966 & 6 \\
\hline 4 & 224978 & 1196479 & 1115 & 15 \\
\hline 5 & 225243 & 1203520 & 999 & 4 \\
\hline
\end{tabular}

In addition, 105 and 112 groundwater samples were collected from Tanour and Rasoun springs, respectively, between November 2014 and March 2015. The water samples were collected in 30 $\mathrm{ml}$ glass bottles and stored in a refrigerator prior to analysis of environmental isotopes $\delta^{2} \mathrm{H}$ and $\delta^{18} \mathrm{O} . \delta^{18} \mathrm{O}$ and $\delta^{2} \mathrm{H}$ values (in per mil \%o) were analyzed using a Liquid Water Isotope Analyzer 
(LGR, IWA-35-EP) (Figure 4-2) and V-SMOW (Vienna Standard Mean Ocean Water) as reference standard at the Geosciences Center, Georg-August-University of Göttingen, Germany. The average precision of the measurements for the precipitation samples are $0.06 \%$ for $\delta^{18} \mathrm{O}$, and $0.33 \%$ for $\delta^{2} \mathrm{H}$, while in Tanour and Rasoun springs are $0.05 \%$ and $0.12 \%$ for $\delta^{18} \mathrm{O}$, and $0.29 \%$ and $0.87 \%$ for $\delta^{2} \mathrm{H}$, respectively. In addition, three LGR working standards were used during isotopic analysis for quality control. The certified standards range between $-2.80 \%$ and $19.50 \%$ for $\delta^{18} \mathrm{O}$ and from $-9.5 \%$ to $-154.3 \%$ for $\delta^{2} \mathrm{H}$.

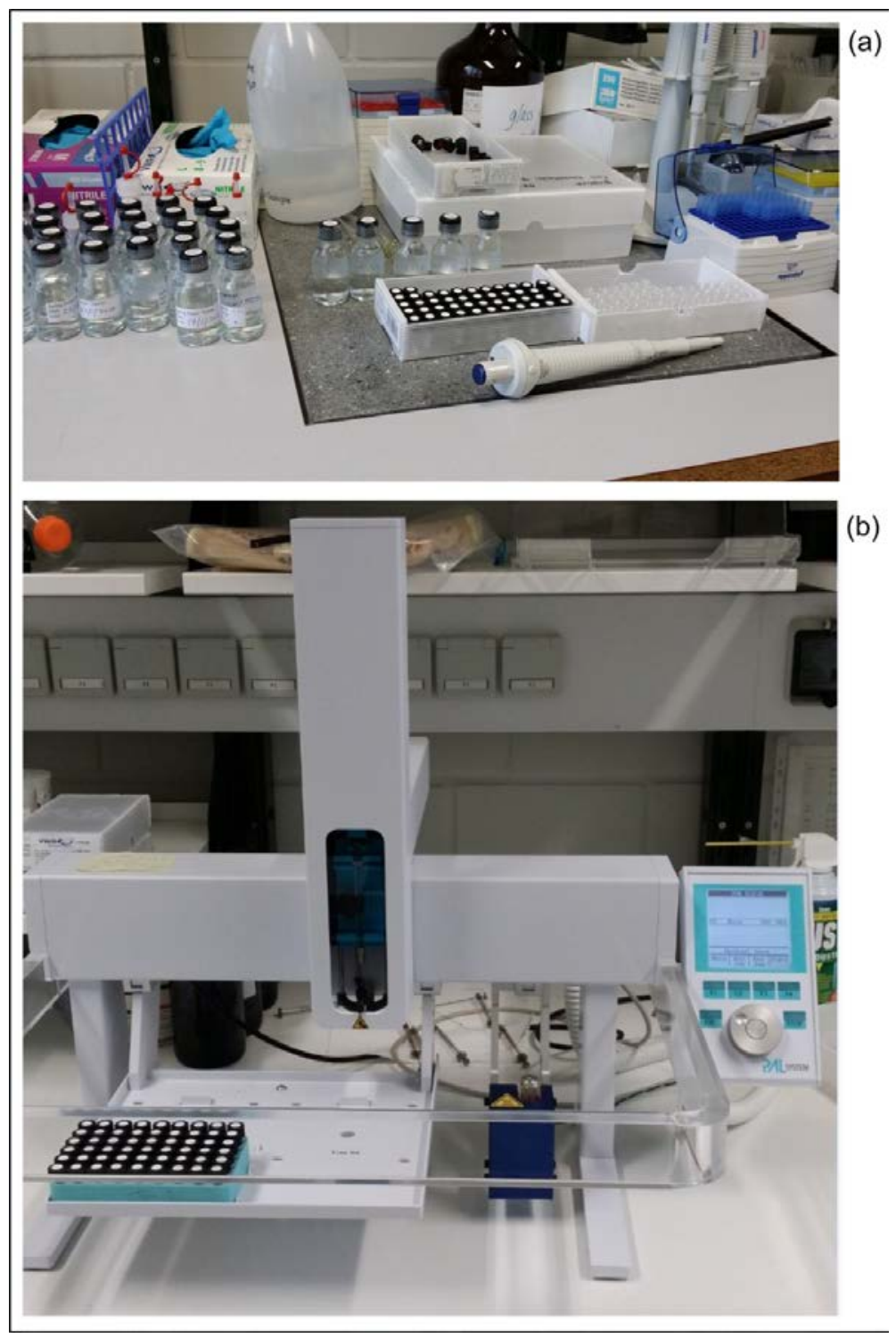

Figure 4-2: Shows (a) samples preparation for analysis, and (b) Liquid Water Isotope Analyzer (LGR, IWA-35-EP) for analyzing $\delta^{18} O$ and $\delta^{2} H$ (photo source: Ibraheem Hamdan). 
Water temperature $\left({ }^{\circ} \mathrm{C}\right)$, spring discharge $\left(\mathrm{m}^{3} / \mathrm{h}\right)$, and turbidity values (NTU) were monitored by a SEBA multi-parameter probe, type MPS-D8 at Tanour spring. Spring discharge $\left(\mathrm{m}^{3} / \mathrm{h}\right)$ is not corrected for water withdrawal by pumping. On the other hand, In-situ TROLL 9500 multiparameter probe was installed in Rasoun spring for monitoring water temperature $\left({ }^{\circ} \mathrm{C}\right)$, electrical conductivity ( $\mu \mathrm{S} / \mathrm{cm})$, and turbidity values (NTU). Air temperature, and daily rainfall data were obtained from Ras Munif meteorological station (AH0003) (MWI 2015).

\subsection{Results and discussion}

\subsection{1. $\delta^{18} \mathrm{O}$ and $\delta^{2} \mathrm{H}$ composition of rain and snow water samples}

$\delta^{18} \mathrm{O}$ and $\delta^{2} \mathrm{H}$ values of rain and snow water samples vary from -3.26 \%о to -17.34 \%o (average value: $-7.84 \pm 3.23 \%$ ) and from $-4.44 \%$ to $-110.43 \%$ (average value: $-35.67 \pm 25.04 \%$ ), respectively. Deuterium excess (d-excess) values calculated for each sampling site (d-excess= $\delta^{2} \mathrm{H}-8^{*} \delta^{18} \mathrm{O}$; Dansgaard 1964) range from $17.77 \%$ o to 34.06 \%o (average value: $27.09 \pm 4.03 \%$ ). $\delta^{18} \mathrm{O}$ and $\delta^{2} \mathrm{H}$ composition of rainwater and snow samples are presented in Table 4-2.

The Local Meteoric Water Line (LMWL) for the study area based on $\delta^{18} \mathrm{O}$ and $\delta^{2} \mathrm{H}$ values of the rainwater and snow samples is defined by the equation $\delta^{2} \mathrm{H}=7.66 * \delta^{18} \mathrm{O}+24.43 \%$ o $\left(\mathrm{R}^{2}=0.98\right)$. Figure 4-3 shows the LMWL for the study area in comparison with the GMWL and the MMWL; the LMWL is located close to the Mediterranean Meteoric Water Line (MMWL).

The isotopic composition of $\delta^{18} \mathrm{O}$ and $\delta^{2} \mathrm{H}$ analyzed for precipitation in the present study is in good agreement with previous results from Jordan. E.g., Salameh (2004) reported average $\delta^{18} \mathrm{O}$ and $\delta^{2} \mathrm{H}$ values of $-7.02 \%$ and $-33.28 \%$, and $-7.26 \%$ and,-33.20 \%, for Irbid and Ras Munif rain gauge stations, respectively, for the year 2002. In addition, Bajjali (2012) reported average values for 66 rainwater samples collected at Ras Munif rain gauge station for different years $\left(\delta^{18} \mathrm{O}=-6.86 \%\right.$ and $\delta^{2} \mathrm{H}=-30.38 \%$, and a calculated d-excess value of $24.50 \%$ \%). 
Table 4-2: $\delta^{18} O$ and $\delta^{2} H$ composition of rain and snow water samples collected during the winter seasons 2013/2014 and 2014/2015.

\begin{tabular}{|c|c|c|c|c||c|c|c|c|c|}
\hline $\begin{array}{c}\text { Location } \\
\text { ID. }\end{array}$ & Date & $\begin{array}{c}\boldsymbol{\delta}^{\mathbf{1 8}} \mathbf{O} \\
\mathbf{\%}\end{array}$ & $\boldsymbol{\delta}^{\mathbf{2}} \mathbf{H} \mathbf{\%}$ & $\begin{array}{c}\mathbf{d}- \\
\text { excess }\end{array}$ & $\begin{array}{c}\text { Location } \\
\text { ID. }\end{array}$ & Date & $\begin{array}{c}\boldsymbol{\delta}^{\mathbf{1 8}} \mathbf{O} \\
\mathbf{\% o}\end{array}$ & $\boldsymbol{\delta}^{\mathbf{2}} \mathbf{H}$ \%o & $\begin{array}{c}\mathbf{d}- \\
\text { excess }\end{array}$ \\
\hline 1 & 11.12 .2013 & -9.33 & -48.74 & 25.92 & 3 & 14.02 .20 & -8.02 & -39.29 & 24.89 \\
\hline 1 & 13.12 .2013 & -17.34 & -110.43 & 28.26 & 4 & 11.12 .20 & -9.80 & -52.15 & 26.27 \\
\hline 1 & 14.12 .2014 & -5.58 & -21.41 & 23.21 & 4 & 13.12 .20 & -15.22 & -92.18 & 29.58 \\
\hline 1 & 22.12 .2014 & -3.26 & -7.35 & 18.76 & 4 & 14.12 .20 & -4.81 & -20.72 & 17.77 \\
\hline 1 & 03.01 .2015 & -4.77 & -9.02 & 29.13 & 4 & 21.12 .20 & -4.71 & -11.30 & 26.41 \\
\hline 1 & 05.01 .2015 & -5.87 & -19.02 & 27.91 & 4 & 03.01 .20 & -6.26 & -19.38 & 30.68 \\
\hline 1 & 10.01 .2015 & -9.34 & -49.34 & 25.40 & 4 & 04.01 .20 & -6.04 & -19.14 & 29.18 \\
\hline 1 & 17.01 .2015 & -5.83 & -24.87 & 21.77 & 4 & 04.01 .20 & -6.54 & -19.34 & 32.97 \\
\hline 1 & 12.02 .2015 & -7.57 & -37.56 & 22.97 & 4 & 05.01 .20 & -6.53 & -21.42 & 30.80 \\
\hline 1 & 18.02 .2015 & -5.44 & -18.03 & 25.49 & 4 & 11.02 .20 & -6.62 & -32.64 & 20.31 \\
\hline 2 & 11.12 .2013 & -9.09 & -44.80 & 27.89 & 4 & 13.02 .20 & -9.12 & -42.84 & 30.16 \\
\hline 2 & 13.12 .2013 & -15.38 & -95.25 & 27.78 & 4 & 15.02 .20 & -10.40 & -62.43 & 20.76 \\
\hline 2 & 14.12 .2014 & -8.64 & -47.35 & 21.79 & 4 & 16.02 .20 & -6.65 & -22.83 & 30.39 \\
\hline 2 & 09.01 .2015 & -10.13 & -48.15 & 32.91 & 4 & 18.02 .20 & -6.67 & -23.62 & 29.75 \\
\hline 2 & 10.01 .2015 & -8.61 & -34.84 & 34.06 & 4 & 19.02 .20 & -9.41 & -45.02 & 30.26 \\
\hline 2 & 18.02 .2015 & -4.66 & -12.97 & 24.27 & 4 & 21.02 .20 & -8.48 & -38.69 & 29.16 \\
\hline 3 & 11.12 .2013 & -7.56 & -29.33 & 31.16 & 5 & 13.12 .20 & -12.51 & -73.68 & 26.40 \\
\hline 3 & 13.12 .2013 & -13.21 & -72.36 & 33.32 & 5 & 04.01 .20 & -3.91 & -4.63 & 26.62 \\
\hline 3 & 03.01 .2015 & -5.67 & -13.50 & 31.84 & 5 & 05.01 .20 & -3.71 & -4.44 & 25.25 \\
\hline 3 & 04.01 .2015 & -5.88 & -18.11 & 28.94 & 5 & 17.02 .20 & -7.28 & -32.78 & 25.49 \\
\hline 3 & 16.01 .2015 & -5.76 & -21.37 & 24.74 & & & & & \\
\hline & & & & & & &
\end{tabular}

Previous results from the IAEA/WMO (World Meteorological Organization) database (IAEA/WMO July 2015) show also a good agreement with the data of this study. Forty-seven rainwater samples (Annex 2) collected at Ras Munif rain gauge station between 1987 and 2004 (monthly cumulative rainwater samples) showed $\delta^{18} \mathrm{O}$ and $\delta^{2} \mathrm{H}$ values of $-4.75 \%$ to $-8.19 \%$ (average: $-6.69 \pm 0.87 \%$ ) and $-14.30 \%$ to $-42.35 \%$ (average: $-29.79 \pm 7.63 \%$ ), respectively. Deuterium excess values calculated for the data ranged between 17.80 \%o and 31.33 \%o (average: $23.74 \pm 2.93 \%$ \%). The LMWL for Ras Munif rain gauge station is defined by the equation $\delta^{2} \mathrm{H}=8.08 * \delta^{18} \mathrm{O}+24.31 \%\left(\mathrm{R}^{2}=0.85\right)$ and thus consistent with the results of the present investigation. 


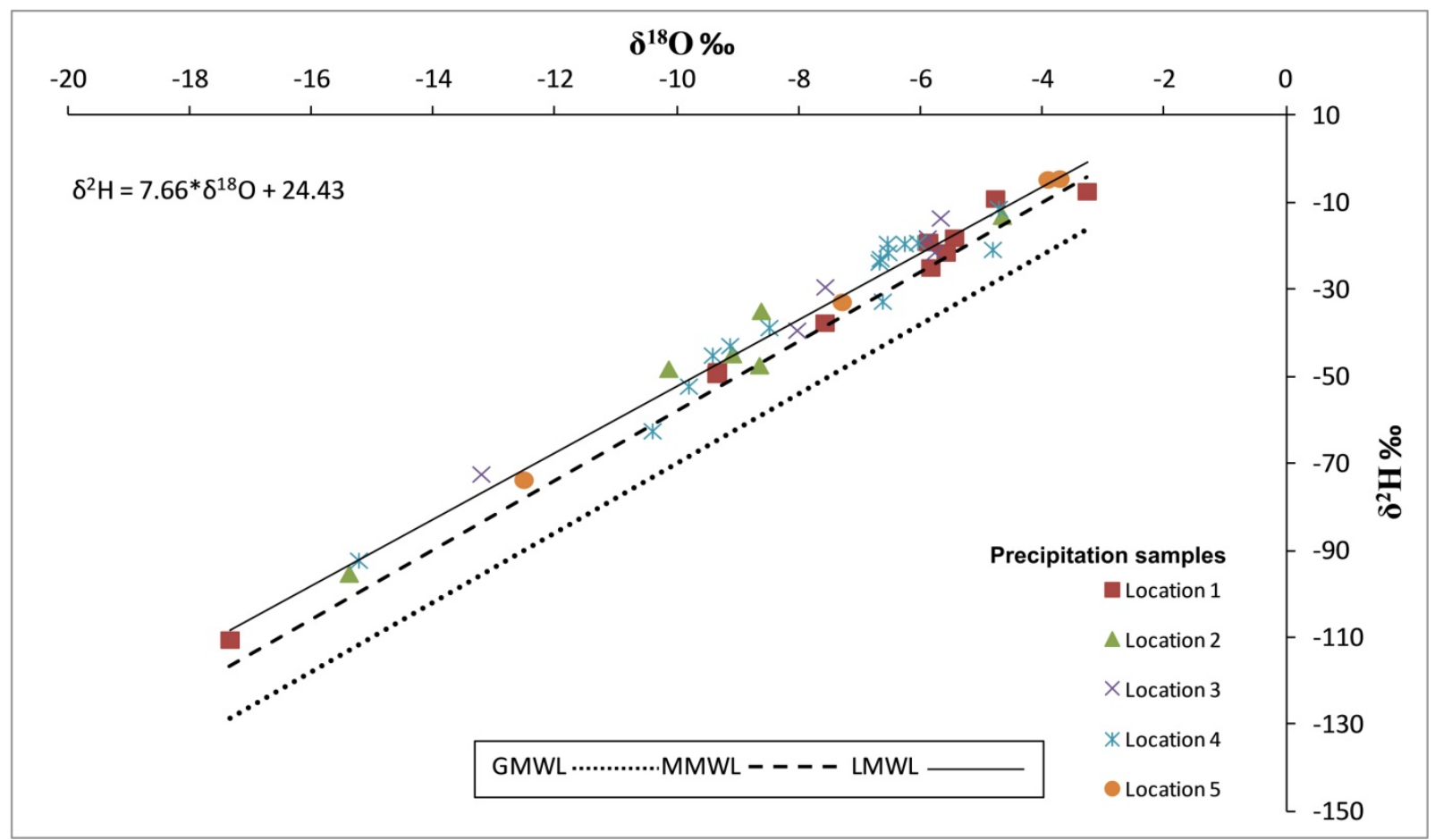

Figure 4-3: Local Meteoric Water Line (LMWL) for the study area based on rainfall and snow samples collected from catchment in comparison to the Global Meteoric Water Line (GMWL) and the Mediterranean Meteoric Water Line (MMWL) (modified after Hamdan et al. 2016).

The isotopic composition of $\delta^{18} \mathrm{O}$ and $\delta^{2} \mathrm{H}$ is affected by different factors like altitude, temperature, rainfall amount, and humidity. The high d-excess value of $24.43 \%$ and the slope of 7.66 indicate that precipitation in the study area is not significantly affected by evaporation processes. Previous studies by Dansgaard (1964) confirm that d-excess values of $>15 \%$ are characteristic for precipitation in the Eastern Mediterranean area. Generally, cold and dry continental air masses originating from the European continent that pass the warm Mediterranean Sea produce higher d-excess values due to rapid evaporation and large scale convergence (Rindsberger et al. 1983, Saad et al. 2005, Bajjali 2012).

\subsubsection{Tanour spring response to precipitation events using $\delta^{18} O$ and $\delta^{2} H$}

For the sampling period between December 2014 and March 2015, $\delta^{18} \mathrm{O}$ values of Tanour spring water range from $-6.29 \%$ to $-7.17 \%$ with an average value of $-6.58 \pm 0.19 \%$. $\delta^{2} \mathrm{H}$ values of the 
same samples range from $-28.84 \%$ to $-32.69 \%$ with an average value of $-30.46 \pm 1.03 \%$. All stable isotope $\left(\delta^{18} \mathrm{O}\right.$ and $\left.\delta^{2} \mathrm{H}\right)$ results for Tanour spring are presented in (Table 4-3).

The variation in $\delta^{18} \mathrm{O}$ and $\delta^{2} \mathrm{H}$ composition versus time may be used as an indicator for water travel times and spring response to recharge processes after precipitation and snowmelt events. Figure 4-4 shows the temporal distribution of $\delta^{18} \mathrm{O}$ and $\delta^{2} \mathrm{H}$ values in Tanour spring water. For Tanour spring, shifts to more negative values in response to rainfall and snowmelt events were observed. However, shifts in the isotopic composition from snowmelt water recharge were much more pronounced than for rainfall recharge due to the significantly lower $\delta^{18} \mathrm{O}$ values in water from snowmelt. For the first snowfall event (6-8/01/2015), a change in $\delta^{18} \mathrm{O}$ and $\delta^{2} \mathrm{H}$ values in Tanour spring from melt water was noticed after 7 days (15/01/2015) and a maximum of melt water discharge was reached after 11 days (19/01/2015). $\delta^{18} \mathrm{O}$ and $\delta^{2} \mathrm{H}$ shifted from -6.44 \%o to $7.17 \%$ and $-30.22 \%$ to $-32.53 \%$, respectively. A second shift to more negative $\delta^{18} \mathrm{O}$ and $\delta^{2} \mathrm{H}$ values in Tanour spring discharge was observed after an intensive storm followed by a second snowfall event in mid-February (19-21/02/2015). Spring discharge declined from a value of $6.42 \%$ to $-7.07 \%$ for $\delta^{18} \mathrm{O}$, and from $-30.22 \%$ to $-32.68 \%$ for $\delta^{2} \mathrm{H}$. Discharge of melt water reached a maximum 5 days after the snowfall event on 26/02/2015.

Recharge and spring response at Tanour spring are linked to precipitation amount, air temperature, and hence, the state of precipitation. During the first snowfall event in the beginning of January 2015, minimum air temperatures were below zero and maximum air temperatures were around zero during and one week after the event. Therefore, snow melted slowly, leading to delayed recharge of isotopically depleted melt water. Consequently, spring response showed a decline in $\delta^{18} \mathrm{O}$ and $\delta^{2} \mathrm{H}$ values about one week after the snowfall event. In contrast, the second snowfall event was preceded and followed by rainfall and air temperatures persisted below zero only during the time of snowfall and increased to values around $4{ }^{\circ} \mathrm{C}$ soon thereafter. Therefore, snow melted quickly and melt water was recharged immediately following the event. The increase in air temperature in addition to subsequent rainfall following the snowfall event accelerated the recharge process within the karst features of the catchment, and resulted in a direct response of Tanour spring discharge to the precipitation (rainfall, snowmelt) event by an immediate decrease in $\delta^{18} \mathrm{O}$ and $\delta^{2} \mathrm{H}$ values in spring water. 
Table 4-3: Stable isotopes $\left(\delta^{18} O\right.$ and $\left.\delta^{2} H\right)$ results for Tanour spring.

\begin{tabular}{|c|c|c|c|c|c|c|c|c|}
\hline Date & $\delta^{18} \mathrm{O} \%$ & $\delta^{2} H \%$ & Date & $\delta^{18} \mathrm{O} \%$ & $\delta^{2} H \%$ & Date & $\delta^{18} \mathrm{O} \%$ & $\delta^{2} H \%$ o \\
\hline 10.12 .2014 & -6.38 & -29.40 & 17.01.2015 & -6.89 & -32.10 & 24.02.2015 & -6.91 & -32.14 \\
\hline 11.12 .2014 & -6.35 & -29.35 & 18.01.2015 & -6.85 & -32.02 & 25.02.2015 & -7.03 & -32.57 \\
\hline 12.12.2014 & -6.40 & -29.33 & 19.01.2015 & -7.17 & -32.53 & 26.02.2015 & -7.07 & -32.68 \\
\hline 13.12.2014 & -6.40 & -29.05 & 20.01 .2015 & -7.13 & -32.65 & 27.02.2015 & -6.94 & -32.44 \\
\hline 14.12.2014 & -6.40 & -28.84 & 21.01.2015 & -7.03 & -32.69 & 28.02 .2015 & -6.77 & -31.70 \\
\hline 15.12 .2014 & -6.49 & -28.88 & 22.01 .2015 & -6.69 & -31.97 & 01.03 .2015 & -6.80 & -31.78 \\
\hline 16.12.2014 & -6.47 & -28.87 & 23.01 .2015 & -6.64 & -32.25 & 02.03 .2015 & -6.77 & -31.65 \\
\hline 17.12 .2014 & -6.39 & -28.93 & 24.01 .2015 & -6.70 & -32.10 & 03.03.2015 & -6.76 & -31.45 \\
\hline 18.12 .2014 & -6.39 & -29.11 & 25.01 .2015 & -6.64 & -31.60 & 04.03 .2015 & -6.79 & -31.56 \\
\hline 19.12.2014 & -6.41 & -29.01 & 26.01.2015 & -6.72 & -31.42 & 05.03.2015 & -6.79 & -31.10 \\
\hline 20.12.2014 & -6.50 & -29.33 & 27.01 .2015 & -6.73 & -31.51 & 06.03 .2015 & -6.59 & -30.30 \\
\hline 21.12.2014 & -6.48 & -29.19 & 28.01.2015 & -6.73 & -31.22 & 07.03.2015 & -6.54 & -30.87 \\
\hline 22.12.2014 & -6.52 & -29.05 & 29.01 .2015 & -6.81 & -30.84 & 08.03.2015 & -6.36 & -31.19 \\
\hline 23.12.2014 & -6.46 & -28.95 & 30.01 .2015 & -6.67 & -30.87 & 09.03.2015 & -6.37 & -30.76 \\
\hline 24.12 .2014 & -6.61 & -29.62 & 31.01 .2015 & -6.74 & -30.90 & 10.03 .2015 & -6.33 & -30.33 \\
\hline 27.12 .2014 & -6.52 & -30.50 & 01.02 .2015 & -6.69 & -30.67 & 11.03 .2015 & -6.38 & -28.95 \\
\hline 28.12.2014 & -6.33 & -29.56 & 02.02.2015 & -6.54 & -30.43 & 12.03.2015 & -6.48 & -29.53 \\
\hline 29.12.2014 & -6.43 & -30.29 & 03.02 .2015 & -6.74 & -30.45 & 13.03.2015 & -6.40 & -29.54 \\
\hline 30.12 .2014 & -6.46 & -30.50 & 2015 & -6.75 & -30.67 & 14.03 .2015 & -6.41 & -29.69 \\
\hline 31.12 .2014 & -6.52 & -30.63 & 05.02 .2015 & -6.64 & -30.74 & 15.03 .2015 & -6.43 & -29.41 \\
\hline 01.01 .2015 & -6.53 & -30.09 & 06.02 .2015 & -6.52 & -30.50 & 16.03.2015 & -6.37 & -29.26 \\
\hline 02.01 .2015 & -6.55 & -30.07 & 07.02 .2015 & -6.52 & -30.40 & 17.03 .2015 & -6.51 & -29.40 \\
\hline 03.01.2015 & -6.48 & -30.20 & 08.02.2015 & -6.63 & -30.20 & 18.03.2015 & -6.48 & -29.31 \\
\hline 04.01 .2015 & -6.51 & -30.55 & 09.02 .2015 & -6.60 & -30.28 & 19.03.2015 & -6.38 & -29.43 \\
\hline 05.01 .2015 & -6.47 & -30.68 & 10.02 .2015 & -6.56 & -30.25 & 20.03.2015 & -6.29 & -29.40 \\
\hline 07.01 .2015 & -6.54 & -30.42 & 12.02 .2015 & -6.47 & -30.18 & 21.03 .2015 & -6.37 & -29.16 \\
\hline 08.01 .2015 & -6.51 & -30.71 & 13.02.2015 & -6.42 & -30.22 & 22.03 .2015 & -6.56 & -29.50 \\
\hline 09.01 .2015 & -6.59 & -30.14 & 15.02 .2015 & -6.69 & -30.90 & 23.03 .2015 & -6.55 & -29.51 \\
\hline 10.01 .2015 & -6.54 & -30.32 & 16.02 .2015 & -6.76 & -31.21 & 24.03 .2015 & -6.47 & -29.64 \\
\hline 11.01 .2015 & -6.51 & -30.36 & 17.02 .2015 & -6.75 & -31.07 & 25.03 .2015 & -6.41 & -29.87 \\
\hline 12.01 .2015 & -6.47 & -30.55 & 19.02.2015 & -6.68 & -31.31 & 26.03 .2015 & -6.49 & -29.50 \\
\hline 13.01 .2015 & -6.54 & -30.55 & 20.02 .2015 & -6.67 & -30.92 & 27.03.2015 & -6.48 & -29.85 \\
\hline 14.01 .2015 & -6.46 & -30.20 & 21.02 .2015 & -6.72 & -31.36 & 28.03.2015 & -6.57 & -29.50 \\
\hline 15.01 .2015 & -6.44 & -30.22 & 22.02.2015 & -6.75 & -31.47 & 29.03 .2015 & -6.46 & -29.85 \\
\hline 16.01 .2015 & -6.49 & -30.04 & 23.02.2015 & -6.81 & -31.72 & 30.03 .2015 & -6.46 & -29.97 \\
\hline
\end{tabular}




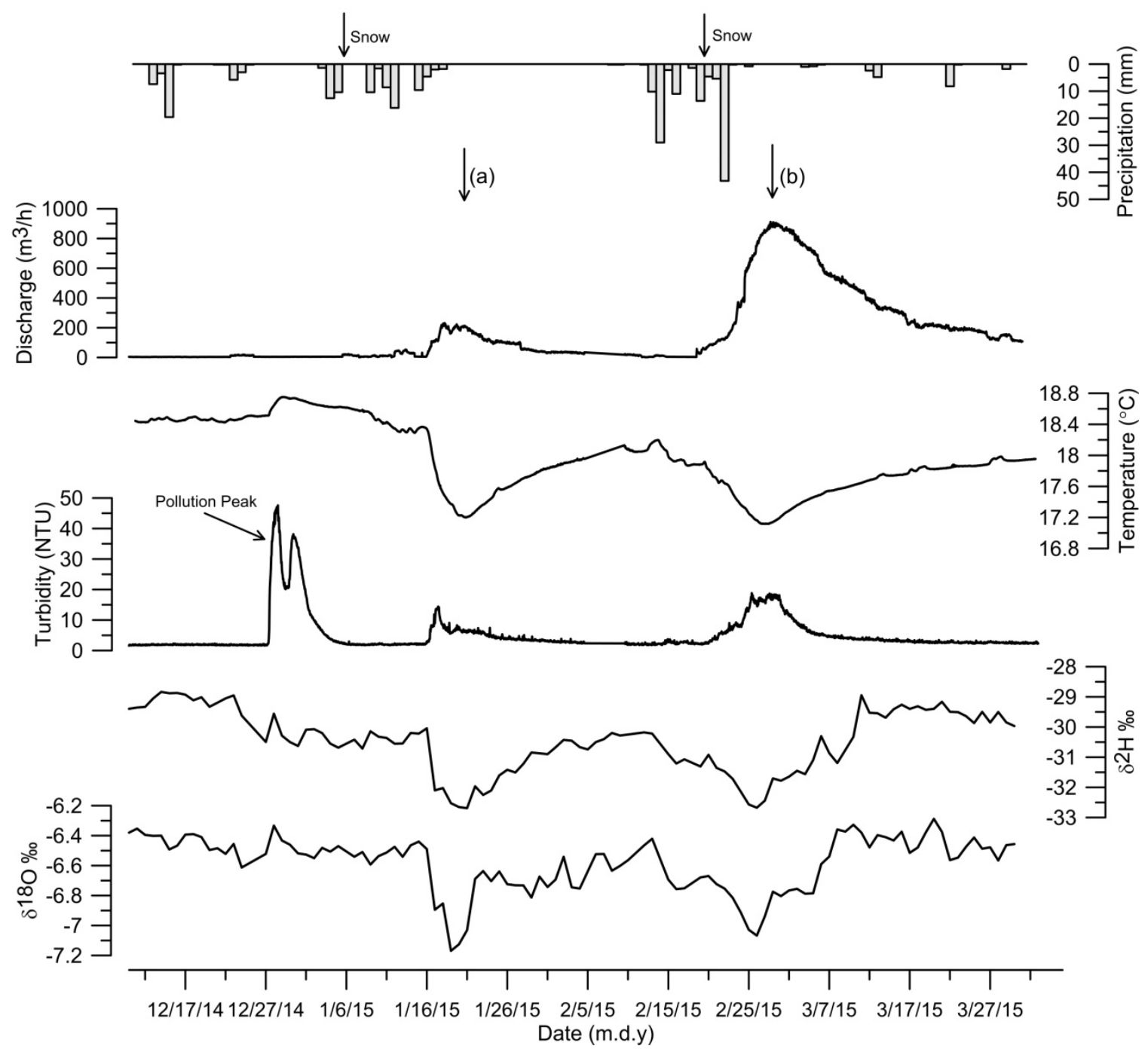

Figure 4-4: Variation in $\delta^{18} O, \delta^{2} H$ in parallel with the other monitored parameters in Tanour spring water in response to rainfall and snow events (Hamdan et al. 2016).

Due to fast response to recharge events and short water travel times, karst aquifer systems are generally susceptible to pollution. In the catchment area of Tanour spring, pollution from waste water leakage of sewage systems, farming activities, and olive mills is a common problem. The Ministry of Water and Irrigation (MWI) in cooperation with the Federal Institute for Geosciences and Natural Resources, Germany (BGR) have started to monitor Tanour spring for multi-spatial variable parameters by using automated continuous measurement devices. From this monitoring system, data for water temperature $\left({ }^{\circ} \mathrm{C}\right)$, spring discharge $\left(\mathrm{m}^{3} / \mathrm{h}\right)$ and turbidity (NTU) were recorded for the sampling period (MWI-BGR 2015). Turbidity and water temperature can be 118 
used in conjunction with $\delta^{2} \mathrm{H}$ and $\delta^{18} \mathrm{O}$ values to obtain further information about water travel time in karst aquifers.

Figure 4-4 shows that water temperature and turbidity values in Tanour spring parallel the trends of $\delta^{18} \mathrm{O}$ and $\delta^{2} \mathrm{H}$ values. Increases in turbidity in spring water reflect the rapid response to precipitation events, and are either related to direct water recharge from the surface or to fast water flow in conduits or both. Figure 4-4 shows different turbidity peaks in Tanour spring water. An elevated turbidity peak related to pollution by wastewater from olive mills was recorded end of December 2014 until the beginning of January 2015. Two further events of increased turbidity coincide with negative excursions of $\delta^{18} \mathrm{O}$ and $\delta^{2} \mathrm{H}$ values and are therefore related to discharge of water from snowmelt and rainfall events (Figure 4-4, peak a and b). Parallel, spring water temperature decreases. During discharge of melt water from snow, the temperature of Tanour spring decreased from $18.4^{\circ} \mathrm{C}$ to $17.2 \mathrm{C}^{\circ}$ and from $18.2^{\circ} \mathrm{C}$ to $17.1^{\circ} \mathrm{C}$ for the first and the second snowmelt event, respectively. The good agreement of water temperature, turbidity, and the distribution of $\delta^{18} \mathrm{O}$ and $\delta^{2} \mathrm{H}$ values implies that water flow within the unsaturated portion of the Tanour aquifer system is fast, following recharge from rainfall and snowmelt events. Spring discharge data showed a good agreement with $\delta^{18} \mathrm{O}, \delta^{2} \mathrm{H}$, water temperature, and turbidity data during the recharge events. Figure 4-4 shows that spring discharge increased simultaneously with the other monitored parameters to values of $250 \mathrm{~m}^{3} / \mathrm{h}$ and $900 \mathrm{~m}^{3} / \mathrm{h}$ as displayed in peaks (a) and (b), respectively.

During the two recharge events, the turbidity increased to values around 15-20 NTU simultaneously with the water temperature, spring discharge, and the isotopic composition of the spring water. On the other hand, during the pollution event, turbidity increased to values around 45 NTU without any changes in spring discharge, water temperature or isotopic composition. The high turbidity peak during the pollution event is related to recharge of olive press waste water. The influence of waste water is also reflected in oily spring water discharge that shows a dark green or black color because of high concentrations of organic and phenolic compounds. Depending on the distance of olive mills to Tanour spring in addition to random illegal dumping of pollutants within the catchment (either in wadis, large conduits, or caves), the travel time of pollutants within the aquifer and to Tanour spring remains uncertain. Further, precipitation duration and intensity affect water travel times within the catchment and aquifer. 


\subsubsection{Rasoun spring response to precipitation events using $\delta^{18} \mathrm{O}$ and $\delta^{2} \mathrm{H}$}

For the sampling period between November 2014 and March 2015, $\delta^{18} \mathrm{O}$ and $\delta^{2} \mathrm{H}$ values of Rasoun spring water range from $-6.15 \%$ to $-7.49 \%$ o (average value of $-6.64 \pm 0.23 \%$ o) for $\delta^{18} \mathrm{O}$, and from $-28.23 \%$ to $-34.46 \%$ (average value of $-30.29 \pm 1.22 \%$ ) for $\delta^{2} \mathrm{H}$. Figure $4-5$ shows the temporal distribution of $\delta^{18} \mathrm{O}$ and $\delta^{2} \mathrm{H}$ values in Rasoun spring water discharge. All stable isotope $\left(\delta^{18} \mathrm{O}\right.$ and $\left.\delta^{2} \mathrm{H}\right)$ results for Rasoun spring are presented in (Table 4-4).

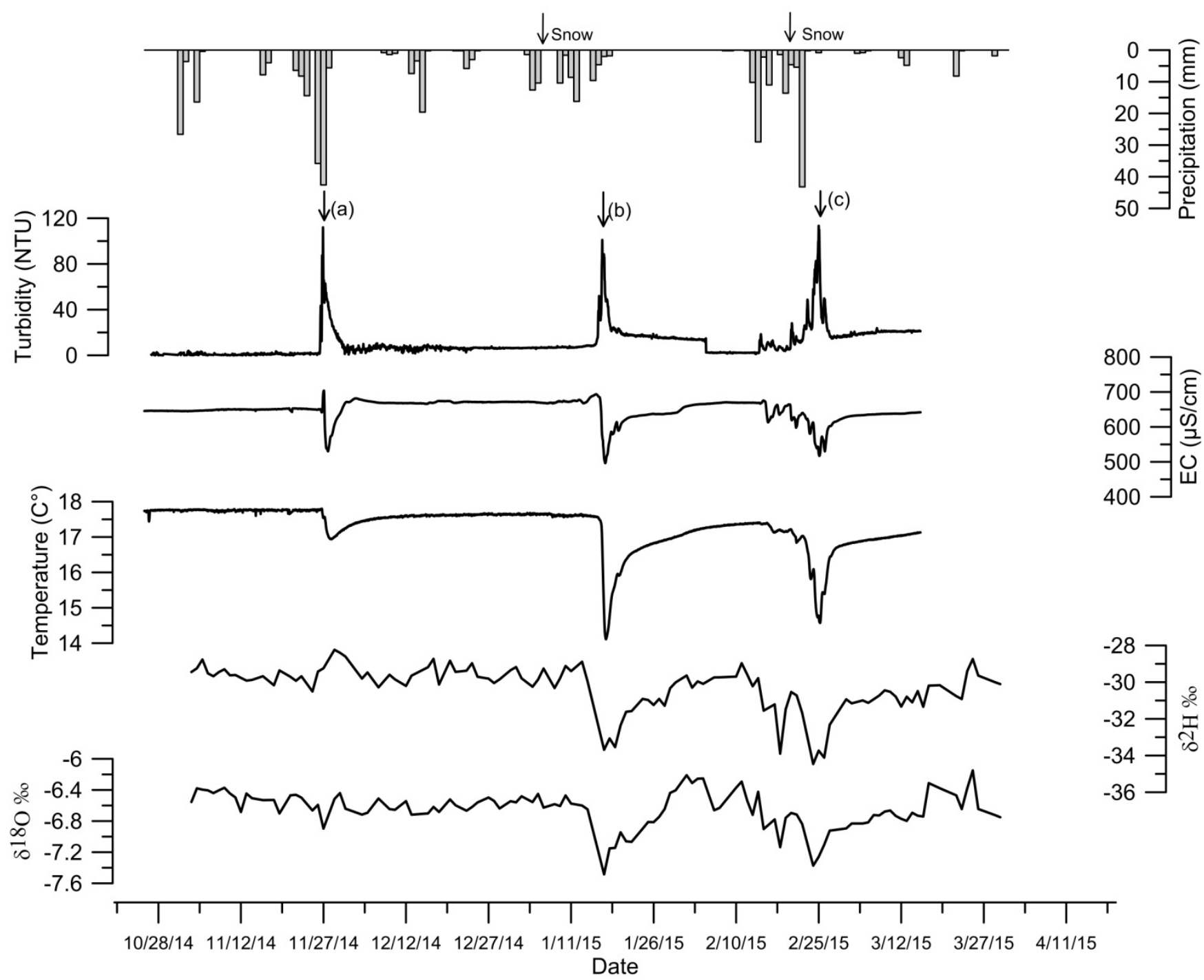

Figure 4-5: Variation in $\delta^{18} O, \delta^{2} \mathrm{H}$ in parallel with the other monitored parameters in Rasoun spring water in response to rainfall and snow events. 
Table 4-4: Stable isotopes $\left(\delta^{18} O\right.$ and $\left.\delta^{2} H\right)$ results for Rasoun spring.

\begin{tabular}{|c|c|c|c|c|c|c|c|c|}
\hline Date & $\delta^{18} \mathrm{O} \%$ & $\delta^{2} H$ \% & Date & $\delta^{18} \mathrm{O} \%$ & $\delta^{2} H$ \%o & Date & $\delta^{18} \mathrm{O} \%$ & $\delta^{2} H$ \%o \\
\hline 03.11 .2014 & -6.55 & -29.45 & 25.12 .2014 & -6.56 & -29.71 & 12.02 .2015 & -6.53 & -29.58 \\
\hline 04.11 .2014 & -6.38 & -29.24 & 27.12.2014 & -6.50 & -29.81 & 13.02 .2015 & -6.72 & -30.22 \\
\hline 05.11 .2014 & -6.40 & -28.77 & 28.12.2014 & -6.54 & -30.05 & 14.02.2015 & -6.42 & -29.78 \\
\hline 06.11 .2014 & -6.41 & -29.52 & 29.12.2014 & -6.64 & -29.85 & 15.02 .2015 & -6.90 & -31.55 \\
\hline 07.11 .2014 & -6.44 & -29.68 & 31.12.2014 & -6.54 & -29.35 & 17.02 .2015 & -6.78 & -31.21 \\
\hline 08.11 .2014 & -6.40 & -29.45 & 01.01 .2015 & -6.56 & -29.18 & 18.02.2015 & -7.14 & -33.90 \\
\hline 09.11.2014 & -6.37 & -29.30 & 02.01 .2015 & -6.48 & -29.79 & 19.02.2015 & -6.76 & -31.48 \\
\hline 10.11.2014 & -6.44 & -29.63 & 04.01 .2015 & -6.56 & -30.25 & 20.02.2015 & -6.70 & -30.53 \\
\hline 11.11.2014 & -6.50 & -29.61 & 05.01 .2015 & -6.45 & -29.86 & 21.02 .2015 & -6.72 & -30.72 \\
\hline 12.11 .2014 & -6.68 & -29.76 & 06.01 .2015 & -6.63 & -29.26 & 22.02 .2015 & -6.84 & -31.68 \\
\hline 13.11.2014 & -6.45 & -29.91 & 08.01.2015 & -6.58 & -30.32 & 24.02 .2015 & -7.37 & -34.46 \\
\hline 14.11.2014 & -6.51 & -29.88 & 09.01 .2015 & -6.61 & -29.79 & 25.02.2015 & -7.26 & -33.73 \\
\hline 16.11.2014 & -6.53 & -29.68 & 10.01 .2015 & -6.47 & -29.12 & 26.02 .2015 & -7.10 & -34.11 \\
\hline 18.11.2014 & -6.53 & -30.17 & 11.01 .2015 & -6.58 & -29.40 & 27.02.2015 & -6.92 & -32.32 \\
\hline 19.11.2014 & -6.70 & -29.36 & 13.01 .2015 & -6.60 & -28.89 & 02.03.2015 & -6.89 & -30.93 \\
\hline 21.11.2014 & -6.47 & -29.71 & 14.01 .2015 & -6.65 & -29.96 & 03.03.2015 & -6.83 & -31.16 \\
\hline 22.11.2014 & -6.46 & -29.93 & 17.01 .2015 & -7.49 & -33.69 & 05.03.2015 & -6.83 & -30.99 \\
\hline 23.11.2014 & -6.50 & -29.68 & 18.01.2015 & -7.15 & -33.07 & 06.03.2015 & -6.82 & -31.13 \\
\hline 25.11.2014 & -6.66 & -30.51 & 19.01.2015 & -7.14 & -33.54 & 07.03.2015 & -6.72 & -30.93 \\
\hline 26.11.2014 & -6.59 & -29.42 & 20.01 .2015 & -6.94 & -32.35 & 08.03.2015 & -6.73 & -30.73 \\
\hline 27.11.2014 & -6.90 & -29.24 & 21.01 .2015 & -7.06 & -31.62 & 09.03.2015 & -6.68 & -30.44 \\
\hline 29.11.2014 & -6.52 & -28.23 & 22.01.2015 & -7.07 & -31.58 & 10.03 .2015 & -6.66 & -30.53 \\
\hline 30.11 .2014 & -6.44 & -28.40 & 24.01.2015 & -6.90 & -30.91 & 11.03 .2015 & -6.73 & -30.79 \\
\hline 01.12 .2014 & -6.64 & -28.61 & 25.01.2015 & -6.81 & -30.97 & 12.03 .2015 & -6.77 & -31.33 \\
\hline 04.12 .2014 & -6.72 & -29.80 & 26.01.2015 & -6.81 & -31.24 & 13.03.2015 & -6.80 & -30.79 \\
\hline 05.12.2014 & -6.69 & -29.47 & 27.01 .2015 & -6.75 & -30.91 & 14.03 .2015 & -6.69 & -31.10 \\
\hline 07.12 .2014 & -6.51 & -30.28 & 28.01 .2015 & -6.65 & -31.29 & 15.03.2015 & -6.73 & -30.49 \\
\hline 09.12.2014 & -6.65 & -29.60 & 29.01 .2015 & -6.44 & -30.33 & 16.03 .2015 & -6.74 & -31.34 \\
\hline 10.12.2014 & -6.66 & -29.85 & 30.01 .2015 & -6.40 & -30.01 & 17.03 .2015 & -6.31 & -30.19 \\
\hline 12.12.2014 & -6.54 & -30.21 & 01.02 .2015 & -6.21 & -29.64 & 19.03.2015 & -6.38 & -30.17 \\
\hline 13.12.2014 & -6.72 & -29.65 & 02.02 .2015 & -6.31 & -30.30 & 22.03.2015 & -6.47 & -30.76 \\
\hline 16.12.2014 & -6.70 & -29.18 & 03.02 .2015 & -6.26 & -29.96 & 23.03 .2015 & -6.65 & -30.92 \\
\hline 17.12.2014 & -6.62 & -28.73 & 04.02.2015 & -6.25 & -30.09 & 24.03.2015 & -6.38 & -29.39 \\
\hline 18.12.2014 & -6.68 & -30.13 & 06.02 .2015 & -6.66 & -29.74 & 25.03.2015 & -6.15 & -28.74 \\
\hline 20.12 .2014 & -6.52 & -28.83 & 07.02.2015 & -6.63 & -29.74 & 26.03 .2015 & -6.64 & -29.64 \\
\hline 21.12.2014 & -6.60 & -29.44 & 10.02 .2015 & -6.37 & -29.70 & 29.03 .2015 & -6.72 & -30.00 \\
\hline 23.12.2014 & -6.67 & -29.37 & 11.02 .2015 & -6.29 & -28.97 & 30.03.2015 & -6.75 & -30.10 \\
\hline 24.12.2014 & -6.62 & 2807 & & & & & & \\
\hline
\end{tabular}


Rasoun spring showed a very fast response to precipitation events. Both of $\delta^{18} \mathrm{O}$ and $\delta^{2} \mathrm{H}$ shifts to more negative values in response to rainfall and snowmelt events. Shift to more negative in $\delta^{18} \mathrm{O}$ and $\delta^{2} \mathrm{H}$ values in Rasoun spring water is more clear after the snow events than the rain events due to the high depleted value of $\delta^{18} \mathrm{O}$ and $\delta^{2} \mathrm{H}$ in the snow melt water than the rain. During the sampling period, three recharge events were measured in Rasoun spring (Figure 4-5, peaks a, b, and c).

Different parameters play an important role in the spring response to the precipitation events such as: the precipitation amount and intensity and air temperature. Direct change in Rasoun water isotopic composition was occurred directly during an intensive rainfall event between 2228/11/2014. In total $110 \mathrm{~mm}$ rain fell; around $90 \mathrm{~mm}$ fell between 26-28/11/2014. The $\delta^{18} \mathrm{O}$ shifted directly from $-6.46 \%$ to $-6.90 \%$ to reach the maximum in 27/11/2014 (2 days from the start of the intensive rainfall) (Figure 4-5, peak a).

Changing in the weather conditions plays a big role in the water travel time and the changing in the isotopic composition of Rasoun spring water after the snow events. For the first snowfall event (6-8/01/2015), a change in $\delta^{18} \mathrm{O}$ and $\delta^{2} \mathrm{H}$ values in Rasoun spring from snowmelt water was noticed after 5 days (13/01/2015) and a maximum of melt water discharge was reached after 9 days (17/01/2015) (Figure 4-5, peak b). $\delta^{18} \mathrm{O}$ and $\delta^{2} \mathrm{H}$ shifted from $-6.60 \%$ to $-7.49 \%$ and $28.89 \%$ to $-33.69 \%$, respectively. During the first snowfall event, the snow was melted slowly due to the very low air temperature which is around zero. This very low temperatures leading to delayed recharge of isotopically depleted melt water. Consequently, Rasoun spring showed a decline in $\delta^{18} \mathrm{O}$ and $\delta^{2} \mathrm{H}$ values about 5 days after the snowfall event.

A second shift to more negative $\delta^{18} \mathrm{O}$ and $\delta^{2} \mathrm{H}$ values in Rasoun spring discharge was observed directly after an intensive storm followed by a second snowfall event (19-21/02/2015). The isotopic composition of Rasoun spring declined from a value of $-6.72 \%$ to $-7.37 \%$ for $\delta^{18} \mathrm{O}$, and from $-30.72 \%$ to $-34.46 \%$ for $\delta^{2} \mathrm{H}$. Discharge of snowmelt water reached a maximum after 3 days (24/02/2015) (Figure 4-5, peak c). The direct and quick response of Rasoun spring for the second snowfall event is due to that the snowfall was preceded and followed by rainfall and air temperatures persisted below zero only during the time of snowfall and increased to values around $4{ }^{\circ} \mathrm{C}$ soon thereafter. The increase in air temperature in addition to subsequent rainfall following the snowfall event accelerated the snow melt and recharge process within the karst 
features of the catchment, and resulted in a direct response of Rasoun spring discharge to the precipitation event by an immediate decrease in $\delta^{18} \mathrm{O}$ and $\delta^{2} \mathrm{H}$ values in spring water.

During the sampling period, other different parameters were monitored in Rasoun spring in parallel to the stable isotopes of oxygen and hydrogen in order to investigate the Rasoun spring response to precipitation events. These monitored parameters are: water temperature $\left({ }^{\circ} \mathrm{C}\right)$, electrical conductivity $(\mu \mathrm{S} / \mathrm{cm}$ ), and turbidity (NTU). These parameters followed the same trend of $\delta^{18} \mathrm{O}$ and $\delta^{2} \mathrm{H}$ values during and after the precipitation events. Figure 4-5, a shows that the water temperature in Rasoun spring decreased a little during the discharge from rain water, where the water temperature decreased from $17.8^{\circ} \mathrm{C}$ to $16.9^{\circ} \mathrm{C}$. On the other hand, during the spring discharge from the snowmelt water, the water temperature of Rasoun spring decreased from $17.5^{\circ} \mathrm{C}$ to $14.1{ }^{\circ} \mathrm{C}$ for the first snowmelt event (Figure 4-5, b), and from $17.1^{\circ} \mathrm{C}$ to $14.6^{\circ} \mathrm{C}$ for the second snowmelt event (Figure 4-5, c). This variation in the water temperature decreasing range is due to the difference between the rainwater temperature and the snowmelt water temperature.

During the three recharge events, the turbidity value increased to around 100 - 115 NTU simultaneously with the water temperature, electrical conductivity, and the isotopic composition of the spring water. Electrical conductivity showed also the same trend in parallel to the other parameters. The electrical conductivity value during the three recharge events decreased to reach around $490(\mu \mathrm{S} / \mathrm{cm})$.

\subsection{Conclusions}

The LMWL obtained from rain and snow water data in the Tanour and Rasoun springs catchment area $\left(\delta^{2} \mathrm{H}=7.66 * \delta^{18} \mathrm{O}+24.43 \%\right.$ ) plots close to the MMWL and in combination with the high d-excess value of $24.43 \%$ suggests the derivation of air masses and moisture from the Mediterranean Sea as the main source of precipitation. $\delta^{18} \mathrm{O}$ and $\delta^{2} \mathrm{H}$ data of precipitation from this study are in good agreement with historical rainfall data from Ras Munif rain gauge station, which is located close to the investigated catchment. 
The use of coupled physical and geochemical (isotopic) parameters to study karst spring response to precipitation events provides important information for a better understanding of the hydrogeology of karst aquifers in arid regions. Investigations of the stable isotope composition of hydrogen and oxygen as well as water temperature, spring discharge, electrical conductivity, and turbidity data suggest that Tanour and Rasoun springs respond rapidly to precipitation and snowmelt events, and therefore fast groundwater travel times, rapid water transfer between karst features, and low storage in the karst network within the catchment area are implied. The isotopic composition of $\delta^{18} \mathrm{O}$ and $\delta^{2} \mathrm{H}$ in Tanour and Rasoun spring waters showed good agreement with the other monitored parameters in both of the springs regarding to the water travel time in the karst aquifer.

In spite of the fast responses of both Tanour and Rasoun springs to precipitation events, Rasoun spring showed a shorter water travel time (an average of two days) than Tanour spring. Figure 4-6, $\mathrm{t} 1$ and $\mathrm{t} 2$ represent the difference in response time between Tanour and Rasoun springs to precipitation events based on the change in $\delta^{18} \mathrm{O}$ values. The reason for this difference in water travel time between Tanour and Rasoun springs is due to the fact that catchment area of Rasoun spring is smaller than that of Tanour spring, where the catchment area of Rasoun spring is considered as a sub-catchment of Tanour spring catchment area, which means it has a shorter water travel time. In addition to that, it was noticed that Tanour and Rasoun springs have completely different ranges of changes in turbidity, water temperature, and EC value during the recharge events. For example, the water temperature during recharge events decreased in Rasoun spring by around $3-4{ }^{\circ} \mathrm{C}$, while in Tanour spring it decreased by only around $1-1.5^{\circ} \mathrm{C}$; the same was true for turbidity, which increased to around 20 NTU in Tanour spring (except for the pollution event) but reached around 110 NTU in Rasoun spring for the same recharge events. 

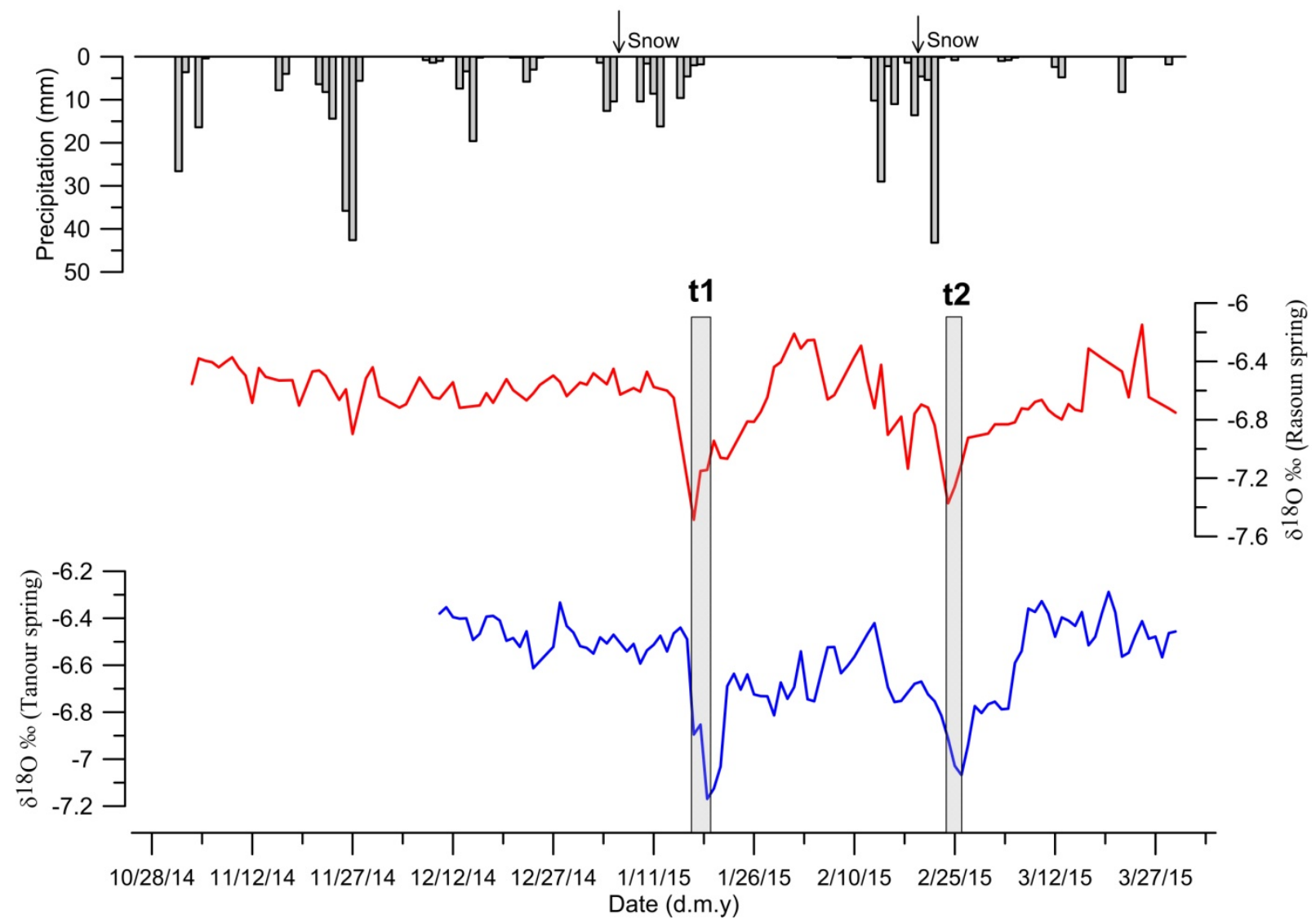

Figure 4-6: Difference in response time between Tanour and Rasoun springs (t1, t2) based on the change in $\delta^{18} \mathrm{O}$ values.

Based on the isotopic composition of Tanour and Rasoun springs during the recharge events, it was noticed that $\delta^{18} \mathrm{O}$ is highly depleted in Rasoun spring compared to Tanour spring. The calculated difference between Tanour and Rasoun springs during the recharge events was around $0.30 \%$ for $\delta^{18} \mathrm{O}$. The reason for the difference can be attributed to several factors, such as the difference in elevation between Tanour and Rasoun springs, as Rasoun spring is around $120 \mathrm{~m}$ higher than Tanour spring, and the catchment size, as the catchment area of Rasoun spring is smaller than that of Tanour spring. These factors mean that the water travel time is shorter in Rasoun spring than in Tanour spring, and thus the isotopic signal in Rasoun spring will be more depleted than in Tanour spring and more affected by the snowmelt signal. Figure 4-7 represents the deviation of Tanour and Rasoun springs samples from the LMWL during normal base flow conditions and recharge events. Figure 4-7 shows that Rasoun spring water samples cluster has wider distribution and higher deviation towards the LMWL than Tanour spring, which means 
there is a faster connection between surface and spring and then a more direct effect of precipitation on the spring water (short water travel time).

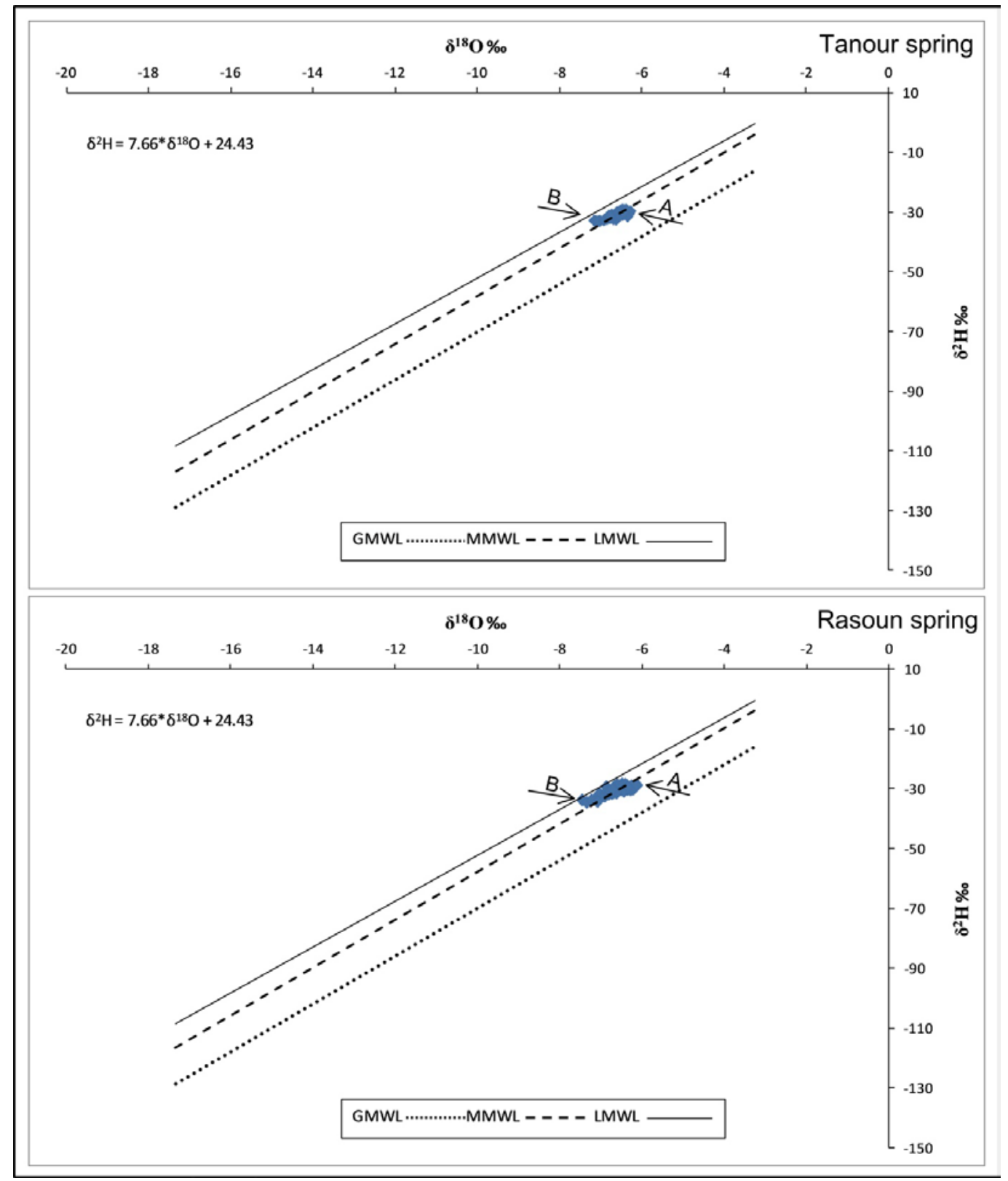

Figure 4-7: Deviation of Tanour and Rasoun springs isotopic composition from the LMWL during normal base flow conditions (point A), and recharge events (point B).

Compared to the high variability in $\delta^{18} \mathrm{O}$ and $\delta^{2} \mathrm{H}$ values of rainfall and snow water samples collected in the catchment, the isotopic composition of oxygen and hydrogen in both Tanour and 
Rasoun springs exhibits a small variation in spring discharge. This small variation suggests a well-mixed and large-scale groundwater aquifer.

\subsection{References}

Al-Ameri A., Schneider M., Abu Lohom N., Sprenger C. (2014) The hydrogen ( $\delta D)$ and oxygen $\left(\delta^{18} \mathrm{O}\right)$ isotopic composition of Yemen's rainwater. Arab J Sci Eng. 39:423-436; doi 10.1007/s13369-013-0869-6.

Bajjali W. (1990) Isotopic characteristic of precipitation in Jordan. International symposium on the use of isotope technique in water resources development. IAEA-SM-319/61p; Vienna, Austria (cited in Bajjali 2012).

Bajjali W. (1994) Hydrochemistry and isotope hydrology of thermal groundwater's in northern Jordan. PhD dissertation. University of Ottawa, Canada.

Bajjali W., Clark I D., Fritz P. (1997) The artesian thermal groundwater's of northern Jordan: insights to their origin and subsurface history. Journal of Hydrology. 192:355-382.

Bajjali W. (2006) Recharge mechanism and hydrochemistry evaluation of groundwater in the Nuaimeh area, Jordan, using environmental isotope techniques. Hydrogeology Journal. 14:180-191; doi 10.1007/s10040-004-0352-2.

Bajjali W., Abu-Jaber N. (2001) Climatological signals of the paleogroundwater in Jordan. Journal of Hydrology. 243:133-147.

Bajjali W. (2012) Spatial variability of environmental isotope and chemical content of precipitation in Jordan and evidence of slight changes in climate. Applied Water Sci. Journal. 2:271-283; doi 10.1007/s13201-012-0046-1.

Butscher C., Huggenberger P. (2009) Modeling the temporal variability of karst groundwater vulnerability, with implication for climate change. Environmental Science and Technology. 43(6):1665-1669; doi 10.1021/es801613g. 
Craig H. (1961) Standard for reporting concentrations of deuterium and oxygen-18 in Natural Waters. Science. 133:1833-1834.

Dansgaard W. (1964) Stable isotopes in precipitation. Tellus. 16:436-468.

Ettayfi N., Bouchaou L., Michelot J., Tagma T., Warner N., Boutaleb S., Massault M., Lgourna Z., Venfosh A. (2012) Geochemical and isotopic (oxygen, hydrogen, carbon, strontium) constraints for the origin, salinity, and residence time of groundwater from a carbonate aquifer in the western Anti-Atlas mountains, Morocco. Journal of Hydrology. 438-439:97-111; doi:10.1016/j.jhydrol.2009.10.019.

Gat J R., Carmi I. (1970) Evolution of the isotopic composition of atmospheric waters in the Mediterranean sea area. Journal of Geophysical Research. 75(15):3039-3048.

Gat J R., Dansgaard W. (1972) Stable isotope survey of the fresh water occurrences in Israel and the northern Jordan rift valley. Journal of Hydrology. 16:177-212.

Gat J R., Carmi I. (1987) Effect of climate changes on the precipitation patterns and isotope composition of water in a climate transition zone - case of the eastern Mediterranean sea area. In: Solomon S.I., Beran M., Hogg W. (eds): The influence of climate change and climate variability on the hydrologic regime and water resources. Wallingford: International Association of Hydrological Sciences (IAHS) publication No. 168: 513523. Canada.

Gat R J. (1996) Oxygen and hydrogen isotopes in the hydrologic cycle. Annu. Rev. Earth planet. Sci. 24:225-262.

Hamdan I, Wiegand B, Toll M, Sauter M (2016) Spring response to precipitation events using $\delta^{18} \mathrm{O}$ and $\delta^{2} \mathrm{H}$ in the Tanour catchment, NW Jordan, Isotopes in Environmental and Health Studies Journal. http://dx.doi.org/10.1080/10256016.2016.1159205.

IAEA/WMO (July 2015) Global network of isotopes in precipitation. The GNIP database; historical data. Accessed: July 2015. Available from: http://www.iaea.org/water.

Khayat S. (2005) Hydrochemistry and isotope hydrogeology in the Jericho area/Palestine. PhD dissertation. University of Karlsruhe, Germany. 
Lakey B., Krothe N. (1996) Stable isotopic variation of storm discharge from perennial karst spring, Indiana. Water Resources Research. 32(3):721-731.

Marshall J D., Brooks J. R., Lajtha K. (2007) Sources of variation in the stable isotopic composition of plants. In: Michener R., Lajtha A K. (eds): Stable Isotopes in Ecology and Environmental Science. Second edition. Blackwell Publishing, p. 22-60.

Mazor E. (2004) Chemical and Isotopic Groundwater Hydrology. Third Edition. Marcel Dekker, Inc., New York, 453 p.

Morales T., de Valderrama I., Uriarte J., Antigüedad I., Olazar M. (2007) Predicting travel times and transport characterization in karst conduits by analyzing tracer-breakthrough curves. Journal of Hydrology. 334:183-198; doi:10.1016/j.jhydrol.2006.10.006.

MWI (Ministry of Water and Irrigation) (2015) Daily minimum and maximum temperature, and daily rainfall amount data for Ras Munif station (AH0003) for the winter season 2014/2015 (soft copy). Water information system, national master plan directorate. Amman, Jordan (unpublished).

MWI (Ministry of Water and Irrigation) - BGR (Federal Institute for Geosciences and Natural Resources) (2015) Automated online regular and continuous data measurement from Tanour spring for water temperature, spring discharge and turbidity values for the winter season 2014/2015 (soft copy). Amman, Jordan (unpublished).

Rindsberger M., Margritz M., Carmi I., Gilad D. (1983) The relation between air mass trajectories and the water isotope composition of rain in the Mediterranean sea area. Geophysical Research Letters. 10(1):43-46.

Saad Z., Kazpard V., Samrani A., Slim K. (2005) Chemical and isotopic composition of rainwater in coastal and highland regions in Lebanon. Journal of Environmental Hydrology. 13:1-11.

Salameh E. (2004) Using environmental isotopes in the study of recharge - discharge mechanism of the Yarmouk catchment area in Jordan. Hydrogeology Journal. 12:451463; doi 10.1007/s10040-004-0357-x.

Sami K. (1992) Recharge Mechanism and Geochemical Processes in a Semi-Arid Sedimentary Basi, Eastern Cape, South Africa, Journal of Hydrology. 139:27-48. 
WAJ (Water Authority of Jordan, Ministry of Water and Irrigation) (2002) Open file report. Amman, Jordan (Cited in Salameh 2004). 


\section{Chapter five: Investigating the karst aquifers}

response to precipitation and pollution events using multi-monitored parameters for groundwater travel time

Related article to this chapter:

> Hamdan I, Licha T, Toll M, Margane A, Sauter M. Quantification of wastewater pollution load using potassium concentrations in karst spring discharge. Under preparation. 


\subsection{Introduction}

Water quality in karst aquifers is a very complicated issue. The unique and heterogeneous hydrogeological characteristics of karst aquifers, besides the direct, focused and rapid connection between the land surface and the ground water systems that allow a concentrated and rapid inflow, make karst aquifers extremely sensitive to anthropogenic contamination resulting from surface and land-use activities (Mahler et al. 2000, Heinz et al. 2009, Schiperski et al. 2015a). Many processes of contaminant attenuation like filtration and adsorption, as well as chemical and microbiological decay, are greatly limited and often do not work effectively in karst systems due to the short water-rock interaction, thin or absent soil cover in the karstic areas, fast vertical and horizontal water travel times through the karstic layers, low storage capacity in the conduit system, and the lack of filtration in the aquifer (Kacaroglu 1999, Zwahlen et al. 2003, Heinz et al. 2009, Erb et al. 2015).

According to Schiperski et al. (2015a), the rapid changes in the water temperature, electrical conductivity, and turbidity represent a good indicator about the recharge events that occurred in the karst aquifers. Based on Pronk et al. (2006; 2009), recharge within karst areas can be divided into two types; (1) autogenic recharge: where water infiltrates diffusely within the soil and unsaturated zone, and (2) allogenic recharge: due the concentrated flow of water via swallow holes. Based on that, turbidity in the karst aquifers has two types: (1) primary or autochthonous turbidity: this type of turbidity is observed directly during or shortly after storm rainfall events, where it occurs from the remobilisation of "intrakarstic" sediments because of the increasing in the flow velocities after the rain events, and (2) secondary or allochthonous turbidity: this type of turbidity reaches the karst spring later after the rainfall event, or sometimes simultaneously with the discharge decreasing, where it happened due to the infiltration of the high turbid water directly into the swallow hole.

Monitoring and analysing different groundwater qualitative and quantitative parameters in karst springs can be used as a good indicator in order to understand the groundwater flow processes and the water and pollutants travel time through the aquifer during and after precipitation events. Different studies have used different monitoring parameters such as water temperature, turbidity, and electrical conductivity, in order to study the response of the karst springs to precipitation 
events, and to determine water travel and residence time (e.g. Martin and Dean 1999, Pronk et al. 2006, Schiperski et al. 2015b).

Determining water travel time in the karst aquifer of Tanour and Rasoun springs is very important for understanding the karst aquifer characteristics and its response during and after recharge events, especially considering that both springs suffer from pollution from domestic wastewater leakage from septic tanks, and from olive mills wastewater. Total Coliform bacteria are naturally available in the environment like soil and vegetation, as well as from the intestines of mammals, including humans. Escherichia Coli (fecal bacteria) are the only member from the Total Coliform bacteria group that is only available in the intestines of mammals and humans (The British Columbia groundwater association, 2007). The presence of Escherichia Coli in the groundwater represents an indicator for recent water contamination by fecal wastes. This mostly occurs within the catchment area of Tanour and Rasoun springs from wastewater leakage from domestic septic tanks, where all the surrounding villages are still unconnected to the sewage system.

Within this chapter, different variable parameters for water and pollutants travel time were monitored for a long time in both the Tanour and Rasoun springs, in order to have a better understanding about the characteristics of the karst aquifer of the Tanour and Rasoun springs, and its response to precipitation and pollution events. For that purpose, data from three sources were used:

- Automated online monitoring station in Tanour spring. This station was installed by the Ministry of Water and Irrigation (MWI), Jordan, in cooperation with the Federal Institute for Geosciences and Natural Resources, Germany (BGR). The recorded raw data from this station were received via BGR-MWI, analysed and used here.

- Data from a multi-probe sensor installed in Rasoun spring in cooperation with the Federal Institute for Geosciences and Natural Resources, Germany (BGR).

- Groundwater samples from both Tanour and Rasoun springs for analysing major ions.

This chapter aims to (1) evaluate the water quality of Tanour and Rasoun springs, (2) study the response of the Tanour and Rasoun springs during pollution events, (3) use the measured potassium concentration in both the Tanour and Rasoun karst springs, as well as that in the 
untreated wastewater (olive mills and domestic wastewater), in order to quantify the leaked wastewater volume from both (a) the olive mills wastewater (in Tanour spring), and (b) the domestic septic tanks wastewater (in Rasoun spring), and finally to (4) determine the water travel time in both the Tanour and Rasoun karst springs by investigating their response to precipitation events by using long-term monitored parameters for travel time.

\subsection{Methodology}

\subsubsection{Sampling}

\subsubsection{Tanour and Rasoun spring water samples}

A sampling campaign was carried out for the Tanour and Rasoun springs during the time period between November 2014 and March 2015. In total, 115 water samples were collected from the Tanour spring, and 113 water samples from the Rasoun spring (almost on a daily basis). The springs water samples were filled into $10 \mathrm{ml}$ polyethylene (PE) bottles, and were preserved in cool conditions.

\subsubsection{Domestic and olive mills wastewater samples}

Within the catchment area, four liquid wastewater samples were collected from different septic tanks of houses (September 2015). Samples were filtered directly at the location using $0.2 \mu \mathrm{m}$ Ion Chromatography Acrodisc syringe filters, filled in $10 \mathrm{ml}$ polyethylene (PE) bottles, and stored at $4^{\circ} \mathrm{C}$ until analysis.

In addition, one wastewater sample was collected from one of the olive mills (November 2014) located in the catchment area. The sample was filled in a one-litre polyethylene (PE) bottle and was placed in the fridge.

\subsubsection{Automated telemetry data from Tanour and Rasoun springs}

Within the Tanour spring, two multi-parameters probes were installed by the Ministry of Water and Irrigation (MWI) and the Federal Institute for Geosciences and Natural Resources as follows: 
- A SEBA multi-parameter probe, type MPS-D8 (Figure 5-1, a) was used in order to monitor (hourly measurements) the spring discharge $\left(\mathrm{m}^{3} / \mathrm{h}\right.$, calculated based on the measured weir water level), turbidity values (NTU), electrical conductivity $(\mathrm{mS} / \mathrm{cm})$, water temperature $\left({ }^{\circ} \mathrm{C}\right)$, and oxygen saturation (\%) in addition to other parameters that will not be used here. Data received from this station covered the time period from 01/04/2014 until 01/04/2016, except for the spring discharge, which was until $19 / 11 / 2015$, due to some technical problems in the spring discharge probe. The recorded values were stored every hour in a UniLog data logger and transferred via GPRS to the SEBA company and the Ministry of Water and Irrigation (MWI) servers.

- A UV absorption measurement (2-beam technique), reagent-free SAC254 in accordance with DIN 38404 C3 HACH-Lange probes (Figure 5-1, b) was installed also in the Tanour spring and used in order to measure indirectly the total organic carbon (TOC, mg/l) in the spring water (measurements every 5 seconds). Data from this station for TOC covered the time period between 20/09/2013 and 25/08/2015. The recorded data were stored using an internal logger and were downloaded manually on a regular basis.

The In-situ TROLL 9500 multi-parameter probe (Figure 5-1, c) was installed in the Rasoun spring in cooperation with the Federal Institute for Geosciences and Natural Resources (BGR) for the time period between 09/09/2014 and 13/04/2015 (hourly basis measurements) in order to monitor the electrical conductivity (EC) $(\mu \mathrm{S} / \mathrm{cm})$, water temperature $\left({ }^{\circ} \mathrm{C}\right)$ and turbidity (NTU). The recorded values were stored using an internal logger, and were downloaded manually on a regular basis.

Data from these stations were received in a regular basis via BGR-MWI. Data were analyzed, processed, and used within this study. 


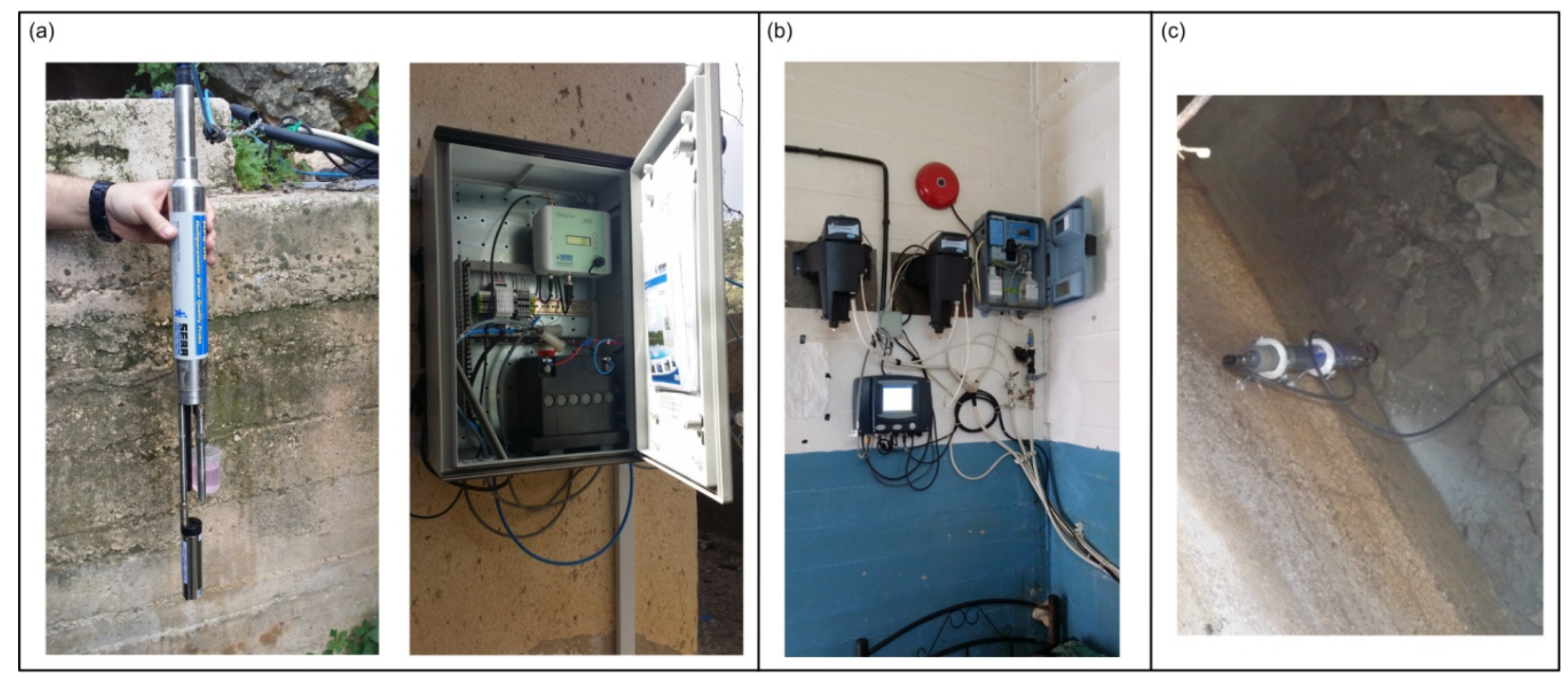

Figure 5-1: The automated multi-parameter probes that were installed in Tanour and Rasoun springs: (a) SEBA multi-parameter probe and data recorder, (b) HACH-lange multi-parameter probe recorder, and (c) In-situ TROLL multi-parameter probe (photo source: Ibraheem Hamdan).

\subsubsection{Laboratory analysis}

\subsubsection{Tanour and Rasoun spring water and domestic wastewater samples}

Major ions and bromide were analysed for Tanour and Rasoun spring water, and the wastewater samples from the septic tanks, using Ion Chromatography (IC) at the Geosciences Centre, GeorgAugust-University of Göttingen, Germany (Figure 5-2). The determination of anions was conducted on a DX-320 system (Dionex) with conductometric detection using the pre-column AG11-HC and the column AS11-HC. The separation was performed at $30{ }^{\circ} \mathrm{C}$ with $23 \mathrm{mMKOH}$ as eluent. For the analysis of inorganic cations, the DX-500 system (Dionex) with conductometric detection and the pre-column CG12 combined with a CS12 column was used. The separation was performed at $44^{\circ} \mathrm{C}$ using $20 \mathrm{mM}$ methanesulfonic acid as eluent.

Prior to the determination of anion concentration in the springs water $\left(\mathrm{Cl}^{-}, \mathrm{NO}_{3}^{2-}, \mathrm{SO}_{4}^{2-}, \mathrm{Br}^{-}\right)$, $1.5 \mathrm{ml}$ out of the $10 \mathrm{ml}$ water sample was filtrated using $0.2 \mu \mathrm{m}$ ion chromatography acrodisc syringe filters into a $1.5 \mathrm{ml}$ vial and analyzed in duplicate. For cation determination $\left(\mathrm{Ca}^{2+}\right.$, $\mathrm{Mg}^{2+}, \mathrm{K}^{+}, \mathrm{Na}^{+}$), the remainder of the $10 \mathrm{ml}$ water sample was spiked with $20 \mu \mathrm{l}$ Methanesulfonic acid $\left(\mathrm{CH}_{4} \mathrm{O}_{3} \mathrm{~S}\right)$. The acidic sample was left to react overnight and was then 
shaken for two hours on a shaker device. Then, $1.5 \mathrm{ml}$ was filtrated using $0.2 \mu \mathrm{m}$ ion chromatography acrodisc syringe filters into a $1.5 \mathrm{ml}$ vial, and analyzed in duplicate.

The domestic wastewater samples were analysed directly using ion chromatography for major ions, where samples were already filtered in the collection location. Samples had to be diluted for measuring because of the unknown background concentrations of these samples.

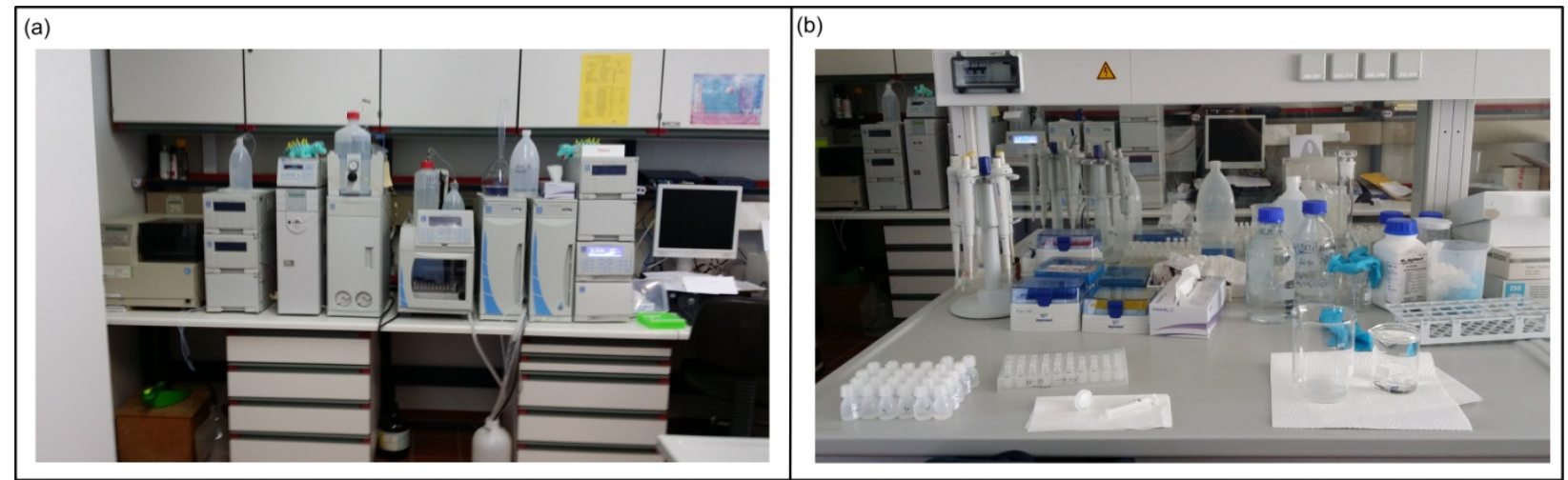

Figure 5-2: (a) Ion Chromatography instrument (IC), and (b) sample preparations for analysis (photo source: Ibraheem Hamdan).

\subsubsection{2. $\quad$ Olive mill wastewater sample}

The $\mathrm{pH}$ and electrical conductivity (EC) were measured using $\mathrm{pH}$ and EC electrodes. TOC (mg/l), total nitrogen (mg/l), and sodium $\left(\mathrm{Na}^{+}, \mathrm{mg} / \mathrm{l}\right)$ were analysed in Al Al-Bayt university, Jordan, using a WTW PhotoLab 6000 Spectrophotometer.

\subsection{Results and Discussion}

\subsubsection{Tanour and Rasoun spring water quality}

The water samples analysis in both the Tanour and Rasoun springs showed that the water is characterised as $\mathrm{Ca}^{2+}>\mathrm{Mg}^{2+}>\left(\mathrm{Na}^{+}+\mathrm{K}^{+}\right)$for cation sequence, and $\mathrm{HCO}_{3}^{-}>\mathrm{SO}_{4}^{2-}>\mathrm{Cl}^{-}$ for anion sequence. The high concentration of $\mathrm{Ca}^{2+}$ and $\mathrm{Mg}^{2+}$ reflects the water-rock interaction in the aquifer, where most parts of the catchment area are carbonate rocks. Table 5-1 presents the 
chemical analysis statistics for the analysed ions in the Tanour and Rasoun springs. Bicarbonate $\left(\mathrm{HCO}_{3}{ }^{-}\right)$was calculated manually based on the ionic balance.

Table 5-1: Chemical analysis statistics for Tanour and Rasoun springs.

\begin{tabular}{|c|c|c|c|c|c|c|}
\hline \multirow{2}{*}{ Ion } & \multicolumn{3}{|c|}{ Tanour spring (n= 115) } & \multicolumn{3}{c|}{ Rasoun spring (n= 113) } \\
\cline { 2 - 7 } & $\begin{array}{c}\text { Minimum } \\
(\mathbf{m g} / \mathbf{l})\end{array}$ & $\begin{array}{c}\text { Maximum } \\
(\mathbf{m g} / \mathbf{l})\end{array}$ & $\begin{array}{c}\text { Average } \pm \\
\text { Std. (mg/l) }\end{array}$ & $\begin{array}{c}\text { Minimum } \\
(\mathbf{m g} / \mathbf{l})\end{array}$ & $\begin{array}{c}\text { Maximum } \\
(\mathbf{m g} / \mathbf{l})\end{array}$ & $\begin{array}{c}\text { Average } \pm \\
\text { Std. (mg/l) }\end{array}$ \\
\hline $\mathrm{Ca}^{2+}$ & 97.0 & 140.8 & $105.7 \pm 5.5$ & 73.3 & 122.4 & $109 . \pm 8.1$ \\
\hline $\mathrm{Mg}^{2+}$ & 19.0 & 29.4 & $22.4 \pm 2.5$ & 10.6 & 25.7 & $19.5 \pm 3.9$ \\
\hline $\mathrm{Na}^{+}$ & 15.4 & 21.5 & $18.1 \pm 1.2$ & 12.6 & 19.5 & $16.6 \pm 2.1$ \\
\hline $\mathrm{K}^{+}$ & 3.0 & 71.3 & $6.9 \pm 8.6$ & 1.3 & 4.6 & $2.2 \pm 0.5$ \\
\hline $\mathrm{Cl}^{-}$ & 29.0 & 39.9 & $33.5 \pm 2.3$ & 27.6 & 44.2 & $34.7 \pm 3.7$ \\
\hline $\mathrm{SO}_{4}^{2-}$ & 7.6 & 21.8 & $17.4 \pm 3.0$ & 16.2 & 24.3 & $19.5 \pm 1.9$ \\
\hline $\mathrm{NO}_{3}^{-}$ & 1.7 & 45.4 & $34.0 \pm 8.8$ & 22.9 & 50.6 & $36.6 \pm 7.2$ \\
\hline $\mathrm{HCO}_{3}^{-}$ & 338.0 & 567.7 & $377.2 \pm 32.2$ & 229.4 & 412.0 & $356.5 \pm 38.5$ \\
\hline $\mathrm{Br}^{-}$ & 0.04 & 0.14 & $0.09 \pm 0.01$ & 0.05 & 0.18 & $0.10 \pm 0.02$ \\
\hline
\end{tabular}

Both the Tanour and Rasoun spring water samples results were plotted in the piper diagram (Figure 5-3) using AquaChem software version 2014.2 (C) Schlumberger). According to Langguth's (1966) classification for the water type (Table 5-2), both the Tanour and Rasoun spring water types are classified as type "a" which is characterised as "alkaline earth water with prevailing bicarbonate". 


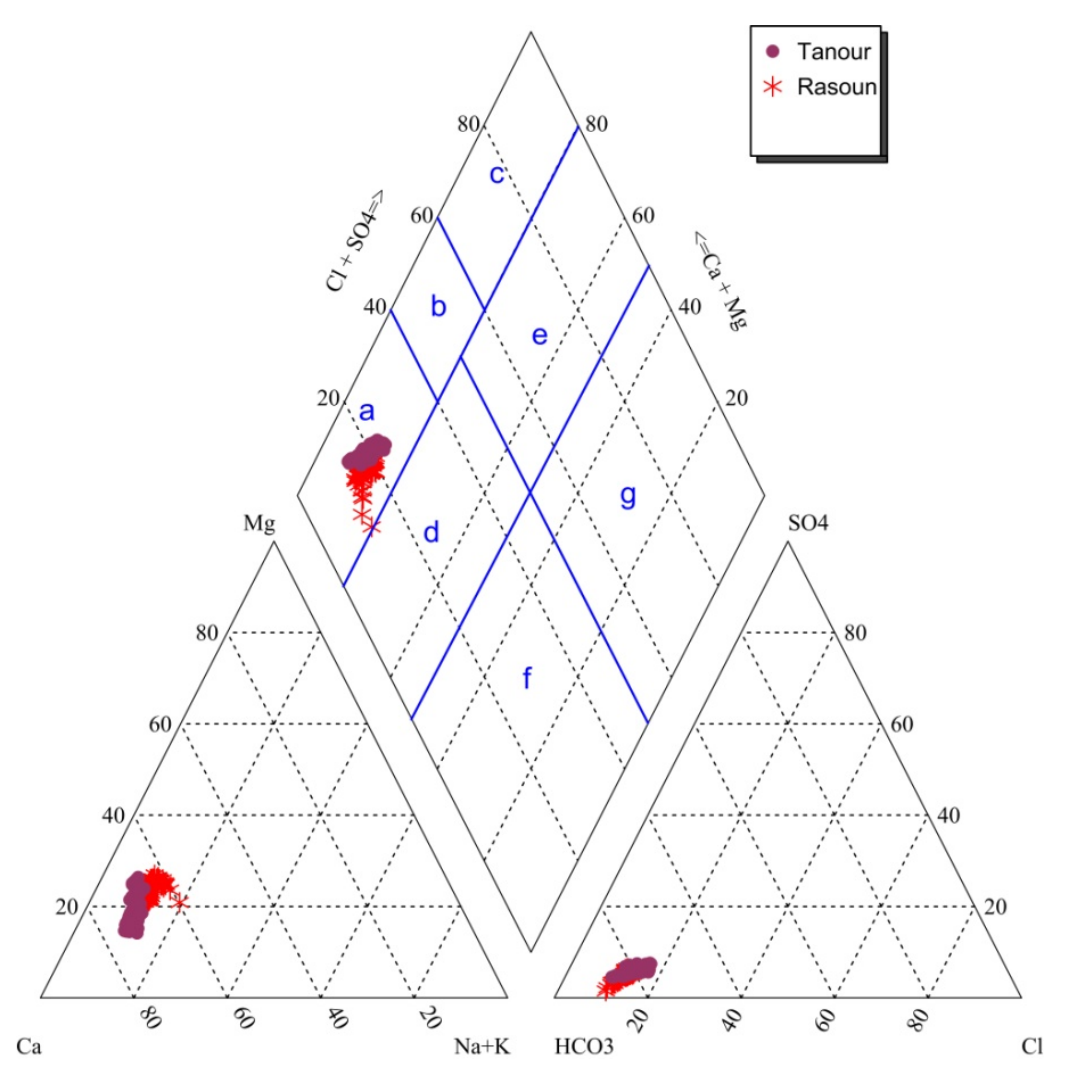

Figure 5-3: Piper diagram representing Tanour and Rasoun spring water types according to Langguth's (1966) classification.

Table 5-2: Classification of water types based on the piper diagram (Langguth 1966).

\begin{tabular}{|c|c|}
\hline \multicolumn{2}{|c|}{ Alkaline earth water } \\
\hline a & with prevailing bicarbonate \\
\hline b & with bicarbonate chloride \\
\hline c & with prevailing chloride \\
\hline \multicolumn{2}{|c|}{ Alkaline earth water increased portion of alkalies } \\
\hline d & with prevailing bicarbonate \\
\hline e & with prevailing chloride \\
\hline \multicolumn{2}{|c|}{ Alkaline water } \\
\hline f & with prevailing bicarbonate \\
\hline g & with prevailing chloride \\
\hline
\end{tabular}




\subsubsection{Karst aquifer response to pollution events}

\subsubsection{Pollution events in Tanour spring}

The Tanour spring suffers from two type of pollution: microbiological pollution from wastewater leakage from domestic septic tanks, in addition to the use of animal manure as fertiliser. Table 5-3 shows a selected historical analysis for Total Coliforms and Escherichia Coli in the Tanour spring between 2010-2015. The second pollution type is from the olive mills wastewater due to its leakage from the olive mills, or from the illegal dumping of these pollutants in the catchment area of the Tanour spring either in caves, wadis, large conduits, etc.

Table 5-3: Selected historical analysis for Total Coliforms (MPN/100 ml) and Escherichia Coli (MPN/100 ml) in the Tanour spring water during 2010-2015 (YWC-WAJ 2015a).

\begin{tabular}{|c|c|c|}
\hline Date & $\begin{array}{c}\text { Total Coliforms } \\
\text { (MPN/100ml) }\end{array}$ & $\begin{array}{c}\text { Escherichia Coli } \\
\text { (MPN/100ml) }\end{array}$ \\
\hline 07.04 .2010 & $>2419$ & 10 \\
\hline 14.04 .2010 & 1732 & $<1$ \\
\hline 22.01 .2011 & $>2419$ & $>2419$ \\
\hline 27.01 .2011 & 11000 & 230 \\
\hline 01.02 .2011 & $>2419$ & 3.1 \\
\hline 06.02 .2011 & $>2419$ & 116 \\
\hline 28.10 .2012 & $>2419$ & $>2419$ \\
\hline 29.10 .2012 & $>2419$ & $<1$ \\
\hline 21.11 .2012 & 32550 & $<1$ \\
\hline 08.12 .2012 & 920 & $<1$ \\
\hline 13.01 .2013 & 1413 & 102 \\
\hline 16.03 .2013 & 1413 & 2 \\
\hline 17.12 .2013 & 1299 & 43.9 \\
\hline 05.04 .2014 & 64.4 & 14.6 \\
\hline 04.11 .2014 & $>2419$ & $<1$ \\
\hline 29.11 .2014 & $>2419$ & 866.4 \\
\hline 30.11 .2014 & $>2419$ & 410 \\
\hline 27.12 .2014 & $>2419$ & 11 \\
\hline 06.01 .2015 & $>2419$ & $<1$ \\
\hline 11.01 .2015 & 1203 & 1 \\
\hline 14.01 .2015 & 866.4 & 1 \\
\hline
\end{tabular}

Pollution from the olive mills wastewater is the main problem for the Tanour spring, where it represents the main local water resource for the surrounding villages, and the long-term pollution 
period will be a major problem related to water supply. This comes in addition to the difficulty in cleaning the pipes and tank if the polluted water reaches them due to the changing spring water characteristics during the pollution event from the olive mills wastewater, where the water becomes oily and rich with organic compounds.

During the sampling period from the Tanour spring, two pollution events from the olive mills wastewater were measured and recorded. The first occurred on 03/11/2014, while the second occurred on 27/12/2014. During the two pollution events, water pumping from the Tanour spring was stopped for around 30 days during each event. For better understanding of the Tanour spring response for pollution events from the olive mills wastewater, data for the time period between November 2014 and March 2015 from the telemetry monitored parameters were used simultaneously with the manual sampling results for major ions, in order to give greater focus on the pollution events in the Tanour spring from the olive mills wastewater.

Both, the indirect TOC and oxygen saturation showed a high sensitivity to the pollution events that occurred in the Tanour spring from the olive mills wastewater. In addition, turbidity and electrical conductivity showed also a good agreement with indirect TOC and oxygen saturation during the pollution events. This clear and sensitive response for the pollution events from the olive mills is regarded to reflect the chemical composition of the olive mills wastewater, which is highly enriched in TOC and phenolic compounds, besides having high salinity and low pH. Table 5-4 presents the results of the analysed olive mills wastewater sample, and Figure 5-4 shows Tanour spring water during one of the pollution events from the olive mills, where it is oily and dark green or black in colour, because of the high concentration of organic compounds.

Table 5-4: Chemical analysis of the olive mills wastewater sample.

\begin{tabular}{|c|c|c|c|c|c|}
\hline $\begin{array}{c}\text { Measured } \\
\text { parameter }\end{array}$ & $\mathbf{p H}$ & $\begin{array}{c}\mathbf{E C} \\
(\mathbf{m S} / \mathbf{c m})\end{array}$ & $\begin{array}{c}\text { TOC } \\
(\mathbf{m g} / \mathbf{l})\end{array}$ & $\begin{array}{c}\text { Total Nitrogen } \\
(\mathbf{m g} / \mathbf{l})\end{array}$ & $\begin{array}{c}\mathbf{N a}^{+} \\
(\mathbf{m g} / \mathbf{l})\end{array}$ \\
\hline Value & 4.89 & 8.17 & 497 & $>150$ & 162 \\
\hline
\end{tabular}




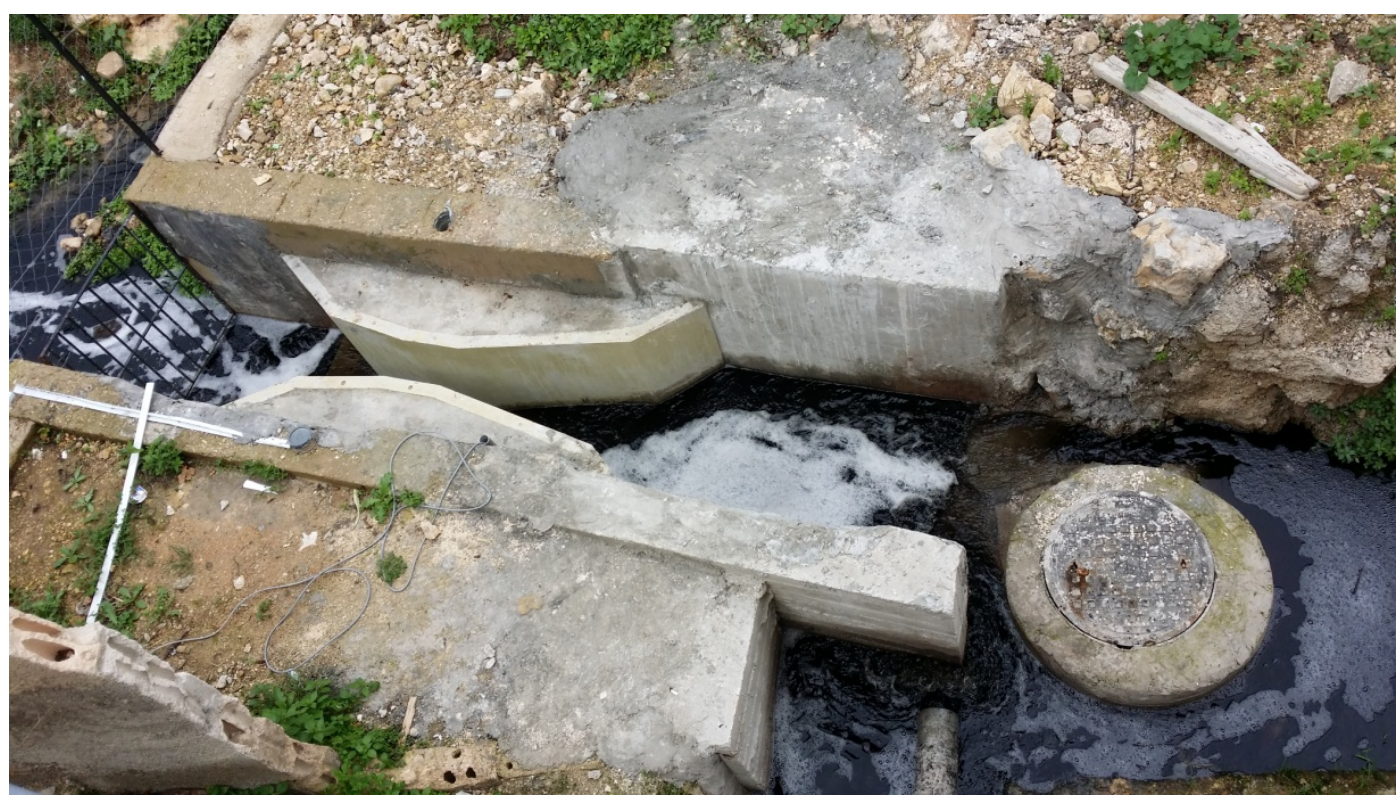

Figure 5-4: Tanour spring water during one of the pollution events from the olive mills wastewater. Water is oily and dark green or black in colour (photo source: Ibraheem Hamdan).

Based on the monitored parameters in the Tanour spring during the pollution events, Figure 5-5 shows its response during the two pollution events. The response of the Tanour spring during the two pollution events is different (Figure 5-5, points a and b); from the shape of the pollution peaks, the time needed to reach the peak of the pollution event, the reachable maximum value during each event, and the spring recovery time, can all be clearly seen.

During the first pollution event that started in 03/11/2014 (Figure 5-5, point a), both, the indirect TOC and oxygen saturation showed a high sensitivity to the pollutants, compared to the other parameters. The indirect TOC starts to increase and oxygen saturation starts to decrease slightly in the Tanour spring water 4 days before the pollution event. In addition, the concentration of the monitored parameters during the pollution event increased gradually until the maximum peaks were reached, and also decreased gradually, until the spring water returned back to normal. Based on the monitored indirect TOC and EC values, the first pollution event reached the maximum peak after 8 days (11/11/2014) (Figure 5-5, point a). In comparison, the second pollution event in the Tanour spring occurred on 27/12/2014 (Figure 5-5, point b), and had different behaviour and peak shape. The monitored parameters peaks shape during the second pollution event is very sharp: all the parameters responded very rapidly and at the same time, 
which reflects that a sudden influx of pollutants occurred, and that the pollutants reached the spring very rapidly and at high concentration. Based on the monitored parameters, the second pollution event reached the maximum peak just one day after the start of the pollution event $(28 / 12 / 2014)$.

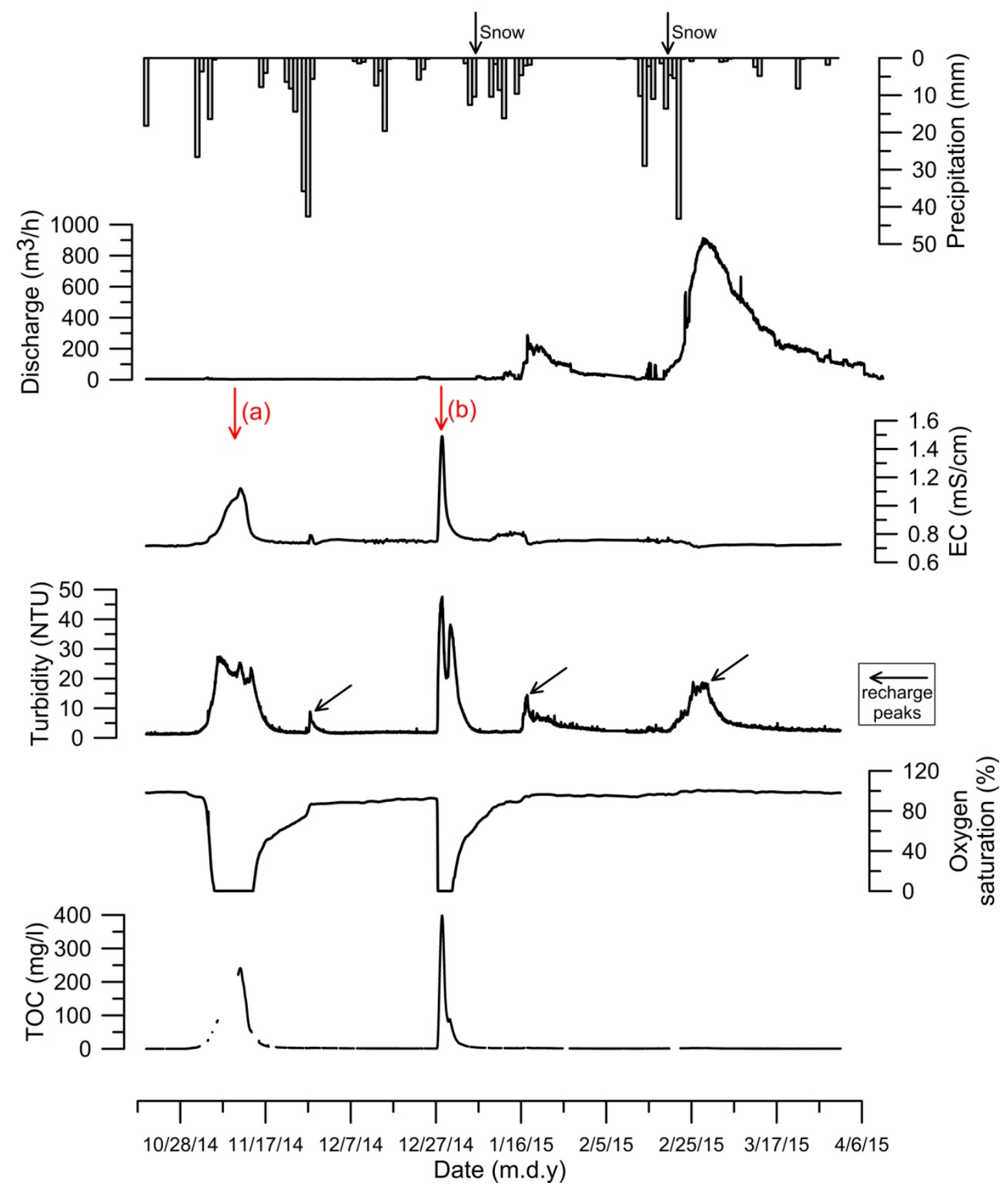

Figure 5-5: Variation in indirect TOC, oxygen saturation, turbidity, and EC values in the Tanour spring during the pollution events from the olive mills wastewater. 
The changes in turbidity values during the pollution events are due to the changes in the characteristics of the spring water during the pollution events from the olive mills wastewater, where the water is oily with dark green or black in colour, making it highly turbid.

Based on the monitored parameters during the two pollution events, it was noticed that during the first pollution event, both of the indirect TOC and EC values reached around $240 \mathrm{mg} / \mathrm{l}$ and $1.12 \mathrm{mS} / \mathrm{cm}$, respectively, compared to $400 \mathrm{mg} / \mathrm{l}$ and $1.49 \mathrm{mS} / \mathrm{cm}$ during the second pollution event, respectively. In addition, the oxygen saturation during the first pollution event took around 2 days (from 3-5/11/2014) to reach $0 \%$ value, while during the second pollution event it took just around 8 hours. Based on the analysed TOC and measured EC values from the raw olive mills wastewater (see Table 5-4), it was noticed that the TOC value in the raw olive mills wastewater was $497 \mathrm{mg} / \mathrm{l}$, compared to $240 \mathrm{mg} / \mathrm{l}$ and $400 \mathrm{mg} / \mathrm{l}$ during the first and the second pollution events in the Tanour spring water, respectively. The EC in the raw olive mills wastewater was around $8.2 \mathrm{mS} / \mathrm{cm}$, compared to $1.12 \mathrm{mS} / \mathrm{cm}$ and $1.49 \mathrm{mS} / \mathrm{cm}$ during the first and the second pollution events in the Tanour spring water, respectively. This high values of indirect TOC and EC during the second pollution event gives an indicator that the pollutants either leaked from a nearby place to the spring, or they were injected (illegal dumping) in a karst feature that has a direct connection to the spring, i.e. less dilution for the pollutants with aquifer water.

This difference in peak shapes between the two pollution events for the same parameter, the reached concentration, and the pollution event duration is regarded to reflect the difference in distances between the available olive mills within the catchment area and the Tanour spring, the leaked wastewater volume in each pollution event, and random illegal dumping of these pollutants within the catchment, either in wadis, large conduits, or caves. Predicting the source

and location of these pollutants is thus very difficult, especially as they do not follow the recharge events.

\subsubsection{Pollution events in Rasoun spring}

Based on the historical record for Rasoun spring water quality, the spring suffers mainly from microbiological pollution, where no pollution events from the olive mills wastewater were recorded. 
Table 5-5 shows selected historical analysis for Total Coliforms (mpn/100 ml) and Escherichia Coli (mpn/100 ml) in Rasoun spring water during the microbiological pollution events. The presence of Total Coliforms and Escherichia Coli in the spring water represents a good indicator about wastewater leakage from the septic tanks, where human and animal waste represents the main source of this type of bacteria. According to Table 5-5, there are microbiological pollution events that occurred in the Rasoun spring during the summer time also (not just during recharge events). This microbiological pollution occurs mainly due to the leakage of wastewater from domestic septic tanks, either from the illegal seepage of the wastewater instead of pumping of the septic tanks when full, or from technical problems that occur in the septic tank itself, like big cracks, or from illegal dumping of the wastewater by the tanks in wadis or in the karst features.

Table 5-5: Selected historical analysis for Total Coliforms (MPN/100 ml) and Escherichia Coli (MPN/100 ml) in the Rasoun spring water during 2009-2014 (YWC-WAJ 2015b).

\begin{tabular}{|c|c|c|}
\hline Date & $\begin{array}{c}\text { Total Coliforms } \\
\text { (MPN/100ml) }\end{array}$ & $\begin{array}{c}\text { Escherichia Coli } \\
\text { (MPN/100m) })\end{array}$ \\
\hline 01.11 .2009 & $>1600$ & 23 \\
\hline 11.02 .2012 & 178.5 & 5.2 \\
\hline 19.01 .2013 & 130.1 & 11.9 \\
\hline 29.04 .2013 & 26 & 13 \\
\hline 04.05 .2013 & 23 & 13 \\
\hline 01.06 .2013 & 920 & 4.5 \\
\hline 05.08 .2013 & 172.3 & 5.2 \\
\hline 02.11 .2013 & 220 & 9.2 \\
\hline 21.12 .2013 & 613.1 & 12.2 \\
\hline 28.12 .2013 & 816.4 & 4.1 \\
\hline 30.12 .2013 & $>2419.2$ & 1046.2 \\
\hline 04.01 .2014 & 198.9 & 15.8 \\
\hline 05.01 .2014 & 248.1 & 12.2 \\
\hline 06.01 .2014 & 214.3 & 35.9 \\
\hline 24.03 .2014 & 224.7 & 4.1 \\
\hline
\end{tabular}

\subsubsection{Using potassium $\left(\mathrm{K}^{+}\right)$concentration to quantify leaked wastewater volume towards Tanour and Rasoun springs}

Potassium in groundwater has mainly two different sources: (1) fertilisers and (2) wastewater. According to Jönsson et al. (1997) and Eiswirth and Hötzl (1997), human urine is an important source of potassium in wastewater, and increases of potassium and sulphate concentrations in 
groundwater are considered clear evidence for infiltration of wastewater. Nödler et al. (2011) found during the monitoring of the Leine River in Germany (receiving waters of wastewater treatment plant effluent) that there is a positive correlation between potassium concentration, originating from urine as a significant source within the wastewater treatment plants effluent, and 41 wastewater-related micro-contaminants. In addition, potassium concentration in the olive mills wastewater is very high (Doula et al., 2012; Ayoub et al., 2014), which make it as a good indicator about the leakage of wastewater from the olive mills towards groundwater.

Different methods have been applied in order to quantify the leaked wastewater volume in groundwater. Seiler et al. (1999) used caffeine and pharmaceuticals as an indicator of the wastewater contamination in wells. Hillebrand et al. (2012) used caffeine in order to quantify the untreated wastewater volume in karst systems. Schmidt et al. (2013) used the chloride mass balance method in order to quantify the long-term wastewater impacts on karst groundwater resources in a semi-arid environment.

During the sampling period, very clear potassium peaks were recorded in the Tanour and Rasoun springs. In the Tanour spring, the signal was connected to pollution events that occurred from the olive mills wastewater, while in the Rasoun spring, the potassium peaks were recorded simultaneously with the recharge events. Hillebrand et al. (2012) used caffeine concentration in order to quantify the untreated wastewater volume in the "Gallus" karst spring, Germany, by using the relationship between the measured caffeine concentration in the spring water, the daily water consumption per person, the spring discharge, and the caffeine load in untreated wastewater

Due to the lack of some data, like detailed daily water consumption from the olive mills, in addition to the potassium load per person and per olive mill, the direct calculation of wastewater volume in the Tanour (olive mills wastewater) and Rasoun (domestic wastewater) springs was applied directly by using the relationship between the potassium concentration in the springs and in the untreated wastewater (olive mills and domestic wastewater), and the spring discharge, as follows:

$$
c_{\text {spring }} * Q_{\text {spring }}=c_{\text {wastewater }} * Q_{\text {wastewater }}
$$

where $c_{\text {spring }}$ is the potassium concentration in spring water coming from the wastewater (the difference between the measured and the reference potassium concentration in the spring $\left.\left(\mathrm{g} / \mathrm{m}^{3}\right)\right)$, 146 
$Q_{\text {spring }}$ is the spring discharge $\left(\mathrm{m}^{3} / \mathrm{d}\right), c_{\text {wastewater }}$ is the measured potassium concentration in the undiluted wastewater $\left(\mathrm{g} / \mathrm{m}^{3}\right)$ (olive mills or domestic wastewater), and $Q_{\text {wastewater }}$ is the wastewater volume in the spring $\left(\mathrm{m}^{3} / \mathrm{d}\right)$.

\subsubsection{Estimation of domestic wastewater load (Rasoun spring)}

During the sampling period for the Rasoun spring between November 2014 and March 2015, clear and sensitive potassium peaks (comparing to the other monitored ions) were observed simultaneously with the recharge peaks that occurred after the precipitation events (based on the other monitored parameters in the Rasoun spring; Figure 5-6, points a, b, and c). During the first recharge event (Figure 5-6, point a), potassium concentration increased suddenly from $1.4 \mathrm{mg} / \mathrm{l}$ to reach $4.25 \mathrm{mg} / \mathrm{l}$, and then returned back to the range of $2 \mathrm{mg} / \mathrm{l}$. In the second recharge event, potassium increased again after the snowmelt to reach around $3.8 \mathrm{mg} / \mathrm{l}$ (Figure 5-6, point b). During the third recharge event, potassium had a different behaviour compared to the first and second events (Figure 5-6, point c): it increased due to the intensive rainfall, then decreased during the snow fall (19-21/02/2015), and then increased again because of the intensive rainfall straight after the snow fall, which accelerated the snowmelt process and increased the potassium concentration again. During the third recharge event, the potassium concentration reached around $3.1 \mathrm{mg} / \mathrm{l}$.

The Chloride-Bromide ( $\mathrm{Cl} / \mathrm{Br}$ ) mass ratio represents a good indicator about the degree of mixing between groundwater and wastewater (e.g. Davis et al. 1997, Vengosh and Pankratov 1998, Katz et al. 2011, McArthur 2012). According to Thomas (2000), the $\mathrm{Cl} / \mathrm{Br}$ mass ratio of 400 , representing a the limit between natural water and water influenced by human activities. During the sampling period, the calculated $\mathrm{Cl} / \mathrm{Br}$ mass ratio shows a wide range of values as between 220-590 (Figure 5-6), with $\mathrm{Cl}^{-}$concentration ranged between 27 to $44 \mathrm{mg} / \mathrm{l}$. Different other sources for chloride within the catchment area can affect the chloride concentration, like using sodium chloride $(\mathrm{NaCl})$ during the snow period as a de-icing salt on the roads to prevent freezing and accelerating the snowmelt process, compared to potassium, which showed greater stability and was a more highly sensitive signal than chloride. Therefore, potassium was used in order to quantify the leaked wastewater volume towards the Rasoun spring. 

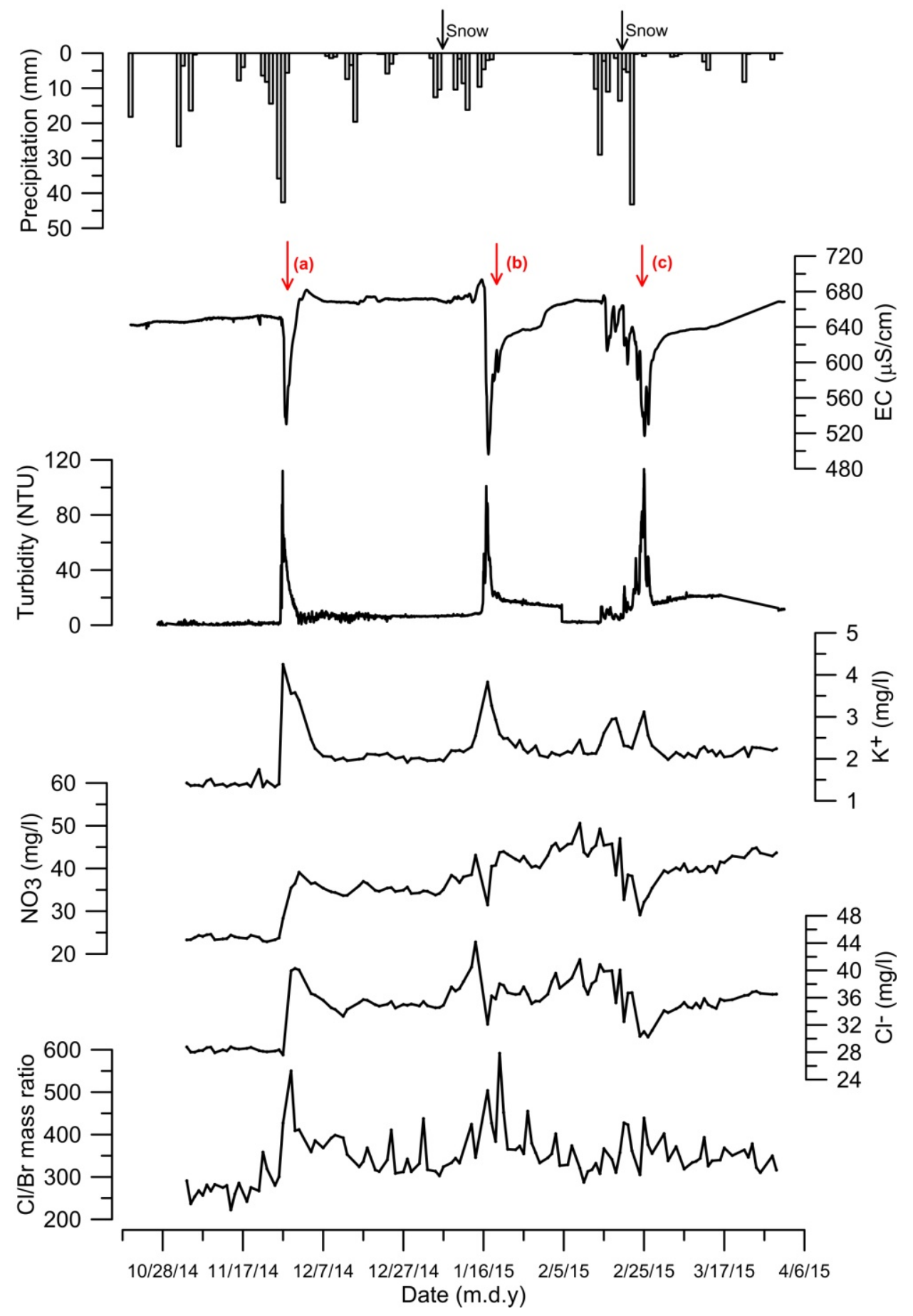

Figure 5-6: Combined chemo-hydrograph for Rasoun spring.

Based on the collected and analysed raw wastewater samples from the domestic septic tanks within the catchment area (Table 5-6), the average potassium concentration from the untreated domestic wastewater was calculated as $50.3 \mathrm{mg} / \mathrm{l}$. 
Table 5-6: Chemical analysis of wastewater samples collected from domestic septic tanks in different locations (September 2015).

\begin{tabular}{|c|c|c|c|c|c|c|c|}
\hline $\begin{array}{c}\text { Sample } \\
\text { number }\end{array}$ & $\begin{array}{c}\mathbf{C a}^{2+} \\
(\mathbf{m g} / \mathbf{l})\end{array}$ & $\begin{array}{c}\mathbf{N a}^{+} \\
(\mathbf{m g} / \mathbf{l})\end{array}$ & $\begin{array}{c}\mathbf{K}^{+} \\
(\mathbf{m g} / \mathbf{l})\end{array}$ & $\begin{array}{c}\mathbf{M g}^{2+} \\
\mathbf{( m g / l )}\end{array}$ & $\begin{array}{c}\mathbf{N O}_{\mathbf{3}}^{-} \\
(\mathbf{m g} / \mathbf{l})\end{array}$ & $\begin{array}{c}\mathbf{C l}^{-} \\
(\mathbf{m g} / \mathbf{l})\end{array}$ & $\begin{array}{c}\mathbf{N H}_{\mathbf{4}}^{+} \\
(\mathbf{m g} / \mathbf{l})\end{array}$ \\
\hline 1 & 52.2 & 225.0 & 49.1 & 26.8 & $<0,5$ & 334.0 & 229.0 \\
\hline 2 & 50.5 & 174.0 & 50.7 & 25.3 & $<0,5$ & 261.0 & 173.0 \\
\hline 3 & 54.9 & 247.0 & 68.6 & 23.2 & $<0,5$ & 369.0 & 249.0 \\
\hline 4 & 63.4 & 108.0 & 32.8 & 17.8 & $<0,5$ & 108.0 & 112.0 \\
\hline Average & $\mathbf{5 5 . 2}$ & $\mathbf{1 8 8 . 5}$ & $\mathbf{5 0 . 3}$ & $\mathbf{2 3 . 3}$ & N/A & $\mathbf{2 6 8 . 0}$ & $\mathbf{1 9 0 . 7}$ \\
\hline
\end{tabular}

A concentration of $1.9 \mathrm{mg} / \mathrm{l}$ was used in the Rasoun spring as the base-reference concentration in order to calculate the untreated wastewater volume from all the concentrations above this concentration using Equation (5.1). The average calculated wastewater volume in Rasoun spring from the domestic wastewater was therefore $9.8 \mathrm{~m}^{3} / \mathrm{d}$, while the minimum, maximum and median were $0.2 \mathrm{~m}^{3} / \mathrm{d}, 52.3 \mathrm{~m}^{3} / \mathrm{d}$, and $7.4 \mathrm{~m}^{3} / \mathrm{d}$, respectively. Figure $5-7$ represents the calculated domestic wastewater volume in Rasoun spring water.

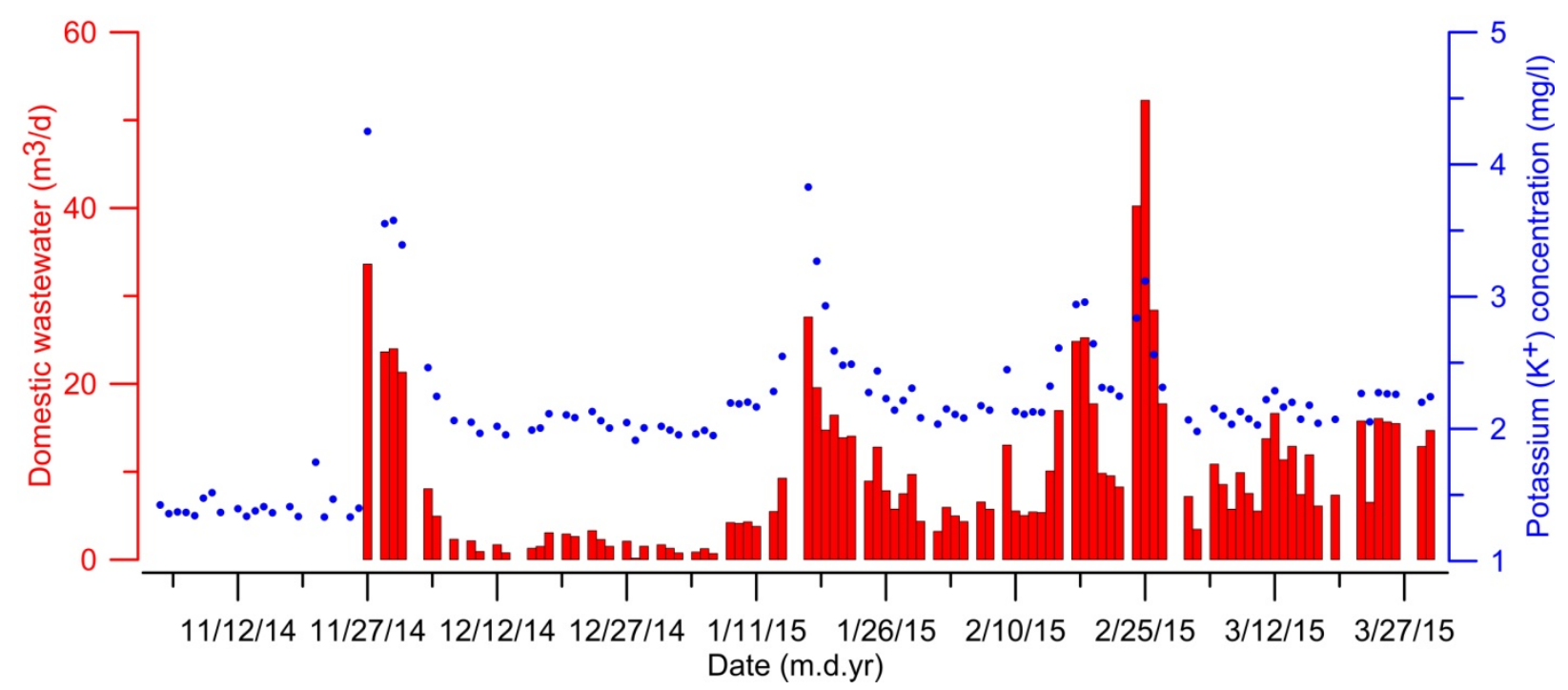

Figure 5-7: Calculated leaked domestic wastewater volume towards the Rasoun spring.

This calculated wastewater volume represents the leaked domestic wastewater load from houses located in the catchment area. All houses within the catchment are still unconnected to the sewage system. Any leakage from these septic tanks due to technical problems in the sealing of 
the septic tanks, illegal throughput of the wastewater instead of pumping it, illegal dumping of the pumped wastewater by tanks in wadis or in karst features, or the overflow of the septic tanks due to intensive rainfall, will reach the spring directly, due to the rapid water flow in the karst aquifer within the catchment area.

\subsubsection{2. $\quad$ Estimation of olive mills wastewater load (Tanour spring)}

During the pollution events that occurred in the Tanour spring from the olive mills wastewater, the potassium concentration in the spring water showed a very clear, wide, and strong peaks (Figure 5-8, points a and b). The maximum measured potassium concentration during the pollution events was $71.3 \mathrm{mg} / \mathrm{l}$ and $50.2 \mathrm{mg} / \mathrm{l}$ for the first and the second pollution events, respectively. This high concentration of potassium in the spring during the pollution events is regarded to reflect the high concentration of potassium in the raw wastewater of the olive mills. 


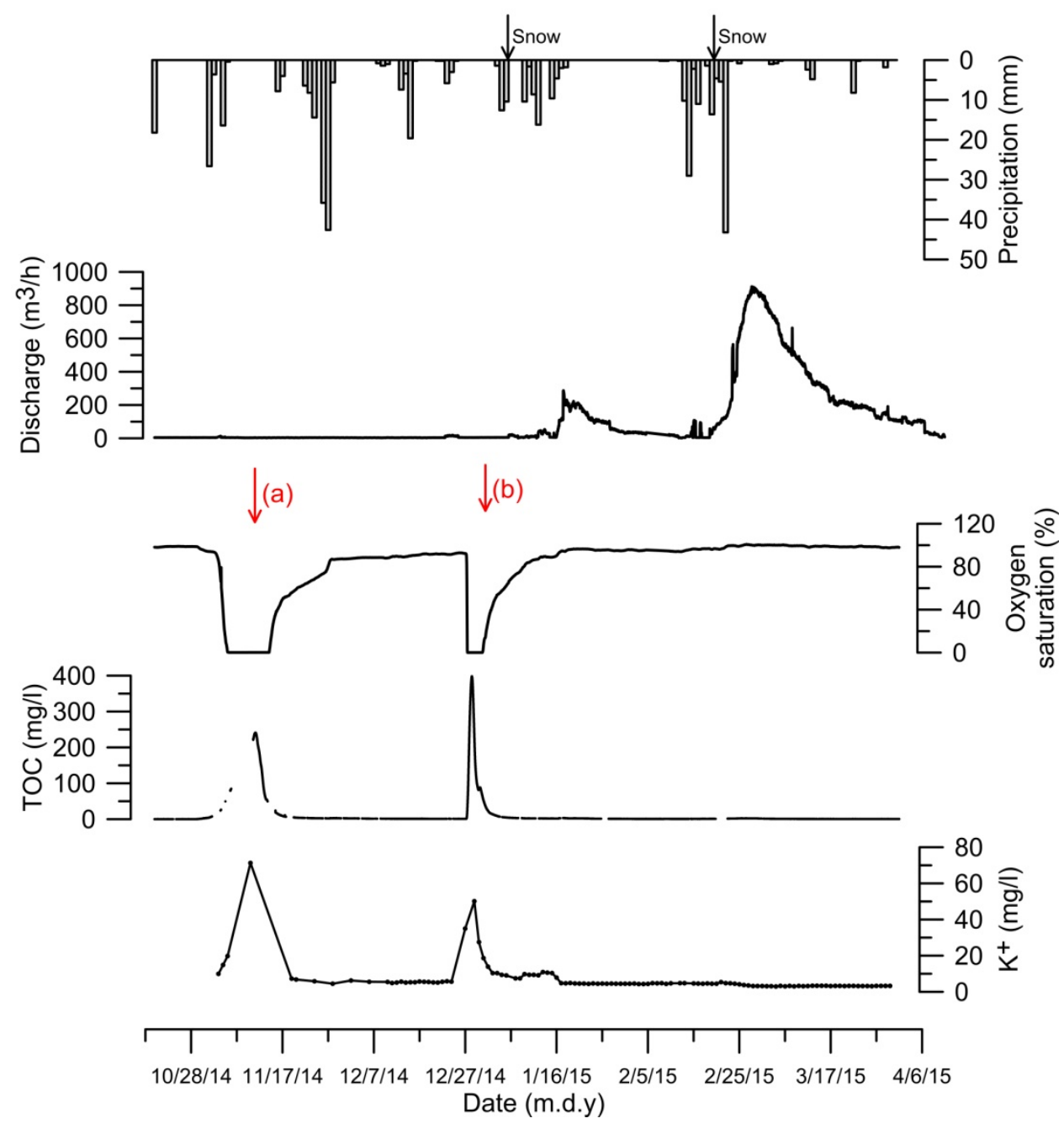

Figure 5-8: Change in potassium concentration in the Tanour spring during the pollution events from the olive mills wastewater, together with the other monitored parameters.

The same method (Equation 5.1) used for the Rasoun spring was applied to the Tanour spring, in order to estimate the leaked olive mills wastewater volume during the pollution events. For that purpose, a potassium concentration of $4 \mathrm{mg} / \mathrm{l}$ was used as a base-reference concentration in the Tanour spring. All concentrations above $4 \mathrm{mg} / \mathrm{l}$ were considered as pollution from the olive mills wastewater. Based on the previous studies about the chemical composition of the raw (undiluted) olive mills wastewater in Jordan (Rousan 2007, Massadeh and Modallal 2008, Ayoub et al. 2014), the average potassium concentration in the untreated olive mills wastewater was assumed as $1.95 \mathrm{~g} / \mathrm{l}$. Based on the daily discharge data for the Tanour spring, the measured potassium concentration in the Tanour spring water, and the potassium concentration in the raw olive mills 
wastewater itself, Figure 5-9 represents the calculated leaked wastewater volume towards Tanour spring from the olive mills wastewater. The average calculated wastewater volume in Tanour spring from the olive mills wastewater was $6.4 \mathrm{~m}^{3} / \mathrm{d}$, while the minimum, maximum and median were $0.7 \mathrm{~m}^{3} / \mathrm{d}, 93.6 \mathrm{~m}^{3} / \mathrm{d}$, and $2.0 \mathrm{~m}^{3} / \mathrm{d}$, respectively.

During the first pollution event in November 2014, calculation of the wastewater volume was applied on a non-continuous basis due to the lack of daily water samples from the spring, due to some obstacles in the sample collection process.

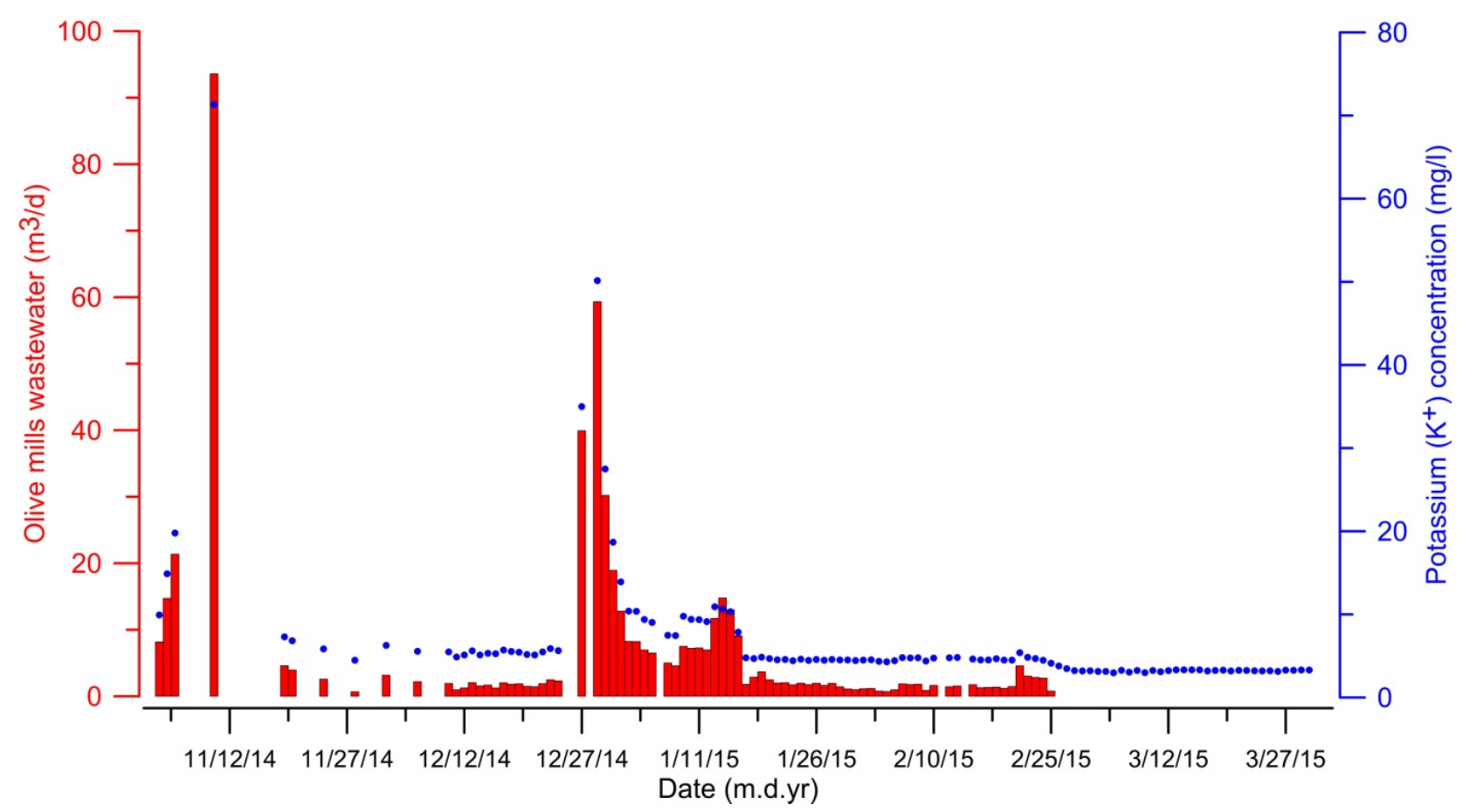

Figure 5-9: Calculated leaked olive mills wastewater volume towards the Tanour spring.

\subsubsection{Determination of water travel time in Tanour spring and investigation of its response to precipitation events}

For better understanding of the karst aquifer of the Tanour spring response to precipitation events, data from the automated online continuous measurement devices were used for water temperature $\left({ }^{\circ} \mathrm{C}\right)$, electrical conductivity $(\mathrm{mS} / \mathrm{cm})$, turbidity (NTU), and spring discharge $\left(\mathrm{m}^{3} / \mathrm{h}\right)$. These parameters were monitored on an hourly basis during April 2014 to April 2016, except for the spring discharge, which was stopped in November 2015. Based on the monitored parameters 
in the Tanour spring, Figure 5-10 represents the changes in the monitored parameters in the Tanour spring to precipitation events.

During winter 2014/2015, three recharge events were recorded (Figure 5-10, t1-t3). The first recharge event occurred after intensive rainfall from 22-28/11/2014 with total rainfall of 110 mm (MWI 2016), where around $90 \mathrm{~mm}$ fell between 26-28/11/2014. After this intensive precipitation event, the monitored parameters started to respond within two days (27/11/2014) from the start of the intensive rainfall, to reach a maximum on 28/11/2014 (three days from the start of the rain; Figure 5-10, t1). For the first snowfall event between 6-8/1/2015, a change in the monitored parameters from the snowmelt water and the rain after the snow (9-12/1/2015 and 15-18/1/2015, with total rainfall of $37 \mathrm{~mm}$ and $18 \mathrm{~mm}$, respectively: MWI 2016) was noticed on 16/1/2015 (eight days after the snow finished) to reach the maximum on 17/1/2015 (nine days after the snow finished) (Figure 5-10, t2). On the other hand, the third recharge event was recorded and observed directly after the second snow event between 19-21/02/2015, where the snowfall was preceded by intensive rainfall between 13-16/2/2015 (the rainfall amount was 50 mm: MWI 2016) and followed also by intensive rainfall on 22/2/2015 of 45 mm (MWI 2016) (Figure 5-10, t3). Therefore, the snow melted quickly and a direct response in the Tanour spring was observed. All monitored parameters reached the maximum on 26/2/2015 (five days after the snowfall event).

During the second recharge event (Figure 5-10, t2), the Tanour spring discharge increased to reach the maximum on 17/1/2015 (nine days after the snow finished) with a spring discharge of around $280 \mathrm{~m}^{3} / \mathrm{h}$ (not corrected for the pumping data). On the other hand, during the third recharge event (Figure 5-10, $\mathrm{t} 3$ ), the Tanour spring discharge increased to reach the maximum on 27/2/2015 (six days after the snow finished) with a spring discharge of around $900 \mathrm{~m}^{3} / \mathrm{h}$ (not corrected for the pumping data). The Tanour spring response and discharge amount are linked to precipitation amount (rain and snow), air temperature, and hence, the state of precipitation (Hamdan et al. 2016). These factors reflect the difference in the discharge amount in the Tanour spring between the second and third recharge events. Discharge measurement ceased in November 2015 due to technical problems in the weir water level probe. In addition, two pollution peaks from the olive mills wastewater were recorded and have been discussed previously in section 5.3.2. 
According to Martin and Dean (1999), there are three factors affecting the chemistry of karst water: (1) mixing degree between different water resources, (2) water-rock interaction and, (3) variations in the chemical composition of recharged water. During the second and third recharge events, magnesium $\left(\mathrm{Mg}^{2+}\right)$ concentration showed a good agreement simultaneously with the other monitored parameters in the Tanour spring. In the second recharge event (Figure 5-10, t2), the magnesium concentration decreased from around $25 \mathrm{mg} / \mathrm{l}$ to around $20 \mathrm{mg} / \mathrm{l}$ on 17/1/2015, while in the third recharge event, it decreased to around $19 \mathrm{mg} / \mathrm{l}$ on 27/2/2015 (Figure 5-10, t3). The decrease in magnesium concentration during the recharge events is regarded to reflect dilution in the aquifer water from the precipitation. 


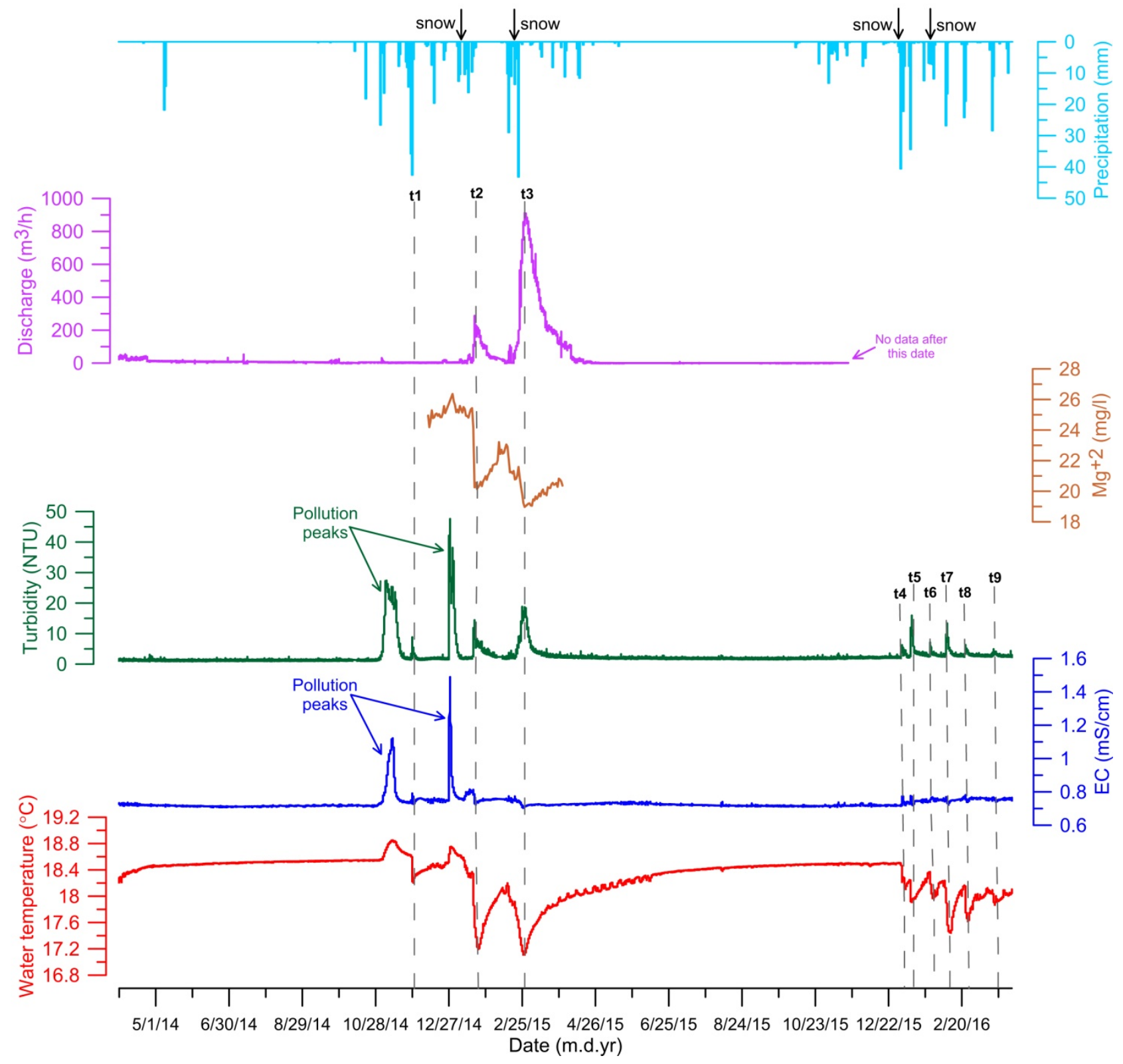

Figure 5-10: Tanour spring response to precipitation events based on the changes of water temperature, electrical conductivity, turbidity, spring discharge, and magnesium concentration.

During winter 2015/2016, six main recharge events were recorded in the Tanour spring based on the turbidity, water temperature and electrical conductivity measurements. Changes in electrical conductivity values during these recharge events are not so clear, so water temperature and turbidity will be used for further discussion. The recorded water temperature and turbidity peaks (Figure 5-10, t4-t9) showed that the Tanour spring response to precipitation events is very fast, 
where the turbidity values start increasing and water temperature start decreasing directly within 1-2 days from the start of the precipitation, to reach a maximum with an average of three days for turbidity and four days for water temperature.

Many other factors in addition to precipitation control the spring response and peak shapes during the recharge events, such as the type of precipitation (rain or snow), air temperature, and rainfall intensity per unit time. For example: the turbidity peaks t5 and t7 are double compared to the other peaks due to the high rainfall intensity, which increases the remobilisation of intrakarstic sediments due to the high water flow velocities. On the other hand, for peaks t4 and t6, the turbidity values increased a little due to the gradual melting of the snow.

\subsubsection{Determination of water travel time in Rasoun spring and investigation of its response to precipitation events}

During the monitoring time period in the Rasoun spring either from the In-situ TROLL 9500 multi-parameter probe data logger (hourly measurements) between September 2014 and April 2015 or for the analysed ions between November 2014 and March 2015, three recharge events were recorded in the Rasoun spring based on the water temperature, electrical conductivity, turbidity and magnesium $\left(\mathrm{Mg}^{2+}\right)$.Figure 5-11, points a, b and c, represents the recorded recharge events in the Rasoun spring and its response to the precipitation events. These three recharge events are connected to the same precipitation events that caused the recharge events $t 1$, $t 2$, and t3 in the Tanour spring. 


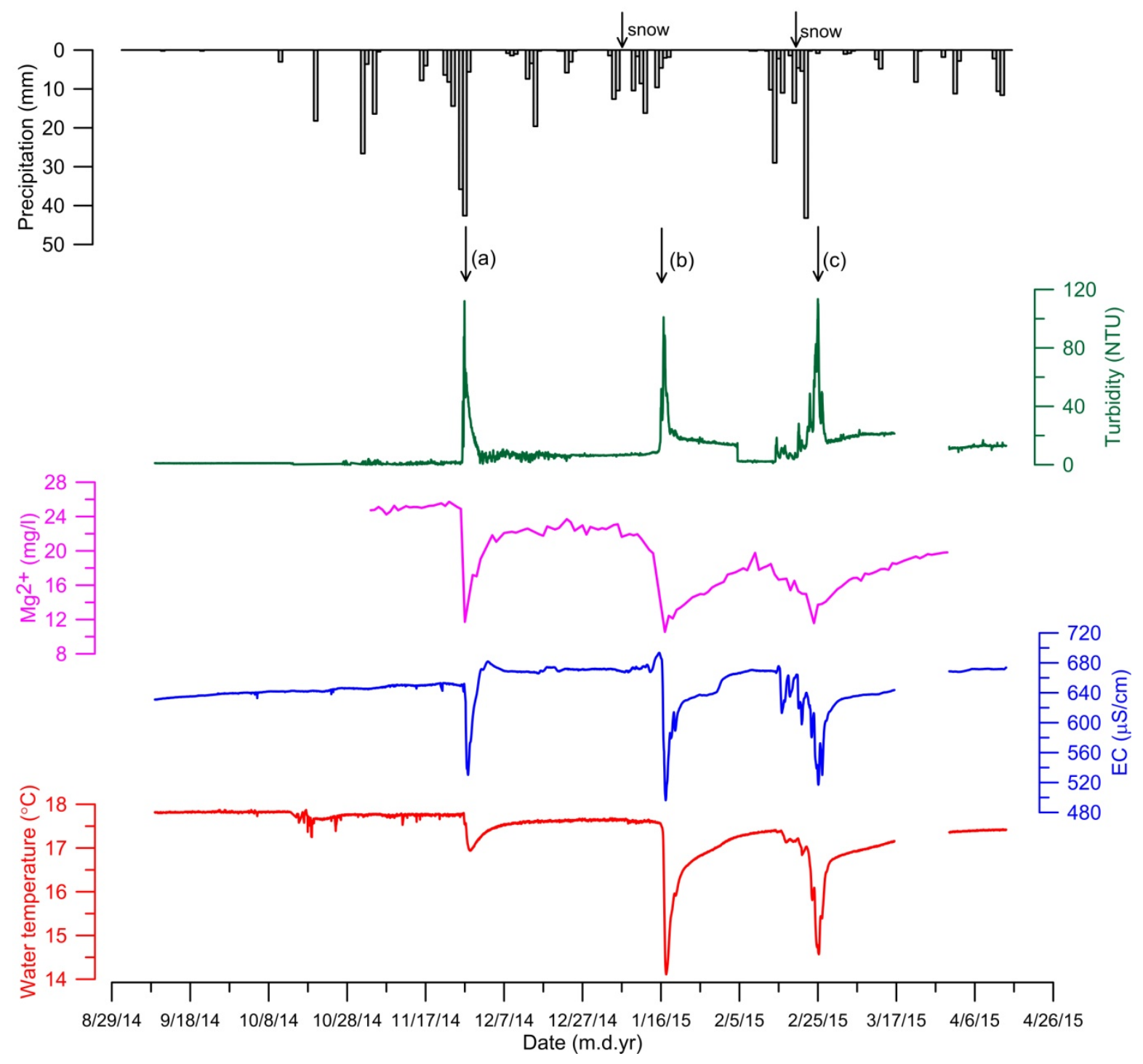

Figure 5-11: Rasoun spring response to precipitation events based on changes in turbidity, water temperature, electrical conductivity, and magnesium.

The recorded water temperature peaks from the Rasoun spring during the recharge events show a difference between the peak coming from the rainwater (Figure 5-11, point a) and those from snow (Figure 5-11, points b and c). The first recharge event in the Rasoun spring (Figure 5-11, point a) occurred due to intensive rainfall that occurred between 22/11/2014 and 28/11/2014. In total, around $110 \mathrm{~mm}$ rain fell, based on Ras Munif rainfall station (AH0003) (MWI 2016); around $90 \mathrm{~mm}$ fell between 26-28/11/2014. Water temperature, turbidity, and electrical conductivity have the same response time to this intensive rainfall event, where they start to 
change directly within the same day of the start of intensive rainfall (26/11/2014). Water temperature changed from around $17.8{ }^{\circ} \mathrm{C}$ to reach the minimum $16.9{ }^{\circ} \mathrm{C}$ after three days (28/11/2014) from the start of the rainfall. Turbidity started to increase and reached the maximum peak within two days of the start of the rainfall (27/11/2014), where it changed from around 2 NTU to reach around 110 NTU. Electrical conductivity reached the maximum peak also within two days from the start of the rainfall (27/11/2014). Electrical conductivity values decreased from around $650 \mu \mathrm{S} / \mathrm{cm}$ to $530 \mu \mathrm{S} / \mathrm{cm}$. The maximum water travel time for the first recharge event based on the monitored parameters was two days.

The second recorded recharge event (Figure 5-11, point b) occurred in the Rasoun spring after the snowfall between 6-8/1/2015, and the rainfall between 9-12/1/2015 and 15-18/1/2015 with total rainfall of $37 \mathrm{~mm}$ and $18 \mathrm{~mm}$, respectively (MWI 2016). Turbidity was the first parameter that showed a response to the snow melting and the rain after the snow. On 15/1/2015 (seven days after the snow stopped), turbidity started to increase from around 10 NTU to reach the maximum on 16/1/2015 (eight days after the snow finished) with around 100 NTU. On the other hand, both water temperature and electrical conductivity showed a response for the snow melting and the rain after the snow on 16/1/2015 (eight days after the snow stopped), to reach a maximum on 17/1/2015 (nine days after the snow stopped). The water temperature decreased from around $17.5^{\circ} \mathrm{C}$ to $14.1^{\circ} \mathrm{C}$, while electrical conductivity decreased from around $685 \mu \mathrm{S} / \mathrm{cm}$ to reach $495 \mu \mathrm{S} / \mathrm{cm}$. The maximum water travel time for the second recharge event, based on the monitored parameters, was calculated as nine days.

The third recharge event in the Rasoun spring was observed directly after an intensive rainfall event from 13-16/2/2015 (rainfall amount around $50 \mathrm{~mm}$; MWI 2016), followed by a second snowfall event between 19-21/02/2015 with some rainfall (around 25 mm; MWI 2016), and ended directly on 22/2/2015 with intensive rainfall of around $45 \mathrm{~mm}$ (MWI 2016). Due to the rainfall between 13-16/2/2015, small peaks and fluctuations were recorded from the monitored parameters values before the snowfall. All three parameters showed a direct response to the snowfall to reach the maximum on 25/2/2015 (four days after the snowfall event). During this recharge event, electrical conductivity decreased from around $660 \mu \mathrm{S} / \mathrm{cm}$ to $520 \mu \mathrm{S} / \mathrm{cm}$, turbidity increased from around $10 \mathrm{NTU}$ to $115 \mathrm{NTU}$, and water temperature decreased from around 17.1 ${ }^{\circ} \mathrm{C}$ to $14.6^{\circ} \mathrm{C}$. 
Figure 5-11 shows that the magnesium $\left(\mathrm{Mg}^{2+}\right)$ concentration parallels the trends of the other monitored parameters during the three recorded recharge events. During the recharge events, the magnesium concentration decreased in the Rasoun spring water from around $24 \mathrm{mg} / \mathrm{l}$ to around $12 \mathrm{mg} / \mathrm{l}$ (Figure 5-11, points a, b, and c). This decrease in magnesium concentration during the recharge events after the precipitation events is regarded to reflect the dilution of aquifer water from precipitation, where the karst aquifer of the Rasoun spring mainly forms from limestone.

\subsection{Conclusions}

During the monitoring period in the Tanour spring, both of the indirect TOC and oxygen saturation are considered as sensitive parameters for the pollution events that occurred in the Tanour spring from the olive mills wastewater. In addition, both turbidity and electrical conductivity showed a good response for the pollution events in the Tanour spring from the olive mills wastewater, in parallel with the indirect TOC and oxygen saturation. The high turbidity values during the pollution events from the olive mills wastewater is due to the changes in the spring water characteristics during the pollution events, where the water became oily and dark green or black in colour.

In both of the Tanour and Rasoun springs, a clear potassium signal was detected as an indicator for wastewater leakage towards the springs, either from the olive mills wastewater (detected in the Tanour spring) or from domestic wastewater (detected in the Rasoun spring). This signal was used in order to calculate the leaked wastewater volume from both sources based on the spring discharge, potassium concentration in the raw wastewater (olive mills and domestic watewater), and measured potassium concentration in both the springs.

Based on the different monitored parameters in the Tanour and Rasoun springs, both springs showed a very rapid response to precipitation events, which reflects the behaviour of the karst aquifer: rapid water flow and low storage capacity within the epikarst and karst features mean fast water travel time. The precipitation type (snow or rain) and intensity, duration, besides the air temperature during the precipitation events, all play a major role in determining the peak shapes, duration and the range of these peaks during the recharge events. 
During the monitoring program in the Tanour and Rasoun springs, the monitored parameters in both of the springs showed a high reliability, in order to study and monitor the response of the karst aquifer of the Tanour and Rasoun springs to precipitation events.

Based on the monitored parameters in the Tanour spring for the winter seasons 2014/2015 and 2015/2016, the Tanour spring showed a fast response to rainfall events (Figure 5-10; t1, t4 to t9), to reach the maximum peaks within 3-4 days. During the intensive snowfall events (Figure 5-10; t2 and t3), the Tanour spring has a different response due to the influence of other different factors like the thickness of snow, the air temperature, and the rainfall before or after the snow events, to reach the maximum peaks within nine and five days (from the end of the snow events) for the first and second snowfall event, respectively.

On the other hand, the maximum water travel time in the Rasoun spring for the first, second, and third recharge events (Figure 5-11; points a, b and c) that occurred in the winter season 2014/2015 is two, nine, and four days, respectively. These three recharge events are in parallel with the same three recharge events (t1, t2, and $\mathrm{t} 3$ ) that occurred in the Tanour spring.

The change in magnesium concentration in the Tanour and Rasoun springs after the precipitation events simultaneously with the other monitored parameters represents a good indicator of the water travel time in the aquifer. Changes in magnesium concentration during the recharge events are regarded to reflect the dilution effect of precipitation on the aquifer water.

The first three recharge events recorded for the Tanour and Rasoun springs (winter season 2014/2015) showed a wide range in the responses of the same parameter and same event between the Tanour and Rasoun springs. For example, the turbidity value in the Rasoun spring during these recharge events reached around 110 NTU, while in the Tanour spring, it was around 20 NTU. In addition, after the first snow event (second recharge event in both the Tanour and Rasoun springs), the Rasoun spring water temperature decreased by around $3.5^{\circ} \mathrm{C}$, while the Tanour spring water temperature decreased only by around $1^{\circ} \mathrm{C}$. This wide difference in the range between the Tanour and Rasoun springs is due to the differences in the catchment size between them, where the Rasoun spring catchment area is smaller than that of the Tanour spring, and is considered as a sub-catchment of the Tanour catchment. 


\subsection{References}

Ayoub S., Al-Absi K., Al-Shdiefat S., Al-Majali D., Hijazeen D. (2014) Effect of olive mill wastewater land-spreading on soil properties, olive tree performance and oil quality. Scientia Horticulturae. 175:160-166.

The British Columbia groundwater association (2007) Total, fecal and E.coli bacteria in groundwater. Water stewardship information series. Accessed: March 2016. Available from:

http://www.env.gov.bc.ca/wsd/plan_protect_sustain/groundwater/library/ground_fact_s heets/pdfs/coliform(020715)_fin2.pdf

Davis S., Whittemore D., Fabryka-Martin J. (1997) Uses of Chloride/Bromide ratios in studies of potable water. Ground Water. 36(2):338-350.

Doula M., Tinivella F., Ortego L., Kavvadias V., Sarris A., Theocharopoulos S., Sa'nchezMonedero M., Elaiopoulos K. (2012) Good practices for the agronomic use of olive mills wastes. "Strategies to improve and protect soil quality from the disposal of olive oil mill wastes in the Mediterranean” PROSODOL Project. LIFE07/ENV/GR/000280.

Eiswirth M., and Hötzl H. (1997) The impact of leaking sewers on urban groundwater. In: Chilton et al. (eds): Groundwater in the Urban Environment, p. 399-404.

Erb K., Ronk E., Koundinya V., Luczaj J. (2015) Groundwater quality changes in a karst aquifer of northeastern Wisconsin, USA: reduction of brown water incidence and bacterial contamination resulting from implementation of regional task force recommendations. Resources Journal. 4:655-672; doi:10.3390/resources4030655.

Hamdan I., Wiegand B., Toll M., Sauter M. (2016) Spring response to precipitation events using $\delta^{18} \mathrm{O}$ and $\delta^{2} \mathrm{H}$ in the Tanour catchment, NW Jordan. Isotopes in Environmental and Health Studies Journal; http://dx.doi.org/10.1080/10256016.2016.1159205.

Heinz B., Birk S., Liedl R., Geyer T., Straub K.L., Andresen J., Bester K., Kappler A. (2009) Water quality deterioration at a karst spring (Gallusquelle, Germany) due to combined sewer overflow: evidence of bacterial and micro-pollutant contamination. Environ Geol. 57:797-808; doi: 10.1007/s00254-008-1359-0. 
Hillebrand O., Nödler K., Licha T., Sauter M., Geyer T. (2012) Caffeine as an indicator for the quantification of untreated wastewater in karst systems. Water Research Journal. 46:395-402; doi:10.1016/j.watres.2011.11.003.

Jönsson H., Stenström T.-A., Svensson J., Sundin A. (1997) Source separated urine-nutrient and heavy metal content, water saving and faecal contamination. Wat. Sci. Tech. 35(9):145-152.

Kacaroglu F. (1999) Review of groundwater pollution and protection in karst areas. Water, Air, and Soil Pollution. 113: 337-356.

Katz B., Eberts S., Kauffman L. (2011) Using $\mathrm{Cl} / \mathrm{Br}$ ratios and other indicators to assess potential impacts on groundwater quality from septic systems: A review and examples from principal aquifers in the United States. Journal of Hydrology. 397:151-166; doi: doi:10.1016/j.jhydrol.2010.11.017.

Langguth, H. R. (1966) Die Grundwasserverhältnisse im Bereich des Velberter Sattels (Rheinisches Schiefergebirge). PhD dissertation. Düsseldorf, Germany.

Mahler B.J., Personne' J.-C., Lods G.F., Drogue C. (2000) Transport of free and particulateassociated becteria in karst. Journal of Hydrology. 238: 179-193.

Martin B. and Dean R. (1999) Temperature as a natural tracer of short residence times for groundwater in karst aquifers. In: Palmer A., Palmer M., Sasowsky I. (eds): Karst modeling. Conference proceedings. Virginia.

Massadeh M. and Modallal N. (2008) Ethanol production from olive mill wastewater (OMW) pretreated with Pleurotus sajor-caju. Energy and Fuels. 22:150-154.

McArthur J.M., Sikdar P.K., Hoque M.A., Ghosal U. (2012) Waste-water impacts on groundwater: $\mathrm{Cl} / \mathrm{Br}$ ratios and implications for arsenic pollution of groundwater in the Bengal Basin and Red River Basin, Vietnam. Science of the Total Environment. 437:390-402; doi: http://dx.doi.org/10.1016/j.scitotenv.2012.07.068.

MWI (Ministry of Water and Irrigation) (2016) Daily rainfall data for Ras Munif station (AH0003) (soft copy). Water information system, national master plan directorate. Amman, Jordan (unpublished). 
Nödler K., Licha T., Fischer S., Wagner B., Sauter M. (2011) A case study on the correlation of micro-contaminants and potassium in the Leine river (Germany). Applied Geochemistry. 24:2172-2180; doi:10.1016/j.apgeochem.2011.08.00.

Pronk M., Goldscheider N., Zopfi J. (2006) Dynamics and interaction of organic carbon, turbidity and bacteria in a karst aquifer system. Hydrogeology Journal. 14(4):473-484.

Pronk M., Goldscheider N., Zopfi J., Zwahlen F. (2009) Percolation and particle transport in the unsaturated zone of a karst aquifer. Ground Water. 47(3):361-369; doi: 10.1111/j.1745-6584.2008.00509.x.

Rousan L. (2007) Farmers' perceptions and adoption of using olive-mill wastewater on Barley crops in Jordan. World journal of Agricultural Sciences. 3(3):280-284.

Schiperski F., Zirlewagen J., Hillebrand O., Licha T., Scheytt T. (2015a) Preliminary results on the dynamics of particles and their size distribution at a karst spring during a snowmelt event. Journal of Hydrology. 526:326-332.

Schiperski F., Zirlewagen J., Hillebrand O., Nödler K., Licha T., Scheytt T. (2015b) Relationship between organic micro pollutants and hydro-sedimentary processes at a karst spring in south-west Germany. Science of Total Environment. 532:360-367.

Schmidt S., Geyer T., Marei A., Guttman J., Sauter M. (2013) Quantification of long-term wastewater impacts on karst groundwater resources in a semi-arid environment by chloride mass balance methods. Journal of Hydrology. 502:177-190.

Seiler R., Zaugg S., Thomas J., Howcroft D. (1999) Caffeine and pharmaceuticals as indicators of wastewater contamination in wells. Ground Water. 37(3):405-410.

Thomas M. (2000) The effect of residential development on ground-water quality near Detroit, Michigan. Journal of the American Water Resources Association. 36(5):10231038.

Vengosh A. and Pankratov I. (1998) Chloride/Bromide and Chloride/Floride ratios of domestic sewage effluents and associated contaminated groundwater. Ground Water. 36(5):815-824. 
Yarmouk Water Company (YWC) and Water Authority of Jordan (WAJ) (2015a) Historical microbiological analysis data for Tanour spring during the time period between 2010 and 2015 ( soft copy data files). Amman, Jordan.

Yarmouk Water Company (YWC) and Water Authority of Jordan (WAJ) (2015b) Historical microbiological analysis data for Rasoun spring for the years between 2009 and 2014 (soft copy). Amman, Jordan.

Zwahlen F., Goldscheider N., Neale S. (2003) Introduction to vulnerability and risk mapping for the protection of carbonate (karst) aquifers. In: Zwahlen F. (eds): COST action 620vulnerability and risk mapping for the protection of carbonate (karst) aquifers. Final Report, p 1-5. 


\section{Chapter six: Conclusions, future perspectives and recommendations}




\subsection{Conclusions and future perspectives}

Karst aquifers are highly sensitive to contamination events. The heterogeneous hydrogeological characteristics and pathways in the karst system itself and the fast connections between the land surface and the ground water system allow a concentrated and rapid inflow. This makes groundwater quality issues within karst systems very complicated due to the short water-rock interaction process and the absence of several processes of natural attenuation in the karst aquifers, such as: filtration, adsorption and chemical or microbiological decay processes. For that purpose, the understanding of groundwater pathways and water movement within the karst aquifers in general and within the epikarst zone particularly, is fundamental to evaluate pollution risks from point and non-point pollution sources in karst aquifer systems.

Different approaches and methods were developed and applied within this study to identify the characteristics and the flow dynamics of the karst aquifer of Tanour and Rasoun springs through the development of a travel time based approach for karst aquifers. All the applied and developed methods and approaches were shown in Figure 1-6.

The integrated breakthrough signal obtained from using of stable isotopes of oxygen and hydrogen, the monitoring of multi qualitative and quantitative parameters using automated probes and data loggers, and the development of travel time physics-based vulnerability assessment method shows good agreement as an applicable methods to determine the water travel time in karst aquifers, and to investigate its response to precipitation and pollution events (Figure 6-1).

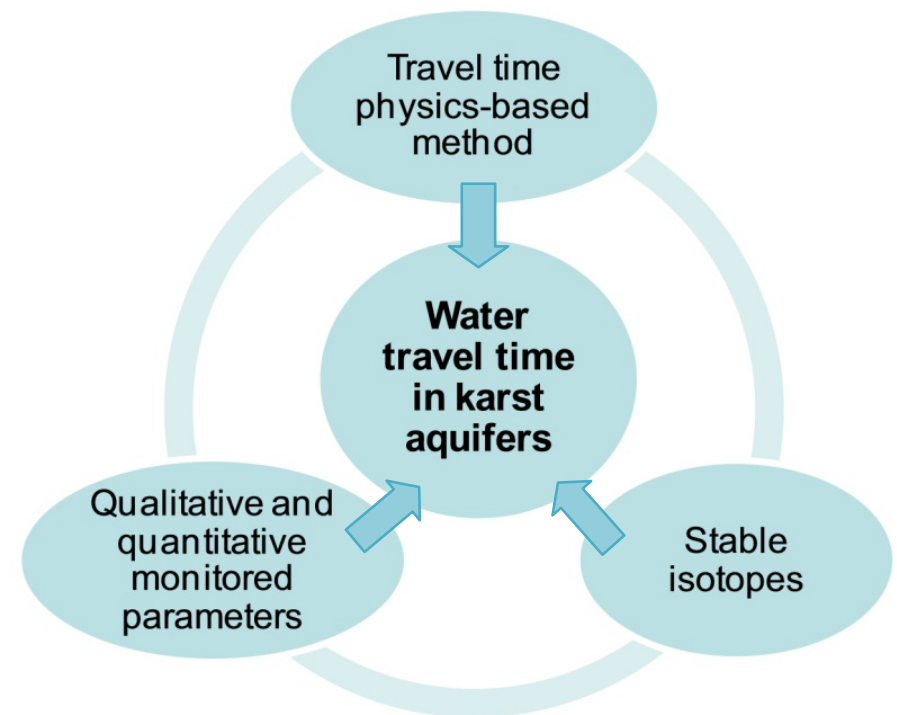

Figure 6-1: Compatibility between the applied methods related to the determination of water travel time in karst aquifers. 


\subsubsection{Water travel time and vulnerability assessment of the aquifer}

Using the stable isotopes of oxygen and hydrogen, water travel time physics-based method, and the monitored parameters in both of the springs were comparable indicating similar water travel time and response to precipitation events. The results gained from these methods revealed that Tanour and Rasoun springs respond rapidly to precipitation and pollution events; therefore, fast groundwater travel times through the epikarst and the saturated zone, rapid water transfer between karst features and direct connections between the land surface and the ground water system is implied.

Based on the monitored water temperature, turbidity and electrical conductivity in Tanour spring for the winter seasons 2014/2015 and 2015/2016 and in Rasoun spring for the winter season 2014/2015 (discussed in chapter five), both of the springs responded to precipitation events with an maximum water travel time of two to four days. An exception to this were during the intensive snowfall events that occurred in the winter season 2014/2015, where the maximum water travel time was around nine days for the first snowfall event (see Figure 5-10; $t 2$ and t3), and five days in Tanour spring and four days in Rasoun spring during the second snowfall event (see Figure 5-11; points b and c).

The results of the stable isotopes during the winter season 2014/2015 (discussed in chapter four) for the same two snowfall events showed that Tanour spring responded and reached the maximum within eleven and five days for the first and second snowfall event, respectively. While Rasoun spring responded and reached the maximum within nine and three days for the first and second snowfall event, respectively (see Figure 4-4 and Figure 4-5).

The applied travel time physics-based method (discussed in chapter three) is based mainly on the hydraulic characteristics of the karst aquifer system, compared to the COP and EPIK intrinsic vulnerability assessment methods which is mainly consider the natural properties and parameters of the aquifer itself (e.g. the geological setup and thickness of soil as a protective cover) which is reflecting the aquifer ability to attenuate the pollutants. The water travel time physics-based method showed that the water travel time within the epikarst zone, moving towards the streams as a final recharge point, are up to five days in approximately $97 \%$ of the catchment area. This result was in excellent agreement with the results from the stable isotopes and other monitored parameters.

The intersection between the COP intrinsic vulnerability assessment map and the water travel time map (Scenario c) showed that around 38\% of the catchment area is highly vulnerable with water travel time up to five days and around 32\% of the catchment area is moderately vulnerable with water travel time up to five days (see Table 3-12). This considerable percentage of highly and moderately vulnerable areas ( 70\%) with rapid water travel times through the epikarst (up to five days) reflects the high sensitivity of the karst aquifer of the Tanour and Rasoun springs catchment area to pollutants. 


\subsubsection{Karst aquifer response to pollution events}

Groundwater quality in the catchment area of Tanour and Rasoun springs is a big challenge. The fast response of the springs to precipitation events, the large percentage of very high to moderately vulnerable areas in the catchment and the fast water travel time through the epikarst to the streams as final recharge points reflects the past and current pollution events that occurred in both Tanour and Rasoun springs. In the case of pollution events from the olive mills wastewater, both the TOC and oxygen saturation showed a high sensitivity to the pollution events that occurred in the Tanour spring from this source. Prediction of pollutant travel time through the karst aquifer of Tanour and Rasoun springs is difficult when the pollution in the catchment area is considered a non-point source of pollution due to the illegal dumping of wastes in wadis, caves, conduits, etc., in addition to wastewater leakage from domestic septic tanks.

The developed method of using the potassium concentration in both of the springs and in the undiluted wastewater, in addition to the springs discharge displayed high reliability as an easy applicable method related to the quantification of the leaked wastewater volume towards Tanour and Rasoun springs from the olive mills and domestic wastewater. The use of lower time interval measurements of potassium concentrations and spring discharge provide a more precise calculation of the total leaked wastewater volume.

\subsubsection{Tracer tests (suggested injection locations)}

Delineation of the groundwater contribution zones (groundwater catchment) of Tanour and Rasoun springs and associated water flow velocities represents an essential step in the better understanding of the characteristics of this karst aquifer. Comprehensive tracer tests are needed to obtain this necessary information. Unfortunately, during this study, no tracer tests were conducted within the catchment area due to administrative issues related to licence requirements.

During the geological survey that was carried out in the catchment area between December 2014 and January 2015 in order to determine suitable injection locations for the tracer tests, three locations were identified as appropriate. The most suitable location was a dry valley directly adjacent to the Rasoun spring, where during the field survey it was noticed that spring outflow water disappeared around 100 to $150 \mathrm{~m}$ downstream of the spring, leaving the riverbed dry (Figure 6-2, a) . The second location was a dry valley bed located approximately $1.4 \mathrm{~km}$ from the Tanour spring (Figure 6-2, b). Finally, the third location was a doline located approximately 5 km southeast of the Tanour spring (Figure 6-2, c).

Sodium chloride ( $\mathrm{NaCl}$; common household salt) and the first location can be used as a typical tracer and appropriate injection location within the catchment area for various reasons. Sodium chloride will not colour the water like chemical tracers, it is inexpensive, is more acceptable to both the local community and the related authorities than chemical tracers and the outflow from the Rasoun spring will flush away the injected material (thus avoiding the need for any 
additional flushing water). About $300 \mathrm{~kg}$ of salt diluted in $1.5 \mathrm{~m}^{3}$ of water (20\% concentration) was proposed for a first test for the Rasoun spring outflow. The test should be conducted during the last part of the winter season (almost in March or early April).

A monitoring plan can be scheduled to measure water electrical conductivity at the Tanour and Beida springs at a high temporal resolution (at least one measurement per minute). Results will be verified by taking water samples every hour and analysing them for both sodium and chloride concentrations.

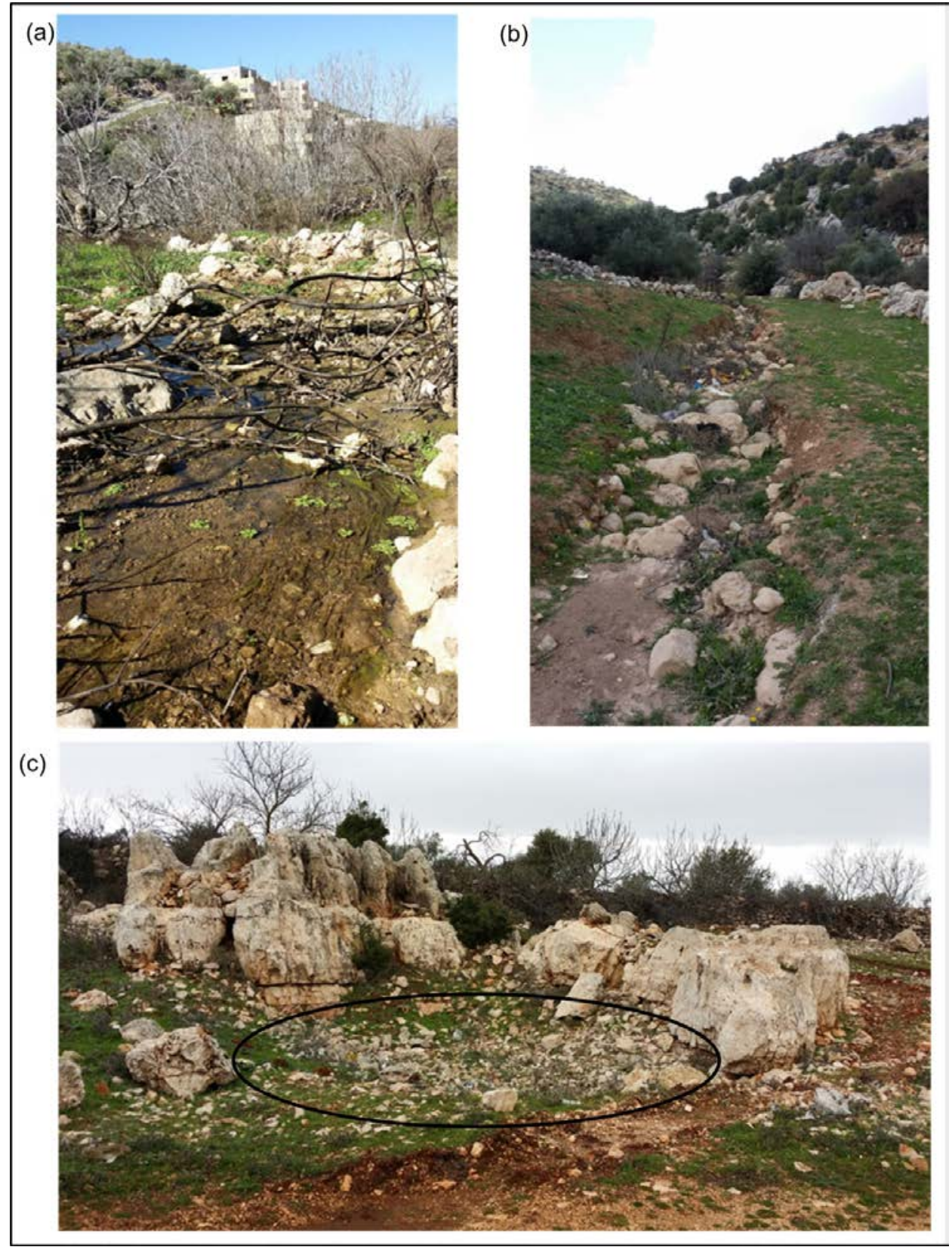

Figure 6-2: Suggested injection locations for tracer tests within the catchment area (photo source: Ibraheem Hamdan). 


\subsubsection{Hydrogeological parameters estimation}

The base flow recession curve method can provide highly reliable results regarding the estimation of the transmissivity values of the karst aquifer and subsequently estimation of hydraulic conductivity. Use of intensive long-term discharge measurements from both of the Tanour and Rasoun springs is required in order to obtain more precise values for transmissivity and hydraulic conductivity.

\subsection{Recommendations}

It is important that a data logger, like the one at the Tanour spring, should be installed at Rasoun spring for measuring the spring discharge, in addition to the continued monitoring at Tanour spring.

Producing higher resolution measurements of potassium concentrations in Tanour and Rasoun springs (e.g., hourly measurements rather than daily measurements) would provide more precise calculations about the leaked wastewater pollution load. For that, installing a potassium ion selective electrode and data logger at the Tanour and Rasoun springs is highly recommended.

> Regular and scheduled sampling of process water from the available olive oil mills within the catchment area during the working period is recommended to obtain an accurate average value for the potassium concentration in the undiluted olive mills wastewater. The potassium concentration in the olive mills wastewater varies based on process employed in each olive mill and so regular sampling will help produce more accurate results regarding leaked wastewater volume transported towards Tanour spring.

> Greater controls on the olive mills and the tanks in which they transport wastewater should be applied in order to prevent wastewater leakage and the illegal dumping of the wastewater in wadis, caves and large conduits.

Connecting villages located within the entire catchment with the sewage system should be a priority as more than $80 \%$ of the urban areas within the catchment area are located within areas where water travel time through the epikarst ranges between zero and two days. 
$>$ The high percentage of very high to moderately vulnerable areas, in addition to the fast water travel time through the aquifer, reflects the urgent need for decision makers to apply good land use management plans in the area and to perform a frequent monitoring program of the activities of the local olive mills and the illegal dumping of wastewater from both of the olive mills and domestic septic tanks. 


\section{Annexes}

\section{Annex 1: The applied calculations and conversions in the Landsat 8 satellite image to produce a final multi-band Landsat 8 satellite image}

Landsat 8 was developed as a collaboration between NASA and the U.S. Geological Survey (USGS). The Landsat 8 satellite payload consists of two science instruments: the Operational Land Imager (OLI) and the Thermal Infrared Sensor (TIRS). These two sensors provide seasonal coverage of the global landmass at a spatial resolution of 30 metres (visible, near infra-red (NIR) and shortwave infra-red (SWIR)); 100 metres (thermal); and 15 metres (panchromatic) (USGS 2014a).

Landsat 8 image No: LC81740382014124LGN00 (USGS 2014b) for the area launched in 04.05.2014 was downloaded (the cloud cover was chosen to be less than 10\%). Landsat 8 images include 11 bands (as a *.tif file); each band has a different wavelength and resolution (Table 7-1).

Table 7-1: Landsat 8 OLI and TIRS Bands ( $\mu m$ ) (USGS 2014a), (* OLI Bands, ** TIR Bands).

\begin{tabular}{|l|l|}
\hline \multicolumn{1}{|c|}{ Band Number and Resolution } & \multicolumn{1}{c|}{ Wavelength $(\boldsymbol{\mu m})$} \\
\hline Band 1* $^{*}$ - Coastal / Aerosol; 30 m & $0.435-0.451$ \\
\hline Band 2* - Blue; $30 \mathrm{~m}$ & $0.452-0.512$ \\
\hline Band 3* - Green; 30 m & $0.533-0.590$ \\
\hline Band 4* - Red; 30 m & $0.636-0.673$ \\
\hline Band 5* - NIR; 30 m & $0.851-0.879$ \\
\hline Band 6* - SWIR-1; 30 m & $1.566-1.651$ \\
\hline Band 7* - SWIR-2; 30 m & $2.107-2.294$ \\
\hline Band 8* - Pan; 15 m & $0.503-0.676$ \\
\hline Band 9* - Cirrus; 30 m & $1.363-1.384$ \\
\hline Band 10** - TIR-1; $100 \mathrm{~m}$ & $10.60-11.19$ \\
\hline Band 11** - TIR-2; $100 \mathrm{~m}$ & $11.50-12.51$ \\
\hline
\end{tabular}

The standard Landsat 8 products provided by the USGS EROS Center consist of quantized and calibrated scaled Digital Numbers (DN) 16-bit unsigned integer format, this DN representing multispectral image data acquired by both the Operational Land Imager (OLI) and Thermal Infrared Sensor (TIRS), and can be rescaled to the Top of Atmosphere (TOA) reflectance and/or radiance using radiometric rescaling coefficients.

In order to increase the satellite image resolution from $30 \mathrm{~m}$ to $15 \mathrm{~m}$, a spatial resolutionresolution merge techniques process was applied on the satellite image bands to convert them to $15 \mathrm{~m}$ resolution based on band 8-pan. This process was carried out using the ERDAS remote 
sensing software. According to the USGS (2014a), in order to produce a multi-band Landsat 8 Image for different uses, different types of calculations should be applied to each band. ArcGIS 10.3 was used in order to apply these calculations.

\section{- Conversion to TOA Radiance}

Both OLI and TIR bands can be converted to TOA spectral radiance by applying radiance rescaling factors (Table 7-2) in the following equation:

$$
\mathbf{L}_{\lambda}=\mathbf{M}_{\mathbf{L}} \mathbf{Q}_{\text {cal }}+\mathbf{A}_{\mathbf{L}}
$$

Where:

$\mathrm{L}_{\lambda}=$ TOA spectral radiance (Watts/( $\left.\left.\mathrm{m}^{2} * \operatorname{srad} * \mu \mathrm{m}\right)\right)$.

$\mathrm{M}_{\mathrm{L}}=$ Band-specific multiplicative rescaling factor from the metadata (Radiance mult band $\mathrm{x}$, where $\mathrm{x}$ is the band number).

$\mathrm{A}_{\mathrm{L}}=$ Band specific additive rescaling factor from the metadata (Radiance add band $\mathrm{x}$, where $\mathrm{x}$ is the band number).

$\mathrm{Q}_{\mathrm{cal}}=$ Quantized and calibrated standard product pixel values (DN).

For the study purposes, the DN to radiance conversion does not apply. Only the further steps were applied.

Table 7-2: Radiance rescaling factors (USGS 2014b (metadata file)).

\begin{tabular}{|l|l|l|l|}
\hline \multicolumn{2}{|c|}{ ML } & \multicolumn{2}{c|}{ AL } \\
\hline Radiance mult band 1 & 0.012350 & Radiance add band 1 & -61.74920 \\
\hline Radiance mult band 2 & 0.012646 & Radiance add band 2 & -63.23193 \\
\hline Radiance mult band 3 & 0.01654 & Radiance add band 3 & -58.26769 \\
\hline Radiance mult band 4 & 0.0098269 & Radiance add band 4 & -49.13460 \\
\hline Radiance mult band 5 & 0.0060136 & Radiance add band 5 & -30.06792 \\
\hline Radiance mult band 6 & 0.0014955 & Radiance add band 6 & -7.47762 \\
\hline Radiance mult band 7 & 0.00050407 & Radiance add band 7 & -2.52036 \\
\hline Radiance mult band 8 & 0.011121 & Radiance add band 8 & -55.60684 \\
\hline Radiance mult band 9 & 0.0023502 & Radiance add band 9 & -11.75123 \\
\hline Radiance mult band 10 & 0.00033420 & Radiance add band 10 & 0.10000 \\
\hline Radiance mult band 11 & 0.00033420 & Radiance add band 11 & 0.10000 \\
\hline
\end{tabular}




\section{- Conversion to TOA Reflectance}

Only OLI bands can be converted to TOA planetary reflectance using reflectance rescaling coefficients. The following equation is used to convert DN values to TOA reflectance data:

$$
\rho \lambda^{\prime}=\mathbf{M}_{\rho} \mathbf{Q}_{\text {cal }}+\mathbf{A}_{\rho}
$$

Where:

$\rho \lambda^{\prime}=$ TOA planetary reflectance.

$\mathrm{M}_{\rho}=$ Band-specific multiplicative rescaling factor from the metadata (Reflectance mult band $\mathrm{x}$, where $\mathrm{x}$ is the band number).

$\mathrm{A}_{\rho}=$ Band-specific additive rescaling factor from the metadata (Reflectance add band $\mathrm{x}$, where $\mathrm{x}$ is the band number).

$\mathrm{Q}_{\mathrm{cal}}=$ Quantized and calibrated standard product pixel values (DN).

Based on the metadata file provided with the Landsat 8 image (USGS 2014b), $M_{\rho}$ and $A_{\rho}$ are assumed to be 0.00002 and -0.100000 respectively.

\section{- Sun angle correction:}

After converting the DN to TOA reflectance, the TOA reflectance with a correction for the sun angle is calculated as follows:

$$
\rho \lambda=\frac{\rho \lambda^{\prime}}{\cos \left(\theta_{\mathrm{SZ})}\right)}=\frac{\rho \lambda^{\prime}}{\sin \left(\theta_{\mathrm{SE}}\right)}
$$

Where:

$\rho \lambda=$ TOA planetary reflectance corrected for sun angle.

$\rho \lambda^{\prime}=$ TOA planetary reflectance.

$\theta_{\mathrm{SE}}=$ Local sun elevation angle.

$\theta_{\mathrm{SZ}}=$ Local solar zenith angle; $\theta_{\mathrm{SZ}}=90^{\circ}-\theta_{\mathrm{SE}}$

The sun elevation angle provided with the Landsat 8 image metadata file is: $65.25747724^{\circ}$. 


\section{- Removing negative values}

By applying the previous calculations, some negative values have appeared that represent the outer border of the satellite image. In order to remove these values, the (Con) Map Algebra expression was applied (e.g.: Con(Band_1<0,0,Band_1)).

\section{- Composite Bands (final multi-band Landsat 8 image)}

After applying all the calculations and conversions on the Landsat 8 bands, the composite bands command was applied on bands 2-7 that represent the spectral wavelength (Figure 7-1).

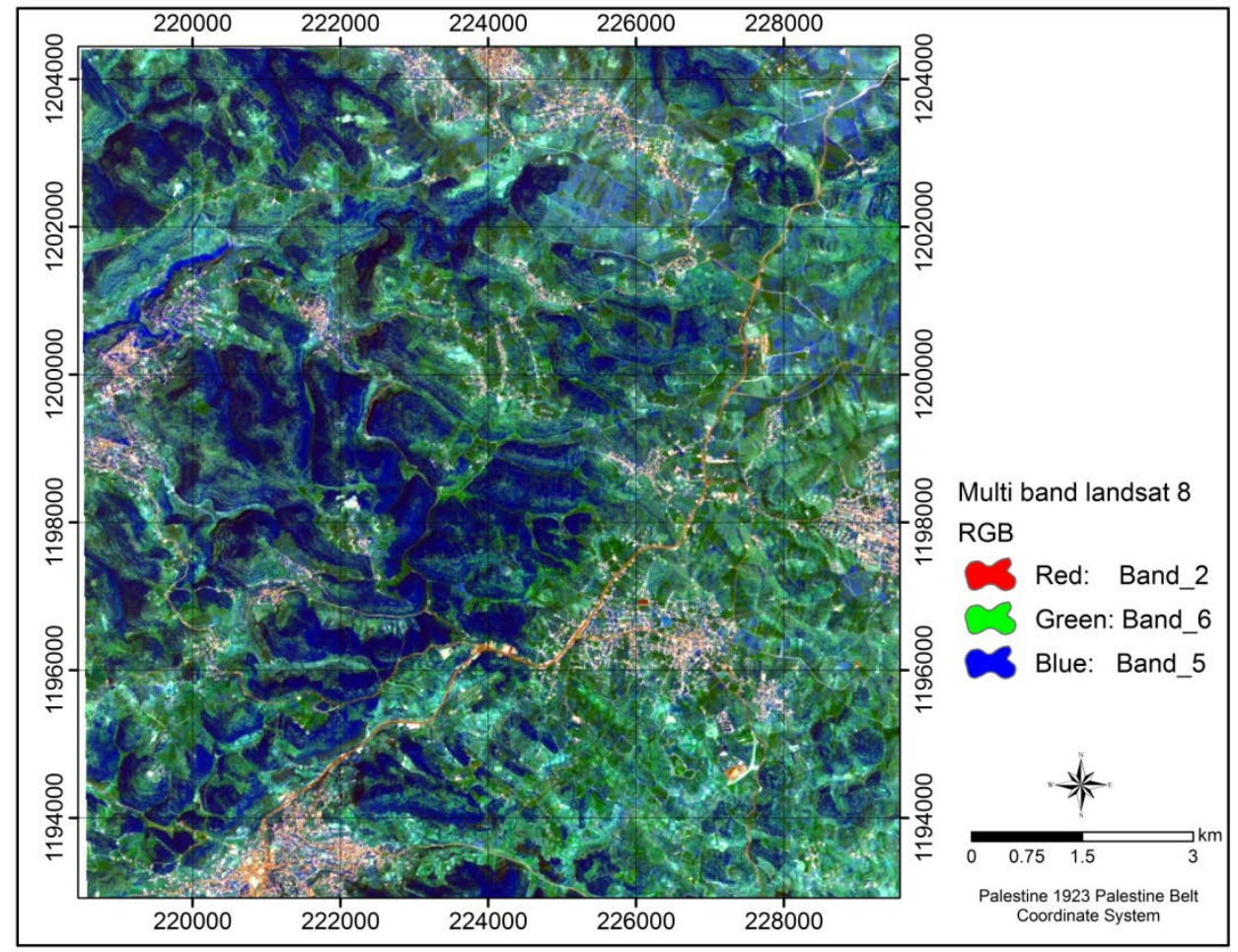

Figure 7-1: Final multi-band Landsat 8 satellite image 15 m resolution (extended area).

\section{References:}

USGS

Earth

Explorer

(2014a,

August),

http://landsat.usgs.gov/documents/Landsat8DataUsersHandbook.pdf.

USGS Earth Explorer (2014b, June) Landsat 8 satellite image, Landsat scene identifier No. LC81740382014124LGN00, http://earthexplorer.usgs.gov. 
Annex 2: The isotopic composition of $\delta^{18} \mathrm{O}$ and $\delta^{2} H$ in the rainwater samples collected by the IAEA from Ras Munif rain station for the time period between 1984 and 2004 (monthly cumulative rainwater samples).

\begin{tabular}{|c|c|c|c||c|c|c|c|}
\hline Date & $\boldsymbol{\delta}^{\mathbf{1 8}} \mathbf{O} \%$ & $\boldsymbol{\delta}^{\mathbf{2}} \mathbf{H} \%$ & $\mathbf{d}$-excess & Date & $\boldsymbol{\delta}^{\mathbf{1 8}} \mathbf{O} \%$ & $\boldsymbol{\delta}^{\mathbf{H}} \mathbf{\%}$ & $\mathbf{d - e x c e s s}$ \\
\hline Nov. 1987 & -5.9 & -15.87 & 31.33 & Mar. 1998 & -6.89 & -33.5 & 21.62 \\
\hline Feb. 1988 & -8.04 & -40.31 & 24.01 & Jan. 1999 & -6.93 & -29.9 & 25.54 \\
\hline Mar.1988 & -5.32 & -21.36 & 21.2 & Mar. 1999 & -4.88 & -19.5 & 19.54 \\
\hline Nov. 1988 & -6.87 & -33.3 & 21.66 & Nov. 1999 & -5.99 & -28.4 & 19.52 \\
\hline Dec. 1988 & -6.86 & -28.8 & 26.08 & Jan. 2000 & -6.31 & -28.2 & 22.28 \\
\hline Jan. 1989 & -7.16 & -32 & 25.28 & Feb. 2000 & -6.18 & -23.7 & 25.74 \\
\hline Feb. 1989 & -5.71 & -15.7 & 29.98 & Mar. 2000 & -6.51 & -27.6 & 24.48 \\
\hline Mar. 1989 & -7.38 & -41.1 & 17.94 & Oct. 2000 & -7.01 & -31 & 25.08 \\
\hline Dec. 1989 & -7.63 & -39.9 & 21.14 & Dec. 2000 & -6.42 & -28 & 23.36 \\
\hline Jan. 1990 & -7.59 & -36.5 & 24.22 & Jan. 2001 & -7.6 & -37 & 23.8 \\
\hline Feb. 1990 & -6.41 & -29.6 & 21.68 & Feb. 2001 & -6.86 & -30.9 & 23.98 \\
\hline Mar. 1990 & -6.42 & -27.7 & 23.66 & Oct. 2001 & -5.84 & -23.94 & 22.78 \\
\hline Apr. 1990 & -7.15 & -39.4 & 17.8 & Dec. 2001 & -6.52 & -25.73 & 26.43 \\
\hline Jan. 1991 & -7.93 & -38.9 & 24.54 & Jan. 2002 & -6.13 & -27.1 & 21.94 \\
\hline Feb. 1991 & -6.41 & -22.3 & 28.98 & Feb. 2002 & -7.17 & -34.7 & 22.66 \\
\hline Mar. 1991 & -7.99 & -40.8 & 23.12 & Mar. 2002 & -7.17 & -34.7 & 22.66 \\
\hline Apr. 1991 & -5.74 & -26.9 & 19.02 & Nov. 2002 & -5.98 & -21.79 & 26.05 \\
\hline Nov. 1991 & -8.19 & -40.4 & 25.12 & Dec. 2002 & -8.14 & -42.35 & 22.77 \\
\hline Dec. 1991 & -8.02 & -41.7 & 22.46 & Jan. 2003 & -7.58 & -35.06 & 25.58 \\
\hline Feb. 1992 & -6.51 & -24.2 & 27.88 & Feb. 2003 & -6.59 & -26.55 & 26.17 \\
\hline Dec. 1992 & -5.41 & -15.2 & 28.08 & Mar. 2003 & -6.64 & -31.82 & 21.3 \\
\hline Jan. 1993 & -7.46 & -35.9 & 23.78 & Nov. 2003 & -4.75 & -14.3 & 23.7 \\
\hline Feb. 1993 & -6.21 & -26.8 & 22.88 & Feb. 2004 & -5.27 & -21.94 & 20.22 \\
\hline Jan. 1998 & -6.86 & -27.98 & 26.9 & & & & \\
\hline
\end{tabular}




\section{List of publications within this study}

\section{Journal articles:}

1. Hamdan I., Wiegand B., Toll M., Sauter M. (2016) Spring response to precipitation events using $\delta^{18} \mathrm{O}$ and $\delta^{2} \mathrm{H}$ in the Tanour catchment, NW Jordan. Isotopes in Environmental and Health Studies. http://dx.doi.org/10.1080/10256016.2016.1159205.

2. Hamdan I., Margane A., Ptak T., Wiegand B., Sauter M. (under review, March 2016) Groundwater vulnerability assessment for the karst aquifer of Tanour and Rasoun springs catchment area (NW-Jordan) using COP and EPIK intrinsic methods. Under review in Environmental Earth Sciences Journal.

3. Hamdan I., Ptak T., Sauter M. , Wiegand B. (under review, June 2016) Travel time physics-based groundwater vulnerability assessment for non-point pollution sources in karst aquifers - An example from the Tanour and Rasoun spring catchment, NW-Jordan. Under review in Journal of Hydrology.

4. Hamdan I., Licha T., Toll M., Margane A., Sauter M. (under preparation) Quantification of wastewater pollution load using potassium concentrations in karst spring discharge.

\section{Conference proceedings:}

1. Hamdan I., Wiegand B., Ptak T., Licha T., Toll M., Margane A., Sauter M. (2015) Using stable isotopes and multi-spatial variable parameters in characterising the karstic aquifer of the Ajloun area, NW-Jordan - A case study of the Tanour and Rasoun springs. Geophysical research abstract. Vol. 17, EGU2015-1982, 2015. Poster presentation. EGU General Assembly 2015. April 12-17, 2015.

2. Hamdan I., Benhsinat M., Wagner B., Sauter M. (2016) Developing a geological 3D model for the Tanour and Rasoun spring catchment area using ArcGIS and GOCAD. Geophysical research abstract. Vol. 18, EGU2016-8010, 2016. Poster presentation. EGU General Assembly 2016. April 17-22, 2016.

3. Hamdan I., Wiegand B., Sauter M., Ptak T. (2016) Determination of groundwater travel time in a karst aquifer by stable water isotopes, Tanour and Rasoun spring (Jordan). Geophysical research abstract. Vol. 18, EGU2016-8282, 2016. Poster presentation. EGU General Assembly 2016. April 17-22, 2016.

4. Hamdan I., Sauter M., Margane A., Ptak T., Wiegand B. (2016) Groundwater vulnerability assessment for the karst aquifer of Tanour and Rasoun spring using EPIK, COP, and travel time methods. Geophysical research abstract. Vol. 18, EGU2016-8470, 2016. Poster presentation. EGU General Assembly 2016. April 17-22, 2016. 


\section{C.V: Ibraheem A. Hamdan}

\section{Personal data:}

Date of Birth: 17/July/1982.

Country of Birth: Jordan

Nationality: Jordanian

\section{Education:}

03/2013 - 08/2016

Ph.D. Student at Geosciences Centre, Department of Applied Geology, Georg-August-University Göttingen, Germany.

$10 / 2004-11 / 2006$

M.Sc. Water and Environmental Resources, Institute of Earth and Environmental Sciences, Al-Albayt University, Jordan.

$10 / 2000-07 / 2004$

B. Sc. Applied Geology and Environment, Institute of Earth and Environmental Sciences, Al-Albayt University, Jordan.

\section{Working experience:}

03/2007 - 05/2012

Federal Institute for Geosciences and Natural Resources (BGR), Jordan

Senior Hydrogeologist and GIS analyst within the following projects:

1- Groundwater Resources Management.

2- Water Aspects in Land-use Planning.

3- Managed Aquifer Recharge.

08/2004 - 10/2005

Institute of Earth and Environmental Sciences, Al-Albayt University, Jordan

Researcher Assistant (GIS) 